
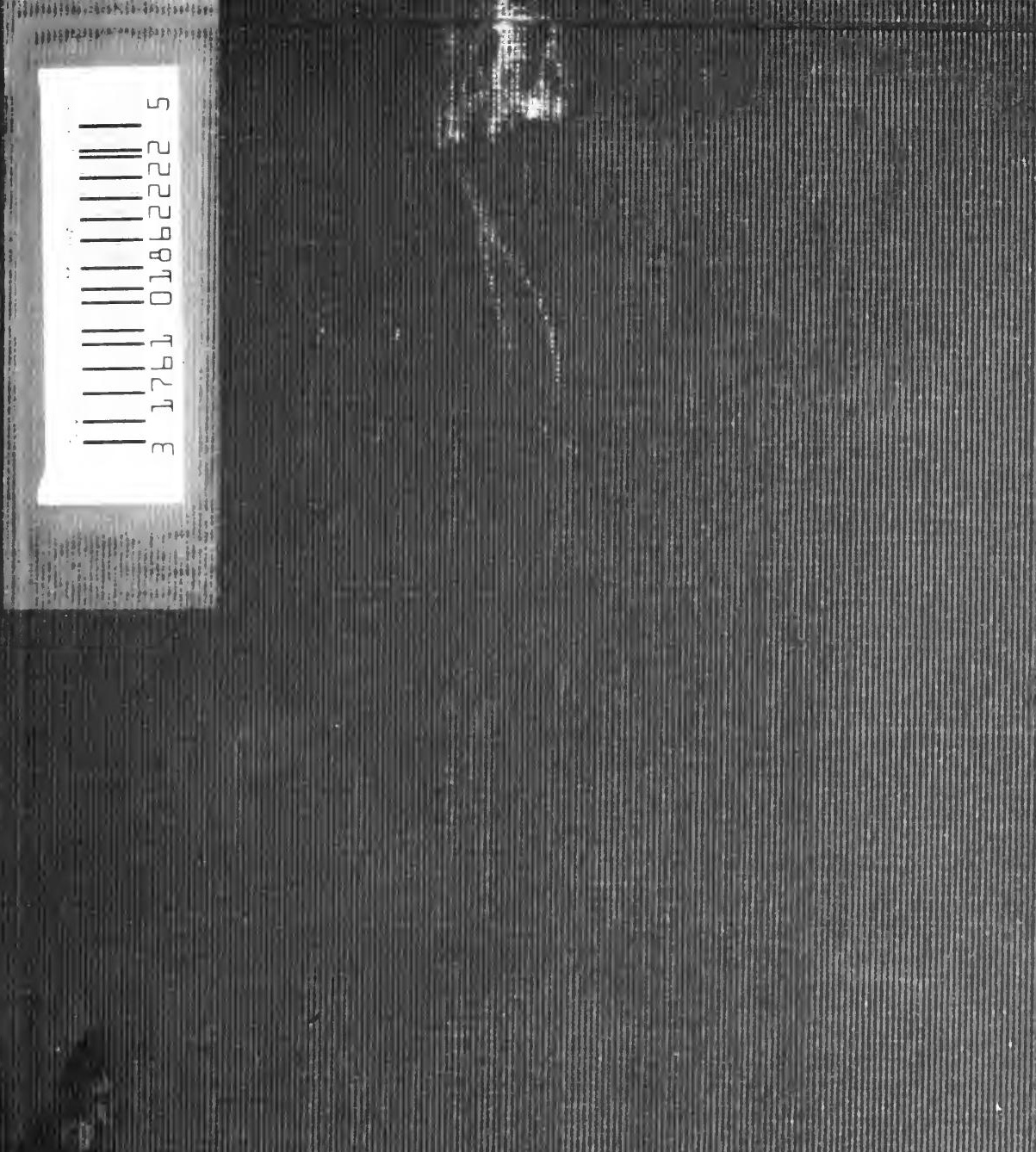
L.

Suraded Botilar

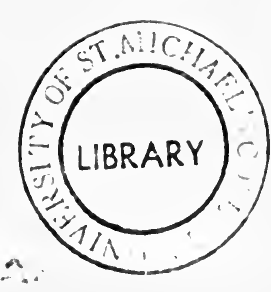



SOURCE BOOK IN ANCIENT PHILOSOPHY 



\section{SOURCE BOOK IN}

\section{ANCIENT PHILOSOPHY}

BY

CHARLES M. BAKEWELL

PROFESSOR OF PHILOSOPHY IN YALE UNIVERSITY

CHARLES SCRIBNER'S SONS

NEW YORK CHICAGO BOSTON 


\section{Copyrigat, 1907, BY}

\section{CHARLES SCRIBNER'S SONS}

Printed in the United States of America

Published September, 1907

$\mathbf{H}$
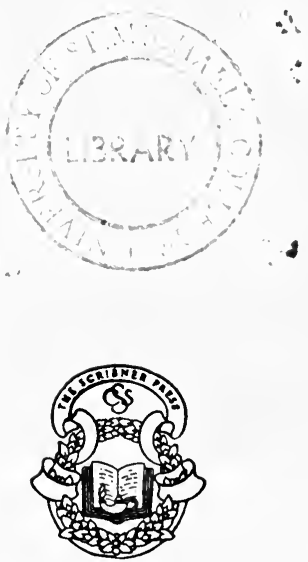


\section{P REFA CE}

EvERY one who has attempted to introduce students to the study of Philosophy by way of its history must have felt the need of having in compact form the most significant documents upon which the interpretations of that history are based, in order that it may be possible from the first to bring the student into direct contact with the sources, so far at least as that may be done through the medium of translations. The primary aim of this book is to supply this need. It is intended to serve either as a companion volume to any History of Philosophy that may be adopted as a text-book, or as a substitute for such a history where the instructor may prefer through his own lectures to give his own interpretation of this philosophical movement. It is hoped that the book may also, as a reference work, prove of value to students of philosophy generally, as well as to all who are interested in the development of ancient thought.

No attempt has been made to make an exhaustive Source Book. I have simply brought together the more significant passages from the earlier philosophers, beginning with Thales and reaching as far as Plotinus. The book includes most of the fragments of the earliest philosophers, together with the passages from the secondary sources which are most important in throwing light upon these fragments. In the case of the other philosophers it includes a number of brief extracts which may 
serve as texts to hang discussions on, and also some more extended passages selected with the view of bringing one directly into the spirit and method of the several philosophers represented. More space has been given to Plotinus than his relative importance would warrant. This, however, needs no apology. Plotinus is perhaps more frequently misrepresented in historical discussions than any other Greek philosopher. Here especially is it necessary to let the philosopher speak for himself. And, besides, Plotinus's works are comparatively inaccessible to English readers, whereas the extracts from Plato and Aristotle, from Lucretius and the later Stoics can be supplemented at will.

While most of these sources are already accessible in translation they are scattered through so many volumes, and are mixed with so much material that is chiefly of value to the advanced student whose historical interests have become highly specialized, as to be practically unavailable for use in connection with introductory courses.

My obligations to others are so numerous that it would be impossible to mention them all. In making the trauslations I have in each case had before me all of the translations already in the field, whether in English, German, French, or Latin, upon which I could lay my hands; and I have borrowed freely from most of them. In especial, however, I should like to acknowledge my indebtedness to Professors Diels, Burnet, and Fairbanks; and in the selection of passages I have taken many suggestions from the works of Ritter and Preller, Wallace, Jackson, and Adam.

I wish also to express my gratitude to Prof. G. H. Palmer for many valuable suggestions, and for the con- 
tribution of his translation of the Hymn of Cleanthes; and to Dr. B. A. G. Fuller for the selection and translation of the passages from Plotinus, and the passages from Plutarch in criticism of the Stoic theodicy.

My thanks are also due to Mr. T. W. Higginson for permission to quote from his translation of Epictetus, to Dr. W. T. Harris for permission to reprint from The Journal of Speculative Philosophy the translation of the fragments of Parmenides, made by the late Thomas Davidson, and to the Cambridge University Press, the Oxford University Press, Messrs. George Bell \& Sons, The Macmillan Company, and Little, Brown \& Company, for permission to use translations published by them. Special acknowledgments of borrowed translations are made in foot-notes. The only case where confusion is likely to arise is in the extracts from Plato. I assume responsibility myself for the translation of the Apology; the selections from the Republic are from the translation of Davies and Vaughan, and all the remaining Plato selections are from the latest edition of Jowett's work. 
3 


\section{CONTENTS}

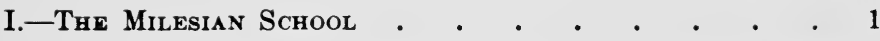

Thales: General standpoint of the early philosophers, and the opinions of Thales, 1. Anaximander: The "boundless" as first principle, 3. Scientific speculations, 5. Anaximenes: His opinions, 7.

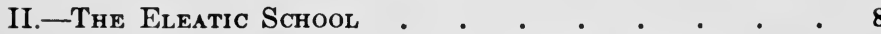

Xenophanes: The fragments, 8. An illustration of Xenophanes's scientific reasoning, 10. Parmenides: The fragments of his poem "On Nature," 11. Plato and Aristotle on Eleatic philosophy, 20. Zeno: The puzzles of composition and division, 22. Space not a real thing. 23. The puzzles of motion, 24. The purpose of Zeno's arguments as reported by Plato, 25.

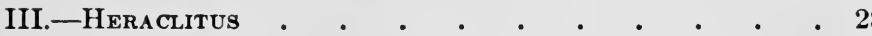

The fragments, 28.

IV.-The Pythagorean Philosophy . . . . . . 36

The number philosophy of the Pythagoreans, 36. The Pythagorean "Golden Words," 40.

V.-EMPEDOCLES

The fragments, 43 . Secondary sources, 46 .

VI.-ANaxagoras

The fragments, 49. Secondary sources, 53. Some of Aristotle's comments on Anaxagoras, 55.

VII.-The Aтомists

Leucippus, 57. Leucippus and Democritus, 58. Democritus: The fragments, 59. The "Golden Sayings" of Democritus, 60 . The atomists on the soul according to Aristotle, 65. 


\section{VIII.-The Sophists}

Two sayings of Protagoras, 67. A saying of Gorgias, 67. An account of the calling and profession of the Sophist from the writings of Plato, 68. Aristotle on the Sophists, 69. The Sophists and the Athenian youth, 69. The Protagorean doctrine of relativity as Plato interprets it in the Theatetus, 78. Gorgias as a rhetorician, 85 .

IX.-Socrates .

Aristotle on Socrates's achievement, 86. Xenophon's tribute to Socrates, 86. The sort of questions Socrates was concerned with, 90 . Socrates on the Good and the Beautiful, 91. Socrates's method, 95. A bit of his biography, as reported by Plato, 96. An illustration of his method of showing up ignorance, 101.

X.-Socrates's Defence of Himself as Reported by Plato in the A POLOGY . . . . . . . . 104

XI.-The Lesser Socrates . . . . . . . . 142

The Cyrenaics. Aristippus, 142. The Cynics. Antisthenes and Diogenes, 145.

XII.-Plato

Plato's relation to his predecessors according to Aristotle, 148. From the Phoedrus: Dialectic vs. rhetoric, 149. From the Symposium: On love, 152. From the Philebus: Pleasure and the other goods, 157. From the Timaus: The creation of the world, 160 . Why it is necessary to assume the existence of the Ideas, 167. From the Parmenides: Puzzles presented by the theory of ideas, 168 .

\section{XIII.-Plato-Continued}

From the Republic: The nature of virtue, 180. The four cardinal virtues, 182 . The higher education leading up to the Idea of the Good, 186. The Idea of the Good as the source of truth and of reality, 192. Reality and appearance; knowledge and opinion, 199. The allegory of the den; shadows and realities, 203. Dialectic the coping stone of the sciences, 213. 
Origin and nature of philosophy, 217. Aristotle's criticism of the theory of ideas, 220. Aristotle's own view regarding the universal, 223. The four causes, 225. Aristotle's conception of God: Necessity of assuming a first cause or prime mover, 227. Divine reason as the prime mover, 230. Divine reason and its object, 233.

\section{XV.-Aristotle on Psychology}

The nature of the soul, 236 . The animate and the inanimate, 240. Nourishment the fundamental function, touch the fundamental sense, 242. Sense-perception, 243. Cognition, 244. Creative reason, 246. Reason and judgment, 247. Reason and its object, 248. The springs of action, 249.

\section{XVI.-Aristotle on Ethics}

The summum bonum, 251. To find it we ask what is man's function, 253. How virtue is acquired, 257. Virtue and vice alike voluntary, 259. On friendship, 261. Highest happiness found in the vision of truth, 264. How the end is to be realized, 266 .

\section{XVII.-The Storcs .}

The parts of philosophy and the criterion of truth, 269. Ethics: Following nature, 272. The Hymn of Cleanthes, 277. Plutarch's refutation of the Stoic theodicy, 278.

\section{XVIII.-EPICURUS}

Theory of knowledge, 290. Physical speculations, 293. The practical philosophy of Epicurus, 296. Some maxims of Epicurus, 302.

\section{XIX.-Lucretius}

The wages of philosophy, 305 . The course of the atoms, 307. The unconcerned gods, 309. The nature of mind and soul, 309. Dispelling the dread of death, 313. No designer of nature, 316 . 
XX- PAax

XX.-Epictetus • • • • • • • • • 317

Things which are in our power, 317 . The essence of good, 320. As Socrates would have done, 322. In harmony with God and His universe, 324.

XXI.-Marcus Aurelius . • • . • • • . 326

Follow nature, 326. The harmony of the universe, 331.

Man's insignificance and his grandeur, 336.

XXII.-Plotinus • • • • • . . . . . 340

The soul, 340. The intellect, 353. The One, 363. The process of emanation, 371 .

XXIII.-Plotinus-Continued . • • • • • • 375

Matter, 357. Sin and salvation, 384. 


\section{I \\ THE MILESIAN SCHOOL}

\section{THALES}

[Flourished 585 B.c.]

GENERAL STANDPOINT OF THE EARLY PHILOSOPHERS AND TKE OPINIONS OF THALES

MosT ${ }^{1}$ of the early philosophers were content to seek a material first principle as the cause of all things. For that of which all things consist, from which they arise, into which they pass away, the substance remaining the same through all its changing states-that, I say, is what they mean by the element, or the first principle, of the things that are. And this is why they hold that, strictly speaking, nothing comes into being or perishes, since the primal nature remains ever the same. For instance, when Socrates becomes handsome or cultured we do not just say he comes into being; nor, when he loses these characteristics, do we say that Socrates is no more. Socrates, the subject, remains the same throughout these changes. And it is the same with all things. There must be some natural body ( $\phi \dot{v} \sigma \iota s$ ), one or many, from which all things arise, but which itself remains the same.

But of what sort this first principle is, and how many such there are, this is a point upon which they are not agreed. Thales, the originator of this kind of philosophy,

${ }^{1}$ Aristotle, Met. I. 3, 983 b 6 (R. P. 9 A). 
declares it to be water. (And this is why he said that the earth floats on water.) Possibly he was led to this opinion by observing that the nourishment of all things is moist, and that heat itself is generated and kept alive by moisture. And that from which all things are generated is just what we mean by their first principle. This may be where he got his idea, and also from observing that the germs of all things are moist, and that moist things have water as the first principle of their nature.

Some indeed hold that those who lived ages ago, long before the present generation, and who were the first to reason about the gods, held a similar view about nature, since they sang of Oceanus and Tethys as the parents of creation, and since the oath by which their gods swore was water, or, as the poets themselves called it, Styx. Now that which is most held in esteem is the object by which men swear; and that which is most ancient is that which is most esteemed. Whether there be any such ancient and primitive opinion about nature is doubtless an obscure question. However, Thales is said to have expressed the opinion above set forth concerning the first cause.

And ${ }^{2}$ some hold that the soul $\nmid$ is diffused through the universe. Perhaps this is what led Thales to say that all things are full of gods.

${ }^{2}$ Aristotle, Psychology, I. 5, 411 a 7 (R. P. 10 A).

† One must beware of reading later meanings into the word 'soul.' To 'have soul' ( $\psi v \chi \eta\rangle \nu$ ¿ $\chi \epsilon \iota \nu)$ means little more than 'to be alive.' 'Vital principle' would perhaps express the meaning better, were it not for the fact that that expression implies a greater degree of abstraction than we can properly attribute to these early thinkers. 
Judging ${ }^{3}$ from what is reported of him, Thales appears to have viewed the soul as something having the capacity to set up movement, if it is true that he said that the loadstone has a soul because it moves iron.

\section{ANAXIMANDER}

[Flourished about 570 B.c.] THE "BOUNDLESS" AS FIRST PRINCIPLE

Among ${ }^{4}$ those who say that the first principle is one and mobile and boundless is to be reckoned Anaximander of Miletus, the son of Praxiades, the successor and follower of Thales. He said that "the boundless"

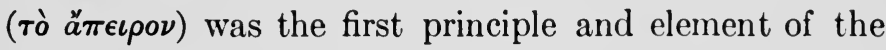
things that are, being the first to make use of this term in describing the first principle. He says it is neither water nor any of the other elements now recognized, but some other and different natural body which is boundless; and from it arise all the heavens and all the worlds which they contain.

That from which things take their origin, into that again they pass away, as destiny orders; for they are punished and give satisfaction to one another for their injustice in the ordering of time, as he puts it in rather poetical language.

It is evident that, observing the way in which the four elements are transformed into one another, he thought fit to take for the substratum, not some one

'Aristotle, 405 a 17 (R. P. 10 B).

- Theophr. Fr. 2 ap. Simplic. Phys., 24 (Dox. 476; R. P. 12). [I use throughout the customary abbreviations,-—"Dox." for Diels' Doxographi Græci, and "R. P." for Ritter and Preller, Historia Philosophice Grecce.] 
of them, but rather something else over and above them all. And he did not attribute creation ( $\gamma^{\prime} \dot{v e \sigma \iota s) ~ t o ~}$ any change in this element, but rather to the separating of the opposites occasioned by the eternal movement. This is why Aristotle compares his view with that of Anaxagoras.

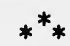

And ${ }^{5}$ he says that this principle, which encompasses all worlds, is eternal and ageless.-And besides this, there is eternal movement in which there results the creation of the heavens.

And 6 there is another point of view from which one does not make the cause any change of matter, nor ascribe creation to any transformation of the substratum, but rather to separation. Anaximander says that the opposites inhering in the substratum, which is a boundless body, are separated out, - - he being the first to name the substratum as first principle. And the "opposites" are, hot and cold, moist and dry, etc.

\section{$*^{*} *$}

Everything 7 either is a first principle or arises from a first principle; but of the boundless there is no first principle, for to find a first principle for it would be to give it bounds. Further, it (the boundless) is unbegotten and indestructible, being a first principle. That which is created perishes, and there is a limit to all destruction. Therefore there is no first principle of the boundless, but it is rather the first principle of other things. And it encompasses all things and rules all things, in the opinion of those who do not assume, in

- Hipp. Ref. I. 6 (Dox. 559; R. P. 13).

- Simpl. Phys. 150, 29 D (R. P. 14 A).

'Aristotle, Phys. III. 4, 203 b 6 (R. P. 13). 
addition to the boundless, some other cause such as "reason," or "love." And this is the divine, for it is deathless and indestructible, as Anaximander holds in agreement with most of the physical philosophers.

But 8 it is not possible that there should be an infinite body which is one and simple; either, as some hold, something over and above the elements and from which they arise, or as one of the elements themselves. For there are some who hold that this (i. e., the something other than the elements) is the boundless, and not air or water, in order that other things may not be destroyed by the boundless. For these (elements themselves) are opposed to one another; air is cold, water moist, fire hot. If one of them were boundless, the rest would have perished ere this. So they say that the boundless is something other than the elements and that from it they arise.

\section{SCIENTIFIC SPECULATIONS}

The ${ }^{9}$ earth hangs free, supported by nothing. It keeps its place because it is in the centre (lit. is equally distant from all things). It is convex and round, like a stone pillar. $\dagger$ There are two surfaces opposite one another, on one of which we are.

The stars are circles of fire, separated from the fire which surrounds the world and covered all around with air. But there are breathing holes, certain tube-like openings, through which the stars appear. When these holes close there is an eclipse; and the moon appears now

8 Aristotle, Phys. III. 5, 204 b 22 (R. P. 12 в).

- Hipp. Ref. I. 6 (Dox. 559-60; R. P. 14 c).

† So Diels, Dox. 218, and after him Burnet, p. 72, note. The 'convex' is then taken as referring to the surface of the earth. 
to wax and now to wane through the opening and closing of these holes. . . . The sun is highest of all the heavenly bodies and lowest are the circles of the fixed stars. . . . Rain comes from the vapor drawn up from the earth by the sun.

From ${ }^{10}$ the eternal principle was separated at the creation of the world something generative of hot and cold; and from this a sphere of flame grew around the air which surrounds the earth, as the bark grows around the tree. And when the sphere was broken up, and cut into distinct rings, the sun and the moon and the stars came into being.

Living ${ }^{11}$ things sprang from (the moist element $\dagger$ ) evaporated by the sun. Man sprang from a different animal, in fact from a fish, which at first he resembled.

(Anaximander) ${ }^{12}$ says that at first man sprang from a different kind of animal, his reason being that whereas all the other animals are speedily able to find nourishment for themselves, man alone requires a long period of suckling; and if he had been at the beginning such as he is now, he would not have survived.

\section{$*^{*} *$}

The ${ }^{13}$ first living things were generated in moisture, and were covered with a hard skin. When they were old enough they came up on the dry banks, and after a while the skin cracked off, and they lived on.

\footnotetext{
${ }^{10}$ Ps. Plut. Strom. 2 (R. P. 14 B; Dox. 579).

"Hipp. Ref. I. 6 (R. P. 16; Dox. 560).

12 Ps. Plut. Strom. 2 (R. P. 16; Dox. 579) .

${ }^{13}$ Aet. Plac. V, 19 (R. P. 16; Dox. 430).

$\dagger$ Cf. Diels, Dox., 560, noto.
} 


\section{ANAXIMENES \\ [Flourished about 550 B.c.] \\ THE OPINIONS OF ANAXIMENES}

Anaximenes ${ }^{14}$ said air was the first principle.

Anaximenes of Miletus, ${ }^{15}$ son of Eurystratos, an associate of Anaximander, agreed with him in holding that the substance of nature was one and boundless; but he did not agree with him in holding that it was indeterminate, for he said it was air. But it differs in rarity and density with different things. When it is very attenuated fire arises; when it is condensed wind, then cloud, then, when more condensed, water, earth, stones; and other things come from these. He too holds the movement eternal by which the changes arise.

Just ${ }^{16}$ as our soul which is air holds us together, so it is breath and air that encompasses the whole world.

All 17 things are generated by a sort of rarefaction and condensation of air.

The ${ }^{18}$ earth is flat like a table top.

The 19 earth is flat and floats on the air.

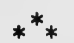

\section{$*^{*} *$}

The ${ }^{20}$ stars are fixed like nails in the crystalline vault.

14 Arist. Met. I 3, 984 a 5.

15 Theophr. Fr. 2, ap. Simplic. Phys., 24 (R. P. 19 в; Dox. 476).

10 Aet. Plac. I. 3, 4 (Dox. 278; R. P. 18).

17 Ps. Plut. Strom. Fr. 3 (R. P. 19 ^; Dox. 579).

18 Aet. Plac. III. 10, 3 (Dox. 377).

10 Hipp. Ref. I, 7 (R. P. 21; Dox. 560).

20 Aet. 14, 3 (Dox. 344). 


\section{THE ELEATIC SCHOOL,}

\section{XENOPHANES}

[Flourished about 530 B.c.]

THE FRAGMENTS

1.† There is one god, supreme among gods and men; resembling mortals neither in form nor in mind.

2. The whole of him sees, the whole of him thinks, the whole of him hears.

3. Without toil he rules all things by the power of his mind.

4. And he stays always in the same place, nor moves at all, for it is not seemly that he wander about now here, now there.

5. But mortals fancy gods are born, and wear clothes, and have voice and form like themselves.

6. Yet if oxen and lions had hands, and could paint with their hands, and fashion images, as men do, they would make the pictures and images of their gods in their own likeness; horses would make them like horses, oxen like oxen.

(D. 16) Ethiopians $\dagger \dagger$ make their gods black and snub-nosed; Thracians give theirs blue eyes and red hair.

34. Xenophanes ${ }^{1}$ said it was just as impious to say

1 Aristotle, Rhet. II. 23. 1399 B 6.

† The numbers given the fragments are those of Karsten.

†† R. P. 83. Fr. 16 in Diels' arrangement in his Die Fragmente der Vorsokratiker, a work hereafter referred to as "Diels." 
that the gods are born as to say that they die. For it follows from either view that at some time or other they do not exist.

7. Homer and Hesiod have ascribed to the gods all deeds that are a shame and a disgrace among men: thieving, adultery, fraud.

16. The gods did not reveal all things to men at the start; but, as time goes on, by searching, they discover more and more.

14. There never was, nor ever will be, any man who knows with certainty the things about the gods and about all things which I tell of. For even if he does happen to get most things right, still he himself does not know it. But mere opinions all may have.

15. Let these opinions of mine pass for semblances of truths.

37. (Upon ${ }^{2}$ Empedocles remarking to him (Xenophanes) that it was impossible to find a wise man he replied: Very likely; it takes a wise man to know a wise man when he finds one.)

8. From earth to earth,- - the beginning and end of all things.

9. We all sprang from earth and water.

10. All things that come into being and grow are earth and water.

12. The upper limit of the earth we see at our feet, where it strikes against the air; but below it reaches down without limit.

13. The (rainbow) which men call Iris is also by nature a cloud, of aspect purple and red and green.

19. Let one but win a race through fleetness of foot, or be victorious in the pentathlon, there where lies the

${ }^{2}$ Diog. Laert. IX. 20. 
sacred field of Zeus, in Olympia, hard by the river of Pisas; or let him be victorious in wrestling, or in a bloody boxing match, or in the terrible contest called the pancration,-in the eyes of the citizens he will be resplendent with glory; he will gain a conspicuous seat of honor in the public assemblies, there will be feasting for him at the public expense, and a gift from his city for a token. Yes, if he should win a chariot race, all these things would fall to his lot, though not so deserving as I am. For our wisdom is better than the strength of men or of horses. This is in truth a most heedless custom; nor is it right thus to prefer strength to precious wisdom.

What if there be among the people a good boxer, or one who excels in the pentathlon, or in wrestling, or in fleetness of foot,- which is more highly honored than strength in the contests at the games! The city is not on that account one whit better governed. Small profit does the city get out of it, when one is victorious in contests by the banks of the Pisas. That does not enrich the innermost parts of the state.

20. Having learned from the Lydians useless luxuries, what time they were free from hateful servitude, they used to come swaggering into the place of assembly by the thousand, wearing loose mantles all purple-dyed, glorying in their flowing comely hair, and reeking with the odor of curiously compounded perfumes.

AN ILLUBTRATION OF XENOPHANES' BCIENTIFIC REASONING

Xenophanes ${ }^{3}$ thought that a mixture of land and sea came into being, and that in course of time this was resolved into its parts under the influence of the moist

'Hipp., Ref. I. 14 (R. P. 86 A; Dox. 565). 
element. And he adduces such proofs as these: Fossils are found in the midst of the land and on mountains; and in the quarries of Syracuse the imprints of a fish and of seals have been found; and at Paros the imprint of a sardine deep in stone; and at Malta traces of all sorts of things of the sea. And he says that these were made when, long ago, all things were mud, and the imprint was dried in the mud. And when the earth, having sunk in the sea, becomes mud once more, all men will disappear. Then a new creation will begin. And this change happens to all worlds.

\section{PARMENIDES}

[Flourished about 495 B.c.]

TII FRAGMENTS OF PARMENIDh' POEM "ON NATURE" $\dagger$

\section{Introduction}

Soon as the coursers that bear me and drew me as far as extendeth

Impulse, guided me and threw me aloft in the glorious pathway,

Up to the Goddess that guideth through all things man that is conscious,

There was I carried along, for there did the coursers sagacious,

Drawing the chariot, bear me, and virgins preceded to guide them-

Daughters of Helios leaving behind them the mansions of darkness-

† The translation of Parmenides' poem On Nature that is here given was made by Thomas Davidson, and published in Vol. IV of the Journal of Speculative Philosophy. 
Into the light, with their strong hands forcing asunder the night-shrouds,

While in its socket the axle emitted the sound of a syrinx, Glowing, for still it was urged by a couple of wheels wellrounded,

One upon this side, one upon that, when it hastened its motion.

There were the gates of the paths of the Night and the paths of the Day-time.

Under the gates is a threshold of stone and above is a lintel.

These too are closed in the ether with great doors guarded by Justice-

Justice the mighty avenger, that keepeth the keys of requital.

Her did the virgins address, and with soft words deftly persuaded,

Swiftly for them to withdraw from the gates the bolt and its fastener.

Opening wide, they uncovered the yawning expanse of the portal,

Backward rolling successive the hinges of brass in their sockets,-

Hinges constructed with nails and with clasps; then onward the virgins

Straightway guided their steeds and their chariot over the highway.

Then did the goddess receive me with gladness, and taking my right hand

Into her own, thus uttered a word and kindly bespake me:

Youth that art mated with charioteers and companions immortal, 
Coming to us on the coursers that bear thee, to visit our mansion,

Hail! for it is not an evil Award that hath guided thee hither,

Into this path-for, I ween, it is far from the pathway of mortals-

Nay, it is Justice and Right. Thou needs must have knowledge of all things,

First of the Truth's unwavering heart that is fraught with conviction,

Then of the notions of mortals, where no true conviction abideth;

But thou shalt surely be taught this too, that every opinion

Needs must pass through the ALL, and vanquish the test with approval.

\section{On Truth}

Listen, and I will instruct thee-and thou, when thou hearest, shalt ponder-

What are the sole two paths of research that are open to thinking.

One path is: That Being doth be, and Non-Being is not: This is the way of Conviction, for Truth follows hard in her footsteps.

Th' other path is: That Being is not, and Non-Being must be;

This one, I tell thee in truth, is an all-incredible pathway.

For thou never canst know what is not (for none can conceive it),

Nor canst thou give it expression, for one thing are Thinking and Being. 
.... And to me 'tis indifferent

Whence I begin, for thither again thou shalt find me returning.

Speaking and thinking must needs be existent, for IS is of being.

Nothing must needs not be; these things I enjoin thee to ponder.

Foremost of all withdraw thy mind from this path of inquiry,

Then likewise from that other, wherein men, empty of knowledge,

Wander forever uncertain, while Doubt and Perplexity guide them-

Guide in their bosoms the wandering mind; and onward they hurry,

Deaf and dumb and blind and stupid, unreasoning cattleHerds that are wont to think Being and Non-Being one and the self-same,

Yet not one and the same; and that all things move in a circle.

Never I ween shalt thou learn that Being can be of what is not;

Wherefore do thou withdraw thy mind from this path of inquiry,

Neither let habit compel thee, while treading this pathway of knowledge,

Still to employ a visionless eye or an ear full of ringing, Yea, or a clamorous tongue; but prove this vexed demonstration

Uttered by me, by reason. And now there remains for discussion 
One path only: That Being doth be-and on it there are tokens

Many and many to show that what is is birthless and deathless,

Whole and only-begotten, and moveless and everenduring:

Never it was or shall be; but the ALL simultaneously now is,

One continuous one; for of it what birth shalt thou search for?

How and whence it hath sprung? I shall not permit thee to tell me,

Neither to think: 'Of what is not,' for none can say or imagine

How Not-Is becomes Is; or else what need should have stirred it,

After or yet before its beginning, to issue from nothing? Thus either wholly Being must be or wholly must not be. Never from that which is will the force of Intelligence suffer

Aught to become beyond itself. Thence neither production

Neither destruction doth Justice permit, ne'er slackening her fetters;

But she forbids. And herein is contained the decision of these things;

Either there is or is not; but Judgment declares, as it needs must,

One of these paths to be uncomprehended and utterly nameless,

No true pathway at all, but the other to be and be real.

How can that which is now be hereafter, or how can it have been? 
For if it hath been before, or shall be hereafter, it is not:

Thus generation is quenched and decay surpasseth believing.

Nor is there aught of distinct; for the All is self-similar alway.

Nor is there anywhere more to debar it from being unbroken;

Nor is there anywhere less, for the All is sated with Being;

Wherefore the All is unbroken, and Being approacheth to Being.

Moveless, moreover, and bounded by great chains' limits it lieth,

Void of beginning, without any ceasing, since birth and destruction

Both have wandered afar, driven forth by the truth of conviction.

Same in the same and abiding, and self through itself it reposes.

Steadfast thus it endureth, for mighty Necessity holds it-

Holds it within the chains of her bounds and round doth secure it.

Wherefore that that which IS should be infinite is not permitted;

For it is lacking in naught, or else it were lacking in all things.

Steadfastly yet in thy spirit regard things absent as present;

Surely thou shalt not separate Being from clinging to Being, 
Nor shalt thou find it scattered at all through the All of the Cosmos,

Nor yet gathered together.

One and the same are thought and that whereby there is thinking;

Never apart from existence, wherein it receiveth expression,

Shalt thou discover the action of thinking; for naught is or shall be

Other besides or beyond the Existent; for Fate hath determined

That to be lonely and moveless, which all things are but a name for-

Things that men have set up for themselves, believing as real

Birth and decay, becoming and ceasing, to be and to not-be,

Movement from place to place, and change from color to color.

But since the uttermost limit of Being is ended and perfect,

Then it is like to the bulk of a sphere well-rounded on all sides,

Everywhere distant alike from the centre; for never there can be

Anything greater or anything less, on this side or that side;

Yea, there is neither a non-existent to bar it from coming Into equality, neither can Being be different from Being, More of it here, less there, for the All is inviolate ever. Therefore, I ween, it lies equally stretched in its limits on all sides. 
And with this I will finish the faithful discourse and the thinking

Touching the truth; and now thou shalt learn the notions of mortals.

Learn and list to the treach'rous array of the words I shall utter.

\section{On Opinion}

Men have set up for themselves twin shapes to be named by Opinion

(One they cannot set up, and herein do they wander in error),

And they have made them distinct in their nature, and marked them with tokens,

Opposite each unto each - the one, flame's fire of the ether, Gentle, exceedingly thin, and everywhere one and the self-same,

But not the same with the other; the other, self-similar likewise,

Standing opposed, by itself: brute night, dense nature and heavy.

All the apparent system of these will I open before thee, So that not any opinion of mortals shall ever elude thee.

All things now being marked with the names of light and of darkness,

Yea, set apart by the various powers of the one or the other,

Surely the All is at once full of light and invisible darkness, Both being equal, and naught being common to one with the other. 
For out of the formless fire are woven the narrower circlets, Those over these out of night; but a portion of flame shooteth through them.

And in the centre of all is the Goddess that governeth all things:

She unto all is the author of loathsome birth and coition, Causing the female to mix with the male, and by mutual impulse

Likewise the male with the female.

Foremost of gods, she gave birth unto Love; yea, foremost of all gods.

Then thou shalt know the ethereal nature and each of its tokens-

Each of the signs in the ether, and all the invisible workings

Wrought by the blemishless sun's pure lamp, and whence they have risen.

Then thou shalt hear of the orb-eyed moon's circumambient workings,

And of her nature, and likewise discern the heaven that surrounds them,

Whence it arose, and how by her sway Necessity bound it Firm, to encircle the bounds of the stars.

... How the earth, and the sun, and the moon, and the ether

Common to all, and the milk of the sky, and the peak of Olympus,

Yea, and the fervent might of the stars, were impelled into being. 
Circling the earth, with its wanderings, a borrowed, a night-gleaming splendor.

Wistfully watching forever, with gaze turned toward the sunlight.

Even as in each one of men is a union of limbs manyjointed,

So there is also in each one a mind; for one and the same are

That which is wise and the nature generic of members in mortals,

Yea, unto each and to all; for that which prevaileth is thinking.

Here on the right hand the youths, and there on the left hand the maidens.

Thus by the strength of opinion were these created and now are,

Yea, and will perish hereafter, as soon as they grow unto ripeness;

Men have imposed upon each one of these a name as a token.

\section{PLATO AND ARISTOTIE ON ELEATIC PHILOSOPHY}

And ${ }^{4}$ our Eleatic tribe of philosophers, beginning with Xenophanes-yes and earlier, embodied this truth in a tale, that "all things," so-called, are really one.

\section{$*^{*} *$}

Some ${ }^{5}$ have put forth the opinion that the All is a

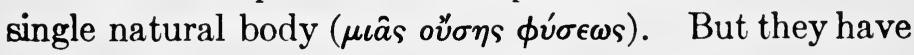

- Plato, Soph. 242 D.

- Aristotle, Met. I. 5, 986 b 11. 
not all expressed this opinion in the same way: they differ in excellence of statement, and also as to what that natural body is. The account of them lies quite outside our present inquiry into causes; for they do not, like some of the physical philosophers, first assume that that which is (тò òv) is a single body, and then produce things from this single body as from a material cause. They speak in a different fashion. The former add motion, in explaining the origin of the universe; whereas these say that it (the first principle) is immovable. Nevertheless, so much at least is germane to our present inquiry: Parmenides seems to have grasped the

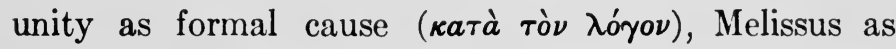

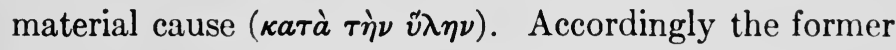
holds it to be bounded, the latter to be boundless.

Xenophanes, the first of these men to assert this unity, Parmenides being generally spoken of as his disciple, made nothing very clear, and does not seem to have reached either of the above views of nature; but, gazing up into the broad heavens, he simply declared: The One is god.

And so, as we said, these men we may pass over in our present inquiry, two of them without a further word, as being rather too crude, Xenophanes and Melissus; but Parmenides seems to speak at times with keener vision.

For, holding as he does that over and above being there is no such thing as non-being, of necessity he holds that being is One, and that there is nothing else existent. (This subject we have discussed more clearly in our work on nature.) Still, compelled to follow where the plain facts led, he supposes that whereas according to reason things are one, for sense-perception they are more 
than one; and he falls back on the assumption that there are two causes and two principles, heat and cold, to wit, fire and earth; and of these the one, the hot, he classes with being, the other (the cold) with non-being.

\section{ZENO}

[Flourished about 465 B.c.]

THE PUZzLES OF COMPOSITION AND DIVISION

If ${ }^{6}$ that which is, had no magnitude it could not even be. Everything that truly is must needs have magnitude and thickness, and one part of it must be separated from another by a certain interval. And the same may be said of the next smaller part; it too will have magnitude, and a next smaller part. As well say this once for all as keep repeating it forever. For there will be no such part that could serve as a limit. And there will never be one part save in reference to another part. Thus, if the many have being, they must be both large and small-so small as to have no size at all, and so large as to be infinite.

That ${ }^{7}$ which has neither magnitude, thickness, nor bulk could not be at all. "For," says Zeno, "were it added to anything else that is it would not make it one whit larger, for it is impossible to increase the magnitude of anything by adding that which has no magnitude. And this itself would be enough to show that what was added was nothing. . . . † If when it is taken away from

- Simpl. 140, 34. (R. P. 105 C. Fr. 2 in Diels' arrangement.)

7 Simpl. 139, 9. (R. P. 105 A. Fr. 1 Diels.)

$\dagger$ Assuming with Zeller and Burnet that there is a lacuna here. 
another thing that other will be no less, and when it is added to another thing that other will be no larger, it is clear that what was added and what was taken away was nothing at all."

If 8 the absolute unit is indivisible it would be, according to Zeno's axiom, nothing at all. For that which neither makes anything larger by its addition, nor makes anything smaller by its subtraction, is not one of the things that are, since it is clear that what is must be a magnitude, and, if a magnitude, corporeal, for the corporeal has being in all dimensions. Other things, such as the surface and the line, when added in one way make things larger, when added in another way do not; but the point and the unit do not make things larger however added.

If 9 things are a many, there must of necessity be just so many as there actually are, neither more nor less. If, however, there are just so many as there actually are, then would they be finite in number. (On the other hand) If things are a many, then the things that are are infinite in number; for, between the things that are are always other things, and between them again still other things. And thus the things that are are infinite in number.

\section{SPACE NOT A REAL THING}

If 10 space $i s$, it will be in something; for everything that is is in something; and to be in something is to be in space. Space then will be in space, and so on ad infinitum. Therefore space does not exist.

${ }^{8}$ Arist. Met. II. 4, 1001 b 7. 'Simpl. 140, 27 (R. P. 105 в).

${ }^{10}$ Simpl. 130* 562, 3 D (R. P. 106). 
THE PUZzLES OF MOTION

(1.) You $\dagger$ cannot traverse an infinite number of points in a finite time. You must traverse the half of any given distance before you traverse the whole, and the half of that again before you can traverse it. This goes on ad infinitum, so that (if space is made up of points) there are an infinite number in any given space, and it cannot be traversed in a finite time.

(2.) The second argument is the famous puzzle of Achilles and the tortoise. Achilles must first reach the place from which the tortoise started. By that time the tortoise will have got on a little way. Achilles must then traverse that, and still the tortoise will be ahead. He is always coming nearer, but he never makes up to it.

(3.) The third argument against the possibility of motion through a space made up of points is that, on this hypothesis, an arrow in any given moment of its flight must be at rest in some particular point. ${ }^{11}$

"Burnet adds: "Aristotle observes quite rightly that this argument depends upon the assumption that time is made up of 'nows,' that is, of indivisible instants. This no doubt, was the Pythagorean view."

With the third argument as given above, compare the following saying of Zeno reported by Diogenes Laertius, IX, 72: “That which moves can neither move in the place where it is, nor yet in the place where it is not."

† Zeno's arguments have been preserved by Aristotle, Phys. VI. $9,230 \mathrm{~b}$. They are, however, given in a much condensed form, being referred to as matters of common information, and are introduced in order to give Aristotle an opportunity to criticise them. In place of giving this passage I have, therefore, reproduced the arguments in the expanded form given them by Burnet, which is a free paraphrase of Aristotle's statements, with a few interpolations introduced for the benefit of the modern reader, far from the heat of the controversy, which are amply justified by Aristotle's discussions in the Physics. If any doubt should 
(4.) Suppose three parallel rows of points in juxtaposition:

FIG. 1

\begin{tabular}{lllllll|l}
$\mathrm{A}$ & $\cdot$ & $\cdot$ & $\cdot$ & $\cdot$ & $\cdot$ & $\cdot$ & $\mathrm{A}$ \\
$\mathrm{B}$ & $\cdot$ & $\cdot$ & $\cdot$ & $\cdot$ & $\cdot$ & $\cdot$ & $\mathrm{B}$ \\
$\mathrm{C}$ & $\cdot$ & $\cdot$ & $\cdot$ & $\cdot$ & $\cdot$ & $\cdot$ & $\mathrm{C}$
\end{tabular}
FIG. 2

One of these (B) is immovable, while $\mathrm{A}$ and $\mathrm{C}$ move in opposite directions with equal velocity so as to come into the position represented in Fig. 2. The movement of $\mathrm{C}$ relatively to $\mathrm{A}$ will be double its movement relatively to $\mathrm{B}$, or, in other words, any given point in $\mathrm{C}$ has passed twice as many points in $\mathrm{A}$ as it has in $\mathrm{B}$. It cannot, therefore, be the case that an instant of time corresponds to the passage from one point to another.

THE PURPOSE OF ZENO'S ARGUMENTS AS REPORTED BY PLATO

[In the Parmenides Zeno is represented as reading his work to Socrates and a few others. Before the conclusion of the reading Parmenides enters. After Zeno has finished reading a discussion ensues, part of which I quote. ${ }^{12}$ Socrates is speaking:]

"In all that you say, Zeno, have you any other purpose except to disprove the being of the many? and is not each division of your treatise intended to furnish a separate proof of this, there being in all as many proofs of the notbeing of the many as you have composed arguments? Is that your meaning, or have I misunderstood you?"

be raised on this score it could only be with regard to the fourth argument, but it seems to me that Burnet and Tannery have made good their case here. See Burnet, Early Greek Philosophy, pp. $331 \mathrm{ff}$; Tannery, Science Hellene, p. 257.

12 Parmenides, 127 D. Jowett's translation. 
"No," said Zeno; "you have correctly understood my general purpose."

"I see, Parmenides," said Socrates, "that Zeno would like to be not only one with you in friendship but your second self in his writings too; he puts what you say in another way, and would fain make believe that he is telling us something which is new. For you, in your poems, say, The All is one, and of this you adduce excellent proofs; and he on the other hand says, There is no many; and on behalf of this he offers overwhelming evidence. You affirm unity, he denies plurality. And so you deceive the world into believing that you are saying different things when really you are saying much the same. This is a strain of art beyond the reach of most of us."

"Yes, Socrates," said Zeno. "But although you are as keen as a Spartan hound in pursuing the track, you do not fully apprehend the true motive of the composition, which is not really such an artificial work as you imagine; for what you speak of was an accident; there was no pretence of a great purpose; nor any serious intention of deceiving the world. The truth is, that these arguments of mine were meant to protect the arguments of Parmenides against those who make fun of him and seek to show the many ridiculous and contradictory results which they suppose to follow from the affirmation of the one. My answer is addressed to the partisans of the many, whose attack I return with interest by retorting upon them that their hypothesis of the being of the many, if carried out, appears to be still more ridiculous than the hypothesis of the being of the one. Zeal for my master led me to write the book in the days of my youth, but some one stole the copy; and therefore I had 
no choice whether it should be published or not; the motive, however, of writing, was not the ambition of an elder man, but the pugnacity of a young one. This you do not seem to see, Socrates; though in other respects, as I was saying, your notion is a very just one." 


\section{III}

\section{HERACLITUS}

[Flourished about 505 B.c.]

THE FRAGMENTS

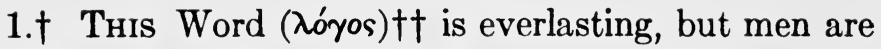
unable to comprehend it before they have heard it or even after they have heard it for the first time. Although everything happens in accordance with this Word, they behave like inexperienced men whenever they make trial of words and deeds such as I declare as I analyze each thing according to its nature and show what it is. But other men have no idea what they are doing when awake, just as they forget what they do when they are asleep.

2. One ought to follow the lead of that which is

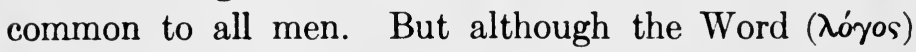
is common to all, yet most men live as if each had a private wisdom of his own.

† The numbering of the fragments is that of Diels, and I follow his text except where otherwise noted.

$\dagger+$ Burnet follows Zeller and translates $\lambda 6$ yos as "discourse," rendering the first clause: "Though this discourse is true evermore." $\lambda$ bros, it is held, did not mean "reason" in the time of Heraclitus. See Burnet, p. 133, n. 13; Zeller, I. p. 572; n. 2 . Cf. Teichmüller, Neue Studien, I. pp. $170 \mathrm{ff}$. Burnet's position is not free from objections, and, in order not to enter into the controversy, I have thought it best to follow Diels in rendering dofos "Word," and, where I have departed from that rendering, to give the Greek term also. 
17. Most men have no comprehension even of such things as they meet with, nor do they understand what they experience though they themselves think they do.

18. If you do not expect the unexpected you will never find it, for it is hard to find and inaccessible.

4. If happiness consisted in the pleasures of the body, we should call cattle happy when they find grass to eat.

5. Men seek in vain to purify themselves from bloodguiltiness by defiling themselves with blood; as if, when one has stepped into the mud, he should try to wash himself with mud. And I should deem him mad who should pay heed to any man who does such things. And, forsooth, they offer prayers to these statues here! It is as if one should try to converse with houses. They know nothing of the real nature of gods and heroes.

15. Were it not in honor of Dionysius that they made a procession and sang the Phallus-song, it were a most shameless thing to do. Is Hades then the same thing as Dionysius that they should go mad in his honor with their bacchanalian revels?

22. They who seek after gold dig up a lot of earth, and find a little.

23. Were there no injustice men would never have known the name of justice.

24. Gods and men alike honor those who fall in battle.

25. Greater deaths receive greater rewards.

(77 Bywater.) Man is kindled and put out like a light in the night time.

27. There await men after death things they do not expect nor dream of.

28. Even he who is most highly esteemed knows and cherishes nothing but opinions. And yet justice shall surely overcome forgers of lies and false witnesses. 
29. There is one thing that the best men prize above all-eternal glory above all perishable things. Most men, however, stuff themselves with food like cattle.

30. This universe, the same for all, no one, either god or man, has made; but it always was, and is, and ever shall be an ever-living fire, fixed measures kindling and fixed measures dying out.

31. The transformations of fire are, first of all, sea; and one-half of the sea is earth and half the stormy wind. . . The sea is dispersed and keeps its measure according to the same Word that prevailed before it became earth.

32. Wisdom is one and one only. It is both willing and unwilling to be called by the name of Zeus.

33. Law also means to obey the counsel of one.

34. Fools even when they hear the truth are like deaf men. Of them the proverb holds true, 'being present they are absent.'

35. Right many things must men know who are lovers of wisdom.

36. For souls it is death to become water, for water it is death to become earth. From the earth water springs, and from water soul.

37. Swine like to wash in the mire; barnyard fowls in dust and ashes.

40. Much learning does not teach wisdom, else would it have taught Hesiod and Pythagoras, Xenophanes, too, and Hecatæus.

41. Wisdom is one thing. It is to know the thought by which all things through all are guided.

42. Homer ought to be thrown out of the lists and whipped, and Archilochus too.

43. It is more necessary to extinguish wantonness than a conflagration. 
44. The people ought to fight in defence of the law as they do of their city wall.

45. You could not discover the boundaries of the soul though you tried every path, so deep does its reason (خóros) reach down.

47. Let us not make random conjectures about the weightiest matters.

48. The bow is called life, $\dagger$ but its work is death.

49. One to me is as good as ten thousand if he be but the best.

50. It is wise to hearken not to me, but to the Word, and to confess that all things are one.

8. Opposition brings men together, and out of discord comes the fairest harmony, and all things have their birth in strife.

51. Men do not understand how that which is torn in different directions comes into accord with itself,harmony in contrariety, as in the case of the bow and the lyre.

52. Time is like a child playing at draughts; the kingdom is a child's.

53. War is the father of all and the king of all, and some he has made gods and some men, some bond and some free.

54. The hidden harmony is better than that which is obvious.

57. Hesiod is most men's teacher; they are convinced that he knew nearly everything,-a man who didn't even know night and day! For they are one.

59. The straight and crooked path of the fuller's comb is one and the same.

60 . The way up and the way down is one and the same.

$\dagger$ A play on the words Blos, life, and Bı́s, bow. 
61. The sea is the purest and the impurest water; fishes drink it and it keeps them alive, men find it unfit to drink and even deadly.

62. The immortal are mortal, the mortal immortal, each living in the other's death and dying in the other's life.

67. God is day and night, winter and summer, war and peace, satiety and hunger. But he assumes various forms, just as fire when it is mingled with different kinds of incense is named according to the savor of each.

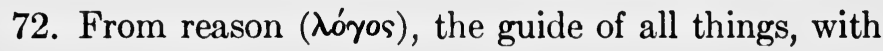
which they are most continually associated they are become estranged; and things they meet with every day appear to them unfamiliar.

73. We ought not to act and speak like men asleep.

76. Fire lives the death of air, and air the death of fire; water lives the death of earth, and earth the death of water.

(72 Bywater.) Souls delight to get wet.

78. The customs of men possess no wisdom, those of the gods do.

79. Man is called a child by god, as a boy is by man.

80. We ought to know that war is the common lot, and that justice is strife, and that all things arise through strife and necessity.

82. The most beautiful ape is ugly as compared with the human race.

83. The wisest man compared with god is like an ape in wisdom, in beauty, and in everything else.

84. In change one finds rest; and it is weariness to be always toiling at the same things and always beginning afresh. 
85. It is hard to contend against the heart; for it is ready to sell the soul to purchase its desires.

86. For the most part the knowledge of things divine escapes us because of our unbelief.

87. The stupid man is wont to be struck dumb at every word.

88. + One and the same thing are the living and the dead, the waking and the sleeping, the young and the old; the former change and are the latter, the latter change in turn and are the former.

89. Those who are awake have one world in common; those who are asleep retire every one to a private world of his own.

90. All things are exchanged for fire and fire for all things, just as wares are exchanged for gold and gold for wares.

$0 . \dagger \dagger$ All things flow; nothing abides.

91. One cannot step twice into the same river.

(81 Bywater.) Into the same rivers we step and we do not step; we are and we are not.

94 . The sun will not overstep his measures, else would the Erinnyes, the handmaids of justice, find him out.

92. The sibyl with raving lips uttering things solemn, unadorned and rude, reaches with her voice over a thousand years because of the god that inspires her.

93. The lord whose oracle is in Delphi neither reveals nor conceals but indicates.

95. It is best to hide one's folly, but it is hard when relaxed over the wine cups.

$\dagger$ Following the text of Bywater here.

†† Though this cannot be proved to be a quotation from Hersclitus, nothing is more certainly Heraclitean than the vew it expresses. It is repeatedly referred to both by Plato and by Aristotle. 
97. Dogs bark at every one whom they do not know. 101. I have sought to understand myself.

102. To god all things are beautiful and good and right; men deem some things wrong and some right.

103. In the circumference of a circle beginning and end coincide.

104. What wisdom, what understanding is theirs? They put their trust in bards and take the mob for their teacher, not knowing that many are bad and few good.

106. One day is like another.

107. Eyes and ears are bad witnesses to men who have not an understanding heart.

108. No one of all the men whose words I have heard has arrived at the knowledge that wisdom is something apart from all other things.

110. It were not good for men that all their wishes should be fulfilled.

111. It is disease that makes health pleasant; evil, good; hunger, plenty; weariness, rest.

112. Wisdom is the foremost virtue, and wisdom consists in speaking the truth, and in lending an ear to nature and acting according to her.

113-14. Wisdom is common to all. . . They who would speak with intelligence must hold fast to the [wisdom that is] common to all, as a city holds fast to its law, and even more strongly. For all human laws are fed by one divine law, which prevaileth as far as it listeth and suffices for all things and excels all things.

116. It is in the power of all men to know themselves and to practise temperance.

117. A man when he is drunk is led about by a beardless boy; he reels along paying no heed where he goes, for his soul is wet. 
118. A dry soul is the wisest and the best.

119. Man's character is his fate.

121. The Ephesians would do well to hang themselves, every man of them, and to leave the city to beardless boys. For they banished Hermodorus, the best man of them all, declaring: We will have no best man among us; if there be any such let him be so elsewhere and amongst other men.

123. Nature loves to hide.

126. It is the cold things that become warm, the warm that become cold, the moist that become dry, and the dry that become moist.

129. Pythagoras the son of Mnesarchus pursued his investigations further than all other men, . . . he made himself a wisdom of his own,-much learning, bad science. 


\section{IV}

\section{THE PYTHAGOREAN PHILOSOPHY $\dagger$}

THE NUMBER PHILOSOPHY OF THE PYTHAGOREANS

$\mathrm{AT}^{1}$ this time and even earlier $\dagger \dagger$ the so-called Pythagoreans applied themselves to mathematics and were the first to advance this branch of knowledge, and spending all their time in these pursuits they came to think that the first principles of mathematics were the first principles of all things that exist. And inasmuch as numbers are what is naturally first in this field, and since they thought they discovered in numbers a great many more similarities with things that exist and that arise in the processes of nature than one could find in fire or earth or water, they thought, for example, that such and such a property of numbers was justice, another the soul and reason, another opportunity, and in the same way of practically everything else; and inasmuch as they saw in numbers the properties and proportions of the different kinds of harmonies, and since all other things so far as their entire nature is concerned were modelled upon numbers, whereas numbers are prior to anything else in nature,--from all this they inferred that the first

$$
1 \text { Arist. Met. I. 5, } 985 \text { b } 23 .
$$

$\dagger$ Pythagoras flourished about 530 в.c.; Philolaus about 440. The number philosophy of the Pythagoreans seems to have been fully developed by the time of Philolaus.

t† Aristotle has just been speaking of Empedocles, Leucippus and Democritus. 
elements of numbers were the first elements of all things that exist, and that the whole heaven was a harmony and a number. And so all the analogies they could point to between numbers and harmonies on the one hand, and the properties and divisions and the whole arrangement of the heavens on the other hand, these they would collect and piece together, and if any gap appeared anywhere they would greedily seek after something to fill it, in order that their entire system might be coherent. For example, since they thought that the number ten was a perfect thing and included all other numbers they affirmed that the heavenly bodies must also be ten in number, but inasmuch as only nine are visible they invented a tenth, which they called the counter-earth.

These philosophers evidently regarded number as the first principle, both as being the material cause of things that exist and as describing their qualities and states as well. And the elements of number they described as the odd and the even, the former being limited and the latter unlimited; and the number one they thought was composed of both of these elements (for it is both even and odd) and from the number one all other numbers spring, and the whole heavens are simply numbers.

Others of the same school assume ten first principles which they arrange in parallel rows:

\begin{tabular}{ll|ll} 
limit & unlimited & at rest & in motion \\
odd & even & straight & crooked \\
one & many & light & darkness \\
right & left & good & evil \\
masculine & feminine & square & oblong
\end{tabular}

Alcmæon of Croton seems also to have shared this view, and indeed either he got this theory from them or 
they from him, which latter is possible for Alcmæon was a younger contemporary of Pythagoras, and he expressed views very much like those of the Pythagoreans, for he said that most human affairs are twophased; but he did not clearly define the opposites, as they did, but took them just as they came-white, black; sweet, bitter; good, evil; large, small. With regard to the rest he vaguely threw out a few random opinions; the Pythagoreans on the other hand tell us just how many and what the opposites are.

So much at least we can gather from both of these schools, that the opposites are the principles of things that are; and from one of them we can learn how many and what these opposites are. But how it is possible to bring their view back to the causes which we have ourselves laid down is a matter that has not been clearly and definitely stated by them. Apparently they put their elements under the head of material cause; for they say that it is from these elements as already existent that substance arises and that it is composed of them.$$
*^{*} *
$$

The ${ }^{2}$ so-called Pythagoreans employ first principles and elements more unusual than those of the physical philosophers, the reason being that they do not derive them from objects of sense: for the realities with which mathematics deals, if we except those of astronomy, do not partake of motion. None the less they discuss and elaborate views about nature in all its aspects; they account for the origin of the heavens, and with regard to its parts and its attributes and its activities, closely observing what happens, they apply their first principles

2 Arist. Met. I. 8, 989 b 29. 
and causes to the explanation of these things, just as if they were in entire accord with the physical philosophers in holding that existence belongs only to that which can be perceived by sense and which is comprised within what we call the heavens. But, as we have said, they introduce causes and first principles which are adapted to lead them to a higher order of realities, and indeed are more suitable for that purpose than for the explanation of nature. But from what sort of a cause movement arises, the limit and the unlimited, the odd and the even being their only presuppositions,-they say nothing of this, nor do they tell us how it is possible that, apart from motion and change, there should be generation and destruction or the revolutions of the heavenly bodies.

Moreover, if we grant them their contention that size arises from these elements, if we assume they have made this out, still the question remains how it happens that some bodies should be heavy and others light, for according to the principles which they presuppose, and from what they say about them, they are no less applicable to the things of sense than they are to the objects with which mathematics is concerned. And this is how it happens that they have said nothing about fire or earth or bodies of that sort, not having, as I suppose, anything to say that was specially applicable to things of sense. Further, how is it possible to assume that the cause of everything that exists under the heavens and all that has come into being from the beginning down to the present day is simply the properties of number and number itself, if at the same time there is no other kind of number except precisely that out of which the heavens are composed? For when in 
such and such a part of the number series they have found 'opinion,' or, possibly, 'opportunity,' and again a little higher up or a little lower down, 'injustice,' or 'judgment,' or 'mixture,' and when they have given us their proofs that every one of these things is a number, ... the question arises whether the number which we are to suppose each one of these things to be is identical with the number which is found in the heavens, or whether it is some other kind of a number over and above this.

THE PYTHAGOREAN GOLDEN WORDS $†$

The gods immortal, as by law disposed,

First venerate, and reverence the oath:

Then to the noble heroes, and the powers

Beneath the earth, do homage with just rites.

Thy parents honor and thy nearest kin, And from the rest choose friends on virtue's scale. To gentle words and kindly deeds give way, Nor hate thy friend for any slight offence.

Bear all thou canst; for Can dwells nigh to Must. These things thus know.

\section{What follow learn to rule:}

The belly first, then sleep and lust and wrath.

† A word of caution. In inserting the "Golden Words" at this point I do not mean to imply that they date from the time of the early Pythagoreans. It is now generally recognized that they have a much later origin. The earliest explicit mention of them is found in the third century B.c. But before the time of Plato the "Pythagorean Way of Life" had become proverbial, and I insert the "Golden Words" here as giving a clear picture of what in later times at least the Pythagorean Way of Life had come to represent. The translation is that of Thomas Davidson, published in his Aristotle and Ancient Educational Ideals. 
Do nothing base with others or alone:

But most of all thyself in reverence hold.

Then practise justice both in deed and word, Nor let thyself wax thoughtless about aught:

But know that death's the common lot of all.

Be not untimely wasteful of thy wealth,

Like vulgar men, nor yet illiberal.

In all things moderation answers best.

Do things that profit thee: think ere thou act.

Let never sleep thy drowsy eyelids greet,

Till thou hast pondered each act of the day:

'Wherein have I transgressed? What have I done?

What duty shunned?'-beginning from the first, Unto the last. Then grieve and fear for what

Was basely done; but in the good rejoice.

These things perform; these meditate; these love. These in the path of godlike excellence Will place thee, yea, by Him who gave our souls The number Four, perennial nature's spring! But, ere thou act, crave from the gods success.

These precepts having mastered, thou shalt know The system of the never-dying gods And dying men, and how from all the rest Each thing is sundered, and how held in one: And thou shalt know, as it is right thou shouldst, That nature everywhere is uniform, And so shalt neither hope for things that lie Beyond all hope, nor fail of any truth. 
But from such food abstain as we have named, And, while thou seek'st to purge and free thy soul, Use judgment, and reflect on everything, Setting o'er all best Thought as charioteer.

Be glad to gather goods, nor less to lose.

Of human ills that spring from spirit-powers Endure thy part nor peevishly complain. Cure what thou canst: 'tis well, and then reflect: "Fate never lays too much upon the good."

Words many, brave and base, assail men's ears. Let these not disconcert or trammel thee; But when untruth is spoken, meekly yield.

What next I say in every act observe: Let none by word or deed prevail on thee To do or say what were not best for thee. Think ere thou act, lest foolish things be done;For thoughtless deeds and words the caitiff mark;But strongly do what will not bring regret. Do naught thou dost not know; but duly learn. So shall thy life with happiness o'erflow.

Be not neglectful of thy body's health; But measure use in drink, food, exerciseI mean by "measure" what brings no distress.

Follow a cleanly, simple mode of life, And guard against such acts as envy breed. Then, if, when thou the body leav'st, thou mount To the free ether, deathless shalt thou be, A god immortal,-mortal never more! 


\section{V \\ EMPEDOCLES}

[Flourished about 455 B.c.]

THE FRAGMENTS

4. $\dagger \ldots$ Bur come, use all the hands of sense in grasping each thing in the way that it is clear. Do not put greater confidence in what thou seest than in what thou hearest, nor trust a loud noise more than the things that the tongue makes clear; and do not withhold thy confidence in any of the other hands which open a way to knowledge; but know each thing in the way it is clear.

6. Hear first the four roots of all things: brightly shining Zeus, life-bringing Hera, Aidoneus, and Nestis who bedews with her tears the well-spring of mortals.

8. And another thing I shall tell thee: of no one of all the things that perish is there any birth, nor any end in baneful death. There is only a mingling and a separation of what has been mingled. But "birth" is the name men use for this.

11. Fools! Short is the reach of their thinking who suppose that what before was not comes into being, or that anything perishes and is utterly destroyed.

12. For it is inconceivable that anything should arise from that which in no way exists, and it is impossible, and a thing unheard of, that what exists should perish, for it will always be wherever one in every case puts it.

$\dagger$ I follow the text of Diels except where otherwise noted, and give his numbering of the fragments. 
17. . . . Come hearken to my words, for learning adds strength to thy mind. As I said before, when I unfolded the chief points of my discourse, twofold is the truth I shall disclose. At one time things grew to be one alone out of many; and then again [this] fell asunder so that there were many from the one,--fire and water and earth and the endless height of the air; and, apart from these, baneful Strife, with equal weight throughout, and in their midst Love, equally distributed in length and breadth. Let thy mind's gaze rest upon her, nor sit with dazed eyes. It is she that is held to be implanted in the parts of mortals; it is she who awakens thoughts of love and fulfils the works of peace. They call her by the name of Delight and Aphrodite. No mortal man has searched her out as she swirls around in [the elements]. But do thou hearken to the guileless course of my argument. For all these [elements] are equal and of like age. Each one has a different office, each has its own character, but as time runs on they win in turn the upper hand. And besides them nothing is added, nothing taken away. For were they being continually destroyed they would no longer exist. But what could increase this All, and whence could it come? And whither could these elements pass away, since there is no place bereft of them? No, they are the same, but as they penetrate each other, sometimes one thing arises, sometimes another, and continuously and to all eternity they are the same.

35. . . . When Strife had fallen to the lowest depth of the vortex, and Love had come to be in the centre of the whirl, all things came together in Love so as to be one only,-not all at once, but coming together at their pleasure, one from this quarter, one from that. And 
as they came together Strife retired to the outermost boundary. $\dagger$ But many things unmixed remained, alternating with the things that were mixed, as many as Strife, still remaining on high, retained in its grasp; for it had not yet blamelessly retired altogether to the outermost boundaries of the circle. Partly it still remained within, and partly it had separated from the elements. But just in proportion as it was continuously rushing out a gracious and divine impulse of blameless Love kept ever coming in. And straightway things grew mortal that were wont to be immortal before, and things before unmixed were mixed, changing their ways of life. And from these as they were mingled the countless tribes of mortal creatures poured forth, fashioned in all manner of forms, a wonder to behold.

82. Hair and leaves and the thick feathers of birds and the scales that grow on tough limbs are the same thing.

100. In this wise do all breathe in and out. All have bloodless tubes of flesh stretched over the surface of the body, and at their mouths is the outermost surface of the skin pierced with pores closely packed so that the blood is kept in, while an easy way is cut for the air through the openings. Then, whenever the smooth blood rushes back, the blustering air rushes in with a furious surge, and when the blood springs back, the air is breathed out again. As when a girl playing with a klepsydra of shining brass, as long as she holds the mouth of the pipe pressed against her comely hand and dips it in the smooth mass of silvery water, the water does not flow into the vessel, but the weight of the air inside as it presses on the closely packed pores keeps

† Following Stein's arrangement instead of repeating, as Diels and Carsten do, a line given below. 
it back, until she uncovers the compressed stream [of air]. Then, however, as the air escapes, a corresponding mass of water flows in. And so in the same way when water fills the hollow of the brazen vessel, and the neck or opening is stopped by the human hand, the air outside which strives to get in holds back the water at the gates of the narrow gurgling passage, holding possession of the end, until she lets go with her hand. Then, on the contrary, the opposite of what happened before takes place, and as the air rushes in a corresponding mass of water rushes out. Just so, when the smooth blood that courses through the limbs turns backward and rushes into the interior, straightway the stream of air comes surging in, and when the blood crowds back the air breathes out again, retracing its steps.

109. For with earth we perceive earth, with water, water, with air, the air divine, and with fire, the devouring fire, and love we perceive by means of love, hate by means of dismal hate.

133. We cannot bring God near so as to reach him with our eyes or lay hold of him with our hands-the [two ways] along which the chief highway of persuasion leads into the mind of man.

134. For he has no human head attached to bodily members, nor do two branching arms dangle from his shoulders; he has neither feet nor swift knees nor any hairy parts. No, he is only mind, sacred and ineffable mind, flashing through the whole universe with swift thoughts.

SECONDARY SOURCES

$\mathrm{He}$ [Empedocles] ${ }^{1}$ makes the material elements four in number; fire, air, earth, and water. These are eternal,

${ }^{1}$ Theophrastus, Phys. Opir. 3 (Dox. 478). 
but they change in size-are large or small-through composition and separation. But, accurately speaking, he makes the first principles love and strife, for by them the others are set in motion. For the elements must continually be set in motion by each of the two in its turn, now being united by love, and anon separated by strife. Consequently there are according to him six first principles.

Empedocles speaks in the same way of all the senses, and says that we perceive through [effluences] fitting into the pores of each sense. And that is why one sense cannot pick out the objects of another, for the pores of some are too wide and of others too narrow with reference to the object of sense, so that the [effluences] either go through untouched or are unable to enter at all.

$\mathrm{He}$ tries, too, to explain the nature of the eye. He says that its interior is fire [and water]. This is surrounded by earth and watery vapor through which the fire passes like the light in lanterns. The pores of fire and water are arranged alternately. And we perceive light objects by means of the pores of fire, dark objects by means of those of water. The objects in each case fit the corresponding pores, and the colors are carried into the eye by effluences.

... Hearing, he says, is caused by sounds outside. For when [the air] is set in motion by the voice there is a sound in the ear, for hearing is like a bell sounding in the ear which he calls a "fleshy nodule." And the air when set in motion strikes on the solid parts and makes a sound.

Smell comes from breathing, and that is why those whose respiratory movement is most violent have the keenest sense of smell, and why light and subtle bodies 
exhale the strongest odors. As for taste and touch he does not explain how or by what means they arise, except to give the general explanation that sensation is due to [effluences] fitting into the pores.

Pleasure is produced by what is like, in the parts of the body and in the mixtures, pain by what is unlike.

And ${ }^{2}$ he gives a similar account of knowledge and ignorance. Thinking, he says, is caused by what is like, being ignorant, by what is unlike, speaking as if thinking were the same as sensation, or very much like it.

Moreover ${ }^{3}$ Anaxagoras and Empedocles say that [plants] are set in motion by desire, and that they perceive, and feel pleasure and pain.

... Anaxagoras, ${ }^{4}$ Democritus and Empedocles say that [plants] have mind and intelligence.

Empedocles ${ }^{5}$ was of the opinion that sex had been mixed in them.

Again ${ }^{6}$ Empedocles says that plants come into being in an inferior world that is not perfect in its completion, and when it is completed the animal comes into being.

And ${ }^{7}$ so Empedocles was wrong when he said that animals have many characteristics because it just happens so in their genesis, as, for example, that they have such a vertebrated spine because it fell to their lot to be descended from one that bent around.

- Theophrast. De Sens. (Dox. 500).

- Pseudo-Arist. De Plant. 815 a 15.

- Ib. 815 b 16.

- Ib. 817 b 35 (cf. D. 173).

- Ib. 815 a 20.

' Arist. De Part. An. 640 a 19. 
VI

\section{ANAXAGORAS}

[Flourished about 460 B.c.]

THE FRAGMENTS

1. $\dagger$ ALL things were together, in number and in smallness without limit, for the small, too, was without limit. And as long as all things were together no one of them could be clearly distinguished, because of their smallness. Yes, and air and ether, both being infinite, dominated all things, for they are the biggest things in the universe both in quantity and in size.

4. And this being so one must suppose that many things and of all sorts coexist in all [the worlds] that are brought together-seeds of all things, having all sorts of forms and colors and savors. And (in all these worlds) men have been put together, and all animals that have life; and these men possess inhabited cities and tilled fields, as we do; and they have a sun and moon and other heavenly bodies, as we have; and their earth brings forth many plants and of all sorts, the most serviceable of which they garner and use for their sustenance. This then is the view that I have put forward with regard to the differentiation [of the primal mixture],- that it takes place not with us alone but also elsewhere.

† I follow the text as given by Diels, with a few exceptions which are noted, and have given his numbering of the fragments. 
Before these things were differentiated, when all things were still together, there was not even any color clearly distinguishable, for the mixture of all things prevented it, - of the moist and the dry, the warm and the cold, the bright and the dark. (And there was much earth too in the mixture $\dagger$ ) and an endless multitude of seeds, no one like another.

5. We must know that when these things are separated one from another the whole is neither more nor less [than it was before], for it is impossible that there should be more than the whole, but the whole is always equal to itself.

17. We Greeks are wrong in using the expressions "to come into being" and "to be destroyed," for no thing comes into being or is destroyed. Rather, a thing is mixed with or separated from already existing things. And so it would be more accurate to say, instead of origin, commingling; instead of destruction, dissolution.

6. And since the parts of the great and of the small are equal in number, this is another reason for holding that all things are in everything. Nor is it possible for one of the parts to exist in isolation from the rest, but everything includes a portion of everything. Since it is impossible that there should be any least part no portion can be isolated, or come to be by itself, but as at the beginning, so now, all things are together. And in everything that has been differentiated, in what is largest as in what is smallest, many things are contained, and an equal number.

8. Nor are the things that exist in one and the same world isolated, or chopped off from one another as with

† This clause does not seem to belong in this context. The text is possibly corrupt. See Burnet, p. 285, note. 
a hatchet-the warm from the cold or the cold from the warm.

10. For how could hair come from what is not hair, flesh from what is not flesh?

9. . . . while these things are thus swirling around and becoming differentiated by force and velocity. And the velocity gives the force. But their velocity is not to be compared to the velocity of anything in our present world. It is in every way many times as swift.

15. The dense and the moist, the cold and the dark, crowded together where the earth now is; the rare, the warm, the dry, and the bright, $\uparrow$ travelled out into the far-off ether.

16. And from these as they were differentiated the earth was fashioned. For from the clouds water is separated off, from the water, earth; and from the earth stones are solidified by the influence of the cold, and they travel out still farther from the water.

11. In everything there is a portion of everything except mind. There are some things in which there is mind also.

12. All other things contain a portion of everything, but mind is infinite and self-ruled and is mixed with nothing. For if it did not exist by itself, but were mixed with anything else, it would contain a portion of all things. . . For in everything there is a portion of everything, as I have said above. And in that case the things mixed with it would prevent it from having power over anything else such as it now has, being alone and by itself. For it is the thinnest of all things and the purest, and it possesses all knowledge and the greatest

$\dagger$ Following Schorn rather than Diels here, and adding kal ro $\lambda a \mu \pi \rho \delta \nu$, after Hippolytus. 
power. And whatsoever things are alive, the largest as well as the smallest, over all is mind the ruler. And over the whole revolving universe mind held sway, so that it caused it to revolve in the beginning. The revolution first began in a small area; now it extends over a larger space, and it will extend still farther. And mind knows all things, whether mixed together, or differentiated and separate. Mind also regulated all things, - what they were to be, what they were [but are not now], and what they are; and mind regulated the revolution in which revolve the stars, the sun and the moon, and the air and the ether that are differentiated [from the primal mixture]. And it is this revolution that caused the differentiation. The dense is differentiated from the rare, the warm from the cold, the light from the dark, the dry from the moist; and there are many portions of many things. Nothing, however, is altogether differentiated and distinct from anything else, excepting only mind. And all mind, whether greater or smaller, is alike. Nothing else, however, is like anything else. But whatever portions are predominant in each individual thing, these it has always been taken to be, because they were the most conspicuous things.

13. And when mind began to set things in motion there was a differentiation of all that was in motion, and whatever mind set in motion was all separated; and when things were set in motion and separated the revolution caused them to be much more separated.

14. And mind, which is eternal, is most assuredly now also where all other things are,-in the surrounding mass, in the things that have been differentiated, and in the things that are being differentiated.

15. For there is no least of what is small: there is 
always a still smaller. For it is impossible that that which is should cease to be by being divided. On the other hand there is always a still larger than the large. And [the large] is equal to the small in number [of portions]. In itself, however, each thing is both large and small.

7. And so we cannot know either by word or by deed $\dagger$ the number of the things that have been differentiated.

21. Because of the weakness of our senses we are unable to discern the truth.

\section{SECONDARY SOURCES}

Anaxagoras ${ }^{1}$ of Clazomenæ, son of Hegesiboulus, asserted that the homoiomeries were the first principles of all that exists. How anything could arise from what is not, or pass away into nothingness, seemed to him to present insuperable difficulties. The fact is we take nourishment that is simple and uniform, such as bread and water, and from it hair, veins, arteries, flesh, nerves, bones, and other parts of the body are made to grow; and since these things come into being we must admit that in the food taken all the things that are exist, and that it is from the things that are that all things derive their increase. Consequently the food contains the parts that are generative of blood, nerves, bones, and other things, - parts which were visible only to the eye of

1 Aet. I. 3, 5 (Diels 279).

$\dagger$ As we should say, by reason or by experience. From Aristotle's discussion it would appear that the ground for this assertion is the fact that all knowing is defining and setting limits, which cannot be done in the case of what is strictly limitless. But as Anaxagoras held that mind knows all things, he must, Aristotle thinks, have held that they were limited by thought. This Aristotle holds to be inconsistent. But it need not have appeared such from the standpoint of Anaxagoras. 
reason. For we must not reduce all things to objects of sense. Sense would indicate that it is bread and water that make these things, $\dagger$ but the eye of reason can detect these portions already in the bread and water. From the fact that the portions contained in the food are like the things generated by it he called them homoiomeries; and the first principles of existing things, so far as their matter is concerned, he declared to be these homoiomeries. He began his work with these words: "All things were together; and mind separated them and put them in order."

According ${ }^{2}$ to Anaxagoras perception is by opposites; for like is not affected by like. He attempts to give the details with regard to each sense separately. Seeing, for example, is occasioned by the image on the pupil of the eye; but no image is cast on what is of the same color, but only on what is of a different color. With most animals this difference of color occurs in the daytime; with some, however, it occurs at night, and that is why they are keen-sighted at that time. Still, as a rule, night rather than day is of the same color with the eyes. And it is in the daytime that the image is cast, because light is a joint cause of the image; and the predominant color casts an image more readily on its opposite.

In the same way touch and taste discriminate their objects. For what is just as hot or just as cold as we are neither warms us nor cools us by its presence; nor do we know sweet and sour by means of themselves. By the warm we know the cold, by the brackish water

${ }_{2}^{2}$ Theophr. De Sens. 27 (Dox. 507-8).

$\dagger$ That is, blood, nerves, etc. 
the fresh, by the sour the sweet-according to our deficiency in each case. For all these things exist in us from the first. And similarly we smell at the same time that we breathe; and we hear by means of the sound penetrating to the brain-for the surrounding bone on which the sound impinges is hollow.

Further, all sensation is accompanied by pain. This would seem to be the simple consequence of his presupposition; for the contact of unlike with unlike is in every case painful. This pain is conspicuous in the case of sensations long continued or very intense; for brilliant colors and loud noises cause pain, and one cannot stand the same sensations very long.

The larger animals are the more sensitive; and, in general, sensation is an affair of size. For animals that have large, clear, and bright eyes see large things and at a great distance, and the opposite is the case with smalleyed animals. The same holds of hearing. Big ears hear loud sounds and from afar, while fainter sounds pass unnoticed: small ears hear sounds that are faint and near. The same holds of smell too. . . . Roughly speaking, large noses do not perceive a thin smell, nor small noses a thick one.

SOME OF ARISTOTLE'S COMMENTS ON ANAXAGORAS

Anaxagoras ${ }^{3}$ says that man is the wisest of animals because he has hands.

Anaxagoras, ${ }^{4}$ older in years, younger in works (than Empedocles), makes the first principles of things limitless in number. Practically all things made up of like parts arise and perish, just as fire and water do, by

${ }^{3}$ Arist. Part. An. I. 10, 687 a 7 (R. P. 127 в).

Arist. Met. I. 3, 984 a 11. 
combination and separation. In no other sense do they arise or perish. Rather, they last forever.

If 5 you follow up the theory of Anaxagoras, and develop what he meant to say, you will very likely find him speaking more like our modern philosophers. For when as yet nothing was clearly differentiated, it is obvious that one could say nothing true about that [undifferentiated] substance. I mean, for example, it was neither white nor black nor gray, nor of any other color, but was necessarily colorless. Otherwise it would have had some one of those colors. So, too, by the same line of argument, it had no taste; nor any other like quality. In fact, it could not have any quality at all, or any quantity, nor could it be any definite thing. For that would mean that it would have some definite form, which is impossible, since all things were mixed together. That is [if it had any definite characteristic], differentiation would already have taken place. But he says explicitly, all things were mixed together, with the exception of mind which alone was unmixed and pure. The inference from all this is, that he took as his first principles, Unity - for Unity is simple and unmixedand the Other, which we [Platonists?] call the indefinite before it has been defined, and before it participates in the ideas. So, while what he says is neither correct nor clear, still he means something very much like that which later philosophers, and thinkers now more in vogue, affirm.

- Arist. Met. I. 8, 989 b 4. 
VII

\section{THE ATOMISTS}

\section{LEUCIPPUS}

[Flourished about 440 B.c.]

Nothing ${ }^{1}$ comes into being without a reason, but everything arises from a specific ground and driven by necessity.

Leucippus, ${ }^{2}$ the Eleate, or the Milesian (for he is described in both ways), at first agreed with the philosophical views of Parmeniles. But he did not follow the same path as Parmenides and Xenophanes in his account of the things that are, but, apparently, just the opposite. For whereas they made the All one, immovable, uncreated and limited, and did not permit inquiry into that which is not ( assuming an unlimited number of elements, the atoms, which were always in motion. And he supposed them to have an infinite variety of forms, because there was no reason why they should have one form rather than another, and because he observed that the process of birth and change was unceasing. He further believed that that which is ( $\tau \grave{o}$ ö $\nu$ ) does not more truly exist

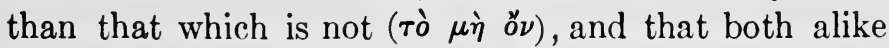
are causes of the things that come into being. For he

1 Leucippus, Fr. 2, Diels.

Theophr. Phys. Op. Fr. 8 (D. 359). 
assumed that the substance of the atoms was solid and full; and he called them "what is," and that they moved in the void, and he called that "what is not," and he said that it was no less real than that which is. And very much in the same way his associate Democritus of Abdera assumes as first principles the plenum and the void.

Leucippus ${ }^{3}$ thought he had a theory which was in accord with sense-perception, and which did not annul coming into being, or passing away, or motion, or the multiplicity of existent things. With regard to these matters he spoke the language of experience; but he agreed with the philosophers who set up the One, in holding that there is no motion apart from empty space; and he says further that empty space is non-being, and that no part of being can be non-being. For, strictly speaking, that which is, is a plenum. But, he added, being which answers to this description is not one; rather there is an infinite number of such beings, and they are invisible on account of the smallness of their bulk. They move in empty space (for there is empty space); and, coming together, they cause coming-into-being; being separated, they cause passing-away.

\section{LEUCIPPUS AND DEMOCRITUS}

In 4 the main Leucippus and Democritus explain all things in the same way and by the same argument, taking as their first principle what in the order of nature comes first. Some of the ancient philosophers had thought that that which is ( $\boldsymbol{\tau} \dot{o}$ ö $\nu$ ) must necessarily be one and immovable, for [so ran their argument] it could

3 Arist. De Gen. et Corr. 325 a 23 (D. 358).

- Arist. De Gen. et Corr. 324 b 35 (D. 358). 
not possibly move unless there were empty space apart from it, whereas empty space is non-existent; and it could not be a many unless there were empty space to keep the many asunder.

\section{DEMOCRITUS}

[Flourished about 420 B.c.]

THE FRAGMENTS

6. $†$ Man should know from this rule that he is cut off from truth.

7. This argument too shows that in truth we know nothing about anything, but every man shares the generally prevailing opinion.

8. And yet it will be obvious that it is difficult to really know of what sort each thing is.

10. Now, that we do not really know of what sort each thing is, or is not, has of ten been shown.

117. Verily we know nothing. Truth is buried deep.

9. In fact we do not know anything infallibly, but only that which changes according to the condition of our body and of the [influences] that reach and impinge upon it.

11. There are two forms of knowledge, one genuine, one obscure. To the obscure belong all of the following: sight, hearing, smell, taste, feeling. The other form is the genuine, and is quite distinct from this. (And then distinguishing the genuine from the obscure, he continues:) Whenever the obscure [way of knowing] has reached the minimum sensibile of hearing, smell, taste, and touch, and when the investigation must be carried

†The numbering of the fragments is that of Diels, and I follow his text. 
farther into that which is still finer, then arises the genuine way of knowing, which has a finer organ of thought.

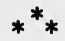

0 . [Democritus] ${ }^{5}$ says: By convention ( $\left.\boldsymbol{\nu}^{\prime} \mu \omega\right)$ sweet is sweet, by convention bitter is bitter, by convention hot is hot, by convention cold is cold, by convention color is color. But in reality there are atoms and the void. That is, the objects of sense are supposed to be real and it is customary to regard them as such, but in truth they are not. Only the atoms and the void are real.

2. Of practical wisdom these are the three fruits: to deliberate well, to speak to the point, to do what is right.

3. He who intends to enjoy life should not be busy about many things, and in what he does should not undertake what exceeds his natural capacity. On the contrary, he should have himself so in hand that even when fortune comes his way, and is apparently ready to lead him on to higher things, he should put her aside and not o'erreach his powers. For a being of moderate size is safer than one that bulks too big.

THE GOLDEN SAYINGS OF DEMOCRITUS

35. If any one hearken with understanding to these sayings of mine many a deed worthy of a good man shall he perform and many a foolish deed be spared.

37. If one choose the goods of the soul, he chooses the diviner [portion]; if the goods of the body, the merely mortal.

38. 'Tis well to restrain the wicked, and in any case not to join him in his wrong-doing.

40. 'Tis not in strength of body nor in gold that men

- Sext. Emp. Math. VII. 135. 
find happiness, but in uprightness and in fulness of understanding.

41. Not from fear but from a sense of duty ( $\delta i d$ rò $\delta \in o ́ \nu)$ refrain from your sins.

43. Repentance for one's evil deeds is the safeguard of life.

45. He who does wrong is more unhappy than he who suffers wrong.

49. 'Tis a grievous thing to be subject to an inferior.

53. Many who have not learned wisdom live wisely, and many who do the basest deeds can make most learned speeches.

54. Fools learn wisdom through misfortune.

55. One should emulate works and deeds of virtue, not arguments about it.

57. Strength of body is nobility in beasts of burden, strength of character is nobility in men.

58. The hopes of the right-minded may be realized, those of fools are impossible.

59. Neither art nor wisdom may be attained without learning.

60. It is better to correct your own faults than those of another.

61. Those who have a well-ordered character lead also a well-ordered life.

62. Good means not [merely] not to do wrong, but rather not to desire to do wrong.

64 . There are many who know many things, yet are lacking in wisdom.

77. Fame and wealth without wisdom are unsafe possessions.

78. Making money is not without its value, but nothing is baser than to make it by wrong-doing. 
68. You can tell the man who rings true from the man who rings false, not by his deeds alone, but also by his desires.

82. False men and shams talk big and do nothing.

89. My enemy is not the man who wrongs me, but the man who means to wrong me.

90. The enmity of one's kindred is far more bitter than the enmity of strangers.

98. The friendship of one wise man is better than the friendship of a host of fools.

99. No one deserves to live who has not at least one good-man-and-true for a friend.

108. Seek after the good, and with much toil shall ye find it; the evil turns up of itself without your seeking it.

111. For a man petticoat government is the limit of insolence.

118. (Democritus said he would rather discover a single demonstration than win the throne of Persia.)

119. Men have made an idol of luck as an excuse for their own thoughtlessness. Luck seldom measures swords with wisdom. Most things in life quick wit and sharp vision can set right.

154a. In the weightiest matters we must go to school to the animals, and learn spinning and weaving from the spider, building from the swallow, singing from the birds,-from the swan and the nightingale, imitating their art.

160. An evil and foolish and intemperate and irreligious life should not be called a bad life, but rather, dying long drawn out.

176. Fortune is lavish with her favors, but not to be depended on. Nature on the other hand is self- 
sufficing, and therefore with her feebler but trustworthy [resources] she wins the greater [meed] of hope.

174. The right-minded man, ever inclined to righteous and lawful deeds, is joyous day and night, and strong, and free from care. But if a man take no heed of the right, and leave undone the things he ought to do, then will the recollection of no one of all his transgressions bring him any joy, but only anxiety and self-reproaching.

175. Now as of old the gods give men all good things, excepting only those that are baneful and injurious and useless. These, now as of old, are not gifts of the gods: men stumble into them themselves because of their own blindness and folly.

178. Of all things the worst to teach the young is dalliance, for it is this that is the parent of those pleasures from which wickedness springs.

231. A sensible man takes pleasure in what he has instead of pining for what he has not.

230. A life without a holiday is like a long journey without an inn to rest at.

232. The pleasures that give most joy are the ones that most rarely come.

233. Throw moderation to the winds, and the greatest pleasures bring the greatest pains.

234. Men in their prayers beg the gods for health, not knowing that this is a thing they have in their own power. Through their incontinence undermining it, they themselves become, because of their passions, the betrayers of their own health.

191. Men achieve tranquillity through moderation in pleasure and through the symmetry of life. Want and superfluity are apt to upset them and to cause great 
perturbations in the soul. The souls that are rent by violent conflicts are neither stable nor tranquil. One should therefore set his mind upon the things that are within his power, and be content with his opportunities, nor let his memory dwell very long on the envied and admired of men, nor idly sit and dream of them. Rather, he should contemplate the lives of those who suffer hardship, and vividly bring to mind their sufferings, so that your own present situation may appear to you important and to be envied, and so that it may no longer be your portion to suffer torture in your soul by your longing for more. For he who admires those who have, and whom other men deem blest of fortune, and who spends all his time idly dreaming of them, will be forced to be always contriving some new device because of his [insatiable] desire, until he ends by doing some desperate deed forbidden by the laws. And therefore one ought not to desire other men's blessings, and one ought not to envy those who. have more, but rather, comparing his life with that of those who fare worse, and laying to heart their sufferings, deem himself blest of fortune in that he lives and fares so much better than they. Holding fast to this saying you will pass your life in greater tranquillity and will avert not a few of the plagues of life-envy and jealousy and bitterness of mind.

235. All who delight in the pleasures of the belly, exceeding all measure in eating and drinking and love, find that the pleasures are brief and last but a short whileonly so long as they are eating and drinking-but the pains that come after are many and endure. The longing for the same things keeps ever returning, and whenever the objects of one's desire are realized forthwith the pleasure vanishes, and one has no further use 
for them. The pleasure is brief, and once more the need for the same things returns.

252. We ought to regard the interests of the state as of far greater moment than all else, in order that they may be administered well; and we ought not to engage in eager rivalry in despite of equity, nor arrogate to ourselves any power contrary to the common welfare. For a state well administered is our greatest safeguard. In this all is summed up: When the state is in a healthy condition all things prosper; when it is corrupt, all things go to ruin.

THE ATOMISTS ON THE SOUL, ACCORDING TO ARISTOTLE

There ${ }^{6}$ are some who maintain that fundamentally and primarily the soul is the principle of movement. They reasoned that that which is not itself in motion cannot move anything else, and thus they regarded the soul as one of those objects which were in motion. Democritus, whose view agrees with that of Leucippus, consequently maintained soul to be a sort of fire and heat. For as the forms of the atoms are as the atoms themselves unlimited, he declares that those which are spherical in shape constitute fire and soul, these atoms being like the so-called motes which are seen in the sunbeams that enter through doorways, and it is in such a mixed heap of seeds that he finds the elements of the whole natural world. The reason why they maintain that the spherical atoms constitute the soul, is that atoms of such configuration are best able to penetrate through everything, and to set the other things in motion at the same time as they are moved themselves, the

- Arist. De An. I. 2, 403 b 30 . The passages from Aristotle's Prychology are given in Wallace's translation. 
assumption here being that the soul is that which supplies animals with motion. This same assumption led them to regard respiration as the boundary with which life was coterminous. It was, they held, the tendency of the encircling atmosphere to cause contraction in the animal body and to expel those atomic forms, which, from never being at rest themselves, supply animals with movement. This tendency, however, was counteracted by the reënforcement derived from the entrance from outside in the act of respiration of new atoms of a similar kind. These last in fact-such was their theory-as they united to repel the compressing and solidifying forces prevented those atoms already existing in animals from being expelled from them: and life, they thought, continued so long as there was strength to carry on this process.

[Democritus held] ${ }^{7}$ that the soul $\left(\psi v \chi^{\prime}\right)$ and reason

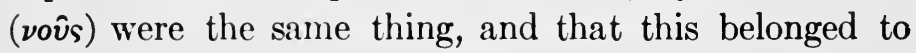
the class of primary and indivisible bodies, and had the capacity of motion because of the smallness of its parts and because of its shape. Now the most mobile shape is the spherical, and such is the shape of reason and of fire.

Arist. De An. 405 a 8. 


\section{VIII}

\section{THE SOPHISTS}

$$
\text { [440-400 в.c.] } \dagger
$$

TWO SAYINGS OF PROTAGORAS

MAN ${ }^{1}$ is a measure of all things, of things that are, that they are; and of things that are not, that they are not.

With ${ }^{2}$ regard to the gods I know not whether they exist or not, or what they are like. Many things prevent our knowing; the subject is obscure and brief is the span of our mortal life.

\section{A SAYING OF GORGIAS}

In $^{3}$ his work "On Nature, or the Non-Existent," he (Gorgias) arranges his discussion under three heads: First, nothing exists; second, if anything did exist we could never know it; third, if perchance a man should come to know it, it would remain a secret, he would be unable to describe it to his fellow-men.

${ }^{1}$ Sext. Emp. Pyrrh. h. I. 216; cf. also Plato, Cratyl. 385 E.; Theat. $151 \mathrm{E}$.

2 Eus. P. E. XIV. 3, 7; cf. Plato, Theat.

Sext. Emp. Adv. Math. VII. 67.

† Protagoras of Abdera flourished 440 B.c.; Gorgias of Leontium about the same time, or possibly a few years later; Prodicus of Ceos about 430 . 
AN ACCOUNT OF THE CALLING AND PROFESSIONS OF THE SOPHIST FROM THE WRITINGS OF PLATO, IN A DISCUSSION CARRIED ON BY THE 'ELEATIC STRANGER' AND THE.ETETUS

Eleatic Stranger.-First ${ }^{4}$ let us wait a moment and recover breath; and while we are resting we can reckon in how many forms he [the Sophist] has appeared. In the first place, he was discovered to be a paid hunter after wealth and youth. .... In the second place, he was a merchant in the goods of the soul. . . . In the third place, he has turned out to be a retailer of the same sort of wares.

Theotetus.-Yes; and in the fourth place, he himself manufactured the learned wares which he sold.

E. S.-Quite right; I will try and remember the fifth myself. He belonged to the fighting class, and was further distinguished as a debater who professed the eristic art. . . This point was doubtful; yet we at least agreed that he was a purger of souls, who cleaned away notions obstructive to knowledge. . . Again, in private conversation when any universal assertion is made about generation and essence, we know that such persons are tremendous argufiers, and are able to impart their own skill to others. . . In a word, is not the art of disputation the power of disputing about all things?

Therrt.-Certainly; there does not seem to be much that is left out.

E. S.-But oh! my dear youth, do you suppose this possible? For perhaps your young eyes may see things which to our duller sight do not appear.

Thecxt.-To what are you alluding? I don't think I understand your present question.

- From Plato's Sophist, Jowett's translation, beginning p. 231 D. 
E. S.-I asked whether anybody can understand all things.

\section{ARISTOTLE ON THE SOPHISTS}

Sophistic ${ }^{5}$ is nothing but apparent wisdom in no wise real, and the Sophist is only eager to get rich off his apparent wisdom which is not the true. Evidently these fellows seek rather to appear wise than to be wise without so appearing.

Of ${ }^{6}$ men some possess genuine health, others have the appearance only and are puffed up and deck themselves like victims for the altar. The former are fair in virtue of their own beauty; the latter look fair-when they have made their toilet.

The ${ }^{7}$ Sophist is a speculator in sham wisdom.

THF SOPHISTS AND THE ATHENIAN YOUTH

[The following graphic passage from Plato's Protagoras is given to show the acclaim with which the Sophists were received by the Athenian youth; and also to give Protagoras (through Plato) an opportunity to describe his own profession.]

Last night, ${ }^{8}$ or rather very early this morning, Hippocrates, the son of Apollodorus and the brother of Phason, gave a tremendous thump with his staff at my door; some one opened to him, and he came rushing in and bawled out: "Socrates, are you awake or asleep?"

I knew his voice and said: "Hippocrates, is that you? and do you bring any news?"

- Arist., Soph. el., I. 1, 165.

- Arist., Soph. el., I. 1, 164.

'Arist. Met. III. 2, 1004.

- From Plato's Protagoras, Jowett's translation, beginning at p. $310 \mathrm{~A}$. 
"Good news," he said; "nothing but good."

"Delightful," I said; "but what is the news? and why have you come hither at this unearthly hour?"

He drew nearer to me and said: "Protagoras is come."

"Yes," I replied; "he came two days ago: have you only just heard of his arrival?"

"Yes, by the gods," he said; "but not until yesterday evening."

At the same time he felt for the truckle-bed, and sat down at my feet, and then he said: "Yesterday quite late in the evening, on my return from Oenoe whither I had gone in pursuit of my runaway slave Satyrus, as I meant to have told you, if some other matter had not come in the way; - on my return, when we had done supper and were about to retire to rest, my brother said to me: 'Protagoras is come.' I was going to you at once, and then I thought that the night was far spent. But the moment sleep left me after my fatigue, I got up and came hither direct."

I, who knew the very courageous madness of the man, said: "What is the matter? Has Protagoras robbed you of anything?"

He replied, laughing: "Yes, indeed he has, Socrates, of the wisdom which he keeps from me."

"But, surely," I said, "if you give him money, and make friends with him, he will make you as wise as he is himself."

"Would to heaven," he replied, "that this were the case! He might take all that I have, and all that my friends have, if he pleased. But that is why I have come to you now, in order that you may speak to him on my behalf; for I am young, and also I have never seen nor heard him (when he visited Athens before I was but a 
child); and all men praise him, Socrates; he is reputed to be the most accomplished of speakers. There is no reason why we should not go to him at once, and then we shall find him at home. He lodges, as I hear, with Callias the son of Hipponicus: let us start."

I replied: "Not yet, my good friend; the hour is too early. But let us rise and take a turn in the court and wait about there until daybreak; when the day breaks, then we will go. For Protagoras is generally at home, and we shall be sure to find him; never fear."

Upon this we got up and walked about in the court, and I thought that I would make trial of the strength of his resolution. So I examined him and put questions to him. "Tell me, Hippocrates," I said, "as you are going to Protagoras, and will be paying your money to him, what is he to whom you are going? and what will he make of you? ....'

"They call him a Sophist, Socrates," he replied.

"Then we are going to pay our money to him in the character of a Sophist?"

"Certainly."

"But suppose a person were to ask this further question: 'And how about yourself? What will Protagoras make of you, if you go to see him?' "

He answered, with a blush upon his face (for the day was just beginning to dawn, so that I could see him): "Unless this differs in some way from the former instances, I suppose that he will make a Sophist of me."

"By the gods," I said, "and are you not ashamed at having to appear before the Hellenes in the character of a Sophist?" 
"Indeed, Socrates, to confess the truth, I am. . . ."

I said: "I wonder whether you know what you are doing?"

"And what am I doing?"

"You are going to commit your soul to the care of a man whom you call a Sophist. And yet I hardly think that you know what a Sophist is; and if not, then you do not even know to whom you are committing your soul and whether the thing to which you commit yourself be good or evil. . .

"If you were going to commit your body to some one, who might do good or harm to it, would you not carefully consider and ask the opinion of your friends and kindred, and deliberate many days as to whether you should give him the care of your body? But when the soul is in question, which you hold to be of far more value than the body, and upon the good or evil of which depends the well-being of your all,-about this you never consulted either with your father or with your brother or with any one of us who are your companions. But no sooner does this foreigner appear, than you instantly commit your soul to his keeping. In the evening, as you say, you hear of him, and in the morning you go to him, never deliberating or taking the opinion of any one as to whether you ought to intrust yourself to him or not;you have quite made up your mind that you will at all hazards be a pupil of Protagoras, and are prepared to expend all the property of yourself and of your friends in carrying out at any price this determination, although, as you admit, you do not know him, and have never spoken with him: and you call him a Sophist, but are manifestly ignorant of what a Sophist is; and yet you are going to commit yourself to his keeping." 
When he heard me say this, he replied: "No other inference, Socrates, can be drawn from your words."

I proceeded: "Is not a Sophist, Hippocrates, one who deals wholesale and retail in the food of the soul? To me that appears to be his nature."

"And what, Socrates, is the food of the soul?"

"Surely," I said, "knowledge is the food of the soul; and we must take care, my friend, that the Sophist does not deceive us when he praises what he sells, like the dealers wholesale or retail, who sell the food of the body; for they praise indiscriminately all their goods, without knowing what are really beneficial or hurtful: neither do their customers know, with the exception of any trainer or physician who may happen to buy of them. In like manner those who carry about the wares of knowledge, and make the round of the cities, and sell or retail them to any customer who is in want of them, praise them all alike; though I should not wonder, $\mathrm{O}$ my friend, if many of them were really ignorant of their effect upon the soul; and their customers equally ignorant, unless he who buys of them happens to be a physician of the soul. If, therefore, you have understanding of what is good and evil, you may safely buy knowledge of Protagoras or of any one; but if not, then, $\mathrm{O}$ my friend, pause, and do not hazard your dearest interests at a game of chance. For there is far greater peril in buying knowledge than in buying meat and drink: the one you purchase of the wholesale or retail dealer, and carry them away in other vessels, and before you receive them into the body as food, you may deposit them at home and call in any experienced friend who knows what is good to be eaten or drunken, and what not, and how much, and when; and then the danger of purchasing them is not so great. 
But you cannot buy the wares of knowledge and carry them away in another vessel; when you have paid for them you receive them into the soul and go your way, either greatly harmed or greatly benefited; and therefore we should deliberate and take counsel with our elders; for we are still young-too young to determine such a matter. And now let us go, as we were intending, and hear Protagoras; and when we have heard what he has to say, we may take counsel of others; for not only is Protagoras at the house of Callias, but there is Hippias of Elis, and, if I am not mistaken, Prodicus of Ceos, and several other wise men."

To this we agreed, and proceeded on our way until we reached the vestibule of the house; and there we stopped in order to conclude a discussion which had arisen between us as we were going along; and we stood talking in the vestibule until we had finished and come to an understanding. And I think that the door-keeper, who was a eunuch, and who was probably annoyed at the great inroad of the Sophists, must have heard us talking. At any rate, when we knocked at the door, and he opened and saw us, he grumbled: "They are Sophists-he is not at home"; and instantly gave the door a hearty bang with both his hands. Again we knocked, and he answered without opening: "Did you not hear me say that he is not at home, fellows?"

"But, my friend," I said, "you need not be alarmed; for we are not Sophists, and we are not come to see Callias, but we want to see Protagoras; and I must request you to announce us." At last, after a good deal of difficulty, the man was persuaded to open the door.

When we entered, we found Protagoras taking a walk in the cloister; and next to him, on one side, were walking 
Callias, the son of Hipponicus, and Paralus, the son of Pericles, who, by the mother's side, is his half-brother, and Charmides, the son of Glaucon. On the other side of him were Xanthippus, the other son of Pericles, Philippides, the son of Philomelus; also Antimœrus of Mende, who of all the disciples of Protagoras is the most famous, and intends to make sophistry his profession. A train of listeners followed him; the greater part of them appeared to be foreigners, whom Protagoras had brought with him out of the various cities visited by him in his journeys, he, like Orpheus, attracting them by his voice, and they following. I should mention also that there were some Athenians in the company. Nothing delighted me more than the precision of their movements: they never got into his way at all; but when he and those who were with him turned back, then the band of listeners parted regularly on either side; he was always in front, and they wheeled round and took their places behind him in perfect order.

After him, as Homer says, 'I lifted up my eyes and s:lw' Hippias the Elean sitting in the opposite cloister on a chair of state, and around him were seated on benches Eryximachus, the son of Acumenus, and Phædrus the Myrrhinusian, and Andron the son of Androtion, and there were strangers whom he had brought with him from his native city of Elis, and some others: they were putting to Hippias certain physical and astronomical questions, and he, ex cathedra , was determining their several questions to them, and discoursing of them.

Also, 'my eyes beheld Tantalus'; for Prodicus the Cean was at Athens: he had been lodged in a room which, in the days of Hipponicus, was a storehouse; but, as the house was full, Callias had cleared this out and made 
the room into a guest-chamber. Now Prodicus was still in bed, wrapped up in sheepskins and bedclothes, of which there seemed to be a great heap. . . . I was very anxious to hear what Prodicus was saying, for he seems to me to be an all-wise and inspired man; but I was not able to get into the inner circle, and his fine deep voice made an echo in the room which rendered his words inaudible. . . .

On entering we stopped a little, in order to look about us, and then walked up to Protagoras, and I said: "Protagoras, my friend Hippocrates and I have come to see you."

"Do you wish," he said, "to speak with me alone, or in the presence of the company?"

"Whichever you please," I said; "you shall determine when you have heard the purpose of our visit. . . ."

As I suspected that he would like to have a little display and glorification in the presence of Prodicus and Hippias, and would gladly show us to them in the light of his admirers, I said: "But why should we not summon Prodicus and Hippias and their friends to hear us?"

"Very good," he said.

"Suppose," said Callias, "that we hold a council in which you may sit and discuss." This was agreed upon, and great delight was felt at the prospect of hearing wise men talk; we ourselves took the chairs and benches, and arranged them by Hippias, where the other benches had been already placed. Meanwhile Callias and Alcibiades got Prodicus out of bed and brought in him and his companions.

When we were all seated, Protagoras said: "Now that the company are assembled, Socrates, tell me about the young man of whom you were just now speaking." 
I replied: ". . . This is my friend Hippocrates, who is desirous of making your acquaintance; he would like to know what will happen to him if he associates with you. I have no more to say."

Protagoras answered: "Young man, if you associate with me, on the very first day you will return home a better man than you came, and better on the second day than on the first, and better every day than you were on the day before."

When I heard this, I said: ". . . When you say that on the first day on which he associates with you he will return home a better man, and on every day will grow in like manner,-in what, Protagoras, will he be better? and about what?"

When Protagoras heard me say this, he replied: "You ask questions fairly, and I like to answer a question which is fairly put. If Hippocrates comes to me he will not experience the sort of drudgery with which other Sophists are in the habit of insulting their pupils; who, when they have just escaped from the arts, are taken and driven back into them by these teachers, and made to learn calculation, and astronomy and geometry, and music" (he gave a look at Hippias as he said this); "but if he comes to me, he will learn that which he comes to learn. And this is prudence in affairs private as well as public; he will learn to order his own house in the best manner, and he will be able to speak and act for the best in the affairs of the state."

"Do I understand you," I said; "and is your meaning that you teach the art of politics, and that you promise to make men good citizens?"

"That, Socrates, is exactly the profession which I make." 
"Then," I said, "you do indeed possess a noble art, if there is no mistake about this; for I will freely confess to you, Protagoras, that I have a doubt whether this art is capable of being taught, and yet I know not how to disbelieve your assertion. . . ."

The PROTAgorean DOCTRINE OF RElativity as Plato INTERPIETS IT IN THE THE.ETETUS

[The question that has been raised is: What is knowledge? Thextetus has hazarded the opinion that "Knowledge is sense-perception," whereupon Socrates proceeds as follows:]

Socrates.-Well, ${ }^{9}$ you have delivered yourself of a very important doctrine about knowledge; it is indeed the opinion of Protagoras, who has another way of expressing it. Man, he says, is the measure of all things, of the existence of things that are, and of the non-existence of things that are not:-You have read him?

Thecetetus.-Oh, yes, again and again.

Soc.-Does he not say that things are to you such as they appear to you, and to me such as they appear to me, and that you and I are men?

Theaet.-Yes, he says so.

Soc.-A wise man is not likely to talk nonsense. Let us try to understand him: the same wind is blowing, and yet one of us may be cold and the other not, or one may be slightly and the other very cold?

Theat.-Quite true.

Soc.-Now is the wind, regarded not in relation to us, but absolutely, cold or not; or are we to say, with

- From Plato's Theatetus, beginning or: p. 151 E., Jowett's translation. 
Protagoras, that the wind is cold to him who is cold, and not to him who is not?

Theot.-I suppose the last.

Soc.-Then it must appear so to each of them?

Theort.-Yes.

Soc.-And 'appears to him' means the same as 'he perceives.'

\section{Thecet.-True.}

Soc.-Then, appearing and perceiving coincide in the case of hot and cold, and in similar instances; for things appear, or may be supposed to be, to each one such as he perceives them?

\section{Theort.-Yes.}

Soc.-Then perception is always of existence, and being the same as knowledge is unerring?

\section{Thect.-Clearly.}

Soc.-In the name of the Graces, what an almighty wise man Protagoras must have been! He spoke these things in a parable to the common herd, like you and me, but told the truth, 'his Truth,' in secret to his own disciples.

Thecet.-What do you mean, Socrates?

Soc.-I am about to speak of a high argument, in which all things are said to be relative; you cannot rightly call anything by any name, such as great or small, heavy or light, for the great will be small and the heavy light - there is no single thing or quality, but out of motion and change and admixture all things are becoming relatively to one another, which 'becoming' is by us incorrectly called being, but is really becoming, for nothing ever is, but all things are becoming. Summon all philosophers-Protagoras, Heracleitus, Empedocles, and the rest of them, one after another, and 
with the exception of Parmenides they will agree with you in this. Summon the great masters of either kind of poetry-Epicharmus, the prince of Comedy, and Homer of Tragedy; when the latter sings of

'Ocean whence sprang the gods, and mother Tethys,'

does he not mean that all things are the offspring of flux and motion? Then now apply his doctrine to perception, my good friend, and first of all to vision; that which you call white color is not in your eyes, and is not a distinct thing which exists out of them. And you must not assign any place to it: for if it had position it would be, and be at rest, and there would be no process of becoming.

Theoxt.-Then what is color?

Soc.-Let us carry out the principle which has just been affirmed, that nothing is self-existent, and then we shall see that white, black, and every other color, arises out of the eye meeting the appropriate motion, and that what we call a color is in each case neither the active nor the passive element, but something which passes between them, and is peculiar to each percipient; are you quite certain that the several colors appear to a dog or to any animal whatever as they appear to you?

Thext.-Far from it.

Soc.-Or that anything appears the same to you as to another man? Are you so profoundly convinced of this? Rather would it not be true that it never appears exactly the same to you, because you are never exactly the same?

Theot.-The latter.

Soc.-And if that with which I compare myself in size, or which I apprehend by touch, were great or 
white or hot, it could not become different by mere contact with another unless it actually changed; nor again, if the comparing or apprehending subject were great or white or hot, could this, when unchanged from within, become changed by any approximation or affection of any other thing. The fact is that in our ordinary way of speaking we allow ourselves to be driven into most ridiculous and wonderful contradictions, as Protagoras and all who take his line of argument would remark. ... I am charmed with his doctrine, that what appears is to each one, but I wonder that he did not begin his book on Truth with a declaration that a pig or a dogfaced baboon, or some other yet stranger monster which has sensation, is the measure of all things; then he might have shown a magnificent contempt for our opinion of him by informing us at the outset that while we were reverencing him like a God for his wisdom he was no better than a tadpole, not to speak of his fellow-menwould not this have produced an overpowering effect? For if truth is only sensation, and no man can discern another's feelings better than he, or has any superior right to determine whether his opinion is true or false, but each, as we have several times repeated, is to himself the sole judge, and everything that he judges is true and right, why, my friend, should Protagoras be preferred to the place of wisdom and instruction, and deserve to be well paid, and we poor ignoramuses have to go to him, if each one is the measure of his own wisdom? Must he not be talking 'ad captandum' in all this? I say nothing of the ridiculous predicament in which my own midwifery and the whole art of dialectic is placed; for the attempt to supervise or refute the notions or opinions of others would be a tedious and enormous piece 
of folly, if to each man his own are right; and this must be the case if Protagoras's Truth is the real truth, and the philosopher is not merely amusing himself by giving oracles out of the shrine of his book. . . .

Well, you ask, and how will Protagoras reënforce his position? Shall I answer for him?

Theoct.-By all means.

Soc.-... Oh, my good sir, he will say, Come to the argument in a more generous spirit; and either show, if you can, that our sensations are not relative and individual, or, if you admit them to be so, prove that this does not involve the consequence that the appearance becomes, or, if you will have the word, is, to the individual only. As to your talk about pigs and baboons, you are yourself behaving like a pig, and you teach your hearers to make sport of my writings in the same ignorant manner; but this is not to your credit. For I declare that the truth is as I have written, and that each of us is a measure of existence and of nonexistence. Yet one man may be a thousand times better than another in proportion as different things are and appear to him. And I am far from saying that wisdom and the wise man have no existence; but I say that the wise man is he who makes the evils which appear and are to a man, into goods which are and appear to him. And I would beg you not to press my words in the letter, but to take the meaning of them as I will explain them. Remember what has been already saidthat to the sick man his food appears to be and is bitter, and to the man in health the opposite of bitter. Now I cannot conceive that one of these men can be or ought to be made wiser than the other; nor ean you assert that the sick man because he has one impression is 
foolish, and the healthy man because he has another is wise; but the one state requires to be changed into the other, the worse into the better. As in education, a change of state has to be effected, and the Sophist accomplishes by words the change which the physician works by the aid of drugs. Not that any one ever made another think truly, who previously thought falsely. For no one can think what is not, or think anything different from that which he feels; and this is always true. But as the inferior habit of mind has thoughts of a kindred nature, so I conceive that a good mind causes men to have good thoughts; and these which the inexperienced call true, I maintain to be only better, and not truer than others. And, O my dear Socrates, I do not call wise men tadpoles: far from it; I say that they are the physicians of the human body, and the husbandmen of plants-for the husbandmen also take away the evil and disordered sensations of plants, and infuse into them good and healthy sensations-aye, and true ones; and the wise and good rhetoricians make the good instead of the evil to seem just to states; for whatever appears to a state to be just and fair, so long as it is regarded as such, is just and fair to it; but the teacher of wisdom causes the good to take the place of the evil, both in appearance and in reality. And in like manner the Sophist who is able to train his pupils in this spirit is a wise man, and deserves to be well paid by them. And so one man is wiser than another; and no one thinks falsely, and you, whether you will or not, must endure to be a measure. On these foundations the argument stands firm, which you, Socrates, may, if you please, overthrow by an opposite argument, or if you like you may put questions to me-a method to which no in- 
telligent person will object, quite the reverse. But I must beg you to put fair questions: for there is great inconsistency in saying that you have a zeal for virtue, and then always behaving unfairly in argument. The unfairness of which I complain is that you do not distinguish between mere disputation and dialectic: the disputer may trip up his opponent as often as he likes, and make fun; but the dialectician will be in earnest, and only correct his adversary when necessary, telling him the errors into which he has fallen through his own fault, or that of the company which he has previously kept. If you do so, your adversary will lay the blame of his own confusion and perplexity on himself, and not on you. He will follow and love you, and will hate himself, and escape from himself into philosophy, in order that he may become different from what he was. But the other mode of arguing, which is practised by the many, will have just the opposite effect upon him; and as he grows older, instead of turning philosopher, he will come to hate philosophy. I would recommend you, therefore, as I said before, not to encourage yourself in this polemical and controversial temper, but to find out, in a friendly and congenial spirit, what we really mean when we say that all things are in motion, and that to every individual and state what appears, is. In this manner you will consider whether knowledge and sensation are the same or different, but you will not argue, as you were just now doing, from the customary use of names and words, which the vulgar pervert in all sorts of ways, causing infinite perplexity to one another. Such, Theodorus, is the very slight help which I am able to offer to your old friend; had he been living, he would have helped himself in a far more gloriose style. 
PLATO's ACCOUNT OF GORgIAS AS A RHETORICIAN

O Meno, ${ }^{10}$ there was a time when the Thessalians were famous among the other Hellenes only for their riches and their riding; but now, if I am not mistaken, they are equally famous for their wisdom, especially at Larissa, which is the native city of your friend Aristippus. And this is Gorgias's doing; for when he came there, the flower of the Aleuadæ, among them your admirer Aristippus, and the other chiefs of the Thessalians, fell in love with his wisdom. And he has taught you the habit of answering questions in a grand and bold style, which becomes those who know, and is the style in which he himself answers all comers; and any Hellene who likes may ask him anything.

Chorephon.-Tell ${ }^{11} \mathrm{me}$, Gorgias, is our friend Callicles right in saying that you undertake to answer any questions which you are asked?

Gorgias.-Quite right, Chærephon: I was saying as much only just now; and I may add, that many years have elapsed since any one has asked me a new one. . . .

Socrates.-Gorgias, ... what are we to call you, and what is the art which you profess?

Gor.-Rhetoric, Socrates, is my art.

Soc.-Then I am to call you a rhetorician?

Gor.-Yes, Socrates, and a good one too, if you would call me that which, in Homeric language, "I boast myself to be." . . .

Soc.-[And] rhetoric, as would appear, is the artificer of a persuasion which creates belief about the just and unjust, but gives no instruction about them?

Gor.-True.

${ }^{10}$ From the Meno of Plato, p. 70 D., Jowett's translation.

11 From the Gorgias of Plato, p. 447 E., Jowett's translation. 


\section{X}

\section{SOCRATES}

$$
\text { [469-399 B.c.] }
$$

ARISTOTLE ON SOCRATES'S ACHIEVEMENT

THeRE ${ }^{1}$ are two things that one would rightly attribute to Socrates: inductive reasoning and universal definition. And in fact these two things are the very foundations of knowledge. But Socrates did not give his universals, or his definitions, separate existence. Others, however, did, and called such reals 'ideas.'

\section{XENOPHON'S TRIBUTE TO SOCRATES $\dagger$}

It ${ }^{2}$ seems wonderful to me, that any should have been persuaded that Socrates corrupted the youth; Socrates, who, in addition to what has been said of him, was not only the most rigid of all men in the government of his passions and appetites, but also most able to withstand cold, heat, and every kind of labor; and, besides, so inured to frugality, that, though he possessed very little, he very easily made it a sufficiency. How, then, being of such a character himself, could he have rendered others impious, or lawless, or luxurious, or incontinent, or too effeminate to endure labor? On the contrary, he restrained many of them from such vices, leading them

1 Arist. Met. 12, 4, 1078 b.

2 Xenophon's Memorabilia, I. 2, 1.

$\dagger$ The passages from Xenophon's Memorabilia are given in Watson's translation 
to love virtue, and giving them hopes, that if they would take care of themselves, they would become honorable and worthy characters. Not indeed that he ever professed to be an instructor in that way, but, by showing that he was himself such a character, he made those in his society hope that, by imitating him, they would become such as he was.

Of the body he was not neglectful, nor did he commend those who were. He did not approve that a person should eat to excess, and then use immoderate exercise, but recommended that he should work off, by a proper degree of exercise, as much as the appetite received with pleasure; for such a habit, he said, was peculiarly conducive to health, and did not prevent attention to the mind. He was not, however, fine or ostentatious in his clothes or sandals, or in any of his habits of life; yet he did not make those about him lovers of money, for he checked them in this as well as other passions, and asked no remuneration from those who desired his company. By refraining from such demand, he thought that he consulted his liberty, and called those who took money for their discourses their own enslavers, since they must of necessity hold discussions with those from whom they received pay. . . .

How then could a man of such a character corrupt the young, unless, indeed, the study of virtue be corruption?

[Socrates] ${ }^{3}$ disciplined his mind and body by sucn a course of life, that he who should adopt a similar one, would, if no supernatural influence prevented, live in good spirits and uninterrupted health, nor would he ever

3 Xenophon's Memorabilia, I. 3, 5. 
be in want of the necessary expenses for it. So frugal was he that I do not know whether any one could earn so little by the labor of his hands, as not to procure sufficient to have satisfied Socrates. He took only so much food as he could eat with a keen relish; and, to this end, he came to his meals so disposed that the appetite for his meat was the sauce to it. Every kind of drink was agreeable to him, because he never drank unless he was thirsty. If he ever complied with an invitation to go to a feast, he very easily guarded, what is extremely difficult to most men, against loading his stomach to excess. Those who were unable to do so, he advised to be cautious of taking anything that would stimulate them to eat when they were not hungry, and to drink when they were not thirsty; for he said that those were the things that disordered the stomach, the head, and the mind; and he used to say, in jest, that he thought Circe transformed men into swine, by entertaining them with abundance of such luxuries, but that Ulysses, through the admonition of Mercury and through being himself temperate, and forbearing to partake of such delicacies to excess, was in consequence not changed into a swine.

$$
*^{*} *
$$

Concerning ${ }^{4}$ justice, too, he did not conceal what sentiments he entertained, but made them manifest even by his actions, for he conducted himself, in his private capacity, justly and beneficently towards all men, and, as a citizen, he obeyed the magistrates in all that the laws enjoined, both in the city and on military expeditions, so that he was distinguished above other men for his observance of order. When he was president

‘ Xenophon's Memorabilia, IV. 4, 1. 
in the public assembly, he would not permit the people to give a vote contrary to law, but opposed himself, in the defence of the laws, to such a storm of rage on the part of the populace as I think that no other man could have withstood. When the Thirty Tyrants commanded him to do anything contrary to the laws, he refused to obey them; for both when they forbade him to converse with the young, and when they ordered him, and some others of the citizens, to lead a certain person away to death, he alone did not obey, because the order was given contrary to the laws. When he was accused by Meletus, and others were accustomed, before the tribunal, to speak so as to gain the favor of the judges, and to flatter them, and to supplicate them, in violation of the laws, and many persons, by such practices, had of ten been acquitted by the judges, he refused, on his trial, to comply with any practices opposed to the laws, and though he might easily have been acquitted by his judges, if he had but in a slight degree adopted any of these customs, he chose rather to die abiding by the laws than to save his life by transgressing them.

To me, therefore, Socrates, being a man of such a character, appeared to be worthy of honor rather than of death; and any one, considering his case according to the laws, would find such to be the fact; for, by the laws, death is the punishment for a man if he be found stealing, or stripping people of their clothes, or cutting purses, or house-breaking, or kidnapping, or sacrilege, of which crimes Socrates was the most innocent of all men. Nor was he ever the cause of any war ending unfortunately for the state, or of any sedition or treachery; nor did he ever, in his private transactions, either deprive any man of what was for his good, or involve him in any 
evil; nor did he ever lie under suspicion of any of the crimes which I have mentioned.

How 5 then could he have been guilty of the charges brought against him? a man who, instead of not acknowledging the gods, as was stated in the indictment, evidently paid respect to the gods more than other men; and instead of corrupting the youth, as the accuser laid to his charge, plainly led such of his associates as had vicious inclinations to cease from indulging them, and exhorted them to cherish a love of that most honorable and excellent virtue, by which men successfully govern states and families. How then, pursuing such a course of conduct, was he not deserving of great honor from the city?

THE SORT OF QUESTIONS SOCRATES WAS CONCERNED WITH

$\mathrm{He}^{6}$ did not dispute about the nature of things as most other philosophers disputed, speculating how that which is called by the Sophists the world was produced, and by what necessary laws everything in the heavens is effected, but endeavored to show that those who chose such objects of contemplation were foolish; and used in the first place to inquire of them whether they thought that they already knew sufficient of human affairs, and therefore proceeded to such subjects of meditation, or whether, when they neglected human affairs entirely, and speculated on celestial matters, they thought that they were doing what became them. He wondered, too, that it was not apparent to them that it is impossible for man to satisfy himself on such points, since even those who pride themselves most on discussing them, do not

- Xenophon's Memorabilia, I. 2, 64.

- Ib., I. 1, 1 . 
hold the same opinions one with another, but are, compared with each other, like madmen. . . .

$\mathrm{He}^{7}$ would ask, also, concerning such philosophers, whether, as those who have learned arts practised by men expect that they will be able to carry into effect what they have learned, either for themselves, or for any one else whom they may wish, so those who inquire into celestial things inagine that, when they have discovered by what laws everything is effected, they will be able to produce, whenever they please, wind, rain, changes of the seasons, and whatever else of that sort they may desire, or whether they have no such expectation, but are content merely to know how everything of that nature is generated. Such were the observations which he made about those who busied themselves in such speculations; but for himself, he would hold discourse, from time to time, on what concerned mankind, considering what was pious, what impious; what was becoming, what unbecoming; what was just, what unjust; what was sanity, what insanity; what was fortitude, what cowardice; what a state was, and what the character of a statesman; what was the nature of government over men, and the qualities of one skilled in governing them; and touching on other subjects, with which he thought that those who were acquainted were men of worth and estimation, but that those who were ignorant of them might justly be deemed no better than slaves.

SOCRATES ON THE GOOD AND THE BEAUTIFUL

When ${ }^{8}$ Aristippus attempted to confute Socrates, as he himself had previously been confuted by him, Socrates, 'Xenophon's Memorabilia $\quad$ I. 1, $15 . \quad{ }^{8}$ Ib., III. 8, 1 
wishing to benefit those who were with him, gave his answers, not like those who are on their guard lest their words be perverted, but like those who are persuaded that they ought above all things to do what is right. What Aristippus had asked him was, 'whether he knew anything good,' in order that if he should say any such thing as food, or drink, or money, or health, or strength, or courage, he might prove that it was sometimes an evil. But Socrates, reflecting that if anything troubles us we want something to relieve us from it, replied, as it seemed best to do, "Do you ask me whether I know anything good for a fever?" "I do not." "Anything good for soreness of the eyes?" "No." "For hunger?" "No, nor for hunger either." "Well, then," concluded Socrates, "if you ask me whether I know anything good that is good for nothing, I neither know anything, nor wish to know."

Aristippus again asking him if he knew anything beautiful, he replied, "Many things." "Are they then," inquired Aristippus, "all like each other?" "Some of them," answered Socrates, "are as unlike one another as it is possible for them to be." "How then," said he, "can what is beautiful be unlike what is beautiful?" "Because, assuredly," replied Socrates, "one man, who is beautifully formed for wrestling, is unlike another who is beautifully formed for running; and a shield, which is beautifully formed for defence, is as unlike as possible to a dart, which is beautifully formed for being forcibly and swiftly hurled." "You answer me," said Aristippus, "in the same manner as when I asked you whether you knew anything good." "And do you imagine," said Socrates, "that the good is one thing, and the beautiful another? Do you not know that with reference to the 
same objects all things are both beautiful and good? Virtue, for instance, is not good with regard to some things and beautiful with regard to others; and persons, in the same way, are called beautiful and good with reference to the same objects; and human bodies, too, with reference to the same objects, appear beautiful and

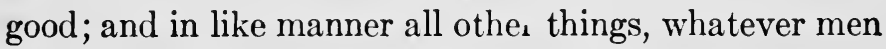
use, are considered beautiful and good with reference to the objects for which they are serviceable."

When ${ }^{9}$ some one asked ${ }^{*^{*} *}$ him what object of study he thought best for a man, he replied, "Good conduct." When he asked him again whether he thought "good fortune" an object of study, he answered, "Fortune' and 'Conduct'. I think entirely opposed; for, for a person to light on anything that he wants without seeking it, I consider to be 'good fortune,' but to achieve anything successfully by learning and sturly, I regard as 'good conduct'; and those who make this their object of study appear to me to do well."

The best men, and those most beloved by the gods, he observed, were those who, in agriculture, performed their agricultural duties well, those who, in medicine, performed their medical duties well, and those who, in political offices, performed their public duties well; but he who did nothing well, he said, was neither useful for any purpose, nor acceptable to the gods.

"But ${ }^{10}$ as to wisdom, Socrates, it is indisputably a good thing; for what business will not one who is wise conduct better than one who is untaught?" "Have you not heard, then, of Dædalus," said Socrates, "how he was

-Xenophon's Memorabilia, III. 9, $14 . \quad{ }^{10}$ Ib., IV. 2, 33. 
made prisoner by Minos and compelled to serve him as a slave; how he was cut off, at once, from his country and from liberty, and how, when he endeavored to escape with his son, he lost the child, and was unable to save himself, but was carried away among barbarians, and made a second time a slave?" "Such a story is told, indeed," said Euthydemus. "Have you not heard, too, of the sufferings of Palamedes? for everybody says that it was for his wisdom he was envied and put to death by Ulysses." "That, too, is said," replied Euthydemus. "And how many other men do you think have been carried off to the king on account of their wisdom, and made slaves there?"

"But as to happiness, Socrates," said Euthydemus, "that at least appears to be an inclisputable good." "Yes, Euthydemus," replied Socrates, "if we make it consist in things that are indisputably good." "But what," said he, "among things constituting happiness can be a doubtful good?" "Nothing," answered Socrates, "unless we join with it beauty, or strength, or wealth, or glory, or any other such thing." "But we must assuredly join them with it," said Euthydemus; "for how can a person be happy without them?" "We shall then join with it, by Jupiter," said Socrates, "things from which many grievous calamities happen to mankind; for many, on account of their beauty, are ruined by those who are maddened with passion for their youthful attractions; many, through confidence in their strength, have entered upon undertakings too great for it, and involved themselves in no small disasters; many, in consequence of their wealth, have become enervated, been plotted against, and destroyed; and many, from the glory and power that they have acquired 
in their country, have suffered the greatest calamities." "Well, then," said Euthydemus, "if I do not say what is right when I praise happiness, I confess that I do not know what we ought to pray for to the gods."

You, ${ }^{11}$ Antipho, seem to think that happiness consists in luxury and extravagance; but I think that to want nothing is to resemble the gods, and that to want as little as possible is to make the nearest approach to the gods; that the Divine nature is perfection, and that to be nearest to the Divine nature is to be nearest to perfection.

\section{SOCRATES'S METHOD}

And ${ }^{12}$ he observed that the expression $\delta \iota a \lambda \in \operatorname{c} \gamma \in \sigma \theta a \iota$, "to reason," had its origin in people's practice of meeting together to reason on matters, and distinguishing them,

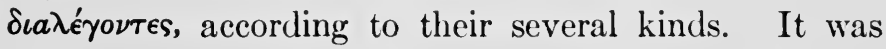
the duty of every one, therefore, he thought, to make himself ready in this art, and to study it with the greatest diligence; for that men, by the aid of it, became most accomplished, most able to guide others, and most acute in discussion.

Whenever ${ }^{13}$ any person contradicted him on any point who had nothing definite to say, and who perhaps asserted, without proof, that some person, whom he mentioned, was wiser, or better skilled in political affairs, or possessed of greater courage, or worthier in some such respect [than some other whom Socrates had mentioned], he would recall the whole argument, in some such way as the following, to the primary proposition: "Do you say that he whom you commend, is a better citizen than

"Xenophon's Memorabilia, I. 6, 10.

12 Ib., IV. 5, 12.

${ }^{13}$ Ib., IV. 7, 13. 
he whom I commend?" "I do say so." "Why should we not then consider, in the first place, what is the duty of a good citizen?" "Let us do so." "Would not he then be superior in the management of the public money who should make the state richer?" "Undoubtedly." "And he in war who should make it victorious over its enemies?" "Assuredly." "And in an embassy he who should make friends of foes?" "Doubtless." "And he in addressing the people who should check dissension and inspire them with unanimity?" "I think so." When the discussion was thus brought back to fundamental principles, the truth was made evident to those who had opposed him.

When he himself went through any subject in argument, he proceeded upon propositions of which the truth was generally acknowledged, thinking that a sure foundation was thus formed for his reasoning. Accordingly, whenever he spoke, he, of all men that I have known, most readily prevailed on his hearers to assent to his arguments; and he used to say that Homer had attributed to Ulysses the character of a sure orator, as being able to form his reasoning on points acknowledged by all mankind.

A Bit of SOCRATES'S biography REPORTEd by PLATO

[From Plato's Phødo. Socrates himself speaks:]

When ${ }^{14}$ I was young, Cebes, I had a prodigious desire to know that department of philosophy which is called the investigation of nature; to know the causes of things, and why a thing is and is created or destroyed appeared to me to be a lofty profession; and I was always agitating myself with the consideration of questions such

14 Plato, Phodo, beginning p. 96 A, Jowett's translation. 
as these:-Is the growth of animals the result of some decay which the hot and cold principle contracts, as some have said? Is the blood the element with which we think, or the air, or the fire? or perhaps nothing of the kind-but the brain may be the originating power of the perceptions of hearing and sight and smell, and memory and opinion may come from them, and science may be based on memory and opinion when they have attained fixity. And then I went on to examine the corruption of them, and then to the things of heaven and earth, and at last I concluded myself to be utterly and absolutely incapable of these inquiries, as I will satisfactorily prove to you. For I was fascinated by them to such a degree that my eyes grew blind to things which I had seemed to myself, and also to others, to know quite well; I forgot what I had before thought self-evident truths; e. g., such a fact as that the growth of man is the result of eating and drinking; for when by the digestion of food flesh is added to flesh and bone to bone, and whenever there is an aggregation of congenial elements, the lesser bulk becomes larger and the small man great. ... I am not any longer satisfied that I understand the reason why one or anything else is either generated or destroyed or is at all, but I have in my mind some confused notion of a new method, and can never admit the other.

Then I heard some one realing, as he said, from a book of Anaxagoras, that mind was the disposer and cause of all, and I was delighted at this notion, which appeared quite admirable, and I said to myself: If mind is the disposer, mind wlil dispose all for the best, and put each particular in the best place; and I argued that if any one desired to find out the cause of the generation or de- 
struction or existence of anything, he must find what state of being or doing or suffering was best for that thing, and therefore a man had only to consider the best for himself and others and then he would also know the worse, since the same science comprehended both. And I rejoiced to think that I had found in Anaxagoras a teacher of the causes of existence such as I desired, and I imagined that he would tell me first whether the earth is flat or round; and whichever was true, he would proceed to explain the cause and the necessity of this being so, and then he would teach me the nature of the best and show that this was best; and if he said that the earth was in the centre, he would further explain that this position was the best, and I should be satisfied with the explanation given, and not want any other sort of cause. And I thought that I would then go on and ask him about the sun and moon and stars, and that he would explain to me their comparative swiftness, and their returnings and various states, active and passive, and how all of them were for the best. For I could not imagine that when he spoke of mind as the disposer of them, he would give any other account of their being as they are, except that this was best; and I thought that when he had explained to me in detail the cause of each and the cause of all, he would go on to explain to me what was best for each and what was good for all. These hopes I would not have sold for a large sum of money, and I seized the books and read them as fast as I could in my eagerness to know the better and the worse.

What expectations I had formed, and how grievously was I disappointed! As I proceeded, I found my philosopher altogether forsaking mind or any other principle of order, but having recourse to air, and ether, 
and water, and other eccentricities. I might compare him to a person who began by maintaining generally that mind is the cause of the actions of Socrates, but who, when he endeavored to explain the causes of my several actions in detail, went on to show that I sit here because my body is made up of bones and muscles; and the bones, as he would say, are hard and have joints which divide them, and the muscles are elastic, and they cover the bones, which have also a covering or environment of flesh and skin which contains them; and as the bones are lifted at their joints by the contraction or relaxation of the muscles, I am able to bend my limbs, and this is why I am sitting here in a curved posturethat is what he would say; and he would have a similar explanation of my talking to you, which he would attribute to sound, and air, and hearing, and he would assign ten thousand other causes of the same sort, forgetting to mention the true cause, which is, that the Athenians have thought fit to condemn me, and accordingly I have thought it better and more right to remain here and undergo my sentence; for I am inclined to think that these muscles and bones of mine would have gone off long ago to Megara or Bootia-by the dog they would, if they had been moved only by their own idea of what was best, and if $I$ had not chosen the better and nobler part, instead of playing truant and running away, of enduring any punishment which the state inflicts. There is surely a strange confusion of causes and conditions in all this. It may be said, indeed, that without bones ard muscles and the other parts of the body I cannot execute my purposes. But to say that I do as I do because of them, and that this is the way in which mind acts, and not from the choice of the best, is a very 
careless and idle mode of speaking. I wonder that they cannot distinguish the cause from the condition, which the many, feeling about in the dark, are always mistaking and misnaming. And thus one man makes a vortex all round and steadies the earth by the heaven; another gives the air as a support to the earth, which is a sort of broad trough. Any power which in arranging them as they are arranges them for the best never enters into their minds; and instead of finding any superior strength in it, they rather expect to discover another Atlas of the world who is stronger and more everlasting and more containing than the good;- of the obligatory and containing power of the good they think nothing; and yet this is the principle which I would fain learn if any one would teach me. But as I have failed either to discover myself, or to learn of any one else, the nature of the best, I will exhibit to you, if you like, what I have found to be the second best mode of inquiring into the cause.

I should very much like to hear, he replied.

Socrates proceeded: I thought that as I had failed in the contemplation of true existence, I ought to be careful that I did not lose the eye of my soul; as people may injure their bodily eye by observing and gazing on the sun during an eclipse, unless they take the precaution of only looking at the image reflected in the water or in some similar medium. So in my own case, I was afraid that my soul might be blinded altogether if I looked at things with my eyes or tried to apprehend them by the help of the senses. And I thought that I had better have recourse to the world of mind and seek there the truth of existence. I dare say that the simile is not perfect-for I am very far from admitting that 
he who contemplates existences through the medium of thought, sees them only "through a glass darkly," any more than he who considers them in action and operation. However, this was the method which I adopted: I first assumed some principle which I judged to be the strongest, and then I affirmed as true whatever seemed to agree with this, whether relating to the cause or to anything else; and that which disagreed I regarded as untrue.

\section{AN ILLUSTRATION OF SOCRATES'S METHOD OF SHOWING UP IGNORANCE 16}

[Socrates speaks:]

By the gods, Meno, be generous, and tell me what you say that virtue is; for I shall be truly delighted to find that $I$ have been mistaken, and that you and Gorgias do really have this knowledge; although I have been just saying that I have never found anybody who had.

Meno-There will be no difficulty, Socrates, in answering your question. Let us take first the virtue of a man-he should know how to administer the state, and in the administration of it to benefit his friends and harm his enemies; and he must also be careful not to suffer harm himself. A woman's virtue, if you wish to know about that, may also be easily described: her duty is to order her house, and keep what is indoors, and obey her husband. Every age, every condition of life, young or old, male or female, bond or free, has a different virtue; there are virtues numberless, and no lack of definitions of them; for virtue is relative to the actions and ages of each of us in all that we do. And the same may be said of vice, Socrates.

${ }^{16}$ From the Meno of Plato, beginning on p. 71 D. Jowett's translation. 
Soc.-How fortunate I am, Meno. When I ask you for one virtue, you present me with a swarm of them, which are in your keeping. Suppose that I carry on the figure of the swarm, and ask of you, What is the nature of the bee? and you answer that there are many kinds of bees, and I reply: But do bees differ as bees, because there are many and different kinds of them; or are they not rather to be distinguished by some other quality, as for example beauty, size, or shape? How would you answer me?

[After a little further questioning, Socrates succeeds in showing Meno that what is wanted is not an enumeration of different virtues, but a common definition of virtue.]

Men.-Will you have one definition of them all?

Soc.-That is what I am seeking.

Men.--If you want to have one definition of them all, I know not what to say, but that virtue is the power of governing mankind.

[Socrates then leads Meno to confess that this cannot describe the virtue of all, of children, e.g., and slaves, and, indeed, that it cannot describe any man's virtue, unless we add the words justly and not unjustly, which would introduce a vicious circle. Meno then enumerates the different recognized virtues, courage, temperance, etc. But this brings back the difficulty of his first answer. So he makes another attempt:]

Men.-Well, then, Socrates, virtue, as I take it, is when he, who desires the honorable, is able to provide it for himself; so the poet says, and I say too:

Virtue is the desire of things honorable and the power of attaining them.

[Socrates makes Meno admit that all men really desire 
the honorable, so that nothing is left of his definition but "the power of attaining it"; and to make this virtue, we must again introduce the qualification, "of attaining it with justice," which once more lands us in a circle. In despair Meno exclaims:]

Men.-O Socrates, I used to be told, before I knew you, that you were always doubting yourself and making others doubt; and now you are casting your spells over me, and I am simply getting bewitched and enchanted, and am at my wits' end. And if I may venture to make a jest upon you, you seem to me both in your appearance and in your power over others to be very like the flat torpedo fish, who torpifies those who come near him and touch him, as you have now torpified me, I think. For my soul and my tongue are really torpid, and I do not know how to answer you; and though I have been delivered of an infinite variety of speeches about virtue before now, and to many persons-and very good ones they were, as I thought-at this moment I cannot even say what virtue is. 


\section{SOCRATES'S DEFENCE OF HIMSELF AS RE- PORTED BY PLATO IN THE APOLOGY}

What impression my accusers have made upon you, fellow-Athenians, I cannot say. For my part, I came near forgetting who I was; they spoke so plausibly. Yet there was scarcely a word of truth in what they said. But of the many lies they told there was one which astonished me most of all. I mean the one where they told you you would have to be on your guard lest I deceive you, because I am a clever speaker. They did indeed seem to me most brazen-faced, not to be ashamed to say that, when they were sure to be confuted by me the moment I opened my mouth and exhibited myself as anything but a clever speaker;-unless, indeed, they mean by "clever speaker" one who speaks the truth. If that is what they mean I am ready to confess that I am eloquent, though not after the fashion of their eloquence.

Well, as I was saying, my accusers have spoken scarcely a word of truth. From me, however, you shall hear the whole truth. But, Athenians, you will not hear a speech like theirs, carefully constructed, and decked out with fine words and phrases. Far from it. I shall speak without preparation, in the words that come first to my lips. For I am sure that my cause is just. Let no one expect any different course, for it would surely be unseemly that at my time of life I should 
come before you forging arguments like a callow youth. But there is one favor, Athenians, that I do most earnestly request of you. If in defending myself I use the same words I am accustomed to use in the market-place, at the tables of the money changers, and elsewhere, where many of you have heard me, do not be surprised, and do not interrupt me for that. The fact is, I am seventy years old and this is the first time that I have appeared in court, and so I am altogether a stranger to your manner of speech. Were I in truth a stranger you would, I am sure, pardon me for speaking in my native dialect and in the way that use had made familiar. And so now I beg that you will look upon me in that light, and grant this request, which I think I have a right to make: Pay no heed to my manner of speaking, which may or may not be good; but look to this only, give your undivided attention to this: Is what I say right, or is it not? That is what makes an excellent judge, as speaking the truth makes an excellent orator.

In the first place, fellow-A thenians, it is but right that I should defend myself against my old, old accusers, and answer their false charges. After that I will take up the charges of my present accusers. For my accusers are many, and now full many a year they have been accusing me falsely to you. It is these old accusers that I fear, rather than Anytus and his accomplices, formidable though they be. But, my friends, the old accusers are the more formidable, for they got hold of most of you when you were mere boys and poured into your ears their false charges against me, persuading you that there is one Socrates, a wise man, who speculates about the heavens above and pries into all the secrets of the earth beneath, and who makes the worse appear 


\section{SOURCE BOOK IN ANCIENT PHILOSOPHY}

the better reason. The men who have been spreading that tale are, fellow-Athenians, the accusers whom I fear. For their hearers suppose that persons who pursue such investigations do not even believe in gods. Then, too, those accusers are many, and they have been at it a long while, and they got a hearing at a time when you would be most easily persuaded, for you were mere boys, some of you just crossing the threshold of youth. And the case went against me by default, for there was none to answer their charges. And the most absurd part of it is that I do not even know their names and cannot tell you who they are-except in the chance case of a writer of comedies. All these men who, through envy or malice, persuaded you,-and some of them quite likely sought to persuade others because they themselves had first been persuaded,- - these are the accusers it is hardest to answer. For I cannot call any one of them into court to crossexamine him. I must defend myself exactly as if I were fighting shadows, and cross-examine where there is none to answer.

Assume with me, then, that my accusers are of two kinds, as I was saying: those who have brought the present charge, and my old time accusers whom I've just been describing. And by your leave I'll answer my old accusers first, for you heard them first, and much oftener than the rest. Well, I must make my defence, fellow-Athenians, and see if I can clear away in the short time at my disposal, the prejudice which you have had against me for many a year. Would that might be the result, if so it is best for you and for me; would I might succeed in my defence! However, let the issue be as God wills. In obedience to the law I must now make my defence. 
Let us begin at the beginning then and ask, What is the charge that has created the prejudice against me which Meletus is relying on in bringing me to trial? Just what is the slander my enemies have been spreading? Let us word their affidavit, as if their charge had been brought before a court in regular form. It would read something like this: "Socrates is a wicked man. $\mathrm{He}$ is a meddlesome person who pries into the secrets of earth and of heaven, a man who makes the worse appear the better reason; and he teaches other men to do the same things." So it runs. It is what you yourselves have seen in the comedy of Aristophanes, where he represents a certain Socrates swinging about in a basket and declaring that he is walking on air and drivelling on at a great rate about matters concerning which I don't make the slightest pretence of having any knowledge whatever. I speak with no intention of disparaging such knowledge, if any one has wisdom like that. I trust I may not be brought to trial by Meletus on so grave a count as that. But the truth is, fellowAthenians, I have nothing to do with physical speculations. I can furnish plenty of witnesses on this point from your own number. I ask those of ycu who have heard me,-and that is certainly a goodly number,to speak to your neighbors and tell them whether they have ever heard me saying anything whatsoever about such subjects. ... There! That answer will show you that the other charges current about me are of the same stripe.

No, there is no truth in any of these charges. And if you have heard any one say that I set myself up as a teacher of men and exact a fee for my services, there's no truth in that either. Not that I don't think it would 
be a fine thing to be able to teach men, as Gorgias of Leontium does, or Prodicus of Ceos, or Hippias of Elis. Any one of them can go into any city he likes and persuade the young men to forsake the society of their fellow-citizens, from whom they could choose their companions at will and without bribes, and to associate with him and to pay him for the privilege, and be only too glad to do so. And I've just heard that there is another wise man, a Parian, who has lately come to town. The other day I ran across Callias the son of Hipponicus, a man who has spent more money on the Sophists than all the rest put together. Knowing he had two sons I said to him: "Callias, if your sons had been colts or calves we should have no difficulty in hiring a trainer who was likely to bring out all the perfections that belong to their nature: we should get some skilful groom or farmer. But now, seeing that they are human beings, whom do you intend to put in charge of their training? Who is there that has the knowledge of that kind of excellence, the excellence of the man and of the citizen? I don't doubt, having sons, you've considered the question. Is there any such person?" "Yes, indeed, there is," he replied. "Who is he," I said, "and where does he hail from, and what's his fee?" "His name is Evenus," he replied, "and he comes from Paros, and he charges five minæ." And I thought to myself, happy is Evenus, if he really has this wisdom, and sells it so cheap. Had I such wisdom I should be fairly puffed up with pride. But the fact is, fellow-Athenians, I have it not.

Here perhaps some of you will reply: But, Socrates, what is this occupation of yours? Whence come these calumnies? Surely all this rumor and talk would never 
have arisen had you not been different from other men. You must have been engaged in some very unusual pursuit. Tell us, then, what it is, that we may not be guilty of judging you off-hand. That, I take it, is a fair challenge; and, if you will give me your attention, I'll try to explain to you what has caused the calumny and given me this reputation. I am afraid some of you will think I am trifling; but, rest assured, I will simply tell you the whole truth. Fellow-Athenians, I have acquired this reputation simply because of a certain kind of wisdom which I do possess. You ask, And what kind of wisdom, pray, is that? I answer, The kind that is, I think, attainable by man. It is just possible $I$ really am wise in that way; whereas the men of whom I was just speaking are wise with what may perhaps be called a superhuman wisdom. I don't know how else to describe it, for I don't pretend to have it myself. No, and whoever says that I do, lies, and is trying to slander me. And I beg of you, fellow-Athenians, that you will not hoot at me even if you think what I am about to say very arrogant; for the words I shall speak are not my own. I shall bring you as their author one who is worthy of your confidence; I shall summon the god of Delphi to testify of my wisdom, whether I have any, and of what sort it is. You remember Chærephon, don't you? He was my comrade from his youth up. And most of you have had him for a comrade; for he went into exile with you, and with you he returned. And of course you remember what sort of a man he was, how impetuously he threw himself into everything he undertook. Well, on one occasion, he went to Delphi and actually had the temerity to put this question to the oracle,-and once more, friends, I beg you not to 
cry out against me,-he asked if there was any one wiser than I. Now the Pythian priestess answered that there was no man wiser. Chærephon is dead, but his brother here will bear witness to the truth of what I say.

Now observe why I tell you this. It is because I mean to show you the origin of the prejudice against me. When I heard the response of the oracle, I said to myself: Whatever does the god mean? What is the explanation of his riddle? For I well know that I am not a wise man,-not in the least. What then could he have meant by saying that $I$ am the wisest of men? He certainly didn't tell a lie: he is a god and couldn't do that. For a long time I puzzled over his meaning. Then, after much deliberation, I hit upon this way of finding it out. I went to one of the citizens who was in high repute for his wislom, thinking that there, if anywhere, I could prove the response wrong; and meaning then to go to the oracle and say: "You said I was the wisest of men: lo! here is a wiser." Well, I examined the man,-I needn't mention his name: he was a politician -and this was my experience with him. As I talked with him it became apparent that while he passed for a wise man in the eyes of a great many persons, and most of all in his own eyes, he was not wise at all. And then I tried to show him that he was not wise, though he fancied that he was. The result was, he hated me for it; and many of those who were standing by hated me too. And as I walked away I thought to myself, "I am wiser than that man. Probably neither of us knows anything very much worth while; but he thinks that he knows, when in reality he does not; I neither know nor think that $I$ know. On this small point at any rate $I$ seem to have the best of him: I do not fancy that I know when 
in reality I am in ignorance." And then I went to another man, who was held in still higher repute for his wisdom, and he taught me the same lesson. And there again I made an enemy of him, and of all of his friends. Well, then, I went to one man after another. I saw that I was making enemies all the while; and I was sorry for that, and feared the result. Still, I couldn't help it; I had to put the command of God above every other consideration. So, in my search for the meaning of the oracle, I must make the rounds, going to all who were reputed to be in any way wise. And I swear to you, fellow-Athenians, by the dog of Egypt I swear,-for I must tell you the truth,- this was the upshot of my divinely appointed quest. The men held in highest esteem for their wisdom proved to be just about the most lacking in it; while others who are looked down upon as people of the common sort were really wiser than they.

Now I must tell you the tale of my wanderings, of the Herculean labors I endured, only to find in the end that the oracle was irrefutable. After I had made trial of the politicians I went to the poets, tragic, dithyrambic, and the rest, thinking that there I should be flagrantly trapped in my ignorance. So I would take up their poems upon which they had apparently bestowed most pains, and would ask them what they meant, hoping that thereby I might learn something from them. Well, my friends, I am almost ashamed to tell you the truth, but I can't help it. The fact is, there is hardly a person present who could not discuss the works of the poets better than the poets themselves. So it didn't take long to discover that the poets, in making their poems, are guided, not by wisdom, but by a sort of divine frenzy like that which possesses the prophets and the sooth- 


\section{SOURCE BOOK IN ANCIENT PHILOSOPHY}

sayers. They too say many beautiful things without knowing the meaning of what they say. It was clear to me that the poets had come under some such spell. And at the same time I observed that, because of their skill in poetry, they fancied themselves the wisest of men in other matters too, which they didn't know at all. So as I went away I thought to myself that I had the same advantage over them that I had over the politicians.

Last of all I went to the artisans. I was well aware that I knew nothing of any consequence, and I was sure that I should find them possessed of much admirable knowledge. And I was not mistaken about this: they did know things I am ignorant of, and, in so far, were wiser than I. But, fellow-Athenians, I found that even the skilled artisans made the same mistake as the poets. Every man of them, because he was skilled in his particular craft, fancied himself mighty wise in other matters,-and matters of the greatest importance; and this fault of theirs cast their wisdom in the shade. And so I asked myself, on behalf of the oracle, whether I would rather remain as I am, having neither their wisdom nor their ignorance, or have their wisdom together with their ignorance. And the answer I made to myself and to the oracle was: "I am better off as I am."

It is this inquisitorial task, fellow-Athenians, that has made me so many enemies of the most fierce and bitter kind. It is this that has given me the name of "wise man," and that is responsible for all their calumnious charges. For the bystanders always think that I myself possess the wisdom that I show to be lacking in others. But, my friends, I suspect that God alone is truly wise, and, by that oracular response, he meant to say that our human wisdom is of little or no worth. 
Apparently he wasn't speaking of me, Socrates. I think he just used my name, and took me for an illustration, as if he would say to mankind: "He is wisest among you who, like Socrates, has found out that in truth his wisdom is worth nothing at all." And so I still go about, obedient to God's command, probing and testing any one whom I take to be wise, whether he be a citizen or a stranger. And whenever I find that he is not wise, I show him that he is not, and thereby serve Apollo. This occupation has kept me so busy that I have had no time to take any part worth mentioning in public affairs, or even to look after my private interests. I am in deep poverty because of my service to God.

And besides all this (there is another reason for my unpopularity). The young of the richer class, who have a lot of spare time, follow me about of their own accord, and take delight in hearing men cross-examined. And they often imitate me themselves, and try their hand at cross-examining others. And I suspect they find no end of men who think they know a great deal, when in fact they know precious little. The result is, when their sham wisdom has been shown up, they get angry with me rather than with the young men, and vow, "That fellow Socrates is the plague of the town, and he corrupts the youth." And if any one asks them, "How? What does he do? What does he teach?" they do not know and have nothing to say. But, in order not to seem at a loss, they repeat the old stock charges made against all philosophers,--Prying into things up in the clouds or under the earth, not believing in gods, and making the worse appear the better reason. I can readily believe that they would scarcely relish telling the truth, which is that they have been convicted of lay- 
ing claim to a wisdom they do not possess. And I don't doubt they have been filling your ears this many a day with their bitter accusations; for there are lots of them, and they are energetic, and keen for notoriety, and they speak plausibly, and they are all lined up against me. This is the reason why Meletus and Anytus and Lycon have attacked me. Meletus is taking up the quarrel on behalf of the poets, Anytus on behalf of the craftsmen and politicians, Lycon on behalf of the rhetoricians. And so, as I remarked at the outset, I should be surprised if I were able in the short time at my disposal to remove a prejudice that has taken such deep hold upon you. There, fellow-Athenians! I have given you the plain, unvarnished truth, and the whole truth. And yet I am tolerably sure that it is just this my bluntness of speech that makes me enemies. That indeed is a proof that I am telling you the truth, and that the prejudice against me and its causes are as I have said. And if you will look into this matter, now or at any future time, you will find that it is so.

Let this suffice for my defence against the charges brought by my earliest accusers. I will next attempt to reply to Meletus,-_"noble patriot," as he styles himself,- and to my later accusers. Let us assume them to be a different set of accusers, and let us once more frame the indictment. It runs something like this: Socrates is guilty, it says, in that he corrupts the youth, and does not believe in the gods of his country, but has other and strange divinities of his own. So runs the charge. Let us examine it point by point. The first count is, that I am guilty in that I eorrupt the youth. But for my part, fellow-Athenians, I charge that Meletus is the culprit, in thus mixing jest with earnest, and lightly bringing 
men to trial, and pretending to be very earnest and very solicitous about matters to which he has never given a moment's thought. And I will try to make it as plain to you as it is to me that such is the case.

"Come, Meletus, take the stand and answer my question. Is it not a fact that you have very much at heart the improvement of the youth?"

"It is."

"Well, then, tell the judges who it is that improves them. You must know, for you care so much about it. You have discovered, as you say, that I am their corrupter, and are bringing me to trial on that charge. Come, name the man who is their improver, tell the judges who he is. You see, Meletus, you are silent; you have nothing to say. And yet don't you think that this is disgraceful? Doesn't your silence sufficiently prove the truth of what I was just saying, that you have never given this matter a moment's thought? Speak up, my good sir, who is it that makes the young men better?"

"The laws."

"But, most noble Meletus, that was not what I asked. I want to know who the man is who makes them better, assuming, of course, that he has to begin with a knowledge of the laws."

"The men before you, Socrates,-the judges."

"What do you mean, Meletus? Are they able to instruct the young, and do they improve them?"

"Certainly."

"All of them, or only some of them?"

"All of them."

"By the goddess Hera, this is good news indeed. There is a regular host of improvers of youth. And 
how about the audience? Do they improve them too?"

"They do."

"And the senators?"

"The senators, too."

"Well, then, take the members of the assembly. Perchance they corrupt them. Or do they, too, without exception, make them better?"

"They, too, make them better."

"Then apparently all the Athenians, excepting only me, make the young men fair and virtuous. I am their sole corrupter. Is that your meaning?"

"Most emphatically it is."

"Truly you have found me in a sorry plight. But tell me, in the case of horses, does it strike you that it is like that,-I mean, that some one man does them harm while all the rest do them good? Is not the truth precisely the contrary, - that one man, or at most a few, namely the skilled horse-trainers, do them good, while the rest, if they have anything to do with them, or try to break them in, do them harm? And isn't it this way, Meletus, not only with horses, but with all other animals too? Of course it is, whether you and Anytus say yes or no. It were indeed a great piece of good fortune for the young men if they had but one corrupter, and if every one else did them good. But the truth is, Meletus, you have clearly proved that you have never given the slightest thought to the young. You make your carelessness quite evident; you show that you have never paid the slightest heed to the matters about which you are prosecuting me.

"Now, once more, Meletus, will you be good enough to answer a question? Is it better to live among bad 
citizens or among good ones? Answer, my friend. That is surely not a hard question. Do not the bad citizens do their neighbors harm, and the good citizens do them good?"

"Certainly."

"And is there any one who would deliberately prefer to be harmed rather than to be benefited by those with whom he associates? Answer, my friend, the law requires you to. Does any one want to be injured?"

"Of course not."

"Well, then, are you bringing me to trial for corrupting the youth and making them worse intentionally, or for doing so unintentionally?"

"For doing so intentionally."

"What, Meletus, are you so much wiser than I,-you so young, and I so old,- - that you have made the discovery that evil men always do evil to their neighbors, and good men good, whereas I, forsooth, have fallen to such a depth of ignorance as not to be aware that if I make a rogue of a fellow-citizen he is likely to do me harm? And so I commit this great wrong intentionally, as you aver? Meletus, you will never convince me of that, or any one else, I trust. No, either I do not corrupt the young men at all, or I do so unintentionally; so that in either case your statement is false. And if I corrupt them unintentionally, then of such unintentional misdeeds the law takes no cognizance. You ought rather to have taken me aside and taught me and admonished me. For it is plain that I shall stop sinning unintentionally when I have been taught better. But you have always avoided me; you didn't want to instruct me. And now you are bringing me into court, where the law brings men for punishment, not for instruction." 


\section{SOURCE BOOK IN ANCIENT PHILOSOPHY}

Well, fellow-Athenians, you must find it quite evident by this time that, as I was saying, Meletus has never troubled himself a bit about these matters. "However, tell us, Meletus, in what way, according to you, I corrupt the youth. Or is it plain enough from the indictment you have brought, that it is by teaching them not to believe in the gods our country recognizes, but in other and strange divinities? You say, do you not, that this is the teaching by which I corrupt the youth?"

"Precisely; and I say it most emphatically."

"Then, Meletus, in the name of those very gods of whom we are speaking, tell me and my judges here a little more clearly what you mean. I can't quite make out whether you accuse me of teaching them to believe in some gods-in which case I myself believe in gods and am not a downright atheist. I don't offend in that way. My offence is rather that I believe in strange divinities, and not in the gods of my country. Or whether you accuse me of not believing in gods at all, and of making atheists of others too."

"I mean that you are a downright atheist."

"My good fellow, what makes you say that? Do you mean to say that I don't even believe, like other men, that the sun and the moon are gods?"

"Judges, I swear, by heaven I swear, he does not; for he says the sun is a stone and the moon earth."

"My dear Meletus, you must think you are prosecuting Anaxagoras! Have you such a poor opinion of the judges, and do you think them so unlettered as not to know that the works of Anaxagoras of Clazomenæ are chock full of those doctrines? So the young men actually learn those doctrines from me, do they? when for a drachma at most they can often hear them at the theatre, 
and laugh Socrates to scorn if he pretends they are his, - such very odd doctrines, too. No, but honestly, Meletus, do you really think I don't believe in any god at all?"

"I do. I swear by heaven that you do not believe in any god at all."

"Nobody believes you, Meletus. Indeed, I feel sure you don't believe yourself." It seems to me, fellowAthenians, that my accuser is an insolent and impertinent young man, and that he has brought this indictment in a spirit of sheer insolence and youthful audacity. He is like a man who tries to pose you by putting a paradox. And he is saying to himself: Will the wise Socrates see that I am jesting and contradicting myself, or shall I succeed in befuddling him and the rest of my hearers? For he plainly contradicts himself in the indictment, just as if he were to say: Socrates is a wicked man because he does not believe in gods, but believes in gods.

If you will follow me, friends, you will see how I find him thus inconsistent. "Answer me, Meletus." And I hope that you, my judges, will remember the request I made at the beginning, and quietly suffer me to talk in my usual way.

"Is there any one in the world, Meletus, who believes there are things human, while at the same time not believing there are any humans?" I wish, friends, that he would answer without these continual interruptions. "Is there any one who believes that horsemanship exists, but no horses; flute-playing, but no flute-players? There is no one, my dear man; I'll tell you and the judges that, if you don't choose to answer. But at least answer my next question: Is there any one who believes there are divine agencies, while at the same time not believing that there are divinities?" 
"There is no one."

"I am delighted that the judges have at last managed to pull an answer from you. Well, then, you say that I believe in, and teach others to believe in divine agencies -no matter whether new or old-at all events I believe in divine agencies. I have your own word for that; you swore to it in your indictment. Now, if I believe in divine agencies, surely I must of necessity believe that there are divinities. That follows, doesn't it? Well, it does. I assume from your silence that you admit that. And by 'divinities' we mean, do we not, either gods or sons of gods? Yes or no?"

"Yes, certainly."

"You admit then that I believe in divinities. Now if these divinities are a species of gods, then there is my proof that you are trifling and speaking in riddles, and are saying in one and the same breath that $I$ do not believe in gods and that I do believe in gods, inasmuch as I believe in divinities. If, on the other hand, these divinities are sons of gods, their natural sons, as it were, by nymphs or some other mortal mothers, as rumor makes them,- - why, then, let me ask you, is there any one in the world who could suppose that there are sons of gods, and at the same time that there are no gods? That would be just as absurd as to hold that there are mules, and to hold at the same time that there are neither horses nor asses! No, Meletus, you must surely have brought this indictment against me in order to make trial of me,-or else, because you couldn't find any real offence to charge me with. But you will never succeed, by hook or by crook, in persuading any one who has a scrap of intelligence, that one and the same man can believe in supernatural and divine agencies, 
and yet not believe that there are divinities, gods and heroes."

But really, fellow-Athenians, I don't think I need make a long speech in order to show that I am not guilty of the crime charged by Meletus. I have said enough for that. But it is only too true, as I remarked before, that I have made many and bitter enemies. That is what will convict me, if I am convicted,- not Meletus, nor Anytus, but the prejudice and ill-will of the multitude. These things have convicted many another innocent man, and they will, I dare say, continue to do so: there is no fear that I shall be the last.

Possibly some one will here interpose: Are you not ashamed, Socrates, to have led a life of such a kind that it has brought you into imminent danger of death? To him I should say, and my answer would be just: You are wrong, my friend, if you think a man who is good for anything at all ought, when he acts, to be calculating his chances of life and death, instead of paying heed to this, and this alone: Is he doing right or wrong, are his deeds the deeds of a good man or of a bad? Why, your theory would make worthless men of all the heroes who fell at Troy, and especially of Thetis's son who despised danger when the alternative was disgrace. For when he was bent on slaying Hector his goddess mother spoke to him in words, I believe, something like this: "My son, if you avenge the death of your comrade Patroclus, and slay Hector, you yourself will die. For straightway after Hector's death," said she, "your doom awaits you." He listened to her warning, and, scorning danger and death, but greatly dreading to live a coward's life, with his friend unavenged, he exclaimed: "Let death come, but let me first punish the murderer of my friend, that I may 
not remain here by the beaked ships the scorn of men, a mere cumberer of the earth." You don't suppose he had any anxiety about danger and death? And, fellowAthenians, this is just as it should be. In whatever post a man finds himself, whether he has chosen it, thinking it the best, or whether he has been placed there by his superior, there he ought, I am sure, to remain, whatever the risks, taking no thought of death, or of anything else save disgrace.

Fellow-Athenians, when the generals whom you had chosen to place over me assigned me my post at Potidæa, at Amphipolis, and at Delium, I remained where they had put me, facing death like any other man. Strange indeed then would be my conduct if, through fear of death or of anything else, I were now to desert the post where God has placed me, as I am firmly persuaded that he has, commanding me to spend my life in the search after truth and in examining myself and others. Yes, that would indeed be strange. Then surely I might with justice be brought to trial on the charge of not believing in the gods, for I should be disobeying the oracle through fear of death, fancying myself wise when I am not. For to fear death means simply to think you are wise when you are not; for it is equivalent to thinking you know what you do not know. No one knows what death is, whether it be not the greatest blessing that can befall a man. Yet men fear it as if they knew for certain that it is the greatest of evils. And isn't this just ignorance of that disgraceful sort, thinking we know what we do not know? Here too, friends, very likely I differ from most men in this, and if I should venture to say that I am wiser than another in anything it would be in this, that having no clear knowledge of the 
other world I do not delude myself into thinking that I have. But this I do know, that to do wrong, and to be disloyal to a superior-whether God or man-is base and dishonorable. And I shall always fear and flee from the evils that I know to be evils, rather than from reputed evils which, for all I know, may be blessings.

And so if you should let me go free now, notwithstanding the plea of Anytus that either you ought never to have brought me to trial at all, or, having done so, you cannot possibly do anything but put me to death, because, as he tells you, if I escape now your sons will all forthwith practise what Socrates teaches and be utterly ruined,-if you were to say to me, in view of his argument: "Socrates, this time we shall not listen to Anytus. We shall let you go free, but on this condition, that you give up this quest of yours and philosophize no more. If you are caught at it again you shall die." If, I say, you were to let me off on these terms, I should reply: "Fellow-Athenians, I love you, I am devoted to you; but I shall obey God rather than you. And while breath and strength hold out I shall never cease from pursuing wisdom, or from exhorting any one of you whom I may meet, speaking frankly to him, and saying in my usual fashion: "My friend, as a citizen of Athens, a city greatest and most famous for its wislom and power, are you not ashamed to be so greedy for wealth and name and fame, so careless and so thoughtless about wisdom and truth and the perfecting of your own soul?" And if he contradicts me, and says that he does care about these things, I shall not take him at his word and straightway let him go, but I shall question him and cross-question him and test him, and if I find that he is not virtuous, but only says that he is, I shall rebuke 
him for prizing least what is of most value and prizing more what is of less worth. This service I shall render to every one I meet, young or old, citizen or alien, but especially to you citizens, for you are more nearly akin to me. Be assured, this is God's command. And I hold that no greater blessing has ever befallen you in Athens than this my service to God. For I spend all my time going about among you, persuading you, old and young alike, not to be so solicitous about your bodies or your possessions, but first of all, and most earnestly, to consider how to make your souls as perfect as possible; and telling you that wealth does not bring virtue: rather, virtue brings wealth and every other human good, private or public. If then by such teaching I corrupt the youth, these must be pernicious doctrines. But if any one asserts that I teach anything else than this he lies. Wherefore, Athenians, either listen to Anytus or do not, acquit me or not; but rest assured, I shall never alter my way of life-no, not though many deaths await me.

Do not interrupt me, fellow-Athenians; stand by me in the request I made that you should listen patiently to my words. For I think that it will be to your advantage to hear them. I hesitate to speak, for the fact is what I am going to say is pretty sure to make you shouting mad; but you simply mustn't let it do so. If you put me to death, my character being such as I tell you it is, you may be very sure that you will do greater harm to yourselves than to me. Neither Meletus nor Anytus could possibly do me any real injury; it isn't in their power to do so; for I take it Providence will never permit a bad man to harm one better than himself. Meletus may indeed compass my death, he may have me 
banished or deprived of my rights as a citizen. And very likely he, and other men too, imagine that these things are very great evils. I do not. Nay, I hold that it is a much greater evil to do what he is doing now,trying to put a man to death unjustly.

So, fellow-Athenians, I am not making the present defence just to save my own life, as might be supposed. Not at all. I am doing so to save you from sinning against God and rejecting his gift to you by condemning me. For if you kill me you will not easily find another man who like me will, at God's bidding, literally stick to the state like a gadfly to a horse,-if you'll pardon a rather ludicrous comparison. For the state is like a huge horse of noble breed, but rather sluggish from his very size, and needing the gadfly to wake him up. And I think God has given me to the state to play the part of just such a gadfly, and I keep lighting upon you any and everywhere, and spend the livelong day waking you up, and persuading you and rebuking you. My friends, you will not easily find another man like that, and if you take my advice you will spare my life. However, it is quite possible that you are irritated, like drowsy men when they are awakened, and that you will listen to Anytus and crush this gadfly, lightly putting me to death. Then you could sleep on in peace for the rest of your days,- - unless God in his care for you were to send you another tormentor. That it is God himself who has given me to the state you can see from this: no mere human motive would account for my having neglected all my own affairs, allowing my private interests to go to ruin during all these years, while at the same time always looking after your welfare, going to you all, one by one, like a father or an elder brother, and urging 
you to pay heed to virtue. If I had taken a fee for my exhortations and made any money out of them my conduct could be accounted for. But now you yourselves see that my accusers, though they have accused me of everything else with such effrontery, hadn't the face to try to show that $I$ ever either asked or received any fee. I offer you, I fancy, in my actual poverty an incontrovertible witness to the truth of my words.

Well, very likely it has the air of inconsistency to be going about in private offering you my advice and busying myself with your affairs, while not venturing to come forward in public in your assemblies to give the state the benefit of my advice. The reason for this you have heard me give over and again, and in divers places: a certain supernatural and divine sign comes to me,and it is this that Meletus has caricatured in his indictment. I have had it ever since I was a child. It is a sort of voice that speaks to me, and whenever I hear it it always dissuades me from doing what I was on the point of doing, but never urges me on. This is what forbids my taking part in public life; and it does so wisely, I think. For I am very sure, fellow-Athenians, that had I attempted to take part in public life I should have perished long ago, without doing any good either to you or to myself. And don't be angry with me for telling the truth, but the fact is that there is no man whose life will be safe, here or anywhere else, if he sets himself genuinely in opposition to the multitude, and tries to prevent the many unjust and lawless deeds done in the state. No, he who would really battle for the right must do so in private and not in public life if he means to live even for a short season.

I will give you a striking proof of this, not words but, 
what has more weight with you,- - deeds. Listen, and I'll tell you some of my experiences, that you may be convinced that I would give way to no man through fear of death, although, for not giving way, I should have to die on the spot. The tale I am going to tell is common enough and may weary you, but it is true. I never held any office in the state, Athenians, except that of senator. And it chanced that my tribe, Antiochus, had the presidency at the time when you proposed to try in a body, and contrary to the law, as you all afterward realized, the ten generals who had not rescued their men after the battle of Arginusæ. On that occasion I was the only one of the presidents who opposed your illegal action and voted against it. In spite of your orators, who were ready to arrest me and lay an information against me, in spite of your shouts and your threats, I deemed it my duty to face every risk, with the law and the right on my side, rather than join you in your iniquitous designs through fear of imprisonment and death.

This happened while the government was still a democracy. And again, when the oligarchy was established, the Thirty summoned me and four others to the council chamber and ordered us to bring Leon the Salaminian from Salamis to be put to death. You know that was a way they had; they gave orders like that to a great many other men too, for they wanted to implicate as many as possible in their guilty deeds. However, there again I showed, not by my professions but by my practice, that, if you'll pardon the slang, I didn't care a fig for death; my great and only care was to do nothing wrong or impious. Strong as was the tyranny of the Thirty, it was not strong enough to frighten me into 


\section{SOURCE BOOK IN ANCIENT PHILOSOPHY}

doing wrong. When we left the council chamber the four others went over to Salamis and brought Leon back, but I went off home. No doubt I should have lost my life for my disobedience had not the government of the Thirty been overthrown soon afterward. You can have plenty of witnesses to the truth of what I say.

Do you imagine for a moment that I should have survived all these years had I taken part in public affairs and, like an honest man, always stood for the right and, as in duty bound, made that my chief concern? Certainly not, fellow-Athenians,--nor I nor any other man. Throughout my whole life, whenever I have had occasion to take part in public affairs, you will find me always the same, and the same in private life too, never swerving from the path of justice through complaisance to any man,- to any of those whom my traducers call my disciples, or to any one else. The fact is, I never was any man's teacher; but if any one, young or old, wants to hear me talking, as I pursue my mission, he is welcome to do so. And I do not talk for a fee and refuse to talk unless paid. I am at the service of rich and poor alike. Any one may question me, or, if he prefers, answer my questions, and may listen to what I say. And whether he turns out to be a good citizen or otherwise, I cannot rightly be held responsible, for I have never taught or promised to teach any one of them anything. And if any one says he has ever learned or heard anything from me in private other than what all the rest of you have heard you may surely put him down for a liar.

But, you will ask, why is it then that people like to spend so much time in my company? You have my answer already, fellow-Athenians. I have told you the whole truth. They like to hear me cross-examining men 
who think they are wise when they are not. You know, it is rather amusing. This mission, as I say, has been assigned to me by God who has made his will known through oracles, dreams, and in every other way by which the divine providence has ever imposed any duty upon man. This is the truth, Athenians, and may easily be proved. For if I am corrupting some of the young men, and have corrupted others, surely some of them ought to come forward to-day as my accusers and take their revenge, if, now that they are grown up, they have discovered that I ever gave them bad advice in their youth. And if they themselves were unwilling to do so, some of their kinsmen-fathers, brothers, or other relatives-ought now to remember it and take their revenge if $\mathrm{I}$ had done their kinsmen any wrong. Certainly I see plenty of them here in court. First there is Crito, a man of my age and of my own deme, and there is his son, Critobulus. Then there is Lysanias of Sphettus, and there is his son, Eschines; and there is Antiphon, too, the father of Epigenes. Then here are others whose brothers have associated with me, Nicostratus, son of Theozotides, and brother of Theodotus-and Theodotus is dead so he at least cannot bind his brother to silence. And here is Paralus, son of Demodocus, who had a brother Theages; and here is Adeimantus, son of Ariston, and there is his brother Plato; and there is Eantodorus with his brother Apollodorus. And I could name many others to you. Surely, during the course of his speech, Meletus ought to have produced one of them as a witness against me. If he forgot it then, let him do so now,I will make way for him,- and let him tell us if he has any such evidence. But you will find, my friends, that, on the contrary, they are all ready to defend me,-me the 
corrupter, the man who has worked evil to those of their own household, if we are to take the word of Meletus and Anytus. To be sure, those who have themselves been corrupted might have their reason for supporting me; but the uncorrupted, their kinsmen who are already advanced in years-what reason have they for defending me, except the true and just one: they know Meletus is a liar and that I am speaking the truth.

Well, gentlemen, this, and possibly more of the same sort, is about all $I$ have to say in my defence. Perhaps there is some one among you who will be angry when he recalls how he himself, when a defendant in a case of far less importance than this, wept copiously, and begged and implored the judges, bringing his children into court and a great many others, kinsmen and friends, to arouse as much as possible your feelings of compassion; and when he finds that I shall do none of these things, although, in all likelihood, my life is at stake. And so, as he thinks of this, he may harden his heart against me, and be angry with me for this very reason, and cast his vote in anger. If there is any one of you in this case -I don't think there should be, but if there is, I think I might very properly say to him: My friend, doubtless I too have a few kinsmen, for, to borrow Homer's words, "I am born not of wood nor of stone, but of woman." And so I have kinsmen, yes, and sons, fellowAthenians - three of them. One is already a youth, the others are mere boys. Nevertheless, I will not bring one of them here, nor beg you for an acquittal. And why not? Not because I am stubborn, nor because I fail in my respect for you, fellow-Athenians. Whether or not I face death with courage is not the question now. But I think that for me, at my time of life and with my 
reputation for wisdom, whether deserved or not, to do any of those things would spell dishonor to me and to you and to the whole state. Whatever the fact, it is the commonly received opinion that Socrates is in some way superior to the general run of mankind. It were surely a disgrace if those of you who are held to excel in wisdom or courage, or in any other virtue, were to act like men whom I've often seen,-men of some reputation too,-who when brought to trial behaved in the strangest manner, as if they were convinced that it was a most terrible thing to die, and as if they expected to live forever provided you did not put them to death. I think such men bring dishonor to our state, so that any stranger would suppose that the Athenians, who excel in virtue, and who are chosen by their fellowcitizens for public offices and other dignities, are no better than women. Fellow-Athenians, it is not right for us who have any reputation at all to behave this way; and if we do, then you ought to put a stop to it. On the other hand you ought to make it plain that you will be much more likely to condemn the man who gets up these piteous farces, thereby making the city ridiculous, than the man who keeps calm.

But, my friends, apart from the question of reputation, I think it is not right to implore a judge for mercy and receive acquittal as a favor. It is one's duty to enlighten and convince him; for he sits as judge to determine what is just and not to curry favor with his verdicts. And he has taken oath to judge according to the laws, and not to favor those whom it may please him to favor. And so it is not right that we should get you in the habit of perjuring yourselves, or that you should acquire that habit, for there would be no piety in that either for 
you or for me. Therefore, fellow-citizens, do not require me to do, where you are concerned, what I hold to be neither honorable nor right nor pious, no, not at any time, and least of all when I am being prosecuted by Meletus on the charge of impiety. For I should clearly be teaching you to believe that there are no gods if I were to persuade you and were to overpower your oaths by my importunings. In my very defence I should literally be accusing myself of believing that there are no gods. But that is far from being the case. FellowAthenians, I do believe in the gods, more firmly than any of my accusers, and to you and to God I commend my cause, to be decided in the way that will prove best for you as well as for me.

[Socrates is found guilty by a vote of 281 to 220 . The penalty of death has been proposed by Meletus, and it is now Socrates's privilege to propose a counter penalty.]

Fellow-Athenians, I am not greatly displeased at the verdict you have brought in, and that for many reasons. I was quite prepared for this result. But I am greatly surprised at the way the votes were divided. I had no idea the majority against me would be so small; I expected it to be overwhelming. But now it seems that if only thirty votes had changed sides I should have been acquitted. Indeed, as it is, I think that I have escaped Meletus. And not only that; it must be apparent to all that had Anytus and Lycon not come forward to join him in the accusation he would not have obtained the fifth part of your votes, and so would have been fined a thousand drachmas.

So Meletus proposes death as the penalty. Very good. 
And what shall I propose to you, fellow-Athenians, as a counter penalty? Obviously, what I deserve. And what is that? What penalty should I suffer, what fine should I pay because I didn't spend my life in ease; because I cared not for what most men prize-making and hoarding money, military commands, speech-making in the assembly, public offices, and the conspiracies and factions of our state, thinking myself really too conscientious a man to go in for such things and live; because I didn't enter upon a career which would prevent my doing any good to you or to myself, but adopted the course that would enable me, as I have said, to do the greatest possible service to each of you individually, and tried to persuade each of you to take thought for himself and consider how he could make himself as good and as wise as possible before he took thought for his affairs, and in the same way to take thought for the state itself before concerning himself with the state's affairs, and in all cases to follow the same order in his solicitudes? What then do I deserve for such a life? Something good, fellow-Athenians, if I must really fix the penalty according to my deserts, and moreover a good such as would be suitable for me to accept. What then is a fit recompense for a benefactor who is poor and who requires leisure that he may exhort you? Fellow-Athenians, there is none that is more fitting for a man of that sort than that he be maintained in the Prytaneum at the public expense. It is far more suitable to give him such a reward than to give it to one of your number who has been victorious in a horse-race, or in a two- or four-horse chariot-race, at the Olympic games. He gives you the appearance of happiness; I give you the reality. Besides, he is not in want; I am. And so if I must propose the 
penalty which I justly deserve I should propose this: maintenance in the Prytaneum at the public expense.

Well, very likely you will think that I am saying this from sheer obstinacy, interpreting this pretty much as you did what I said about wailing and begging for mercy. But such is not the fact, Atheniains. The truth rather is that I speak as I do because I am corvinced that I never wronged any man intentionally, though I cannot convince you of that. We have had too short a time to discuss the matter. If it were the law here, as it is in other lands, that in a case where the penalty is death the trial must continue for several days, and not one only, I might have convinced you. As it is, it is not easy to do away with formidable calumnies all in a moment. I an firmly convinced that I never wronged any man, and I certainly shall not wrong myself. And I shall not accuse myself of deserving any evil, nor shall I propose anything of the sort for myself as a penalty. What fear could drive me to that? Fear lest I suffer the penalty Meletus proposes, when, as I say, I do not know whether it be a good or an evil? Would you have me propose instead things which I know to be evils? What penalty shall I propose? Imprisonment? And why should I spend ny life in prison, a slave to the Elevens successively appointed as jailers? Or shall it be a fine, with imprisonment until it is paid? But for me that would be equivalent to life imprisonment. For I have no money to pay a fine with. Or shall it be exile? Perhaps you would agree to that punishment. I must indeed be madly in love with life if $I$ am so lost to reason as not to be able to reflect that, if you who are my fellow-citizens were unable to tolerate my discussions and my arguments, and have found them so troublesome and so odious that 
you are now seeking to be quit of them, strangers will scarcely find it easy to bear with me. Far from it, Athenians, a fine life it would be for an old man like me to leave my native town and pass my days in wandering from city to city, always being driven out. For I am sure that wherever I go the young men will listen to my arguments, just as they do here. And if I drive them away they will persuade their elders to drive me away. If I do not drive them away, their fathers and kinsmen will expel me for their sakes.

But perhaps some one may say: Socrates, when you quit us, won't it be possible for you to refrain from talking and to hold your peace? This is just the point that it is most difficult to make you understand, for if I say that that means to disobey God, and that therefore I cannot hold my peace, you will not believe me, you will say that I am not speaking candidly. If on the other hand I tell you that it is also the very best thing a man can do, to be applying his reason every day to the question of virtue and to the other matters you hear me conversing about, as I examine myself and others; and if I add that the unexamined life is not worthy to be lived by man,- -you are still less likely to believe me. I am but telling you the truth, friends, though it is not easy for me to persuade you. For the rest, I have not been accustomed to think myself deserving of any evil. If I had money I should have proposed a fine as large as I could pay. That would not have hurt me any. As it is, I haven't the money for that, unless you are willing to impose a fine within the possibility of my slender means. Very likely I could pay a mina of silver. Well, I propose that.Fellow-Athenians, Plato here, and Crito, and Critobulus, bid me make it thirty minæ and offer to be my sureties. 
So I propose that amount. You will have in them ample security for the money.

[Socrates's half-ironical proposition is not accepted and the penalty of death is imposed. Socrates continues:]

You have not gained much time, fellow-Athenians, and the price you will pay is the evil name which those who wish to abuse our city will give you. They will blame you for having put to death Socrates, a wise man. For those who will want to reproach you will say that I am wise even though I am not. If you had had patience to wait for a little while you would have gained your end in the course of nature. For as you see I am already far advanced in years, and near to death. I say this not to all of you, but only to those who voted for my death. And I have something else to say to them. You may perhaps think, gentlemen, that I have been convicted because I was lacking in the kind of arguments necessary to persuade you,- that is, if I had thought it right to leave nothing unsaid or undone in order to escape punishment. Far from it. I have been convicted because I was lacking, not in argument, but in effrontery and shamelessness, and because I was unwilling to speak to you as you would have liked to have me speak, weeping and lamenting, and doing and saying many other things the like of which you have been wont to hear from other men, but which, as I have said, are unworthy of me. When I was making my defence I thought I ought not to do anything unworthy of a freeman just because I was in danger, and I have no misgivings now over the manner of my defence. No, I 
would far rather defend myself as I did, and die, than owe my life to a craven defence. For it is wrong for me, and for any one else, either in a lawsuit or in battle, to resort to every possible device in order to escape death. In battle it is of ten plain that a man may at least save his life by throwing down his arms and imploring quarter of his pursuers. And in other kinds of danger there are plenty of devices whereby a man may save his life, if he has the audacity to say and do any and everything. But, my friends, I suspect the difficulty is, not to escape death, but rather to escape wickedness. For wickedness runs swifter than death, and now I who am old and slow have been caught by the slower runner, while my accusers who are clever and swift have been caught by the faster runner, which is wickedness. And now I depart having been condemned to death by you. They, too, depart condemned by truth to pay the penalty of depravity and unrighteousness. I abide by my punishment; let them abide by theirs. I suppose these things are destined so to be; and I think that it is all for the best.

And now I want to prophesy the future to you who have condemned me. For I am about to die, and that is the time when men are most gifted with prophetic power. I say to you, you who have condemned me to death, that the moment I am gone punishment will overtake you, yes, by heaven, a punishment far more severe than the penalty of death which you have inflicted upon me. You have now done this thing in the belief that you are going to be free from the necessity of giving an account of your lives. I assure you that the result will be quite to the contrary. There will be many more to call you to account, men whom I have thus far been holding in check though you didn't perceive it. 
And they are younger, and will be so much the harder upon you, and you will be so much the more angry with them. For you are much mistaken if you think that by putting men to death you can keep people from reproaching you for your evil lives. That way of escape is certainly not possible, nor is it honorable. The way that is at once easiest and most honorable is, not to be silencing the reproaches of others, but to be making yourselves as perfect as you can. With this prophecy, then, I take my leave of you who have condemned me.

But with you who have voted to acquit me I would gladly converse about this thing that has happened, while the officers are busy, and before I go where I must go to die. Pray stay that long with me, my friends, for there is no reason why we should not talk together about our beliefs while we may. I want to explain to you who are my friends the meaning of what has just befallen me. For a very strange thing has happened to me, my judges -for I am surely right in addressing you as judges,-my familiar prophetic voice, the divine sign, has up to the present time always been in the habit of opposing me even in most trifling matters, when I was on the point of acting wrongly. But now you yourselves see what has just happened to me, a thing which one might think, which is generally considered, the greatest possible evil. But the divine sign did not oppose me as I was leaving my house this morning, nor as I was mounting the platform here in court, nor did it oppose me once in my speech in what I was about to say. Yet of ten on other occasions it has stopped me right in the middle of a speech. But now, in this affair, it has not opposed a single word or deed of mine. What do I take to be the 
meaning of this? I will tell you. This thing that has happened to me must be a blessing, and we who think that death is an evil are surely mistaken in our belief. I have received striking evidence of this, for it is impossible that the divine sign should not have opposed me, unless indeed I am going to fare well.

Again, look at the matter in this light too, and we discover high hopes for believing that death is a blessing. There are just two alternatives with regard to death: either the dead man has lost all power of perception, and wholly ceased to be; or else, as tradition has it, the soul at death changes its habitation, moving from its home here to its home yonder. And if there is no perception at all, and death is like a sound sleep unbroken even by a dream, then it is a wonderful gain. For I think if one were called upon to select the night in which he slept so soundly that he did not even dream, and to compare all the other days and nights of his life with that night, and to declare after careful consideration how many days and nights of his life he had passed better or more agreeable than that night, I think that no one, whether private citizen or even the great king himself, would find them very easy to count in comparison with all the rest. If then that is what death is like I for one say it is a gain, for in that case all eternity is but a single night. If on the other hand death is a journey to another world, and if the traditional belief is true that all the dead are there, what blessing could be greater than this, $\mathrm{O}$ my judges? If, on arriving in the under world, one is free from these pretended judges here, and finds the true judges who are said to sit in judgment there, Minos and Rhadamanthus and Eacus and Triptolemus, and all the other demigods who in life were themselves just- 
wouldn't that be a journey worth taking! Again, to associate with Orpheus and Musæus and Hesiod-what would you not give for that privilege! For my part I am ready to die over and over again if these beliefs are true; for I should find wondrous pleasure in the life over there, meeting with Palamedes and Ajax, the son of Telamon, or any of the other men of old who met their death through an unjust judgment. It would be no small pleasure, I take it, to compare my own experiences with theirs. And, best of all, I could spend my time examining and questioning the men over there, as I do the men here on earth, finding out which of them are wise, and which of them thinks himself wise when he is not. What would one not give, $\mathrm{O}$ my judges, to examine him who led the great expedition against Troy, or Odysseus or Sisyphus or countless other men and women who might be named? What inconceivable happiness to be with them, to converse with them, and examine them! One thing at least is certain: they do not put a man to death over there for asking questions. For the men of that world, besides being happier than we are in all other respects, are once and for all immortal, if the tales that are told are true. You too, my judges, are to face death full of hope. You ought to meditate on this truth: no evil can possibly befall a good man, in this life or after death. His interests are not neglected by the gods. And it is no mere chance that has brought him to this pass. No, I see clearly, that it is better for me to die now and be released from trouble. That is why the oracle did not once turn me back; that is why I am not at all angry with these men who have condemned me, or with my accusers. To be sure it was not with this in mind that they condemned me, or brought the accusa- 
tion against me, but because they thought to do me harm. For that indeed I may fairly blame them.

However, I have this request to make of them. When my sons grow up take your revenge on them, gentlemen; plague them just as I have plagued you, if you find them setting their hearts on riches, or on anything else more than on virtue. If they think they are something when in reality they are nothing, reproach them, as I have reproached you, for not caring for the things they ought to care for and for thinking they are worth something when they are worth nothing at all. If you do this I shall have received justice at your hands, I and my sons, too.

But the time has come for us to depart-I to die, you to live. Which of us is going to the better lot God alone clearly knows. 


\section{XI}

\section{THE LESSER SOCRATICS}

\section{ARISTIPPUS-THE CYRENAICS}

THE $^{1}$ Cyrenaics said that the feelings were the criteria of truth, that they alone could be apprehended and were not misleading. On the other hand the causes of the feelings, one and all, are incomprehensible and the source of false opinion. For whenever we experience a white color or a sweet taste we can speak without fear of being misled or refuted; but what it is that causes the feeling white or sweet, that we cannot tell.

It is ${ }^{2}$ not the man who abstains who is pleasure's master, but rather the man who enjoys pleasure without being completely carried off his feet. Just as in the case of a ship or a horse one does not show one's mastery by refraining from use, but by knowing how to direct them whithersoever he will.

But ${ }^{3}$ Aristippus was a man very quick at adapting himself to every kind of place, and time, and person, and he easily supported every change of fortune. For which reason he was in greater favor with Dionysius than any of the others, as he always made the best of existing circumstances. For he enjoyed what was before him

1 Sext. Emp. Math. Adv. VII. 191.

2 Aristippus ap. Stob. Florileg. 17, 18.

3 From Diogenes Laertius, Yonge's translation, with a few minor changes, p. 81 . 
pleasantly, and he did not toil to procure himself the enjoyment of what was not present. On which account Diogenes used to call him the king's dog. And Timon used to snarl at him as too luxurious, speaking somewhat in this fashion:

Like the effeminate mind of Aristippus,

Who, as he said, by touch could judge of falsehood.

\section{$*^{*} *$}

These ${ }^{4}$ men then who continued in the school of Aristippus, and were called Cyrenaics, adopted the following opinions: They said that there were two emotions of the mind, pleasure and pain; that the one, namely pleasure, was a moderate emotion; the other, namely pain, a rough one. And that no one pleasure was different from or more pleasant than another; and that pleasure was praised by all living things, pain avoided. They said also that pleasure belonged to the body, and constituted its chief good;... . but the pleasure which they call the chief good is not that pleasure as a state which consists in the absence of all pain and is a sort of undisturbedness, which is what Epicurus admits as such; for the Cyrenaies think that there is a distinction between the chief good and a life of happiness, for that the chief good is a particular pleasure, but that happiness is a state consisting of a number of particular pleasures, among which both those which are past and those which are future are enumerated. And they consider that the particular pleasure is desirable for its own sake; but that happiness is desirable not for its own sake, but for that of the particular pleasure. And that the proof that pleasure is the chief good is that we are from

- From Diogenes Laertius, Yonge's translation, pp. 89-91. 


\section{SOURCE BOOK IN ANCIENT PHILOSOPHY}

our childhood attracted to it without any deliberate choice of our own; and that when we have obtained it, we do not seek anything further, and also that there is nothing which we avoid so much as we do its opposite, which is pain. And they assert, too, that pleasure is a good, even if it arises from the most unbecoming causes; .... for even if an action be ever so absurd, still the pleasure which arises out of it is desirable, and a good.

Moreover, the banishment of pain, as it is called by Epicurus, appears to the Cyrenaics not to be pleasure; neither is the absence of pleasure pain, for both pleasure and pain consist in motion; and neither the absence of pleasure nor the absence of pain is motion. In fact, absence of pain is a condition like that of a person asleep. They say also that it is possible that some persons may not desire pleasure, owing to some perversity of mind. They hold that the pleasures and pains of the mind do not all originate in pleasures and pains of the body, for pleasure of ten arises from the mere fact of the prosperity of one's country, or from one's own; but they deny that pleasure is caused by either the recollection or the anticipation of good fortune-though Epicurus asserted that it was-for the motion of the mind is put an end to by time. They say, too, that pleasure is not caused by simple seeing or hearing. Accordingly we listen with pleasure to those who give a representation of lamentations; but we are pained when we see men lamenting in reality. And they called the absence of pleasure and of pain intermediate states; and asserted that corporeal pleasures were superior to mental ones, and corporeal sufferings worse than mental ones. And they argued that it was on this principle that offenders were punished with bodily pain; for they thought that 
to suffer pain was hard, but that to be pleased was more in harmony with the nature of man, on which account also they took more care of the body than of the mind.

And although pleasure is desirable for its own sake, still they admit that some of the efficient causes of it are of ten troublesome, and as such opposite to pleasure; so that they think that an assemblage of all the pleasures which produce happiness is the most difficult thing conceivable. . . . They left out all investigation of the subjects of natural philosophy, because of the evident impossibility of comprehending them; but they applied themselves to the study of logic, because of its utility. ... They also taught that there was nothing naturally and intrinsically just, or honorable, or disgraceful; but that things were considered so because of law and fashion. The good man will do nothing out of the way, because of the punishments which are imposed on, and the discredit which is attached to, such actions: and that the good man is a wise man.

\section{THE CYNICS-ANTISTHENES AND DIOGENES}

Originally ${ }^{5}$ he [Antisthenes] was a pupil of Gorgias the rhetorician. ... Afterward, he attached himself to Socrates, and made such progress in philosophy while with him, that he advised all his own pupils to become his fellow-pupils in the school of Socrates. And as he lived in the Piræus he went up forty furlongs to the city every day in order to hear Socrates, from whom he learnt the art of enduring, and of being indifferent to

- From Diogenes Laertius, Yonge's translation, p. 217. 
external circumstances, and so became the original founder of the Cynic school.

And he used to argue that labor was a good thing, by adducing the examples of the great Hercules, and of Cyrus. ... . And he used continually to say, "I would rather go mad than feel pleasure."

And ${ }^{6}$ the doctrines he adopted were these: He used to insist that virtue was a thing which might be taught; also, that the nobly born and virtuously disposed were the same people; for that virtue was of itself sufficient for happiness, and was in need of nothing, except the strength of Socrates. He also looked upon virtue as a species of work, not wanting many arguments, or much instruction; and he taught that the wise man was sufficient for himself; for that everything that belonged to any one else belonged to him. He considered obscurity of fame a good thing, and equally good with labor. And he used to say that the wise man would regulate his conduct as a citizen, not according to the established laws of the state, but according to the law of virtue.

Diocles also attributes the following apophthegms to him: To the wise man, nothing is strange and nothing remote. The virtuous man is worthy to be loved. Good men are friends. It is right to make the brave and just one's allies. Virtue is a weapon of which a man cannot be deprived. It is better to fight with a few good men against all the wicked, than with many wicked men against a few good men. One should attend to one's enemies, for they are the first persons to detect one's errors. One should consider a just man as of more

- From Diogenes Laertius, Yonge's translation, pp. 220-221. 
value than a relation. Virtue is the same in a man as in a woman. What is good is honorable, and what is bad is disgraceful. Think everything that is wicked, foreign. Prudence is the safest fortification; for it can neither fall to pieces nor be betrayed. One must prepare one's self a fortress in one's own impregnable thoughts.

The 7 Cynics were for ${ }^{*^{*} *}$ doing away with the whole system of logic and natural philosophy . . . and held that one should devote one's self solely to the study of ethics. . . . They would discard all liberal studies. . . . Their doctrine is that the chief good of man consists in living according to virtue. . . . They also teach that men ought to lead the simple life, eating only plain food, and that in moderation, wearing nothing but a cloak, and showing contempt for wealth and fame and noble birth.

$$
*^{*}{ }^{*}
$$

Diogenes ${ }^{8}$ used to say that there are two kinds of training, that of the mind and that of the body ... and that neither is complete without the other. And he said that training gives power to overcome every obstacle, and that everywhere in life training is the condition of success. . . . He held that those who gave up useless labor and confined themselves to the tasks that nature enjoined, could not fail to live happily. It is our folly alone that makes us unhappy. For the very contempt of pleasure, when one has grown accustomed to it, is itself a source of great pleasure. And just as those who are accustomed to a life of luxury are brought very unwillingly to adopt the simple life, so those who have been trained in the latter take pleasure in their very scorn of pleasure.

'Diog. Laert. VI, 103.

Ib. VI. 70. 


\section{XII}

\section{PLATO}

[427-347 B.c.]

Plato's relation to his PREDeCessors, according to aristotle

AFTER $^{1}$ the philosophers we have described ${ }^{2}$ appeared the philosophical system of Plato which agreed with their views in many points, but had its own peculiar tenets which distinguished it from the philosophy of the Italic school. For from his youth up Plato had been familiar with Cratylus and with the opinions of the Heraclitean school-that all things of sense are in perpetual flux and that no real knowledge of them is possible. These views Plato held in later life as well. But while Socrates was occupying himself with ethical investigations, and not at all with nature as a whole, and yet in these investigations was in search of the general law and was the first to direct his attention to the task of definition,-Plato accepted this view too, but drew the conclusion that the definition had for its object something distinct from the objects of sense, for it was impossible that there should be a common definition of any one of the objects of sense, since these are continually changing. And such realities he called ideas; but he held that the objects of sense existed over and above ideas and were all named after them; for the many things that are called by the same name with the ideas exist only through "participation" in them. This ex-

Arist. Met. I. 6, 98\% a 29.

2 I. e., the Pythagoreans 
pression "participation" is but a new name for an older view, for the Pythagoreans declared that things that are exist through "imitation" of numbers; Plato, changing the name, says it is through participation. But exactly what is the nature of this participation or of this imitation they have alike failed to explain. Furthermore Plato holds that over and above the objects of sense and the ideas exist the objects with which mathematics deals, occupying an intermediate position, differing from the objects of sense in being eternal and immovable, and differing on the other hand from the ideas in that there are many fac-similes of each, whereas every selfexistent idea is one and one only.

\section{From the Phadrus}

DIALECTIC VERSUS RHETORIC

Socrates.-But let me ask you, friend: have we not reached the plane-tree to which you were conducting us?

Phodrus.-Yes, this is the tree.

Soc.-By Herè, a fair resting-place, full of summer sounds and scents. Here is this lofty and spreading plane-tree, and the agnus castus high and clustering, in the fullest blossom and the greatest fragrance; and the stream which flows beneath the plane-tree is deliciously cold to the feet. Judging from the ornaments and images, this must be a spot sacred to Achelous and the Nymphs. How delightful is the breeze:-so very sweet; and there is a sound in the air shrill and summerlike which makes answer to the chorus of the cicadx. But the greatest charm of all is the grass, like a pillow gently sloping to the head. My dear Phædrus, you have been an admirable guide.

'From Plato's Phødrus, Jowett's translation, beginning p. 230 A. 
Phoedr. - What an incomprehensible being you are, Socrates: when you are in the country, as you say, you really are like some stranger who is led about by a guide. Do you ever cross the border? I rather think that you never venture even outside the gates.

Soc.-Very true, my good friend; and I hope that you will excuse me when you hear the reason, which is, that I am a lover of knowledge, and the men who dwell in the city are my teachers, and not the trees or the country. Though I do indeed believe that you have found a spell with which to draw me out of the city into the country, like a hungry cow before whom a bough or bunch of fruit is waved. For only hold up before me in like manner a book, and you may lead me all round Attica, and over the wide world. And now having arrived, I intend to lie down, and do you choose any posture in which you can read best.

[Referring to the love-myth which he had unfolded in the Phædrus Socrates comments as follows:] 4

The composition was mostly playful. Yet in these chance fancies of the hour were involved two principles of which we should be too glad to have a clearer description if art could give us one.

Phodr. - What are they?

Soc.-First, the comprehension of scattered particulars in one idea; as in our definition of love, which whether true or false certainly gave clearness and consistency to the discourse, the speaker should define his several notions and so make his meaning clear.

Phocdr.-What is the other principle, Socrates?

‘ From Plato's Phadrus, Jowett's translation, beginning p. 265 D. 
Soc.-The second principle is that of division into species according to the natural formation, where the joint is, not breaking any part as a bad carver might. Just as our two discourses, alike assumed, first of all, a single form of unreason; and then, as the body which from being one becomes double and may be divided into a left side and right side, each having parts right and left of the same name-after this manner the speaker proceeded to divide the parts of the left side and did not desist until he found in them an evil or left-handed love which he justly reviled; and the other discourse leading us to the madness which lay on the right side, found another love, also having the same name, but divine, which the speaker held up before us and applauded and affirmed to be the author of the greatest benefits.

Phodr.-Most true.

Soc.-I am myself a great lover of these processes of division and generalization; they help me to speak and to think. And if I find any man who is able to see "a One and Many" in nature, him I follow, and "walk in his footsteps as if he were a goll." And those who have this art, I have hitherto been in the habit of calling dialecticians; but God knows whether the name is right or not. . . .

Oratory ${ }^{5}$ is the art of enchanting the soul, and therefore he who would be an orator has to learn the differences of human souls-they are so many and of such a nature, and from them come the differences between man and man. Having proceeded thus far in his analysis, he will next divide speeches into their different classes: "Such and such persons," he will say, "are

- From Plato's Phødrus, Jowett's translation, beginning p. 271 D. 
affected by this or that kind of speech in this or that way," and he will tell you why. The pupil must have a good theoretical notion of them first, and then he must have experience of them in actual life, and be able to follow them with all his senses about him, or he will never get beyond the precepts of his masters. But when he understands what persons are persuaded by what arguments, and sees the person about whom he was speaking in the abstract actually before him, and knows that it is he, and can say to himself, "This is the man or this is the character who ought to have a certain argument applied to him in order to convince him of a certain opinion"; he who knows all this, and knows also when he should speak and when he should refrain, and when he should use pithy sayings, pathetic appeals, sensational effects, and all the other modes of speech which he has learned; when, I say, he knows the times and seasons of all these things, then, and not till then, he is a perfect master of his art; but if he fail in any of these points, whether in speaking or teaching or writing them, and yet declares that he speaks by rules of art, he who says, "I don't believe you," has the better of him.

\section{From the Symposium}

ON LOVE

I will rehearse a tale of love which I heard from Diotima of Mantineia, a woman wise in this and in many other kinds of knowledge, who in the days of old, when the Athenians offered sacrifice before the coming of the plague, delayed the disease ten years. She was my instructress in the art of love, and I shall repeat to you

- From Plato's Symposium, Jowett's translation, beginning p. $201 \mathrm{D}$. 
what she said to me. . . "What then is Love?" I asked. "Is he mortal?" "No." "What then?" "As in the former instance, he is neither mortal nor immortal, but in a mean between the two." "What is he, Diotima?" "He is a great spirit ( $\delta a(\mu \omega \nu)$, and like all spirits he is intermediate between the divine and the mortal." "And what," I said, "is his power?" "He interprets," she replied, "between gods and men, conveying and taking across to the gods the prayers and sacrifices of men, and to men the commands and replies of the gods; he is the mediator who spans the chasm which divides them, and therefore in him all is bound together, and through him the arts of the prophet and the priest, their sacrifices and mysteries and charms, and all prophecy and incantation, find their way. For God mingles not with man; but through Love all the intercourse and converse of God with man, whether awake or asleep, is carried on. The wisdom which understands this is spiritual; all other wisdom, such as that of arts and handicrafts, is mean and vulgar. Now these spirits or intermediate powers are many and diverse, and one of them is Love. . . .

"You may say generally that all desire of good and happiness is only the great and subtle power of love; but they who are drawn toward him by any other path, whether the path of money-making or gymnastics or philosophy, are not called lovers-the name of the whole is appropriated to those whose affection takes one form only-they alone are said to love, or to be lovers." "I dare say," I replied, "that you are right." "Yes," she added, "and you hear people say that lovers are seeking for their other half; but I say that they are reeking neither for the half of themselves nor for the 
whole, unless the half or the whole be also a good. And they will cut off their own hands and feet and cast them away, if they are evil; for they love not what is their own, unless perchance there be some one who calls what belongs to him the good, and what belongs to another the evil. For there is nothing which men love but the good. Is there anything?" "Certainly, I should say, that there is nothing." "Then," she said, "the simple truth is, that men love the good." "Yes," I said. "To which must be added that they love the possession of the good?" "Yes, that must be addled." "And not only the possession, but the everlasting possession of the good?" "That must be added too." "Then love," she said, "may be described generally as the love of the everlasting possession of the good?" "That is most true."

"Then if this be the nature of love, can you tell me further," she said, "what is the manner of the pursuit? what are they doing who show all this eagerness and heat which is called love? and what is the object which they have in view? Answer me." "Nay, Diotima," I replied, "if I had known, I should not have wondered at your wisdom, neither should I have come to learn from you about this very matter." "Well," she said, "I will teach you: The object which they have in view is birth in beauty whether of body or soul. . . . . .

"These are the lesser mysteries of love, into which even you, Socrates, may enter; to the greater and more hidden ones which are the crown of these, and to which, if you pursue them in a right spirit, they will lead, I know not whether you will be able to attain. But I will do my utmost to inform you, and do you follow if you can. For he who would proceed aright in this matter 
should begin in youth to visit beautifu forms; and first, if he be guided by his instructor aright, to love one such form only-out of that he should create fair thoughts; and soon he will of himself perceive that the beauty of one form is akin to the beauty of another; and then if beauty of form in general is his pursuit, how foolish would he be not to recognize that the beauty in every form is one and the same! And when he perceives this he will abate his violent love of the one, which he will despise and deem a small thing, and will become a lover of all beautiful forms; in the next stage he will consider that the beauty of the mind is more honorable than the beauty of the outward form. So that if a virtuous soul have but a little comeliness, he will be content to love and tend him, and will search out and bring to the birth thoughts which may improve the young, until he is compelled to contemplate and see the beauty of institutions and laws, and to understand that the beauty of them all is of one family, and that personal beauty is a trifle; and after laws and institutions he will go on to the sciences, that he may see their beauty, being not like a servant in love with the beauty of one youth or man or institution, himself a slave mean and narrow-minded, but drawing toward and contemplating the vast sea of beauty, he will create many fair and noble thoughts and notions in boundless love of wisdom; until on that shore he grows and waxes strong, and at last the vision is revealed to him of a single science, which is the science of beauty everywhere. To this I will proceed; please to give me your very best attention:

"He who has been instructed thus far in the things of love, and who has learned to see the beautiful in due order and succession, when he comes toward the end will 
suddenly perceive a nature of wondrous beauty (and this, Socrates, is the final cause of all our former toils)a nature which in the first place is everlasting, not growing and decaying, or waxing and waning; secondly, not fair in one point of view and foul in another, or at one time or in one relation or at one place fair, at another time or in another relation or at another place foul, as if fair to some and foul to others, or in the likeness of a face or hands or any other part of the bodily frame, or in any form of speech or knowledge, or existing in any other being, as for example, in an animal, or in heaven, or in earth, or in any other place; but beauty absolute, separate, simple, and everlasting, which without diminution and without increase, or any change, is imparted to the ever-growing and perishing beauties of all other things. He who from these ascending under the influence of true love, begins to perceive that beauty, is not far from the end. And the true order of going, or being led by another, to the things of love, is to begin from the beauties of earth and mount-upward for the sake of that other beauty, using these as steps only, and from one going on to two, and from two to all fair forms, and from fair forms to fair practices, and from fair practices to fair notions, until from fair notions he arrives at the notion of absolute beauty, and at last knows what the essence of beauty is. This, my dear Socrates," said the stranger of Mantineia, "is that life above all others which man should live, in the contemplation of beauty absolute; a beauty which if you once beheld, you would see not to be after the measure of gold, and garments, and fair boys and youths, whose presence now entrances you; and you and many a one would be content to live seeing them only and conversing with them without 
meat or drink, if that were possible-you only want to look at them and to be with them. But what if man had eyes to see the true beauty-the divine beauty, I mean, pure and clear and unalloyed, not clogged with the pollutions of mortality and all the colors and vanities of human life-thither looking, and holding converse with the true beauty simple and divine? Remember how in that communion only, beholding beauty with the eye of the mind, he will be enabled to bring forth, not images of beauty, but realities (for he has hold not of an image, but of a reality), and bringing forth and nourishing true virtue to become the friend of God and be immortal, if mortal man may. Would that be an ignoble life?"

Such, Phædrus-and I speak not only to you, but to all of you-were the words of Diotima; and I am persuaded of their truth. And being persuaded of them, I try to persuade others, that in the attainment of this end human nature will not easily find a helper better than love. And therefore, also, I say that every man ought to honor him as I myself honor him, and walk in his ways, and exhort others to do the same, and praise the power and spirit of love according to the measure of my ability now and ever.

\section{From the Philebus'}

\section{PLEASURE AND THE OTHER GOODS}

Socrates. - Then, Protarchus, you will proclaim everywhere, by word of mouth to this company, and by messengers bearing the tidings far and wide, that pleasure is not the first of possessions, nor yet the second, but that in measure, and the mean, and the suitable, and the like, the eternal nature has been found.

'From the Philebus, p. 66 A, Jowett's translation. 
Protarchus.-Yes, that seems to be the result of what has been now said.

Soc.-In the second class is contained the symmetrical and beautiful and perfect or sufficient, and all which are of that family.

Pro.-True.

Soc.-And if you reckon in the third class mind and wisdom, you will not be far wrong, if I divine aright.

Pro.-I dare say.

Soc.-And would you not put in the fourth class the goods which we were affirming to appertain specially to the soul-sciences and arts and true opinions as we called them? These come after the third class, and form the fourth, as they are certainly more akin to good than pleasure is.

\section{Pro.-Surely.}

Soc.-The fifth class are the pleasures which were defined by us as painless, being the pure pleasures of the soul herself, as we termed them, which accompany, some the sciences, and some the senses.

Pro.-Perhaps.

Soc.-And now, as Orpheus says:

With the sixth generation cease the glory of my song.

Here, at the sixth award, let us make an end; all that remains is to set the crown on our discourse.

Pro.-True.

Soc.-Then let us sum up and reassert what has been said, thus offering the third libation to the saviour Zeus.

Pro.-How?

Soc.-Philebus affirmed that pleasure was always and absolutely the good. 
Pro.-I understand; this third libation, Socrates, of which you spoke, meant a recapitulation.

Soc.-Yes, but listen to the sequel; convinced of what I have just been saying, and feeling indignant at the doctrine, which is maintained, not by Philebus only, but by thousands of others, I affirmed that mind was far better and far more excellent, as an element of human life, than pleasure.

Pro.-True.

Soc.-But, suspecting that there were other things which were also better, I went on to say that if there was anything better than either, then I would claim the second place for mind over pleasure, and pleasure would lose the second place as well as the first.

Pro.-You did.

Soc.-Nothing could be more satisfactorily shown than the unsatisfactory nature of both of them.

Pro.-Very true.

Soc.-The claims both of pleasure and mind to be the absolute good have been entirely disproven in this argument, because they are both wanting in selfsufficiency and also in adequacy and perfection.

Pro.-Most true.

Soc.-But, though they must both resign in favor of another, mind is ten thousand times nearer and more akin to the nature of the conqueror than pleasure.

Pro.-Certainly.

Soc.-And, according to the judgment which has now been given, pleasure will rank fifth.

Pro.-True.

Soc.-But not first; no, not even if all the oxen and horses and animals in the world by their pursuit of enjoyment proclaim her to be so;-although the many 
trusting in them, as diviners trust in birds, determine that pleasures make up the good of life, and deem the lusts of animals to be better witnesses than the inspirations of divine philosophy.

\section{From the Timaeus:}

\section{THE CREATION OF THE WORLD}

Timceus.-All men, Socrates, who have any degree of right feeling, at the beginning of every enterprise, whether small or great, always call upon God. And we, too, who are going to discourse of the nature of the universe, how created or how existing without creation, if we be not altogether out of our wits, must evoke the aid of gods and goddesses and pray that our words may be acceptable to them and consistent with themselves. Let this, then, be our invocation of the gods, to which I add an exhortation of myself to speak in such manner as will be most intelligible to you, and will most accord with my own intent.

First then, in my judgment, we must make a distinction and ask, What is that which always is and has no becoming; and what is that which is always becoming and never is? That which is apprehended by intelligence and reason is always in the same state; but that which is conceived by opinion with the help of sensation and without reason, is always in a process of becoming and perishing and never really is. Now everything that becomes or is created must of necessity be created by some cause, for without a cause nothing can be created. The work of the creator, whenever he looks to the unchangeable and fashions the form and nature of his work after an unchangeable pattern, must necessarily be made

- From the Timaus, beginning page $27 \mathrm{C}$, Jo wett's translation. 
fair and perfect; but when he looks to the created only, and uses a created pattern, it is not fair or perfect. Was the heaven then or the world, whether called by this or by any other more appropriate name-assuming the name, I am asking a question which has to be asked at the beginning of an inquiry about anything-was the world, I say, always in existence and without beginning? or created, and had it a beginning? Created, I reply, being visible and tangible and having a body, and therefore sensible; and all sensible things aresapprehended by opinion and sense and are in a process of creation and created. Now that which is created must, as we affirm, of necessity be created by a cause. But the father and maker of all this universe is past finding out; and even if we found him, to tell of him to all men would be impossible. And there is still a question to be asked about him: Which of the patterns had the artificer in view when he made the world,- the pattern of the unchangeable, or of that which is created? If the world be indeed fair and the artificer good, it is manifest that he must have looked to that which is eternal; but if what cannot be said without blasphemy is true, then to the created pattern. Every one will see that he must have looked to the eternal; for the world is the fairest of creations and he is the best of causes. And having been created in this way, the world has been framed in the likeness of that which is apprehended by reason and mind and is unchangeable, and must therefore of necessity, if this is admitted, be a copy of something. Now it is allimportant that the beginning of everything should be according to nature. And in speaking of the copy and the original we may assume that words are akin to the matter which they describe; when they relate to the 
lasting and permanent and intelligible, they ought to be lasting and unalterable, and, as far as their nature allows, irrefutable and immovable-nothing less. But when they express only the copy or likeness and not the eternal things themselves, they need only be likely and analogous to the real words. As being is to becoming, so is truth to belief. If then, Socrates, amid the many opinions about the gods and the generation of the universe, we are not able to give notions which are altogether and in every respect exact and consistent with one another, do not be surprised. Enough, if we adduce probabilities as likely as any others; for we must remember that I who am the speaker, and you who are the judges, are only mortal men, and we ought to accept the tale which is probable and inquire no further.

Soc.-Excellent, Timæus; and we will do precisely as you bid us. The prelude is charming, and is already accepted by us-may we beg of you to proceed to the strain?

Tim.-Let me tell you then why the Creator made this world of generation. He was good, and the good can never have any jealousy of anything. And being free from jealousy, he desired that all things should be as like himself as they could be. This is in the truest sense the origin of creation and of the world, as we shall do well in believing on the testimony of wise men: God desired that all things should be good and nothing bad, so far as this was attainable. Wherefore also finding the whole visible sphere not at rest, but moving in an irregular and disorderly fashion, out of disorder he brought order, considering that this was in every way better than the other. Now the deeds of the best could never be or have been other than the fairest; and the Creator, reflecting 
on the things which are by nature visible, found that no unintelligent creature taken as a whole was fairer than the intelligent taken as a whole; and that intelligence could not be present in anything which was devoid of soul. For which reason, when he was framing the universe, he put intelligence in soul, and soul in body, that he might be the creator of a work which was by nature fairest and best. Wherefore, using the language of probability, we may say that the world became a living creature truly endowed with soul and intelligence by the providence of God.

This being supposed, let us proceed to the nexı stage: In the likeness of what animal did the Creator make the world? It would be an unworthy thing to liken it to any nature which exists as a part only; for nothing can be beautiful which is like any imperfect thing; but let us suppose the world to be the very image of that whole of which all other animals both individually and in their tribes are portions. For the original of the universe contains in itself all intelligible beings, just as this world comprehends us and all other visible creatures. For the Deity, intending to make this world like the fairest and most perfect of intelligible beings, framed one visible animal comprehending within itself all other animals of a kindred nature. Are we right in saying that there is one world, or that they are many and infinite? There must be one only, if the created copy is to accord with the original. For that which includes all other intelligible creatures cannot have a second or companion; in that case there would be need of another living being which would include both, and of which they would be parts, and the likeness would be more truly said to resemble not them, but that other which included them. 


\section{SOURCE BOOK IN ANCIENT PHILOSOPHY}

In order then that the world might be solitary, like the perfect animal, the Creator made not two worlds or an infinite number of them; but there is and ever will be one only-begotten and created heaven.

Such was the whole plan of the eternal God about the god that was to be, to whom for this reason he gave a body, smooth and even, having a surface in every direction equidistant from the centre, a body entire and perfect, and formed out of perfect bodies. And in the centre he put the soul, which he diffused throughout the body, making it also to be the exterior environment of it; and he made the universe a circle moving in a circle, one and solitary, yet by reason of its excellence, able to converse with itself, and needing no other friendship or acquaintance. Having these purposes in view he created the world a blessed god.

Now God did not make the soul after the body, although we are speaking of them in this order; for having brought them together he would never have allowed that the elder should be ruled by the younger; but this is a random manner of speaking which we have, because somehow we ourselves too are very much under the dominion of chance. Whereas he made the soul in origin and excellence prior to and older than the body, to be the ruler and mistress, of whom the body was to be the subject. And he made her out of the following elements and on this wise: Out of the indivisible and unchangeable, and also out of that which is divisible and has to do with material bodies, he compounded a third and intermediate kind of essence, partaking of the nature of the same and of the other, and this compound he placed accordingly in a mean between the indivisible and the divisible and material. He took the three elements of 
the same, the other and the essence, and mingled them into one form, compressing by force the reluctant and unsociable nature of the other into the same. When he had mingled them with the essence and out of the three made one, he again divided this whole into as many portions as was fitting, each portion being a compound of the same, the other, and the essence.

Now when the Creator had framed the soul according to his will, he formed within her the corporeal universe, and brought the two together, and united them centre to centre. The soul, infused everywhere from the centre to the circumference of heaven, of which also she is the external envelopment, herself turning in herself, began a divine beginning of never-ceasing and rational life enduring throughout all time. The body of heaven is visible, but the soul is invisible, and partakes of reason and harmony, and being made by the best of intellectual and everlasting natures, is the best of things created.

When the Father and Creator saw the creature which he had made moving and living, the created image of the eternal gods, he rejoiced, and in his joy determined to make the copy still more like the original; and as this was eternal, he sought to make the universe eternal, so far as might be. Now the nature of the ideal being was everlasting, but to bestow this attribute in its fulness upon a creature was impossible. Wherefore he resolved to have a moving image of eternity, and when he set in order the heaven, he made this image eternal but moving according to number, while eternity itself rests in unity; and this image we call time. For there were no days and nights and months and years before the heaven was created, but when he constructed the heaven he created them also. They are all parts of 
time, and the past and future are created species of time, which we unconsciously but wrongly transfer to the eternal essence; for we say that he "was," he "is," he "will be," but the truth is that "is" alone is properly attributed to him, and that "was" and "will be" are only to be spoken of becoming in time, for they are motions, but that which is immovably the same cannot become older or younger by time, nor ever did or has become, or hereafter will be, older or younger, nor is subject at all to any of those states which affect moving and sensible things and of which generation is the cause. These are the forms of time, which imitates eternity and revolves according to a law of number. Moreover, when we say that what has become is become and what becomes is becoming, and that what will become $i$ s about to become and that the non-existent is non-existent-all these are inaccurate modes of expression. But perhaps this whole subject will be more suitably discussed on some other occasion. . . . .

This new beginning of our discussion of the universe requires a fuller division than the former; for then we made two classes, now a third must be revealed. The two sufficed for the former discussion; one, which we assumed, was a pattern intelligible and always the same; and the second was only the imitation of the pattern, generated and visible. There is also a third kind which we did not distinguish at the time, conceiving that the two would be enough. But now the argument seems to require that we should set forth in words another kind, which is difficult of explanation and dimly seen. What nature are we to attribute to this new kind of being? We reply, that it is the receptacle, and in a manner the nurse, of all generation. . . . 
WHY IT IS NECESSARY TO ASSUME EXISTENCE OF THE IDEAS

Do all those things which we call self-existent exist? or are only those things which we see, or in some way perceive through the bodily organs, truly existent, and nothing whatever besides them? And is all that which we call an intelligible essence nothing at all, and only a name? Here is a question which we must not leave unexamined or undetermined, nor must we affirm too confidently that there can be no decision; neither must we interpolate in our present long discourse a digression equally long, but if it is possible to set forth a great principle in a few words, that is just what we want.

Thus I state my view: If mind and true opinion are two distinct classes, then I say that there certainly are these self-existent ideas unperceived by sense, and apprehended only by the mind; if, however, as some say, true opinion differs in no respect from mind, then everything that we perceive through the body is to be regarded as most real and certain. But we must affirm them to be distinct, for they have a distinct origin and are of a different nature; the one is implanted in us by instruction, the other by persuasion; the one is always accompanied by true reason, the other is without reason; the one cannot be overcome by persuasion, but the other can; and lastly, every man may be said to share in true opinion, but mind is the attribute of the gods and of very few men. Wherefore also we must acknowledge that there is one kind of being which is always the same, uncreated and indestructible, never receiving anything into itself from without, nor itself going out to any other, but invisible and imperceptible by any sense, and of which the eontemplation is granted to intelligence only. And there is another nature of the same name with it, 
and like to it, perceived by sense, created, always in motion, becoming in place and again vanishing out of place, which is apprehended by opinion and sense. And there is a third nature, which is space, and is eternal, and admits not of destruction and provides a home for all created things, and is apprehended without the help of sense, by a kind of spurious reason, and is hardly real; which we beholding as in a dream, say of all existence that it must of necessity be in some place and occupy a space, but that what is neither in heaven nor in earth has no existence. Of these and other things of the same kind, relating to the true and waking reality of nature, we have only this dream-like sense, and we are unable to cast off sleep and determine the truth about them. For an image, since the reality, after which it is modelled, does not belong to it, and it exists ever as the fleeting shadow of some other, must be inferred to be in another [i. e., in space], grasping existence in some way or other, or it could not be at all. But true and exact reason, vindicating the nature of true being, maintains that while two things [i.e., the image and space] are different they cannot exist one of them in the other and so be one and also two at the same time.

\section{From the Parmenides ${ }^{\circ}$}

PUZZLES PRESENTED BY THE THEORY OF IDEAS

"I understand," said Socrates, "and quite accept your account. But tell me, Zeno, do you not further think that there is an idea of likeness in itself, and another idea of unlikeness, which is the opposite of likeness, and that in these two you and I, and all other things to which we apply the term many, participate-things which

- From the Parmenides, Jowett's translation, beginning p. $128 \mathrm{E}$. 
participate in likeness become in that degree and manner like; and so far as they participate in unlikeness become in that degree unlike, or both like and unlike in the degree in which they participate in both? And may not all things partake of both opposites, and be both like and unlike, by reason of this participation? Where is the wonder? Now if a person could prove the absolute like to become unlike, or the absolute unlike to become like, that, in my opinion, would indeed be a wonder; but there is nothing extraordinary, Zeno, in showing that the things which only partake of likeness and unlikeness experience both. Nor, again, if a person were to show that all is one by partaking of one, and at the same time many by partaking of many, would that be very astonishing? But if he were to show me that the absolute one was many, or the absolute many one, I should be truly amazed. And so of all the rest: I should be surprised to hear that the natures or ideas themselves had these opposite qualities; but not if a person wanted to prove of me that I was many and also one. When he wanted to show that I was many he would say that I have a right and a left side, and a front and a back, and an upper and a lower half, for I cannot deny that I partake of multitude; when, on the other hand, he wants to prove that I am one, he will say, that we who are here assembled are seven, and that I am one, and partake of the one. In both instances he proves his case. So again, if a person shows that such things as wood, stones, and the like, being many are also one, we admit that he shows the coexistence of the one and many, but he does not show that the many are one or the one many; he is utteringr not a paradox but a truism. If, however, as I just now suggested, some one were to abstract simple notions of 
like, unlike, one, many, rest, motion, and similar ideas, and then to show that these admit of admixture and separation in themselves, I should be very much astonished. This part of the argument appears to be treated by you, Zeno, in a very spirited manner; but, as I was saying, I should be far more amazed if any one found in the ideas themselves which are apprehended by reason, the same puzzle and entanglement which you have shown to exist in visible objects."

While Socrates was speaking, Pythodorus thought that Parmenides and Zeno were not altogether pleased at the successive steps of the argument; but still they gave the closest attention, and of ten looked at one another, and smiled as if in admiration of him. When he had finished, Parmenides expressed their feelings in the following words:

"Socrates," he said, "I admire the bent of your mind toward philosophy; tell me now, was this your own distinction between ideas in themselves and the things which partake of them? and do you think that there is an idea of likeness apart from the likeness which we possess, and of the one and many, and of the other things which Zeno mentioned?"

"I think that there are such ideas," said Socrates.

Parmenides proceeded: "And would you also make absolute ideas of the just and the beautiful and the good, and of all that class?"

"Yes," he said, "I should."

"And would you make an idea of man apart from us and from all other human creatures, or of fire and water?"

"I am of ten undecided, Parmenides, as to whether I ought to include them or not."

"And would you feel equally undecided, Socrates, 
about things of which the mention may provoke a smile? -I mean such things as hair, mud, dirt, or anything else which is vile and paltry; would you suppose that each of these has an idea distinct from the actual objects with which we come into contact, or not?"

"Certainly not," said Socrates; "visible things like these are such as they appear to us, and I am afraid that there would be an absurdity in assuming any idea of them, although I sometimes get disturbed, and begin to think that there is nothing without an idea; but then again, when I have taken up this position, I run away, because I am afraid that I may fall into a bottomless pit of nonsense, and perish; and so I return to the ideas of which I was just now speaking, and occupy myself with them."

"Yes, Socrates," said Parmenides; "that is because you are still young; the time will come, if I am not mistaken, when philosophy will have a firmer grasp of you, and then you will not despise even the meanest things; at your age, you are too much disposed to regard the opinions of men. But I should like to know whether you mean that there are certain illeas of which all other things partake, and from which they derive their names; that similars, for example, become similar, because they partake of similarity; and great things become great, because they partake of greatness; and that just and beautiful things become just and beautiful because they partake of justice and beauty?"

"Yes, certainly," said Socrates, "that is my meaning."

"Then each individual partakes either of the whole of the idea or else of a part of the idea? Can there be any other mode of participation?"

"There cannot be," he said. 
"Then do you think that the whole idea is one, and yet, being one, is in each one of the many?"

"Why not, Parmenides?" said Socrates.

"Because one and the same thing will exist as a whole at the same time in many separate individuals, and will therefore be in a state of separation from itself."

"Nay, but the idea may be like the day which is one and the same in many places at once, and yet continuous with itself ; in this way each idea may be one and the same in all at the same time."

"I like your way, Socrates, of making one in many places at once. You mean to say, that if I were to spread out a sail and cover a number of men, there would be one whole including many-is not that your meaning?"

"I think so."

"And would you say that the whole sail includes each man, or part of it only, and different parts different men?"

"The latter."

"Then, Socrates, the ideas themselves will be divisible, and things which participate in them will have a part of them only and not the whole idea existing in each of them?"

"That seems to follow."

"Then would you like to say, Socrates, that the one idea is really divisible and yet remains one?"

"Certainly not," he said.

"Suppose that you divide absolute greatness, and that of the many great things, each one is great in virtue of a portion of greatness less than absolute greatness-is that conceivable?"

"No." 
"Or will each equal thing, if possessing some small portion of equality less than absolute equality, be equal to some other thing by virtue of that portion only?"

"Impossible."

"Or suppose one of us to have a portion of smallness; this is but a part of the small, and therefore the absolutely small is greater; if the absolutely small be greater, that to which the part of the small is added will be smaller and not greater than before."

"How absurd!"

"Then in what way, Socrates, will all things participate in the ideas, if they are unable to participate in them either as parts or wholes?"

"Indeed," he said, "you have asked a question which is not easily answered."

"Well," said Parmenides, "and what do you say of another question?"

"What question?"

"I imagine that the way in which you are led to assume one idea of each kind is as follows: You see a number of great objects, and when you look at them there seems to you to be one and the same idea (or nature) in them all; hence you conceive of greatness as one."

"Very true," said Socrates.

"And if you go on and allow your mind in like manner to embrace in one view the idea of greatness and of great things which are not the idea, and to compare them, will not another greatness arise, which will appear to be the source of all these?"

"It would seem so."

"Then another idea of greatness now comes into view over and above absolute greatness, and the individuals 
which partake of it; and then another, over and above all these, by virtue of which they will all be great, and so each idea instead of being one will be infinitely multiplied."

"But may not the ideas," asked Socrates, "be thoughts only, and have no proper existence except in our minds, Parmenides? For in that case each idea may still be one, and not experience this infinite multiplication."

"And can there be individual thoughts which are thoughts of nothing?"

"Impossible," he said.

"The thought must be of something?"

"Yes."

"Of something which is or which is not?"

"Of something which is."

"Must it not be of a single something, which the thought recognizes as attaching to all, being a single form or nature?"

"Yes."

"And will not the something which is apprehended as one and the same in all, be an idea?"

"From that, again, there is no escape."

"Then," said Parmenides, "if you say that everything else participates in the ideas, must you not say either that everything is made up of thoughts, and that all things think; or that they are thoughts but have no thought?"

"The latter view, Parmenides, is no more rational than the previous one. In my opinion, the ideas are, as it were, patterns fixed in nature, and other things are like them, and resemblances of them-what is meant by the participation of other things in the ideas, is really assimilation to them." 
"But if," said he, "the individual is like the idea, must not the idea also be like the individual, in so far as the individual is a resemblance of the idea? That which is like, cannot be conceived of as other than the like of like."

"Impossible."

"And when two things are alike, must they not partake of the same idea?"

"They must."

"And will not that of which the two partake, and which makes them alike, be the idea itself ?"

"Certainly."

"Then the idea cannot be like the individual, or the individual like the idea; for if they are alike, some further idea of likeness will always be coming to light, and if that be like anything else, another; and new ideas will be always arising, if the idea resembles that which partakes of it?"

"Quite true."

"The theory, then, that other things participate in the ideas by resemblance, has to be given up, and some other mode of participation devised?"

"It would seem so."

"Do you see then, Socrates, how great is the difficulty of affirming the ideas to be absolute?"

"Yes, indeed."

"And, further, let me say that as yet you only understand a small part of the difficulty which is involved if you make of each thing a single idea, parting it off from other things."

"What difficulty?" he said.

"There are many, but the greatest of all is this: If an opponent argues that these ideas, being such as we say they ought to be, must remain unknown, no one can 
prove to him that he is wrong, unless he who denies their existence be a man of great ability and knowledge, and is willing to follow a long and laborious demonstration; he will remain unconvinced, and still insist that they cannot be known."

"What do you mean, Parmenides?" said Socrates.

"In the first place, I think, Socrates, that you, or any one who maintains the existence of absolute essences, will admit that they cannot exist in us."

"No," said Socrates; "for then they would be no longer absolute."

"True," he said; "and therefore when ideas are what they are in relation to one another, their essence is determined by a relation among themselves, and has nothing to do with the resemblances, or whatever they are to be termed, which are in our sphere and from which we receive this or that name when we partake of them. And the things which are within our sphere and have the same names with them, are likewise only relative to one another, and not to the ideas which have the same names with them, but belong to themselves and not to them."

"What do you mean?" said Socrates.

"I may illustrate my meaning in this way," said Parmenides: "A master has a slave; now there is nothing absolute in the relation between them, which is simply a relation of one man to another. But there is also an idea of mastership in the abstract, which is relative to the idea of slavery in the abstract. These natures have nothing to do with us, nor we with them; they are concerned with themselves only, and we with ourselves. Do you see my meaning?"

"Yes," said Socrates, "I quite see your meaning." 
"And will not knowledge-I mean absolute knowledge -answer to absolute truth?"

"Certainly."

"And each kind of absolute knowledge will answer to each kind of absolute being?"

"Yes."

"But the knowledge which we have, will answer to the truth which we have; and again, each kind of knowledge which we have, will be a knowledge of each kind of being which we have?"

"Certainly."

"But the ideas themselves, as you admit, we have not, and cannot have?"

"No, we cannot."

"And the absolute natures or kinds are known severally by the absolute idea of knowledge?"

"Yes."

"And we have not got the idea of knowledge?"

"No."

"Then none of the ideas are known to us, because we have no share in absolute knowledge?"

"I suppose not."

"Then the nature of the beautiful in itself, and of the good in itself, and all other ideas which we suppose to exist absolutely, are unknown to us?"

"It would seem so."

"I think that there is a stranger consequence still."

"What is it?"

"Would you, or would you not say, that absolute knowledge, if there is such a thing, must be a far more exact knowledge than our knowledge; and the same of beauty and of the rest?"

"Yes." 
"And if there be such a thing as participation in absolute knowledge, no one is more likely than God to have this most exact knowledge?"

"Certainly."

"But then, will God, having absolute knowledge, have a knowledge of human things?"

"Why not?"

"Because, Socrates," said Parmenides, "we have admitted that the ideas are not valid in relation to human things; nor human things in relation to them; the relations of either are limited to their respective spheres."

"Yes, that has been admitted."

"And if God has this perfect authority, and perfect knowledge, His authority cannot rule us, nor $\mathrm{His}$ knowledge know us, or any human thing; just as our authority does not extend to the gods, nor our knowledge know anything which is divine, so by parity of reason they, being gods, are not our masters, neither do they know the things of men."

"Yet, surely," said Socrates, "to deprive God of knowledge is monstrous."

"These, Socrates," said Parmenides, "are a few, and only a few of the difficulties in which we are involved if ideas really are and we determine each one of them to be an absolute unity. He who hears what may be said against them will deny the very existence of them-and even if they do exist, he will say that they must of necessity be unknown to man; and he will seem to have reason on his side, and as we were remarking just now, will be very difficult to convince; a man must be gifted with very considerable ability before he can learn that everything has a class and an absolute essence; and still more remarkable will he be who discovers all these things 
for himself, and having thoroughly investigated them is able to teach them to others."

"I agree with you, Parmenides," said Socrates; "and what you say is very much to my mind."

"And yet, Socrates," said Parmenides, "if a man, fixing his attention on these and the like difficulties, does away with ideas of things and will not admit that every individual thing has its own determinate idea which is always one and the same, he will have nothing on which his mind can rest; and so he will utterly destroy the power of reasoning, as you seem to me to have particularly noted."

"Very true," he said.

"But then, what is to become of philosophy? Whither shall we turn, if the ideas are unknown?"

"I certainly do not see my way at present."

"Yes," said Parmenides; "and I think that this arises, Socrates, out of your attempting to define the beautiful, the just, the good, and the ideas generally, without sufficient previous training." 


\section{XIII}

\section{PLATO-(Continued)}

\section{From The Republic}

THE NATURE OF VIRTUE

"Tell ${ }^{1}$ me, do you think there is such a thing as a horse's function?"

"I do."

"Would you, then, describe the function of a horse, or of anything else whatever, as that work, for the accomplishment of which it is either the sole or the best instrument?"

"I do not understand."

"Look at it this way. Can you see with anything besides eyes?"

"Certainly not."

"Can you hear with anything besides ears?"

"No."

"Then should we not justly say that seeing and hearing are the functions of these organs?"

"Yes, certainly."

"Again, you might cut off a vine shoot with a carving knife, or chisel, or many other tools?"

"Undoubtedly."

"But with no tool, I imagine, so well as with the pruning knife made for the purpose."

${ }^{1}$ Plato's Republic, Book I. p. 352 E. The translations from The Republic included in this section are all taken from the version of Davies and Vaughan. 


\section{"True."}

"Then shall we not define pruning to be the function of the pruning knife?"

"By all means."

"Now then, I think, you will better understand what I wished to learn from you just now, when I asked whether the function of a thing is not that work for the accomplishment of which it is either the sole or the best instrument?"

"I do understand, and I believe that this is in every case the function of a thing."

"Very well: do you not also think that everything which has an appointed function has also a proper virtue? Let us revert to the same instances; we say that the eyes have a function?"

"They have."

"Then have the eyes a virtue also?"

"They have."

"And the ears: did we assign them a function?"

"Yes."

"Then have they a virtue also?"

"They have."

"And is it the same with all other things?"

"The same."

"Attend then: Do you suppose that the eyes could discharge their own function well if they had not their own proper virtue-that virtue being replaced by a vice?"

"How could they? You mean, probably, if sight is replaced by blindness."

"I mean, whatever their virtue be; for I am not come to that question yet. At present I am asking whether it is through their own peculiar virtue that things per- 
form their proper functions well, and through their own peculiar vice that they perform them ill?"

"You cannot be wrong in that."

"Then if the ears lose their own virtue, will they execute their functions ill?"

"Certainly."

"May we include all other things under the same proposition?"

"I think we may."

"Come, then, consider this point next. Has the soul any function which could not be executed by means of anything else whatsoever? For example, could we in justice assign superintendence and government, deliberation, and the like, to anything but the soul, or should we pronounce them to be peculiar to it?"

"We could ascribe them to nothing else."

"Again, shall we declare life to be a function of the soul?"

"Decidedly."

"Do we not also maintain that the soul has a virtue?" "We do."

"Then can it ever so happen, Thrasymachus, that the soul will perform its functions well when destitute of its own peculiar virtue, or is that impossible?"'

"Impossible."

"Then a bad soul must needs exercise authority and superintendence ill, and a good soul must do all these things well."

THE FOUR CARDINAL VIRTUES

"What ${ }^{2}$ at the commencement we laid down as a universal rule of action, when we were founding our

2 Plato's Republic, Book IV. 433 A. 
state, this, if I mistake not, or some modification of it, is justice. I think we affirmed, if you recollect, and frequently repeated, that every individual ought to have some one occupation in the state, which should be that to which his natural capacity was best adapted."

"We did say so."

"And again, we have often heard people say, that to mind one's own business, and not be meddlesome, is justice; and we have of ten said the same thing ourselves."

"We have said so."

"Then it would seem, my friend, that to do one's own business, in some shape or other, is justice. Do you know whence I infer this?"

"No; be so good as to tell me."

"I think that the remainder left in the state, after eliminating the qualities which we have considered, I mean temperance, and courage, and wisdom, must be that which made their entrance into it possible, and which preserves them there so long as they exist in it. Now we affirmed that the remaining quality, when three out of the four were found, would be justice. . .."

"Here then," I proceeded, " after a hard struggle, we have, though with difficulty, reached the land; and we are pretty well satisfied that there are corresponding divisions, equal in number, in a state, and in the soul of every individual."

"True."

"Then does it not necessarily follow that, as and whereby the state was wise, so and thereby the individual is wise?"

"Without doubt it does."

"And that as and whereby the individual is brave, so and thereby is the state brave; and that everything 
conducing to virtue which is possessed by the one, finds its counterpart in the other?"

"It must be so."

"Then we shall also assert, I imagine, Glaucon, that a man is just, in the same way in which we found the state to be just."

"This too is a necessary corollary."

"But surely we have not allowed ourselves to forget, that what makes the state just, is the fact of each of the three classes therein doing its own work."

"No; I think we have not forgotten this."

"We must bear in mind, then, that each of us also, if his inward faculties do severally their proper work, will, in virtue of that, be a just man, and a doer of his proper work."

"Certainly, it must be borne in mind."

"Is it not then essentially the province of the rational principle to command, inasmuch as it is wise, and has to exercise forethought in behalf of the entire soul, and the province of the spirited principle to be its subject and ally?"

"Yes, certainly."

"And will not the combination of music and gymnastic bring them, as we said, into unison; elevating and fostering the one with lofty discourses and scientific teachings, and lowering the tone of the other by soothing address, till its wildness has been tamed by harmony and rhythm?"

"Yes, precisely so."

"And so these two, having been thus trained, and having truly learned their parts and received a real education, will exercise control over the concupiscent principle, which in every man forms the largest portion 
of the soul, and is by nature most insatiably covetous. And they will watch it narrowly, that it may not so batten upon what are called the pleasures of the body as to grow large and strong, and forthwith refuse to do its proper work, and even aspire to absolute dominion over the classes which it has no right according to its kind to govern, thus overturning fundamentally the life of all."

"Certainly they will."

"And would not these two principles be the best qualified to guard the entire soul and body against enemies from without; the one taking counsel, and the other fighting its battles, in obedience to the governing power, to whose designs it gives effect by its bravery?"

"True."

"In like manner, I think, we call an individual brave, in virtue of the spirited element of his nature, when this part of him holds fast, through pain and pleasure, the instructions of the reason as to what is to be feared, and what is not."

"Yes, and rightly."

"And we call him wise, in virtue of that small part which reigns within him, and issues these instructions, and which also in its turn contains within itself a true knowledge of what is advantageous for the whole community composed of these three principles, and for each member of it."

"Exactly so."

"Again, do we not call a man temperate, in virtue of the friendship and harmony of these same principles, that is to say, when the two that are governed agree with that which governs in regarding the rational principle 
as the rightful sovereign, and set up no opposition to its authority?"

"Certainly," he replied; "temperance is nothing else than this, whether in state or individual."

"Lastly, a man will be just, in the way and by the means which we have repeatedly described."

THE HIGHER EDUCATION LEADING UP TO THE IDEA OF THE GOOD

"WeLL," then, this part of the subject having been laboriously completed, shall we proceed to discuss the questions still remaining, in what way, and by the help of what pursuits and studies, we shall secure the presence of a body of men capable of preserving the constitution unimpaired, and what must be the age at which these studies are severally undertaken?"

"Let us do so, by all means."

"I have gained nothing," I continued, "by my old scheme of omitting the troublesome questions involved in the treatment of the women and children, and the appointment of the magistrates; which I was induced to leave out from knowing what odium the perfectly correct method would incur, and how difficult it would be to carry into effect. Notwithstanding all my precautions, the moment has now arrived when these points must be discussed. It is true the question of the women and children has been already settled, but the inquiry concerning the magistrates must be pursued quite afresh. In describing them, we said, if you recollect, that, in order to place their patriotism beyond the reach of suspicion, they must be tested by pleasure and by pain, and proved never to have deserted their principles in the midst of toil and danger and every vicissitude of fortune,

'Plato's Republic, Book VI. p. 502 D. 
on pain of forfeiting their position if their powers of endurance fail; and that whoever comes forth from the trial without a flaw, like gold tried in the fire, must be appointed to office, and receive, during life and after death, privileges and rewards. This was pretty nearly the drift of our language, which, from fear of awakening the question now pending, turned aside and hid its face."

"Your account is quite correct," he said; "I remember perfectly."

"Yes, my friend, I shrank from making assertions which I have since hazarded; but now let me venture upon this declaration, that we must make the most perfect philosophers guardians."

"We hear you," he replied.

"Now consider what a small supply of these men you will, in all probability, find. For the various members of that character, which we described as essential to philosophers, will seldom grow incorporate: in most cases that character grows disjointed."

"What do you mean?"

"You are aware that persons endowed with a quick comprehension, a good memory, sagacity, acuteness, and their attendant qualities, do not readily grow up to be at the same time so noble and lofty-minded, as to consent to live a regular, calm, and steady life: on the contrary, such persons are drifted by their acuteness hither and thither, and all steadiness vanishes from their life."

"True."

"On the other hand, those steady and invariable characters, whose trustiness makes one anxious to employ them, and who in war are slow to take alarm, 
behave in the same way when pursuing their studies; that is to say, they are torpid and stupid, as if they were benumbed, and are constantly dozing and yawning, whenever they have to toil at anything of the kind."

"That is true."

"But we declare that, unless a person possesses a pretty fair amount of both qualifications, he must be debarred all access to the strictest education, to honor, and to government."

"We are right."

"Then do you not anticipate a scanty supply of such characters?"

"Most assuredly I do."

"Hence we must not be content with testing their behavior in the toils, dangers, and pleasures, which we mentioned before; but we must go on to try them in ways which we then omitted, exercising them in a variety of studies, and observing whether their character will be able to support the highest subjects, or whether it will flinch from the trial, like those who flinch under other circumstances."

"No doubt it is proper to examine them in this way. But pray which do you mean by the highest subjects?"

"I presume you remember, that, after separating the soul into three specific parts, we deduced the several natures of justice, temperance, fortitude, and wisdom?"

"Why, if I did not remember, I should deserve not to hear the rest of the discussion."

"Do you also remember the remark which preceded that deduction?"

"Pray, what was it?"

"We remarked, I believe, that to obtain the best possible view of the question, we should have to take a 
different and a longer route, which would bring us to a thorough insight into the subject: still that it would be possible to subjoin a demonstration of the question, flowing from our previous conclusions. Thereupon you said that such a demonstration would satisfy you; and then followed those investigations which, to my own mind, were deficient in exactness; but you can tell me whether they contented you."

"Well, to speak for myself, I thought them fair in point of measure; and certainly the rest of the party held the same opinion."

"But, my friend, no measure of such a subject, which falls perceptibly short of the truth, can be said to be quite fair, for nothing imperfect is a measure of anything: though people sometimes fancy that enough has been done, and that there is no call for further investigation."

"Yes," he said, "that is a very common habit, and arises from indolence."

"Yes, but it is a habit remarkably undesirable in the guardian of a state and its laws."

"So I should suppose."

"That being the case, my friend, such a person must go round by that longer route, and must labor as devotedly in his studies as in his bodily exercises. Otherwise, as we were saying just now, he will never reach the goal of that highest science, which is most peculiarly his own."

"What!" he exclaimed, "are not these the highest? Is there still something higher than justice and those other things which we have discussed?"

"Even so," I replied; "and here we must not contemplate a rude outline, as we have been doing: on the contrary, we must be satisfied with nothing short of the 
most complete elaboration. For would it not be ridiculous to exert one's self on other subjects of small value, taking all imaginable pains to bring them to the most exact and spotless perfection; and at the same time to ignore the claim of the highest subjects to a corresponding exactitude of the highest order?"

"The sentiment is a very just one. But do you suppose that any one would let you go without asking what that science is which you call the highest, and of what it treats?"

"Certainly not," I replied; "so put the question yourself. Assuredly you have heard the answer many a time; but at this moment either you have forgotten it, or else you intend to find me employment by raising objections. I incline to the latter opinion; for you have of ten been told that the essential Form of the Good ( $\dot{\eta}$ rov $\dot{a} \gamma a \theta o v$ i $\left.\delta \delta^{\prime} a\right)$ is the highest object of science, and that this essence, by blending with just things and all other created objects, renders them useful and advantageous. And at this moment you can scarcely doubt that I am going to assert this, and to assert, besides, that we are not sufficiently acquainted with this essence. And if so,-if, I say, we know everything else perfectly, without knowing this,-you are aware that it will profit us nothing; just as it would be equally profitless to possess everything without possessing what is good. Or do you imagine it would be a gain to possess all possessible things, with the single exception of things good; or to apprehend every conceivable object, without apprehending what is good,in other words, to be destitute of every good and beautiful conception?"

"Not I, believe me."

"Moreover, you doubtless know besides, that the chief 
good is supposed by the multitude to be pleasure,-by the more enlightened, insight?"

"Of course I know that."

"And you are aware, my friend, that the advocates of this latter opinion are unable to explain what they mean by insight, and are compelled at last to explain it as insight into that which is good."

"Yes, they are in a ludicrous difficulty."

"They certainly are: since they reproach us with ignorance of that which is good, and then speak to us the next moment as if we knew what it was. For they tell us that the chief good is insight into good, assuming that we understand their meaning, as soon as they have uttered the term 'good." "

"It is perfectly true."

"Again: are not those, whose definition identifies pleasure with good, just as much infected with error as the preceding? For they are forced to admit the existence of evil pleasures, are they not?"

"Certainly they are."

"From which it follows, I should suppose, that they must admit the same thing to be both good and evil. Does it not?"

"Certainly it does."

"Then is it not evident that this is a subject of ten and severely disputed?"

"Doubtless it is."

"Once more: is it not evident, that though many persons would be ready to do and seem to do, or to possess and seem to possess, what seems just and beautiful, without really being so; yet, when you come to things good, no one is content to acquire what only seems such; on the contrary, everybody seeks the reality, 
and semblances are here, if nowhere else, treated with universal contempt?"

"Yes, that is quite evident."

"This good, then, which every soul pursues, as the end of all its actions, divining its existence, but perplexed and unable to apprehend satisfactorily its nature, or to enjoy that steady confidence in relation to it which it does enjoy in relation to other things, and therefore doomed to forfeit any advantage which it might have derived from those same things;- are we to maintain that, on a subject of such overwhelming importance, the blindness we have described is a desirable feature in the character of those best members of the state in whose hands everything is to be placed?"

"Most certainly not."

"At any rate, if it be not known in what way just things and beautiful things come to be also good, I imagine that such things will not possess a very valuable guardian in the person of him who is ignorant on this point. And I surmise that none will know the just and the beautiful satisfactorily till he knows the good."

"You are right in your surmises."

"Then will not the arrangement of our constitution be perfect, provided it be overlooked by a guardian who is scientifically acquainted with these subjects?"

"Unquestionably it will."

THE IDEA OF THE GOOD AS THE SOURCE OF TRUTH AND OF REALITY

"Pray," Socrates, do you assert the chief good to be science or pleasure or something different from either?" "Ho, ho, my friend! I saw long ago that you would

- Plato's Republic, p. 506 B. 
certainly not put up with the opinions of other people on these subjects."

"Why, Socrates, it appears to me to be positively wrong in one who has devoted so much time to these questions, to be able to state the opinions of others, without being able to state his own."

"Well," I said, "do you think it right to speak with an air of information on subjects on which one is not well informed?"

"Certainly not with an air of information; but I think it right to be willing to state one's opinion for what it is worth."

"Well, but have you not noticed that opinions divorced from science are all ill-favored? At the best they are blind. Or do you conceive that those who, unaided by the pure reason, entertain a correct opinion, are at all superior to blind men, who manage to keep the straight path?"

"Not at all superior," he replied.

"Then is it your desire to contemplate objects that are ill-favored, blind, and crooked, when it is in your power to learn from other people about bright and beautiful things?"

"I implore you, Socrates," cried Glaucon, "not to hang back, as if you had come to the end. We shall be content even if you only discuss the subject of the chief good in the style in which you discussed justice, temperance, and the rest."

"Yes, my friend, and I likewise shou'd be thoroughly content. But I distrust my own powers, and I feel afraid that my awkward zeal will subject me to ridicule. No, my good sirs: let us put aside, for the present at any rate, all inquiry into the real nature of the chief good. For, methinks, it is beyond the measure of this our 
enterprise to find the way to what is, after all, only my present opinion on the subject. But I am willing to talk to you about that which appears to be an offshoot of the chief good, and bears the strongest resemblance to it, provided it is also agreeable to you; but if it is not, I will let it alone."

"Nay, tell us about it," he replied. "You shall remain in our debt for an account of the parent."

"I wish that $I$ could pay, and you receive, the parent sum, instead of having to content ourselves with the interest springing from it. However, here I present you with the fruit and scion of the essential good. Only take care that I do not involuntarily impose upon you by handing in a forged account of this offspring."

"We will take all the care we can; only proceed."

"I will do so, as soon as we have come to a settlement together, and you have been reminded of certain statements made in a previous part of our conversation, and renewed before now again and again."

"Pray what statements?"

"In the course of the discussion we have distinctly maintained the existence of a multiplicity of things that are beautiful, and good, and so on."

"True, we have."

"And also the existence of an essential beauty, and an essential good, and so on;-reducing all those things which before we regarded as manifold, to a single form and a single entity in each case, and addressing each as an independent being."

"Just so."

"And we assert that the former address themselves to the eye, and not to the pure reason; whereas the forms address themselves to the reason, and not to the eye." 
"Certainly."

"Now with what part of ourselves do we see visible objects?"

"With the eyesight."

"In the same way we hear sounds with the hearing, and perceive everything sensible with the other senses, do we not?"

"Certainly."

"Then have you noticed with what transcendent costliness the architect of the senses has wrought out the faculty of seeing and being seen?"

"Not exactly," he replied.

"Well, then, look at it in this light. Is there any other kind of thing which the ear and the voice require to enable the one to hear, and the other to be heard, in the absence of which third thing the one will not hear, and the other will not be heard?"

"No, there is not."

"And I believe that very few, if any, of the other senses require any such third thing. Can you mention one that does?"

"No, I cannot."

"But do you not perceive that, in the case of vision and visible objects, there is a demand for something additional?"

"How so?"

"Why, granting that vision is seated in the eye, and that the owner of it is attempting to use it, and that color is resident in the objects, still, unless there be present a third kind of thing, devoted to this especial purpose, you are aware that the eyesight will see nothing, and the colors will be invisible."

"Pray what is the third thing to which you refer?" 
"Of course I refer to what you call light."

"You are right."

"Hence it appears, that of all the pairs aforesaid, the sense of sight, and the faculty of being seen, are coupled by the noblest link, whose nature is anything but insignificant, unless light is an ignoble thing."

"No, indeed; it is very far from being ignoble."

"To whom, then, of the gods in heaven can you refer as the author and dispenser of this blessing? And whose light is it that enables our sight to see so excellently well, and makes visible objects appear?"

"There can be but one opinion on the subject," he replied: "your question evidently alludes to the sun."

"Then the relation subsisting between the eyesight and this deity is of the following nature, is it not?"

"Describe it."

"Neither the sight itself, nor the eye, which is the seat of sight, can be identified with the sun."

"Certainly not."

"And yet, of all the organs of sensation, the eye, methinks, bears the closest resemblance to the sun."

"Yes, quite so."

"Further, is not the faculty which the eye possesses dispensed to it from the sun, and held by it as something adventitious?"

"Certainly it is."

"Then is it not also true, that the sun, though not identical with sight, is nevertheless the cause of sight, and is moreover seen by its aid?"

"Yes, quite true."

"Well then," I continued, "believe that I meant the sun, when I spoke of the offspring of the chief good, begotten by it in a certain resemblance to itself,-that is to 
say, bearing the same relation in the visible world to sight and its objects, which the chief good bears in the intellectual world to pure reason and its objects."

"How so? Be so good as to explain it to me more at length."

"Are you aware, that whenever a person makes an end of looking at objects, upon which the light of day is shedding color, and looks instead at objects colored by the light of the moon and stars, his eyes grow dim and appear almost blind, as if they were not the seat of distinct vision?"

"I am fully aware of it."

"But whenever the same person looks at objects on which the sun is shining, these very eyes, I believe, see clearly, and are evidently the seat of distinct vision?"

"Unquestionably it is so."

"Just in the same way understand the condition of the soul to be as follows: Whenever it has fastened upon an object, over which truth and real existence are shining, it seizes that object by an act of reason, and knows it, and thus proves itself to be possessed of reason: but whenever it has fixed upon objects that are blent with darkness, - the world of birth and death, - then it rests in opinion, and its sight grows dim, as its opinions shift backward and forward, and it has the appearance of being destitute of reason."

"True, it has."

"Now, this power, which supplies the objects of real knowledge with the truth that is in them, and which renders to him who knows them the faculty of knowing them, you must consider to be the essential Form of Good ( the origin of science, and of truth, so far as the latter 
comes within the range of knowledge: and though knowledge and truth are both very beautiful things, you will be right in looking upon good as something distinct from them, and even more beautiful. And just as, in the analogous case, it is right to regard light and vision as resembling the sun, but wrong to identify them with the sun; so, in the case of science and truth, it is right to regard both of them as resembling good, but wrong to identify either of them with good; because, on the contrary, the quality of the good ought to have a still higher value set upon it."

"That implies an inexpressible beauty, if it not only is the source of science and truth, but also surpasses them in beauty; for, I presume, you do not mean by it pleasure."

"Hush!" I exclaimed, "not a word of that. But you had better examine the illustration further, as follows."

"Show me how."

"I think you will admit that the sun ministers to visible objects, not only the faculty of being seen, but also their vitality, growth, and nutriment, though it is not itself equivalent to vitality."

"Of course it is not."

"Then admit that, in like manner, the objects of knowledge not only derive from the good the gift of being known, but are further endowed by it with a real and essential existence; though the good, far from being identical with real existence, actually transcends it in dignity and power."

Hereupon Glaucon exclaimed with a very amusing air, "Good heavens! what a miraculous superiority!"

"Well," I said, "you are the person to blame, because you compel me to state my opinions on the subject."

"Nay, let me entreat you not to stop, till you have at 
all events gone over again your similitude of the sun, if you are leaving anything out."

"Well, to say the truth, I am leaving out a great deal."

"Then pray do not omit even a trifle."

"I fancy I shall leave much unsaid; however, if I can help it under the circumstances, I will not intentionally make any omission."

"Pray do not."

REALITY AND APPEARANCE-KNOWLEDGE AND OPINION

"Now ${ }^{5}$ understand that, according to us, there are two powers reigning, one over an intellectual, and the other over a visible region and class of objects;--if I were to use the term 'firmament' you might think I was playing on the word. Well, then, are you in possession of these as two kinds,-one visible, the other intellectual?"

"Yes, I am."

"Suppose you take a line divided into two unequal parts, - one to represent the visible class of objects, the other the intellectual,- - and divide each part again into two segments on the same scale. Then, if you make the lengths of the segments represent degrees of distinctness or indistinctness, one of the two segments of the part which stands for the visible world will represent all images: meaning, by images, first of all, shadows; and, in the next place, reflections in water, and in closegrained, smooth, bright substances, and everything of the kind, if you understand me."

"Yes, I do understand."

"Let the other segment stand for the real objects corresponding to these images,--namely, the animals about us, and the whole world of nature and of art."

'Plato's Republic, p. 509 D. 
"Very good."

"Would you also consent to say that, with reference to this class, there is, in point of truth and untruthfulness, the same distinction between the copy and the original, that there is between what is matter of opinion and what is matter of knowledge?"

"Certainly I should."

"Then let us proceed to consider how we must divide that part of the whole line which represents the intellectual world."

"How must we do it?"

"Thus: one segment of it will represent what the soul is compelled to investigate by the aid of the segments of the other part, which it employs as images, starting from hypotheses, and travelling not to a first principle, but to a conclusion. The other segment will represent the objects of the soul, as it makes its way from an hypothesis to a first principle which is not hypothetical, unaided by those images which the former division employs, and shaping its journey by the sole help of real essential forms."

"I have not understood your description so well as I could wish."

"Then we will try again. You will understand me more easily when I have made some previous observations. I think you know that the students of subjects like geometry and calculation, assume by way of materials, in each investigation, all odd and even numbers, figures, three kinds of angles, and other similar data. These things they are supposed to know, and having adopted them as hypotheses, they decline to give any account of them, either to themselves or to others, on the assumption that they are self-evident; and, making 
these their starting point, they proceed to travel through the remainder of the subject, and arrive at last, with perfect unanimity, at that which they have proposed as the object of investigation."

"I am perfectly aware of the fact," he replied.

"Then you also know that they summon to their aid visible forms, and discourse about them, though their thoughts are busy not with these forms, but with their originals, and though they discourse not with a view to the particular square and diameter which they draw, but with a view to the absolute square and the absolute diameter, and so on. For while they employ by way of images those figures and diagrams aforesaid, which again have their shadows and images in water, they are really endeavoring to behold those abstractions which a person can only see with the eye of thought."

"True."

"This, then, was the class of things which I called intellectual; but I said that the soul is constrained to employ hypotheses while engaged in the investigation of them,-not travelling to a first principle (because it is unable to step out of, and mount above, its hypotheses), but using, as images, just the copies that are presented by things below,-which copies, as compared with the originals, are vulgarly esteemed distinct and valued accordingly."

"I understand you to be speaking of the subject-matter of the various branches of geometry and the kindred arts."

"Again, by the second segment of the intellectual world understand me to mean all that the mere reasoning process apprehends by the force of dialectic, when it avails itself of hypotheses not as first principles, but as 
genuine hypotheses, that is to say, as stepping-stones and impulses, whereby it may force its way up to something that is not hypothetical, and arrive at the first principle of everything, and seize it in its grasp; which done, it turns round, and takes hold of that which takes hold of this first principle, till at last it comes down to a conclusion, calling in the aid of no sensible object whatever, but simply employing abstract, self-subsisting forms, and terminating in the same."

"I do not understand you so well as I could wish, for I believe you to be describing an arduous task; but at any rate I understand that you wish to declare distinctly, that the field of real existence and pure intellect, as contemplated by the science of dialectic, is more certain than the field investigated by what are called the arts, in which hypotheses constitute first principles, which the students are compelled, it is true, to contemplate with the mind and not with the senses; but, at the same time, as they do not come back, in the course of inquiry, to a first principle, but push on from hypothetical premises, you think that they do not exercise pure reason on the questions that engage them, although taken in connection with a first principle these questions come within the domain of the pure reason. And I believe you apply the term understanding, not pure reason, to the mental habit of such people as geometricians,--regarding understanding as something intermediate between opinion and pure reason."

"You have taken in my meaning most satisfactorily; and I beg you will accept these four mental states, as corresponding to the four segments,-namely, pure reason corresponding to the highest, understanding to the second, belief to the third, and conjecture to the last; 
and pray arrange them in gradation, and believe them to partake of distinctness in a degree corresponding to the truth of their respective objects."

"I understand you," said he. "I quite agree with you, and will arrange them as you desire."

THE ALLEGORY OF THE DEN-SHADOWS AND REALITIES

"Now ${ }^{6}$ then," I proceeded to say, "go on to compare our natural condition, so far as education and ignorance are concerned, to a state of things like the following. Imagine a number of men living in an underground cavernous chamber, with an entrance open to the light, extending along the entire length of the cavern, in which they have been confined, from their childhood, with their legs and necks so shackled that they are obliged to sit still and look straight forward, because their chains render it impossible for them to turn their heads round; and imagine a bright fire burning some way off, above and behind them, and an elevated roadway passing between the fire and the prisoners, with a low wall built along it, like the screens which conjurers put up in front of their audience, and above which they exhibit their wonders."

"I have it," he replied.

"Also figure to yourself a number of persons walking behind this wall, and carrying with them statues of men, and images of other animals, wrought in wood and stone and all kinds of materials, together with various other articles, which overtop the wall; and, as you might expect, let some of the passers-by be talking, and others silent."

"You are describing a strange scene, and strange prisoners."

- Plato's Republic, Book VII. p. 514 D. 
"They resemble us," I replied. "For let me ask you, in the first place, whether persons so confined could have seen anything of themselves or of each other, beyond the shadows thrown by the fire upon the part of the cavern facing them?"

"Certainly not, if you suppose them to have been compelled all their lifetime to keep their heads unmoved."

"And is not their knowledge of the things carried past them equally limited?"

"Unquestionably it is."

"And if they were able to converse with one another, do you not think that they would be in the habit of giving names to the objects which they saw before them?"

"Doubtless they would."

"Again: if their prison-house returned an echo from the part facing them, whenever one of the passers-by opened his lips, to what, let me ask you, could they refer the voice, if not to the shadow which was passing?"

"Unquestionably they would refer it to that."

"Then surely such persons would hold the shadows of those manufactured articles to be the only realities."

"Without doubt they would."

"Now consider what would happen if the course of nature brought them a release from their fetters, and a remedy for their foolishness, in the following manner: Let us suppose that one of them has been released, and compelled suddenly to stand up, and turn his neck round and walk with open eyes toward the light; and let us suppose that he goes through all these actions with pain, and that the dazzling splendor renders him incapable of discerning those objects of which he used formerly to see the shadows. What answer should you expect him to make, if some one were to tell him that in those days 
he was watching foolish phantoms, but that now he is somewhat nearer to reality, and is turned toward things more real, and sees more correctly; above all, if he were to point out to him the several objects that are passing by, and question him, and compel him to answer what they are? Should you not expect him to be puzzled, and to regard his old visions as truer than the objects now forced upon his notice?"

"Yes, much truer."

"And if he were further compelled to gaze at the light itself, would not his eyes, think you, be distressed, and would he not shrink and turn away to the things which he could see distinctly, and consider them to be really clearer than the things pointed out to him?"

"Just so."

"And if some one were to drag him violently up the rough and steep ascent from the cavern, and refuse to let him go till he had drawn him out into the light of the sun, would he not, think you, be vexed and indignant at such treatment, and on reaching the light, would he not find his eyes so dazzled by the glare as to be incapable of making out so much as one of the objects that are now called true?"

"Yes, he would find it so at first."

"Hence, I suppose, habit will be necessary to enable him to perceive objects in that upper world. At first he will be most successful in distinguishing shadows; then he will discern the reflections of men and other things in water, and afterward the realities; and after this he will raise his eyes to encounter the light of the moon and stars, finding it less difficult to study the hesvenly bodies and the heaven itself by night, than the sun and the sun's light by day." 
"Doubtless."

"Last of all, I imagine, he will be able to observe and contemplate the nature of the sun, not as it appears in water or on alien ground, but as it is in itself in its own territory."

"Of course."

"His next step will be to draw the conclusion, that the sun is the author of the seasons and the years, and the guardian of all things in the visible world, and in a manner the cause of all those things which he and his companions used to see."

"Obviously, this will be his next step."

"What then? When he recalls to mind his first habitation, and the wisdom of the place, and his old fellow-prisoners, do you not think he will congratulate himself on the change, and pity them?"

"Assuredly he will."

"And if it was their practice in those days to receive honor and commendations one from another, and to give prizes to him who had the keenest eye for a passing object, and who remembered best all that used to precede and follow and accompany it, and from these data divined most ably what was going to come next, do you fancy that he will covet these prizes, and envy those who receive honor and exercise authority among them? Do you not rather imagine that he will feel what Homer describes, and wish extremely

'To drudge on the lands of a master,

Under a portionless wight,'

and be ready to go through anything, rather than entertain those opinions, and live in that fashion?"

"For my own part," he replied, "I am quite of that 
opinion. I believe he would consent to go through anything rather than live in that way."

"And now consider what would happen if such a man were to descend again and seat himself on his old seat? Coming so suddenly out of the sun, would he not find his eyes blinded with the gloom of the place?"

"Certainly, he would."

"And if he were forced to deliver his opinion again, touching the shadows aforesaid, and to enter the lists against those who had always been prisoners, while his sight continued dim, and his eyes unsteady, - and if this process of initiation lasted a considerable time, would he not be made a laughing-stock, and would it not be said of him, that he had gone up only to come back again with his eyesight destroyed, and that it was not worth while even to attempt the ascent? And if any one endeavored to set them free and carry them to the light, would they not go so far as to put him to death, if they could only manage to get him into their power?"

"Yes, that they would."

"Now this imaginary case, my dear Glaucon, you must apply in all its parts to our former statements, by comparing the region which the eye reveals to the prisonhouse, and the light of the fire therein to the power of the sun: and if, by the upward ascent and the contemplation of the upper world, you understand the mounting of the soul into the intellectual region, you will hit the tendency of my own surmises, since you desire to be told what they are; though, indeed, God only knows whether they are correct. But, be that as it may, the view which I take of the subject is to the following effect: In the world of knowledge, the essential Form of Good ( $\dot{\eta} \tau o \hat{v}$ áya $\left.\theta o \hat{v} i \delta^{\prime} \boldsymbol{a} a\right)$ is the limit of our inquiries, and can barely be 
perceived; but, when perceived, we cannot help concluding that it is in every case the source of all that is bright and beautiful,-in the visible world giving birth to light and its master, and in the intellectual world dispensing, immediately and with full authority, truth and reason; and that, whosoever would act wisely, either in private or in public, must set this Form of Good before his eyes."

"To the best of my power," said he, "I quite agree with you."

"That being the case," I continued, "pray agree with me on another point, and do not be surprised that those who have climbed so high are unwilling to take a part in the affairs of men, because their souls are ever loath to desert that upper region. For how could it be otherwise, if the preceding simile is indeed a correct representation of their case?"

"True, it could scarcely be otherwise."

"Well: do you think it a marvellous thing, that a person who has just quitted the contemplation of divine objects for the study of human infirmities should betray awkwardness, and appear very ridiculous, when with his sight still dazed, and before he has become sufficiently habituated to the darkness that reigns around, he finds himself compelled to contend in courts of law, or elsewhere, about the shadows of justice, or images which throw the shadows, and to enter the lists in questions involving the arbitrary suppositions entertained by those who have never yet had a glimpse of the essential features of justice?"

"No, it is anything but marvellous."

"Right: for a sensible man will recollect that the eyes may be confused in two distinct ways and from two distinct causes-that is to say, by sudden transitions 
either from light to darkness, or from darkness to light. And, believing the same idea to be applicable to the soul, whenever such a person sees a case in which the mind is perplexed and unable to distinguish objects, he will not laugh irrationally, but he will examine whether it has just quitted a brighter life, and has been blinded by the novelty of darkness, or whether it has come from the depths of ignorance into a more brilliant life, and has been dazzled by the unusual splendor; and not till then will he congratulate the one upon its life and condition, and compassionate the other; and if he chooses to laugh at it, such laughter will be less ridiculous than that which is raised at the expense of the soul that has descended from the light of a higher region."

"You speak with great judgment."

"Hence, if this be true, we cannot avoid adopting the belief, that the real nature of education is at variance with the account given of it by certain of its professors, who pretend, I believe, to infuse into the mind a knowledge of which it was destitute, just as sight might be instilled nto blinded eyes."

"True; such are their pretensions."

"Whereas, our present argument shows us that there is a faculty residing in the soul of each person, and an instrument enabling each of us to learn; and that, just as we might suppose it to be impossible to turn the eye round from darkness to light without turning the whole body, so must this faculty, or this instrument, be wheeled round, in company with the entire soul, from the perishing world, until it be enabled to endure the contemplation of the real world and the brightest part thereof, which, according to us, is the Form of Good. Am I not right?" 
"You are."

"Hence," I continued, "this very process of revolution must give rise to an art, teaching in what way the change will most easily and most effectually be brought about. Its object will not be to generate in the person the power of seeing. On the contrary, it assumes that he possesses it, though he is turned in a wrong direction, and does not look toward the right quarter; and its aim is to remedy this defect."

"So it would appear."

"Hence, while, on the one hand, the other so-called virtues of the soul seem to resemble those of the body, inasmuch as they really do not preëxist in the soul, but are formed in it in the course of time by habit and exercise; the virtue of wisdom, on the other hand, does most certainly appertain, as it would appear, to a more divine substance, which never loses its energy, but by change of position becomes useful and serviceable, or else remains useless and injurious. For you must, ere this, have noticed how keen-sighted are the puny souls of those who have the reputation of being clever but vicious, and how sharply they see through the things to which they are directed, thus proving that their powers of vision are by no means feeble, though they have been compelled to become the servants of wickedness, so that the more sharply they see, the more numerous are the evils which they work."

"Yes, indeed, it is the case."

"But," I proceeded, "if from earliest childhood these characters had been shorn and stripped of those leaden, earth-born weights, which grow and cling to the pleasures of eating and gluttonous enjoyments of a similar nature, and keep the eye of the soul turned upon the things 
below; if, I repeat, they had been released from these snares, and turned round to look at objects that are true, then these very same souls of these very same men would have had as keen an eye for such pursuits as they actually have for those in which they are now engaged." "Yes, probably it would be so."

"Once more: is it not also probable, or rather is it not a necessary corollary to our previous remarks, that neither those who are uneducated and ignorant of truth, nor those who are suffered to linger over their education all their life, can ever be competent overseers of a state,the former, because they have no single mark in life, which they are to constitute the end and aim of all their conduct both in private and in public; the latter, because they will not act without compulsion, fancying that, while yet alive, they have been translated to the islands of the blest."

"That is true."

"It is, therefore, our task," I continued, "to constrain the noblest characters in our colony to arrive at that science which we formerly pronounced the highest, and to set eyes upon the good, and to mount that ascent we spoke of ; and, when they have mounted and looked long enough, we must take care to refuse them that liberty which is at present permitted them."

"Pray what is that?"

"The liberty of staying where they are, and refusing to descend again to those prisoners, or partake of their toils and honors, be they mean or be they exalted."

"Then are we to do them a wrong, and make them live a life that is worse than the one within their reach?"

"You have again forgotten, my friend, that the law does not ask itself how some one class in a state is to live 
extraordinarily well. On the contrary, it tries to bring about this result in the entire state; for which purpose it links the citizens together by persuasion and by constraint, makes them share with one another the benefit which each individual can contribute to the common weal, and does actually create men of this exalted character in the state, not with the intention of letting them go each on his own way, but with the intention of turning them to account in its plans for the consolidation of the state."

"True," he replied; "I had forgotten."

"Therefore reflect, Glaucon, that far from wronging the future philosophers of our state, we shall only be treating them with strict justice, if we put them under the additional obligation of watching over their fellowcitizens, and taking care of them.... And in this way you and we shall find that the life of the state is a substance, and not a phantom like the life of our present states, which are mostly composed of men who fight among themselves for shadows, and are at feud for the administration of affairs, which they regard as a great boon. Whereas I conceive the truth stands thus: That city in which the destined rulers are least eager to rule, will inevitably be governed in the best and least factious manner, and a contrary result will ensue if the rulers are of a contrary disposition. . . . But if beggars, and persons who hunger after private advantages, take the reins of the state, with the idea that they are privileged to snatch advantage from their power, all goes wrong. For the post of magistrate is thus made an object of strife; and civil and intestine conflicts of this nature ruin not only the contending parties, but also the rest of the state." 
[The allegory of the den suggests the question: How is the soul drawn upward from the shifting shadows of sense to the eternal world of reality? Plato, through Socrates, points out that the contradictions and confusions of our sense-impressions stimulate reflection. The application of number, fixing, as it were, the "one in many," begins to bring order out of chaos. The development of the sciences,-arithmetic, geometry, astronomy,-further tends to draw the soul upward to the intelligible world, and this process is finally completed by dialectic, the nature and function of dialectic being thus described:]

"Whenever ${ }^{7}$ a person strives, by the help of dialectic, to start in pursuit of every reality by a simple process of reason, independent of all sensuous information,--never flinching, until by an act of the pure intelligence he has grasped the real nature of good,--he arrives at the very end of the intellectual world, just as the last-mentioned person arrived at the end of the visible world."

"Unquestionably."

"And this course you name dialectic, do you not?"

"Certainly I do."

"On the other hand, the release of the prisoners from their chains, and their transition from the shadows of the images to the images themselves and to the light, and their ascent from the cavern into the sunshine;-and, when there, the fact of their being able to look, not at the animals and vegetables and the sun's light, but still only at their reflections in water, which are indeed divine and shadows of things real, instead of being shadows of images thrown by a light which may itself be called an

'Plato's Republic, p. 532 A. 


\section{SOURCE BOOK IN ANCIENT PHILOSOPHY}

image, when compared with the sun;--these points, I say, find their counterpart in all this pursuit of the abovementioned arts, which possesses this power of elevating the noblest part of the soul, and advancing it toward the contemplation of that which is most excellent in the things that really exist, just as in the other case the clearest organ of the body was furthered to the contemplation of that which is brightest in the corporeal and visible region. . . . And may I not also affirm, that the faculty of dialectic can alone reveal the truth to one who is master of the sciences which we have just enumerated; and that in no other way is such knowledge possible?"

"Yes, on that point also you are warranted in speaking positively."

"At any rate," I continued, "no one will contradict us when we assert that there is no other method which attempts systematically to form a conception of the real nature of each individual thing. On the contrary, all the arts, with a few exceptions, are wholly addressed to the opinions and wants of men, or else concern themselves about the production and composition of bodies, or the treatment of things which grow and are compounded. And as for these few exceptions, such as geometry and its accompanying sciences, which, accord-

- ing to us, in some small degree apprehend what is real,we find that, though they may dream about real existence, they cannot behold it in a waking state, so long as they use hypotheses which they leave unexamined, and of which they can give no account. For when a person assumes a first principle which he does not know, on which unknown first principle depends the web of intermecliate propositions, and the final conclusion,- -by what 
possibility can such mere admissions ever constitute science?"

"It is indeed impossible."

"Hence the dialectic method, and that alone, adopts the following course. It carries back its hypotheses to the very first principle of all, in order to establish them firmly; and finding the eye of the soul absolutely buried in a swamp of barbarous ignorance, it gently draws and raises it upward, employing as handmaids in this work of revolution the arts which we have discussed. These we have often called sciences, because it is customary to do so, but they require another name, betokening greater clearness than opinion, but less distinctness than science. On some former occasion we fixed upon the term understanding to express this mental process. But it appears to me to be no part of our business to dispute about a name, when we have proposed to ourselves the consideration of such important subjects."

"You are quite right," said he: "we only want a name which when applied to a mental state shall indicate clearly what phenomena it describes."

"Indeed, I am content," I proceeded, " to call as before the first division science, the second understanding, the third belief, and the fourth conjecture,-the two latter jointly constituting opinion, and the two former intelligence. Opinion deals with the changing, intelligence with the real; and as the real is to the changing, so is intelligence to opinion; and as intelligence is to opinion, so is science to belief, and understanding to conjecture. ...

"Do you also give the title of Dialectician to the person who takes thoughtful account of the essence of each thing? And will you admit that, so far as a person has 
no such account to give to himself and to others, so far he fails to exercise pure reason upon the subject?"

"Yes, I cannot doubt it," he replied.

"Then shall you not also hold the same language concerning the good? Unless a person can strictly define by a process of thought the essential Form of the Good, abstracted from everything else; and unless he can fight his way as it were through all objections, studying to disprove them not by the rules of opinion, but by those of real existence; and unless in all these conflicts he travels to his conclusion without making one false step in his train of thought,- - unless he does all this, shall you not assert that he knows neither the essence of good, nor any other good thing; and that any phantom of it, which he may chance to apprehend, is the fruit of opinion and not of science; and that he dreams and sleeps away his present life, and never wakes on this side of that future world, in which he is doomed to sleep forever? ... Then does it not seem to you that dialectic lies, like a coping-stone, upon the top of the sciences, and that it would be wrong to place any other science above it. because the series is now complete?" 


\section{XIV}

\section{ARISTOTLE}

[884-322 в.с.]

\section{ORIGIN AND NATURE OF PHILOBOPHT}

IT ${ }^{1}$ was owing to wonder that men began to philosophize in earlier times just as it is to-day, wondering at first about the problems that lie close at hand, and then little by little advancing to the greater perplexities, such as the phenomena of the moon and sun and stars, and the creation of the universe. But one who is perplexed and filled with wonder feels himself to be in ignorance, and so the lover of the myth is in a way the lover of wisdom, for the myth too is made of marvels. And so if men philosophized in order to escape ignorance it is evident that they pursued wisdom just for the sake of knowing, not for the sake of any advantage it might bring. This is shown too by the course of events. For it was only after practically all things that are necessary for the comfort and convenience of life had been provided that this kind of knowledge began to be sought. Clearly then we pursue this knowledge for the sake of no extraneous use to which it may be put, but, just as we call a man free who serves his own and not another's will, so also this science is the only one of all the sciences that is liberal, for it is the only one that exists for its own sake. . . . More necessary, indeed, every other science may be than this, more excellent there is nono.

1 Arist. Met. I. 2, 982 b 12. 
But ${ }^{2}$ somehow the possession of this knowledge inevitably brings us to a position precisely the opposite of that in which we were at the beginning of our investigations. For, as I have said, we all begin by wondering that things are as they are, just as marionettes, or again such things as the turnings of the sun or the incommensurability of the diameter are wonderful to those who do not yet understand the cause; for every one is filled with astonishment on first hearing that there is anything which cannot be measured if the unit of measurement be made small enough. And yet in the end our position is reversed, and "after-thinking is best," as the proverb has it; and so it is in the cases before us when once we reach knowledge. For nothing would so astonish the geometrician as to discover that the diagonal was commensurate with the side.

\section{$*^{*}{ }^{*}$}

Science ${ }^{3}$ arises whenever from a number of notions derived from experience a universal conception is formed comprising all similar cases. To have the conception that when Kallias was sick of such and such a disease such and such a remedy did him good, and the same of Socrates and of many others taken one by one, is the part of experience; but to know that it did good to all such persons comprised in one and the same class, afflicted with the same disease, such as inflammation, or biliousness, or burning fever, is the part of science. In actually achieving results experience is apparently not inferior to science. On the contrary we often find men of experience more successful in reaching their aim than men who have the theory without the experience.

2 Arist. Met. I. 2. 983 a 11.

:Ib. I. 1, 981 a 5. 
The reason for this is that experience is knowledge of individual cases, whereas science is knowledge of universal principles, and every action and every creative process has to do with individual cases. For example, the physician does not heal mankind, except incidentally, but rather Kallias or Socrates or some other similar individual who happens, to be sure, also to belong to the genus homo. If, then, one possesses the theory without the experience, and has a knowledge of the general principles, but does not know how to apply them in the individual case before him, he will very of ten make a mistake as to the cure required; for it is always the individual case that is to be cured.

Nevertheless we think that knowledge and understanding are properties of science rather than of experience, and we hold men of science to be wiser than men of experience on the ground that in every case wisdom is to be ascribed to one in proportion to the extent of his knowledge. And the reason why we do this is because the former know the reason why, the latter do not; men of experience know the fact, men of science know the wherefore of the fact. . . .

In general the mark of knowledge is ability to impart what one knows to others; and this is why we hold science to be a higher form of knowledge than experience, men of science being able, men of experience being unable to impart their knowledge to others.

Furthermore, we do not attribute wisdom to any of the senses although they are, it is true, the chief means of knowing individual cases. But they do not tell us the wherefore of any fact, as for example, why fire is hot, but simply that it is hot. Consequently it was natural that the first man who discovered any science whatso- 
ever that went beyond the knowledge of the senses which is common to all, was the wonder and admiration of his fellow-men, not only because there was something useful in his discoveries, but because they held him to be a wise man and superior to his fellows. And as more and more of the sciences are discovered, some having to do with the necessities, others with the comforts of life, we always hold men who discovered the latter to be wiser than those who discovered the former, just because in their case knowledge has nothing to do with utility. Whence it came about that when all the different sciences of these two sorts had been discovered the sciences were discovered which have nothing to do either with the pleasures or the necessities of life, and first of all in those places where men had leisure. This is why the mathematical sciences were developed first of all in the neighborhood of Egypt, for there the priestly class was left with plenty of leisure. . . . All men understand as the object of what is called wisdom knowledge of ultimate causes and first principles, so that, as we said before, the man of experience is superior in point of wisdom to the man who merely trusts his senses, whatever the sense may be, and the man of science is superior to the man of experience, the architect to the manual laborer, theory to practice. It is evident from all this that wisdom is the knowledge of causes and first principles of some kind or other.

\section{ARISTOTLE'S CRITICISM OF THE THIORT OF IDEAS}

With 4 regard to the philosophers who introduced ideas as causes we have in the first place this objection to offer, that in seeking to find an explanation of the things

- Arist. Met. I. 9, 990 \& 34. 
that exist they have introduced other realities equal in number; just as if one should try to count a number of objects, and should suppose that he could not do so if the number were small, but that he would have no diffculty if he made the number larger. For the ideas are practically equal in number to, - at any rate they are not less than, the things for the explanation of which they had recourse to the world of ideas. For every individual object has its synonymous reality, and over and above actual existences there are ideas of all other things wherever there is a "one in many," both in the changeable things of this world and in the eternal.

The second objection we have to offer is that of all the proofs which we bring forward for the existence of ideas there is no real evidence; for in the case of some of our arguments the conclusion does not necessarily follow, and in the case of others, ideas are also proved to exist for things for which we do not assume the existence of any ideas. For example, from the proofs which are taken from the existence of the various sciences there will be ideas of all things whatever which can serve as the objects of knowledge; according to the argument which proceeds from the "one in many," ideas will be proved to exist also in the case of negations; on the ground of our thinking what has already perished there will be ideas of things that have perished, for there still remains a certain representation of them.

But the most serious objection of all is this: what in the world do the ideas contribute to the things of sense, either to those that are imperishable or to those that arise and perish? For they are not the cause of any motion or change in them. On the contrary they help us not a whit toward the knowledge of things other than 
themselves (for they are not the substances of those things, else they would be present in them); nor do they explain their existence, not being present in the things that participate in them. . . .

But again things other than the ideas do not arise from them, at least in any of the usual meanings of that expression. To call the ideas 'patterns,' and to say that other things 'participate' in them, is to use words void of meaning, or to talk in poetical metaphor. For what is it that does the work with its eyes fixed upon the ideas as patterns? It is in truth quite possible that something should come into being like something else without being expressly patterned after it. For instance, whether or not Socrates actually existed a man might arise like Socrates; and it is plain this is equally possible had the existing Socrates been imperishable.

And there must be several patterns of the same thing, consequently several ideas. For example, in the case of man there will be a pattern "animal" and "biped" as well as the pattern "man as such."

Furthermore the ideas must be patterns not only of the things of sense, but also of the ideas themselves,-class, for example, as a class of ideas. And so the same thing will be at once pattern and image. Again it would seem to be impossible that the substance should exist apart from that of which it is the substance. How then if the ideas are the substances of things can they exist apart from them?

In the Phodo Plato speaks as if the ideas were the causes alike of existence and of coming into being. And yet even if we grant the existence of ideas, still the things that participate in them do not come into being unless there is some cause productive of movement. Besides, 
many other things come into being, such as a house or a ring, for which we do not assume the existence of ideas. This being the case it is clearly possible that other things also should be or come into being through causes like those operative in the cases just mentioned.

ARISTOTLE'S OWN VIEW REGARDING THE UNIVERSAL

That ${ }^{5}$ it is impossible to acquire knowledge through demonstration if we have no knowledge of primary principles immediately known we have shown above. One might, however, raise the question with regard to the knowledge of these immediate principles ... whether the habits of mind that give this knowledge, not being innate are developed in us, or whether they are innate but have escaped our notice. On the one hand it is absurd to say that we already have them, for then we should be saying that we have, all unknown to us, a knowledge more accurate than demonstration. If on the other hand we suppose that we have to begin with no such immediate principles, how should we ever know or learn them unless some knowledge had preceded? That would be impossible as we said above in treating of demonstration. The obvious inference is that it is impossible that we should already have this knowledge, and equally impossible that it should be developed in us if we are entirely ignorant and have no habits of mind [fitting us to detect them]. We must then have some such faculty, but not of such a kind as to be superior in point of accuracy to the principles themselves. And this faculty seems to be shared by all animals, for they all have an innate critical faculty called sense-perception.

- Arist. An. Post. II. 19. 99 b 20 
Without ${ }^{\circ}$ the universal it is impossible to have knowledge; but separating [the universal from the individual] was the cause of all the difficulties that attended the theory of ideas.

It 7 is not necessary that, if there is to be demonstrative truth, the ideas must exist, or some unity over and above the many individual things; but it is necessary that there should be some unity that may be truly predicated of the many things. Otherwise there will be no universal, and without the universal there would be no middle term, and hence no demonstration.

\section{$*^{*}$ *}

Unless 8 there were something over and above the individual things there would be no object of reason, but all things would be merely objects of sense, and consequently there would be no knowledge of anything, unless indeed one affirm that sense-perception is knowledge.

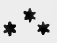

It ${ }^{9}$ is evident then that no universals exist over and above the individual objects and separate from them. And those who assume the reality of ideas are right in giving them such independent and separate existence in 80 far as they are substances; they are wrong, however, in calling the unity which is predicated of many individual things [such a substantial] idea. The cause of their confusion is the fact that they are unable to tell us what such imperishable substances are which exist over and above the individual objects of sense. And so they make them in form the same as the perishable

- Arist. Met. XII. 9, 1086 b 8.

- Arist. An. Post. I. 11, 77 a 5.

- Arist. Met. II. 4, 999 b 1.

- Arist. Met. VI. 16, 1040 b 27. Cf. Psych. III. 18, 432 a 4 . 
objects of sense (for these we know), and speak of man

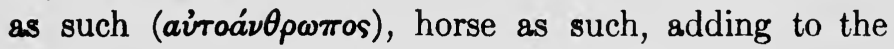
objects of sense the expression "as such."

It 10 is apparently impossible that any of the so-called universals should exist as substance.

Of 11 sensuous substances taken individually there is neither definition nor proof possible, because they possess matter, and the nature of matter is such that it is possible for it to be, and, also, not to be.

Substance ${ }^{12}$ is the indwelling form or idea, and the concrete substance consists of ideas in conjunction with matter. For example, take the idea "hollowness": this and the nose together give the snub nose or snubnosedness.

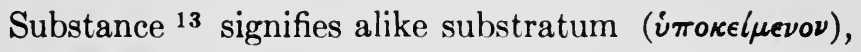
and the essential notion ( $\tau \dot{c} \tau \dot{\imath} \dot{\eta} \nu$ eiva $)$, and that which consists of both, and, also, the universal.

\section{THE FOUR CAUEES}

One ${ }^{14}$ meaning of the word cause is the matter from which anything comes into being. For example, bronze is the material cause of the statue. . . . A second meaning is, form and pattern. This is the same as the essential notion ( $\delta$ dóyos $\tau o \hat{v} \tau \ell \dot{\eta} \nu$ eival). . . . In the third place cause means the principle which produces change, or puts a stop to it. For example, one who gives advice

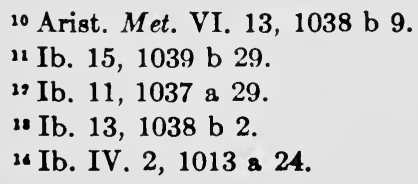


is cause in this sense, or the father is cause of the child; . . Finally, cause is used as meaning end or purpose, i. e., as that for the sake of which anything is done. For example, health is the final cause of taking a walk.

$$
*_{* ;}^{*}
$$

Since ${ }^{15}$ we find that there are several kinds of causes of natural processes . . . we must determine in regard to them which is naturally primary, and which secondary. The primary cause appears to be what we describe as that for the sake of which [a thing is done], for this gives

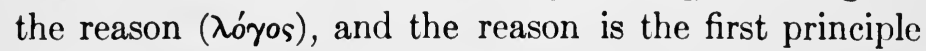
alike in the case of the things that are manufactured and in the case of the things that arise in the course of nature. For when by means of discursive reasoning or sense-perception a physician has determined for himself the nature of health, or the builder the nature of a house, they give the reasons and the causes of what they do in each individual case, and tell why it must be done thus and so.

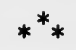

First ${ }^{16}$ and foremost, matter when strictly defined means the substratum which is the subject of generation and destruction.

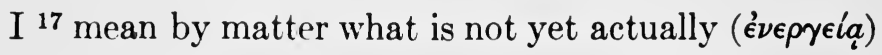
an individual object, but is such potentially ( $\delta v \nu a ́ \mu \epsilon \iota)$.

\section{$*^{*} *$}

I ${ }^{18}$ mean by matter as such neither a definite something nor a quantity nor anything else that can be described by the categories which define being.

16 Arist. De Part. An. I. 6, 39 b 11.

16 Ib. De Gen. et Cor. I. 4, 320 a 2.

${ }_{17}$ Ib. Met. VII. 1, 1042 a 27.

18 Ib. VI. 3, 1029 a 20. 
Matter ${ }^{19}$ is the contingent cause of that which occurs incidentally and over and above what regularly takes place.

\section{ARIETOTLE'S CONCEPTION OF GOD}

NECESSITY OF ASSUMING A FIRST CAUSE OR A PRIME MOVER

Since, ${ }^{20}$ as we have seen, substances are of three kinds, two belonging to the physical world, the third being immovable, we have now to speak of the last, and to show that of necessity there exists some eternal immovable substance.

Of things that exist substances are the first, and if they are all perishable then everything is perishable. But it is impossible that there should be either beginning or end of motion: it is forevermore. And the same is true of time, for it is impossible that there should be either a "before" or an "after" if there is no time. Motion is then unceasing, just as time is, for time is either identical with motion or else it is a certain property of motion. And there is no motion save in space, no unceasing motion save motion in a circle. If, however, there were something merely possessing the power to create and to impart motion, but not actually operative, still there is no motion. For it is conceivable that that which possesses potentiality should not be actually operative. Nor are we any better off if we assume eternal substances, like the "ideas" which some have assumed, unless they contain some principle that is capable of bringing about change. And even this would not be sufficient, nor would some other substance over and above the ideas accomplish the purpose; for unless this principle be actually operative there will be no motion. Moreover,

19 Arist. Met. V. 2, 1027 a 14.

20 Ib. XI. Ch. 6. 
even if it be actually operative, but if at the same time its substance be but potentiality, it will not suffice; for still there will be no eternal motion, for it is conceivable that what potentially is should not come into being. It is necessary therefore that there should be a principle of such a nature that its very substance is its being actually operative. Further, substances of this sort must be immaterial; for they must be eternal, if anything at all is eternal. They must therefore be pure actuality.

But here arises a difficulty: It is commonly supposed that everything actual is also potential while not everything potential is actual, from which it would follow that what potentially is is prior to what actually is. But if this were so not a single thing would truly exist; for it is possible that a thing should have the capacity to exist and at the same time not yet truly exist. To be sure, if we accept the view of the theologians that all things sprang from Night, or that of the physical philosophers that all things were originally mixed together, we have to face the same impossibility. For how will the motion get started if there is to be no cause that is actually realized? Matter will not put itself in motion. It is, say, the builder's art that does this.-So, too, menses and earth must be set in motion by semen and seeds.-This is the reason some philosophers, like Leucippus and Plato, assume an eternal actuality; for they say that motion is eternal. But they do not tell us why; nor do they tell us what the motion is, nor how it takes place in each case, nor what causes it. The truth is, nothing is set in motion by chance; there must have been always some underlying cause, just as is the case now; a thing is moved this way by its nature, that way by force-whether of the mind or of something else. 
Furthermore, of what sort is the primal motion? It makes a vast deal of difference how we answer this question. But Plato himself is not entitled to say that the principle of movement is what he sometimes assumes it to be, the self-mover, for he says that the soul is both subsequent to, and at the same time coeval with, the heavens.

To suppose that what is potential is prior to what is actual is partly right and partly wrong. How this is so we have explained above. That actuality is prior to potentiality is the view of Anaxagoras, for "mind" is actual, and of Empedocles, too, with his doctrine of Love and Hate, and of all those who, with Leucippus, affirm that motion is eternal. If it is true that actuality is prior to potentiality it follows that we must not suppose that Chaos and Night existed for an indefinite time, but rather that the same things that exist now existed always, moving like a circle returning upon itself, or in some other way. Now if the same world exists always in the circular process there must be something that always abides and that is actually operative in one and the same way. But the process of coming into being and passing away is possible only on the assumption that there is something else that exists always and exerts its activity now in this way and now in that; and so it must exert its activity in one way with reference to itself, in another way with reference to something other than itself. It must therefore exert its activity either with reference to the primal heavens [the heaven of the fixed stars] or with reference to another and a different principle. Now it must of necessity be with reference to the primal heavens, for that in turn is cause both of its own movement and of the movement of the lower heavens [i. e., the planetary 
region, the sun, etc.]. And so the heaven of the fixed stars is superior, for it is the cause of the eternally uniform motion while the lower heaven is cause of the diversity of motion. Evidently both are causes of the eternally diverse motion. And in this way too the different kinds of motion are related to each other. What need therefore to seek for other principles?

\section{DIVINE REASON AS THE PRIME MOVER}

Since ${ }^{21}$ the case stands thus-and if it did not stand thus all things would have to spring from Night, or from Chaos, or from the non-existent-our difficulties would appear to be solved. There exists [1] something always moving with ceaseless motion, and its motion is cyclical. This is shown too not merely by our argument but also by the actual fact. Consequently the primal heavens are everlasting. Furthermore there exists [2] that to which these impart motion. And since that which both imparts motion and has motion imparted to it is in the mean position there exists also [3] something which imparts motion without itself having motion imparted to it-something which is eternal, which is an individual substance and wholly actual. And this is the way it imparts motion. It is like the object of desire, or the object of thought, for these impart motion without being themselves moved. Fundamentally the object of desire and the object of thought are the same. The object of desire is that which appears beautiful; the object of the will is primarily that which $i$ s beautiful. It is not the striving that makes a thing seem good; rather we strive after a thing because it seems good. It is the thought that comes first. And the mind moves under ${ }^{21}$ Arist. Met. XI. Ch. 7. 
the instigation of the object of thought. But only the positive series is in itself the thought series, and in this series substance stands first, and substance that is pure and simple and fully actual is first of all. (We must not confound the simple with the one. The "one" signifies quantity, the "simple" a kind of relation.) But surely the beautiful and that which is desirable on its own account belong in the same positive series, and here the best, or its likeness, stands first. And that the final cause belongs to the immovable order the method of division makes plain; for purpose is always a purpose which some subject has, and of these the one-the purpose itself-is immovable, while the other-the purpose in its relation to a subject-is not. And [this immovable final cause] draws its object unto itself as the beloved the lover; and that which is thus set in motion imparts motion to all other things.

Now if anything is subject to motion it is possible for it to be different from what it is. Consequently if the primal actuality is the motion of the heavens, in so far as it is in motion it is possible for it to be different from what it is-different in position if not in substance. Since, however, there is something that imparts motion, being itself not subject to motion but existing in pure actuality, it is impossible that $i t$ should be in any respect different from what it is. The first of all changes is motion in space, and, in fact, circular motion. And the prime mover imparts this motion, and is therefore necessarily existent, and in so far as necessarily existent, nobly existent, and thus the first principle of all. (Necessity is a term used in several senses: (1) necessity by force, as contrary to natural impulse; (2) the necessity of that without which the good is not; and (3) the 
necessity of that which cannot be otherwise, but which absolutely is.) Upon such a principle then heaven and nature depend.

God's life is like that of which we catch a transient glimpse when our life is at its best. Thus indeed his life always is (a thing which is impossible for us), for his very self-activity is bliss. And that is why we find greatest pleasure in being awake, in feeling and in thinking, and in the hopes and memories that come through these activities. But thinking, pure thinking, has for its object that which is in itself the best, and such thinking when most perfect has for its object the supreme good. The intellect thinks itself in grasping the intelligible, for it becomes intelligible in laying hold upon and thinking its object. Therefore, the intellect and the intelligible are the same thing; for to be able to receive the intelligible and the real is what we mean by intellect, and the intellect actually lives in doing this. And it is this actual life of the intellect, rather than the intelligible as object, that seems to be the divine element in the intellect, and pure speculative vision is what is best and most enjoyable. If then God is always as well off as we are now and then, how wonderful it is! And if he is always better off, it is still more wonderful. But such is the fact. And life belongs to him; for the activity of the mind is life, and he is that activity. Pure self-activity of reason is God's most blessed and everlasting life. We say that God is living, eternal, perfect; and continuous and everlasting life is God's, for God is eternal life.

And they are wrong who, like Pythagoras and Speusippus. hold that the most beautiful and the best are not found in the first cause, arguing from the fact that whit 
the first cause produces plants and animals, still it is from these that the perfect plant or animal springs. For the seed comes from a complete plant previously existing; the seed is not first, but the complete plant. Just as we should say that man is prior to the germnot the man who springs from it, but he from whom it comes.

That there is then a substance which is eternal and immovable and separable from the objects of sense is evident from what has been said. And it has also been shown that this substance cannot have extension but is without parts and indivisible. For it imparts motion through endless time, and nothing limited has unlimited potentiality. Now since every magnitude is either limited or unlimited, for the reason given God cannot have limited magnitude; nor yet can he have unlimited magnitude because, in a word, there is no such magnitude.

And further that God is free from passion and from qualitative change has also been shown, for all other changes are subsequent to motion in space. Why these things are so is now clear.

DIVINE REASON AND ITS OBJECT

With ${ }^{22}$ regard to the divine reason certain problems arise. For while it passes for the divinest of manifestations still what its nature must be in order that it should be such is a question hard to answer. For if it thinks of nothing wherein would lie its majesty? It were just like a man asleep. On the other hand if it thinks of something and that something, being different from itself, controls its thinking, it cannot be the noblest substance-

${ }^{22}$ Arist. Met. XI. Ch. 9 


\section{SOURCE BOOK IN ANCIENT PHILOSOPHY}

for in that case that which is its substance is not thinking but potentiality. And it is through actual thinking that it gets its noble character.

Further, whether its substance be reason or thinking, what does it think about? Clearly, either itself or something else; and if something else, either always the same thing, or now one thing and now another. Does it forsooth make no difference whether it thinks about what is excellent or whether it simply thinks at random? Is it not indeed absurd that it should be thinking discursively about a plurality of things? It is evident therefore that it thinks about what is most divine and most noble, and that it changes not, for it could change only for the worse, and any motion would be already such a change.

Now in the first place if the divine reason is not actual but only potential thinking, it is conceivable that it should find its everlastingness but toil and weariness. And in the second place it is evident that then something else would be nobler than reason, namely, the object of reason. For thinking, and the activity of thinking, would belong also to that which thinks the most ignoble thoughts. And consequently, if this is to be avoidedand there are some things which it is better not to see than to see-then thinking as such would not be the best thing.

The divine reason then, if it is the supremely excellent thing, has itself for its object, and its thinking is a thinking of thinking. But science, perception, opinion, discursive reasoning, seem always to have something other than themselves for their object and only incidentally to be their own object.

Again, if there is a difference between thinking and 
being thought, by which of the two does reason get its nobility? For [in the case supposed] thinking and being thought are in essence not the same. However, in some cases knowledge is its own object. In the case of the creative sciences it is the immaterial substance and the essential notion that is the object of knowledge; in the case of the speculative sciences it is reason itself and thinking. Since, then, the mind is not one thing and the object of the mind another, in cases where matter is not involved, the two must be identical, and thinking is one with its object.

Still a puzzle remains if the object of thought is composite, for then there might be change from part to part within the whole. But the fact is everything immaterial is indivisible. And just as the human mind, which has for its object composite things, is related to its object in favored moments-for it does not then grasp the good in this or that part of its object, but rather the best in the whole of it, the object in this case being something different from itself-just so the divine thinking is itself relased to itself through all eternity. 


\section{XV \\ ARISTOTLE ON PSYCHOLOGY}

THE NATURE OF THE SOUL

$\mathrm{WE}^{1}$ will now . . . . attempt to determine what soul is, and what is the most comprehensive definition that can be given of it.

Real substance is the name which we assign one class of existing things; and this real substance may be viewed from several aspects, either, first, as matter, meaning by matter that which in itself is not any individual thing; or, secondly, as form and specific characteristic in virtue of which an object comes to be described as such and such an individual; or, thirdly, as the result produced by a combination of this matter and this form. Further, while matter is merely potential existence, the form is perfect realization (a conception which may be taken in two forms, either as resembling knowledge possessed or as corresponding to observation in active exercise).

These real substances again are thought to correspond for the most part with bodies, and more particularly with natural bodies, because these latter are the source from which other bodies are formed. Now among such natural bodies, some have, others do not have life, meaning here by life the process of nutrition, increase, and decay from an internal principle. Thus every natural

${ }^{1}$ Arist. De An. II. 1, 412 a 4 . The passages from Aristotle s Psychology which follow are all taken from Wallace's translation 
body possessed of life would be a real substance, and a substance which we may describe as composite.

Since then the body, as possessed of life, is of this compound character, the body itself would not constitute the soul: for body is not [like life and soul] something attributed to a subject; it rather acts as the underlying subject and the material basis. Thus then the soul must necessarily be a real substance, as the form which determines a natural body possessed potentially of life. The reality, however, of an object is contained in its perfect realization. Soul therefore will be a perfect realization of a body such as has been described. Perfect realization, however, is a word used in two senses: it may be understood either as an implicit state corresponding to knowledge as possessed, or as an explicitly exercised process corresponding to active observation. Here, in reference to soul, it must evidently be understood in the former of these two senses: for the soul is present with us as much while we are asleep as while we are awake; and while waking resembles active observation, sleep resembles the implicit though not exercised possession of knowledge. Now in reference to the same subject, it is the implicit knowledge of scientific principles which stands prior. Soul therefore is the earlier or implicit perfect realization of a natural body possessed potentially of life.

Such potential life belongs to everything which is possessed of organs. Organs, however, we must remember, is a name that applies also to the parts of plants, except that they are altogether uncompounded. Thus the leaf is the protection of the pericarp and the pericarp of the fruit; while the roots are analogous to the mouth in animals, both being used to absorb nourishment. Thus 


\section{SOURCE BOOK IN ANCIENT PHILOSOPHY}

then, if we be required to frame some one common definition, which will apply to every form of soul, it would be that soul is the earlier perfect realization of a natural organic body.

The definition we have just given should make it evident that we must no more ask whether the soul and the bodly are one, than ask whether the wax and the figure impressed upon it are one, or generally inquire whether the material and that of which it is the material are one; for though unity and being are used in a variety of senses, their most distinctive sense is that of perfect realization.

A general account has thus been given of the nature of the soul: it is, we have seen, a real substance which expresses an idea. Such a substance is the manifestation of the inner meaning of such and such a body. Suppose, for example, that an instrument such as an axe were a natural body; then its axehood or its being an axe would constitute its essential nature or reality, and thus, so to speak, its soul; because were this axehood taken away from it, it would be no longer an axe, except in so far as it might still be called by this same name. The object in question, however, is as matter of fact only an axe; soul being not the idea and the manifestation of the meaning of a body of this kind, but of a natural body possessing within itself a cause of movement and of rest.

The theory just stated should be viewed also in reference to the separate bodily parts. If, for example, the eye were possessed of life, vision would be its soul: because vision is the reality which expresses the idea of the eye. The eye itself, on the other hand, is merely the material substratum for vision: and when this power of vision fails, it no longer remains an eye, except in so 
far as it is still called by the same name, just in the same way as an eye carved in stone or delineated in painting is also so described. Now what holds good of the part must be applied to the living body taken as a whole: for perception as a whole stands to the whole sensitive body, as such, in the same ratio as the particular exercise of sense stands to a single organ of sense.

The part of our definition which speaks of something as "potentially possessed of life" must be taken to mean not that which has thrown off its soul, but rather that which has it: the seed and the fruit is such and such a body potentially. In the same way then as cutting is the full realization of an axe, or actual sceing the realization of the eye, so also waking may be said to be the full realization of the body; but it is in the sense in which vision is not only the exercise but also the implicit capacity of the eye that soul is the true realization of the body. The body on the other hand is merely the material to which soul gives reality; and just as the eye is both the pupil and its vision, so also the living animal is at once the soul and body in connection.

It is not then difficult to see that soul or certain parts of it (if it naturally admit of partition) cannot be separated from the borly: for in some cases the soul is the realization of the parts of body themselves. It is, however, perfectly conceivable that there may be some parts of it which are separable, and this because they are not the expression or realization of any particular body. And indeed it is further matter of doubt whether soul as the perfect realization of the body may not stand to it in the same separable relation as a sailor to his boat.

This much may suffice as a description and sketch of the nature of the soul. 


\section{TEE ANIMATE AND THE INANIMATE}

It ${ }^{2}$ may serve as a fresh beginning for our inquiry to say that the animate is distinguished from the inanimate or soulless by the fact of life. There are a number of ways in which a thing is said to live; yet should it possess only one of them-as, for example, reason, sense-perception, local movement and rest, and further movement in respect of nutrition as well as of decay and growthwe say it lives. Hence it is that all plants are thought to live; because they manifestly contain within themselves such a power and principle as enables them to acquire growth and undergo decay in opposite directions; for they do not while growing upwards not grow downwards, but they grow in both directions and on all sides, and they continue to live so long as they can assimilate nourishment. Now this faculty of nutrition may be separated from the other functions; but in the case of mortal creatures the other faculties cannot exist apart from this, as indeed is evident from plants which possess no other psychic power except this faculty of growth.

It is then through this principle of nutrition that life is an attribute of all living things. At the same time the animal strictly so called only begins when we reach sensation; for even those objects which do not move themselves nor change their position but possess sensation are said to be animals and not merely to be living. Among the senses themselves, it is touch which is the fundamental attribute of all animal forms. And just as the nutritive function may exist apart from touch and every form of sense, so also may touch exist without any of the other senses. Thus while nutritive is the name given

Arist. De An. II. 2, 413 a 20. 
to that part of the soul in which plants share as well as animals, all animals are found to possess the sense of touch.

\section{$*^{*} *$}

[Life, ${ }^{3}$ then, and sensation are what mark the animate.] But there are two ways in which we may speak of that by which we live and have sensation, just as also that by which we know may be employed to denote either knowledge or the mind, by both of which we are in the habit of speaking of people as knowing. So also that by which we are in health denotes on the one hand the health itself, on the other hand some portion of the body, or it may be the whole of it. Now of these two uses, knowledge and health are what we may term the determining form and notion and so to speak the realization of the recipient faculty, in the one case of knowledge, in the other of health-for the passive material which is subject to modification is what is taken to be the home of the manifestation of the active forces. Soul then is the original and fundamental ground of all our life, of our sensation and of our reasoning. It follows therefore that the soul must be regarded as a sort of form and idea, rather than as matter and as underlying subject. For the term real substance is, as we have before remarked, employed in three senses: it may denote either the specific form, or the material substratum, or thirdly the combination of the two: and of these different aspects of reality the matter or substratum is but the potential ground, whereas the form is the perfect realization. Since then it is the product of the two that is animate, it cannot be that the body is the full realization or expression of the soul; rather on the contrary it is the soul which is the full realization of some body.

Arist. De An. II. 2, 414 a. 
NOURISHMENT THE FUNDAMENTAL FUNCTION; TOUCH THE FUNDAMENTAL SENGE

Of 4 the powers of soul which have been mentioned, some organisms, as has been said, possess all, others again a few, while a third class possesses one only. The powers in question are those of nutrition, of sensation, of desire, of local movement, and of reasoning. Plants possess the function of nutrition only: other creatures have this and also the faculty of sensation; and if this latter, then they must also have the faculty of desire: for desire includes appetite and passion and wish. Animals, however, without exception possess one at least among the senses-viz., touch: and wherever a faculty of sense is present it is accompanied by a feeling of pleasure and pain, and an object which is pleasant or painful. But where these are present, there appetite is also: for appetite is the desire of what is pleasant.

Besides, all animals have a sense for nourishmentviz., touch-for it is by means of things dry and moist, hot and cold, that all animals are fed: and touch is the sense which directly perceives these.

\section{THE HIGHER FACULTIES PRESUPPOSE THE LOWER}

So ${ }^{5}$ likewise animals possessed of the faculties of sense sometimes have, somctimes do not have, the faculty of local movement; while finally the smallest class possess also reflection and understanding. And all mortals that possess the faculty of reasoning possess also all the other powers, whereas those that possess each of those others do not in every case possess reflection; some in fact do not even possess imagination while others live by the

- Arist. De An. II. 3, 414 a.

- Ib. II. 3,415 a. 
aid of this alone. As regards the speculative reason a different account must be given. Meanwhile it is clear that the special definition of each of these powers separately is at the same time the most appropriate account of the soul.

\section{BENSE-PERCEPTION}

The ${ }^{6}$ general character of sense in all its forms is to be found in seeing that sense-perception is that which is receptive of the forms of things sensible without their matter, just in the same way as wax receives the impress of the seal without the iron or the gold of which it is composed, and takes the figure of the gold or bronze, but at the same time not as bronze or gold.

Similarly, sense receives the impress of each object that possesses color, or flavor, or sound, not, however, in so far as each of them is such and such a definite individual, but rather so far as it is of such and such a general character, and relatively to its notion. An organ of sense-perception then is reached so soon as any part displays this power of apprehending the general character of objects. And thus the organ and the faculty of sense are essentially and fundamentally the same, although they manifest themselves in different ways; otherwise, in fact, the faculty perceiving would be as it were a sort of magnitude: whereas neither the essential character of perception nor the faculty of sense can be described as a magnitude-rather it is a power to read the essential notion of the object.

These considerations show why sentient impressions in excess destroy the organ of sense. The reason is that if the movement of the organ of sense be too strong, the

- Arist. De An. II. 12, 424 a. 
relation, which, as we have seen, sense involves, is broken much in the same manner as harmony and tone become discordant when the strings are violently struck. The same fact explains also why plants possess no senseperception although they have a psychic element and are impressed in some degree by things tangible, becoming, as they do, both hot and cold. The reason is that they do not possess that faculty (which sense implies) of acting as a mean between extremes, and have no fundamental capacity for receiving the form only of the things of sense: but that, on the contrary, at the same time as they receive the form of anything, they receive the matter likewise.

\section{COGNITION}

$\mathrm{We}^{7}$ must next discuss the cognitive and thinking part of soul, whether it be separated from our other mental faculties or whether it is not separated physically, but be so only by thought and abstraction, and inquire what is the specific character of thought, and how it is that at some stage or another thought begins to operate.

Thinking, we may assume, is like perception, and, if so, consists in being affected by the object of thought or in something else of this nature. Like sense then, thought or reason must be not entirely passive, but receptive of the form-that is, it must be potentially like this form, but not actually identical with it: it will stand, in fact, toward its objects in the same relation as that in which the faculty of sense stands toward the objects of perception. Reason therefore, since it thinks everything, must be free from all admixture, in order that, to use the phrase of Anaxagoras, it may rule the 'Arist. De An. III. 4, 429 a 10. 
world - that is, acquire knowledge: for the adjacent light of any foreign body obstructs it and eclipses it. Its very nature, then, is nothing but just this comprehensive potentiality: and the reason-that is, that function through which the soul is ratiocinative and frames notions-is therefore, previously to the exercise of thought, actually identical with nothing which exists.

This consideration shows how improbable it is that reason should be incorporated with the bodily organism: for if so, it would be of some definite character, either hot or cold, or it would have some organ for its operation, just as is the case with sense. But, as matter of fact, reason has nothing of this character. There is truth, too, in the view of those who say the soul is the source of general ideas: only it is soul not as a whole, but in its faculty of reason: and the forms or ideas in question exist within the mind, not as endowments which we already possess, but only as capacities to be developed.

The difference, however, between the impassivity of the faculty of reason and of the faculty of sense is clear from a consideration of the organs and the processes of sense-perception. Sense, for example, is unable to acquire perception from an object which is in too great excess-cannot, to take an instance, perceive sound from extremely loud noises, nor see nor smell anything from too violent colors and odors. Reason, on the contrary, when it applies itself to something extremely intellectual, does not lessen but rather increases its power of thinking inferior objects, the explanation being that the faculty of sense is not independent of the body, whereas reason is separated from it. And since reason becomes each of its objects in the sense in which he who is in actual possession of knowledge is described as 
knowing - this resulting when he can apply his knowledge by himself - the reason as a developed capacity is similar to what it was previously as a mere unformed faculty, though not the same as what it was before it learned or discovered: and it may in this final stage be said to think itself.

\section{Creative Reason}

The ${ }^{8}$ same differences, however, as are found in nature as a whole must be characteristic also of the soul. Now in nature there is on the one hand that which acts as material substratum to each class of objects, this being that which is potentially all of them; on the other hand, there is the element which is causal and creative in virtue of its producing all things, and which stands toward the other in the same relation as that in which art stands toward the materials on which it operates. Thus reason is, on the one hand, of such a character as to become all things, on the other hand of such a nature as to create all things, acting then much in the same way as some positive quality, such as for instance light: for light also in a way creates actual out of potential color.

This phase of reason is separate from and uncompounded with material conditions, and, being in its essential character fully and actually realized, it is not subject to impressions from without: for the creative is in every case more honorable than the passive, just as the originating principle is superior to the matter which it forms. And thus, though knowledge as an actually realized condition is identical with its object, this knowledge as a potential capacity is in time prior in the individual, though in universal existence it is not even in time thus prior to actual thought. Further, - Arist. De An. III. 5, 430 a 10. 
this creative reason does not at one time think, at another time not think [it thinks eternally]; and when separated from the body it remains nothing but what it essentially is; and thus it is alone immortal and eternal. Of this unceasing work of thought, however, we retain no memory, because this reason is unaffected by its objects; whereas the receptive passive intellect (which is affected) is perishable, and can really think nothing without the support of the creative intellect.

\section{REASON AND JUDGMENT}

With ${ }^{9}$ regard then to the exercise of reason, the thinking of isolated single terms falls within a sphere in which there is no falsity: when, on the other hand, we find both falsity and truth, there we reach a certain combination of ideas as constituting one conception; much in the same way as Empedocles said: "Thereupon many there were whose heads grew up neckless entirely," but were afterward brought together by friendship. In a corresponding fashion is it that those notions which are originally separate are afterwards connected, as is, for instance, the case with the two notions incommensurate and diagonal. Should the notions in question be, however, related to the past or to the future, thought then adds on the idea of time to that of mere connection. Falsehood, in fact, always involves combination and connection: even in asserting the white to be not white we bring not-white into a combination. It should be added, at the same time, that all this process might be described, not as combination, buic rather as disjunction or division. Anyhow it follows that truth or falsehood is not limited to saying that "Cleon is white," but in-

-Arist. De An. III. 6, 430 a 26. 
cludes the judgment that he was or will be: and the process of thus reducing our ideas into the unity of a single judgment is in each case the work of reason.

\section{REASON AND ITS OBJECTS}

We ${ }^{10}$ will now sum up the conclusions we have made about the soul. The soul, we have seen, is in a way all existing things. For the objects of existence are either objects of sense or objects of thought; and while science is in a way identical with the objects of thought, sense again is one with the objects of sense. How this comes about is a point we must investigate.

Scientific thought and sense-perception thus spread themselves over objects, potential sense and science relating to things potential, actual to things actual. Now the sensitive and the scientific faculty in the soul are potentially these objects-that is to say, the objects of scientific thought on the one hand, the objects of sense on the other. It must be then either the things themselves or their forms with which they are identical. The things themselves, however, they are not: it is not the stone, but simply the form of the stone, that is in the soul. The soul, therefore, is like the hand: for just as the hand is the instrument through which we grasp other instruments, so also reason is the form through which we apprehend other forms, while sense-perception is the form of the objects of sense.

[The forms of reason are not, however, something different from the things of sense.] As there is, according to the common opinion, no object outside the magnitudes of sense, it follows that the ideas of reason are contained in the forms of sense, both the so-called ${ }^{10}$ Arist. De An. III. 8, 431 b 20. 
abstract conceptions and the various qualities and attributes that determine sensible phenomena. And further, without the aid of sense-perception we never come to learn or understand anything; and whenever we consider something in the mind, we must at the same time contemplate some picture of the imagination: for the pictures of the imagination correspond to the impressions of the senses, except that the former are without material embodiment.

At the same time imagination is something different from affirmation and negation, for it is only by a combination of ideas that we attain to truth and falsehood. But, it may be asked, in what respect will our primary ideas differ from mere images of sense? And to this, perhaps, we may reply that they are, as little as other ideas which we frame, mere images of sense, although never framed without the help of such representative images.

THE SPRINGS OF ACTION

There ${ }^{11}$ are, however, at least two faculties which are manifestly motive-viz., desire or reason, if we regard imagination as a form of reason. Frequently, in fact, it is the pictures of imagination as against knowledge that people follow, and among animals other than man it is not thought nor ratiocination, but simply this power of representing images of sense, which guides them. Both then reason and desire are fitted to produce and lead to local movement. The reason which is here intended is that which calculates for some purpose-that is, it is the practical reason, distinguished from the speculative by its end. As for desire, it is always directed to some object: in fact, it is the object at which desire ${ }^{11}$ Arist. De An. III. 10, 433 a 11. 
aims that forms the starting-point of the practical reason, although it is some particular detail which forms the beginning of the action.

It is then on good grounds that people have viewed as springs of action these two faculties of desire and practical intellect; for the faculty of desire has itself a motive force, and the intellect excites to action just in so far as the object of desire supplies it with a startingpoint; just as, similarly, imagination when it moves to action does not do so independently of desire.

The spring of action thus resolves itself into one single thing, viz., the object of desire. For if there were two faculties acting as springs to action-reason on the one hand, desire on the other-they would have to move in virtue of some common character they shared. Now reason, it is found, does not act as a spring of action independently of desire: for settled wish is a form of desire, and when a man is led to act according to his reasonable conviction he is moved also in a manner corresponding to his wish. Desire, however, excites to action contrarily to reason, appetite, which so acts, being one of the forms of desire. And thus, then, it would seem, reason is always true and right, whereas desire and imagination may be both right and not right.

It is then always the object of desire that moves to action; and this is either the good or the apparent goodnot good, however, as a whole, but simply that form of it which relates to action-that is, which is contingent and admits of being other than it is. 


\section{XVI}

\section{ARISTOTIE ON ETHICS}

THE SUMMUM BONUM

EvERY ${ }^{1}$ art and every kind of inquiry, and likewise every act and purpose, seems to aim at some good; and so it has been well said that the good is that at which everything aims. ... .

If then in what we do there be some end which we wish for on its own account, choosing all the others as means to this, but not every end without exception as a means to something else (for so we should go on ad infinitum, and desire would be left void and objectless), this evidently will be the good or the best of all things.

And surely from a practical point of view it much concerns us to know this good; for then, like archers shooting at a definite mark, we shall be more likely to attain what we want. . .

We see that there are many ends. But some of these are chosen only as means, as wealth, flutes, and the whole class of instruments. And so it is plain that not all ends are final.

But the best of all things must, we conceive, be something final.

If then there be only one final end, this will be what we are seeking-or if there be more than one, then the most final of them.

${ }^{1}$ Arist. Ethics, I. 1, 1. The passages in this section are taken from Peters's translation of Aristotle's Nichomachean Ethics. 
Now that which is pursued as an end in itself is more final than that which is pursued as means to something else, and that which is never chosen as means than that which is chosen both as an end in itself and as means, and that is strictly final which is always chosen as an end in itself and never as means.

Happiness seems more than anything else to answer to this description: for we always choose it for itself, and never for the sake of something else; while honor and pleasure and reason, and all virtue or excellence, we choose partly indeed for themselves (for, apart from any result, we should choose each of them), but partly also for the sake of happiness, supposing that they will help to make us happy. But no one chooses happiness for the sake of these things, or as a means to anything else at all.

We seem to be led to the same conclusion when we start from the notion of self-sufficiency.

The final good is thought to be self-sufficing (or allsufficing). In applying this term we do not regard a man as an individual leading a solitary life, but we also take account of parents, children, wife, and, in short, friends and fellow-citizens generally, since man is naturally a social being. Some limit must indeed be set to this; for if you go on to parents and descendants and friends of friends, you will never come to a stop. But this we will consider further on: for the present we will take self-sufficing to mean what by itself makes life desirable and in want of nothing. And happiness is believed to answer to this description.

And further, happiness is believed to be the most desirable thing in the world, and that not merely as one among other good things; if it were merely one among 
other good things [so that other things could be added to it], it is plain that the addition of the least of other goods must make it more desirable: for the addition becomes a surplus of good, and of two goods the greater is always more desirable.

Thus it seems that happiness is something final and self-sufficing, and is the end of all that man does.

But perhaps the reader thinks that though no one will dispute the statement that happiness is the best thing in the world, yet a still more precise definition of it is needed.

TO FIND IT WE ASK, WHAT IS MAN'S FUNCTION?

This will best be gained, I think, by asking, What is the function of man? For as the goodness and the excellence of a piper or a sculptor, or the practiser of any art, and generally of those who have any function or business to do, lies in that function, so man's good would seem to lie in his function, if he has one.

But can we suppose that, while a carpenter, or a cobbler has a function and a business of his own, man has no business and no function assigned him by nature? Nay, surely as his several members, eye and hand and foot, plainly have each its own function, so we must suppose that man also has some function over and above all these.

What then is it?

Life evidently he has in common even with the plants, but we want that which is peculiar to him. We must exclude, therefore, the life of mere nutrition and growth.

Next to this comes the life of sense; but this too he plainly shares with horses and cattle and all kinds of animals. 


\section{SOURCE BOOK IN ANCIENT PHILOSOPHY}

There remains then the life whereby he acts-the life of his rational nature, with its two sides or divisions, one rational as obeying reason, the other rational as having and exercising reason.

But as this expression is ambiguous, we must be understood to mean thereby the life that consists in the exercise of the faculties; for this seems to be more properly entitled to the name.

The function of man, then, is exercise of his vital faculties [or soul] on one side in obedience to reason, and on the other side with reason.

But what is called the function of a man of any profession and the function of a man who is good in that profession are generically the same, e.g., of a harper and of a good harper; and this holds in all cases without exception, only that in the case of the latter his superior excellence at his work is added; for we say a harper's function is to harp, and a good harper's to harp well.

Man's function then being, as we say, a kind of lifethat is to say, exercise of his faculties and action of various kinds with reason-the good man's function is to do this well and beautifully [or nobly].

But the function of anything is done well when it is done in accordance with the proper excellence of that thing.

Putting all this together, then, we find that the good of man is exercise of his faculties in accordance with excellence or virtue, or, if there be more than one, in accordance with the best and most complete virtue.

But there must also be a full term of years for this exercise; for one swallow or one fine day does not make a spring, nor does one day or any small space of time make a blessed or happy man. . . . 
But I think we may say that it makes no small difference whether the good be conceived as the mere possession of something, or as its use-as a rrere habit or trained faculty, or as the exercise of that faculty. For the habit or faculty may be present, and yet issue in no good result, as when a man is asleep, or in any other way hindered from his function; but with its exercise this is not possible, for it must show triself in acts and in good acts. And as at the Olympic games it is not the fairest and strongest who receive the crown, but those who contend (for among these are the victors), so in life, too, the winners are those who not only have all the excellences, but manifest these in deed.

And, further, the life of these men is in itself pleasant. For pleasure is an affection of the soul, and each man takes pleasure in that which he is said to love-he who loves horses in horses, he who loves sight-seeing in sight-seeing, and in the same way he who loves justice in acts of justice, and generally the lover of excellence or virtue in virtuous acts or the manifestation of excellence.

And while with most men there is a perpetual conflict between the several things in which they find pleasure, since these are not naturally pleasant, those who love what is noble take pleasure in that which is naturally pleasant. For the manifestations of excellence are naturally pleasant, so that they are both pleasant to them and pleasant in themselves.

Their life, then, does not need pleasure to be added to it as an appendage, but contains pleasure in itself.

Indeed, in addition to what we have said, a man is not good at all unless he takes pleasure in noble deeds. 
No one would call a man just who did not take pleasure in doing justice, nor generous who took no pleasure in acts of generosity, and so on.

If this be so, the manifestations of excellence will be pleasant in themselves. But they are also both good and noble, and that in the highest degree-at least, if the good man's judgment about them is right, for this is his judgment.

Happiness, then, is at once the best and noblest and pleasantest thing in the world, and these are not separated, as the Delian inscription would have them to be:

What is most just is noblest, health is best,

Pleasantest is to get your heart's desire.

For all these characteristics are united in the best exercises of our faculties; and these, or some one of them that is better than all the others, we identify with happiness.

But nevertheless happiness plainly requires external goods, too, as we said; for it is impossible, or at least not easy, to act nobly without some furniture of fortune. There are many things that can only be done through instruments, so to speak, such as friends and wealth and political influence: and there are some things whose absence takes the bloom off our happiness, as good birth, the blessing of children, personal beauty; for a man is not very likely to be happy if he is very ugly in person, or of low birth, or alone in the world, or childless, and perhaps still less if he has worthless children or friends, or has lost good ones that he had.

As we said, then, happiness seems to stand in need of this kind of prosperity. 
HOW VIRTUE IS ACQUIRED

Excellence, ${ }^{2}$ then, being of these two kinds, intellectual and moral, intellectual owes its birth and growth mainly to instruction, and so requires time and experience, while moral excellence is the result of habit or custom $(\tilde{\epsilon} \theta o s)$, and has accordingly in our language received a name formed by a slight change from $\ddot{\epsilon} \theta$ os.

From this it is plain that none of the moral excellences or virtues is implanted in us by nature; for that which is by nature cannot be altered by training. For instance, a stone naturally tends to fall downward, and you could not train it to rise upward, though you tried to do so by throwing it up ten thousand times, nor could you train fire to move downward, nor accustom anything which naturally behaves in one way to behave in any other way.

The virtues, then, come neither by nature nor against nature, but nature gives the capacity for acquiring them, and this is developed by training. . . .

But the virtues we acquire by doing the acts, as is the case with the arts too. We learn an art by doing that which we wish to do when we have learned it; we become builders by building, and harpers by harping. And so by doing just acts we become just, and by doing acts of temperance and courage we become temperate and courageous. ...

But habits or types of character are not only produced and preserved and destroyed by the same occasions and the same means, but they will also manifest themselves in the same circumstances. This is the case with palpable things like strength. Strength is produced by taking plenty of nourishment and doing plenty of hard work, and the strong man, in turn, has the greatest

2Arist. Ethics, II. 1, 1 
capacity for these. And the case is the same with the virtues: by abstaining from pleasure we become temperate, and when we have become temperate we are best able to abstain. And so with courage: by habituating ourselves to despise danger, and to face it, we become courageous; and when we have become courageous, we are best able to face danger.

The pleasure or pain that accompanies the acts must be taken as a test of the formed habit or character.

He who abstains from the pleasures of the body and rejoices in the abstinence is temperate, while he who is vexed at having to abstain is profligate; and again, he who faces danger with pleasure, or, at any rate, without pain, is courageous, but he to whom this is painful is a coward.

For moral virtue or excellence is closely concerned with pleasure and pain. It is pleasure that moves us to do what is base, and pain that moves us to refrain from what is noble. And therefore, as Plato says, man needs to be so trained from his youth up as to find pleasure and pain in the right objects. This is what sound education means. . . .

Virtue, then, is a habit or trained faculty of choice, the characteristic of which lies in observing the mean relatively to the persons concerned, and which is guided by reason, i. e., by the judgment of the prudent man.

And it is a moderation, firstly, inasmuch as it comes in the middle or mean between two vices, one on the side of excess, the other on the side of defect; and, secondly, inasmuch as, while these vices fall short of or exceed the due measure in feeling and in action, it finds and chooses the mean, middling, or moderate amount.

Regarded in its essence, therefore, or according to the 
definition of its nature, virtue is a moderation or middle etate, but viewed in its relation to what is best and right it is the extreme of perfection.

\section{VIRTUE AND VICE ALIKE VOLUNTARY}

$\mathrm{We}^{3}$ have seen that, while we wish for the end, we deliberate upon and choose the means thereto.

Actions that are concerned with means, then, will be guided by choice, and so will be voluntary.

But the acts in which the virtues are manifested are concerned with means.

Therefore, virtue depends upon ourselves; and vice likewise. For where it lies with us to do, it lies with us not to do. Where we can say no, we can say yes. If then the doing a deed, which is noble, lies with us, the not doing it, which is disgraceful, lies with us; and if the not doing, which is noble, lies with us, the doing, which is disgraceful, also lies with us. But if the doing and likewise the not doing of noble or base deeds lies with us, and if this is, as we found, identical with being good or bad, then it follows that it lies with us to be worthy or worthless men.

And so the saying,

None would be wicked, none would not be blessed,

seems partly false and partly true; no one indeed is blessed against his will; but vice is voluntary.

If we deny this, we must dispute the statements made just now, and must contend that man is not the originator and the parent of his actions, as of his children.

But if those statements commend themselves to us, and if we are unable to trace our acts to any other

'Arist. Ethics, III. 5, 1. 
sources than those that depend upon ourselves, then that whose source is within us must itself depend upon us and be voluntary.

This seems to be attested, moreover, by each one of us in private life, and also by the legislators; for they correct and punish those that do evil (except when it is done under compulsion, or through ignorance for which the agent is not responsible), and honor those that do noble deeds, evidently intending to encourage the one sort and discourage the other. But no one encourages us to do that which does not depend on ourselves, and which is not voluntary; it would be useless to be persuaded not to feel heat or pain or hunger and so on, as we should feel them all the same. . . .

[To the objection that a man's character is responsible for his misdeeds] we reply that men are themselves responsible for acquiring such a character by a dissolute life, and for being unjust or profligate in consequence of repeated acts of wrong, or of spending their time in drinking and so on. For it is repeated acts of a particular kind that give a man a particular character.

This is shown by the way in which men train themselves for any kind of contest or performance: they practise continually.

Not to know, then, that repeated acts of this or that kind produce a corresponding character or habit, shows an utter want of sense.

Moreover, it is absurd to say that he who acts unjustly does not wish to be unjust, or that he who behaves profligately does not wish to be profligate.

If then a man knowingly does acts which must make him unjust, he will be voluntarily unjust; but it does not follow that, if he wishes it he can cease to be unjust 
and be just, any more than he who is sick can, if he wishes it, be whole. And it may be that he is voluntarily sick, through living incontinently and disobeying the doctor. At one time, then, he had the option not to be sick, but he no longer has it now that he has thrown away his health. When you have discharged a stone it is no longer in your power to call it back; but nevertheless the throwing and casting away of that stone rest with you; for the beginning of its flight depended upon you. Just so the unjust or the profligate man at the beginning was free not to acquire this character, and therefore he is voluntarily unjust and profligate; but now that he has acquired it, he is no longer free to put it off.

But it is not only our mental or moral vices that are voluntary; bodily vices also are sometimes voluntary, and then are censured. We do not censure natural ugliness, but we do censure that which is due to negligence and want of exercise. And so with weakness and infirmity; we should never reproach a man who was born blind, or had lost his sight in an illness or by a blowwe should rather pity him; but we should all censure a man who had blinded himself by excessive drinking or any other kind of profligacy.

We see, then, that of the vices of the body it is those that depend on ourselves that are censured, while those that do not depend on ourselves are not censured. And if this be so, then in other fields also those vices that are blamed must depend upon ourselves.

\section{ON FRIENDSHIP}

It 4 is said that those who are blessed and self-sufficient have no need of friends; for they are already supplied

-Arist. Ethics, IX. 9, 1. 
with good things: as self-sufficient, then they need nothing more, while a friend is an alter ego who procures for you what you cannot procure yourself; whence the saying-

"When the gods favor you, what need of friends?"

But it seems strange, while endowing the happy man with all good things, to deny him friends, which are thought to be the greatest of all external goods. . . . Again, it is surely absurd to make the happy man a solitary being: for no one would choose to have all conceivable good things on condition of being alone; for man is a social being, and by nature adapted to share his life with others. The happy man, then, must have this good, since he has whatever is naturally good for man. But it is obvious that it is better to live with friends and good people, than with strangers and casual persons. The happy man, then, must have friends.

What, then, do those who maintain the former opinion mean? and in what sense are they right? Is it that the generality of men think that friends means useful people? Friends in this sense certainly the happy or blessed man will not need, as he already has whatever is good. And, again, he will have no need, or but little need, of the friendship that is based on pleasure; for his life is pleasant and does not require adventitious pleasure. Because he does not need these kinds of friends then, people come to think he does not need friends at all.

But I think we may say that this opinion is not true. For we said at the outset that happiness is a certain exercise of our faculties; but the exercise of our faculties plainly comes to be in time, and is not like a piece of property acquired once for all. But if happiness con- 
sists in living and exercising our faculties; and if the exercise of the good man's faculties is good and pleasant in itself, as we said at the outset; and if the sense that a thing belongs to us is one of the sources of pleasure, but it is easier to contemplate others than ourselves, and others' acts than our own-then the acts of the good men who are his friends are pleasant to the good man; for both the natural sources of pleasure are united in them. The happy or blessed man, then, will need such friends, since he desires to contemplate acts that are good and belong to him, and such are the acts of a good man who is his friend.

Again, it is thought that the happy man's life must be pleasant. Now, if he is solitary, life is hard for him; for it is very difficult to be continuously active by one's self, but not so difficult along with others, and in relation to others. With friends, then, the exercise of his faculties will be more continuous, being pleasant in itself. And this is what ought to be the case with the blessed man; for the good man, as such, delights in acts of virtue and is vexed by acts of vice, just as a musician is pleased by good music and pained by bad. . . . But the good man stands in the same relation to his friend as to himself, for his friend is another self: just as his own existence, then, is desirable to each, so, or nearly so, is his friend's existence desirable.

But existence, we found, is desirable because of the feeling that one's self is good, such a feeling being pleasant in itself.

The good man, then, should be conscious of the existence of his friend also, and this consciousness will be given by living with him and by rational converse with him (for this would seem to be the proper meaning of 


\section{SOURCE BOOK IN ANCIENT PHILOSOPHY}

living together, when applied to man, and not merely feeding in the same place, which it means when applied to beasts).

Putting all this together, then, if his own existence is desirable in itself to the good man, being naturally good and pleasant, and if his friend's existence is also desirable to him in nearly the same way, it follows that a friend is a desirable thing for him. But that which is desirable for him he ought to have, or in that respect he will be incomplete. Our conclusion, therefore, is that he who is to be happy must have good friends.

HIGHEST HAPPINESS FOUND IN THE VISION OF TRUTH

But ${ }^{5}$ if happiness be the exercise of virtue, it is reasonable to suppose that it will be the exercise of the highest virtue; and that will be the virtue or excellence of the best part of us.

Now, that part or faculty - call it reason or what you will-which seems naturally to rule and take the lead, and to apprehend things noble and divine-whether it be itself divine, or only the divinest part of us-is the faculty the exercise of which, in its proper excellence, will be perfect happiness.

That this consists in speculation or contemplation we have already said.

This conclusion would seem to agree both with what we have said above, and with known truths.

This exercise of faculty must be the highest possible; for the reason is the highest of our faculties, and of all knowable things those that reason deals with are the highest.

Again, it is the most continuous; for speculation can be - Arist. Ethics, X. 7, 1. 
carried on more continuously than any kind of action whatsoever.

We think, too, that pleasure ought to be one of the ingredients of happiness; but of all virtuous exercises it is allowed that pleasantest is the exercise of wisdom. At least philosophy is thought to have pleasures that are admirable in purity and steadfastness; and it is reasonable to suppose that the time passes more pleasantly with those who possess, than with those who are seeking knowledge.

Again, what is called self-sufficiency will be most of all found in the speculative life. The necessaries of life, indeed, are needed by the wise man as well as by the just man and the rest; but, when these have been provided in due quantity, the just man further needs persons towards whom, and along with whom, he may act justly; and so does the temperate and the courageous man and the rest; while the wise man is able to speculate even by himself, and the wiser he is the more is he able to do this. He could speculate better, we may confess, if he had others to help him, but nevertheless he is more selfsufficient than anybody else.

Again, it would seem that this life alone is desired solely for its own sake; for it yields no result beyond the contemplation itself, while from all actions we get something more or less besides the action itself.

Again, happiness is thought to imply leisure; for we toil in order that we may have leisure, as we make war in order that we may enjoy peace. . . .

This, then, will be the complete happiness of man, i. e., when a complete term of days is added; for nothing incomplete can be admitted into our idea of happiness.

But a life which realized this idea would be something 
more than human; for it would not be the expression of man's nature, but of some divine element in that nature - the exercise of which is as far superior to the exercise of the other kind of virtue [i. e., practical or moral virtue], as this divine element is superior to our compound human nature.

If then reason be divine as compared with man, the life which consists in the exercise of reason will also be divine in comparison with human life. Nevertheless, instead of listening to those who advise us as men and mortals not to lift our thoughts above what is human and mortal, we ought rather, as far as possible, to put off our mortality and make every effort to live in the exercise of the highest of our faculties; for though it be but a small part of us, yet in power and value it far surpasses all the rest.

And indeed this part would even seem to constitute our true self, since it is the sovereign and the better part. It would be strange, then, if a man were to prefer the life of something else to the life of his true self.

\section{HOW THE END IS TO BE REALIZED}

Now ${ }^{6}$ that we have treated (sufficiently, though summarily) of these matters, and of the virtues, and also of friendship and pleasure, are we to suppose that we have attained the end we proposed? Nay, surely the saying holds good, that in practical matters the end is not a mere speculative knowledge of what is to be done, but rather the doing of it. It is not enough to know about virtue, then, but we must endeavor to possess it and to use it, or to take any other steps that may make us good.

Now, if theories alone were sufficient to make people - Arist. Ethics, X. 9, 1. 
good, they would deservedly receive many and great rewards, to use the words of Theognis; but, in fact, it seems that though they are potent to guide and to stimulate liberal-minded young men, and though a generous disposition, with a sincere love of what is noble, may by them be opened to the influence of virtue, yet they are powerless to turn the mass of men to goodness. For the generality of men are naturally apt to be swayed by fear rather than by reverence, and to refrain from evil rather because of the punishment that it brings than because of its own foulness. For under the guidance of their passions they pursue the pleasures that suit their nature and the means by which those pleasures may be obtained, and avoid the opposite pains, while of that which is noble and truly pleasant they have not even a conception, as they have never tasted it.

What theories or arguments, then, can bring such men as these to order? Surely it is impossible, or at least very difficult, to remove by any argument what has long been ingrained in the character. For my part, I think we must be well content if we can get some modicum of virtue when all the circumstances are present that seen to make men good.

Now, what makes men good is held by some to be nature, by others habit [or training], by others instruction.

As for the goodness that comes by nature, it is plain that it is not within our control, but is bestowed by some divine agency on certain people who truly deserve to be called fortunate.

As for theory or instruction, I fear that it cannot avail in all cases, but that the hearer's soul must be prepared by training it to feel delight and aversion on 
the right occasions, just as the soil must be prepared if the seed is to thrive. For if he lives under the sway of his passions, he will not listen to the arguments by which you would dissuade him, nor even understand them. And when he is in this state, how can you change his mind by argument? To put it roundly, passion seems to yield to force only, and not to reason. The character, then, must be already formed, so as to be in some way akin to virtue, loving what is noble and hating what is base.

But to get right guidance from youth up in the road of virtue is hard, unless we are brought up under suitable laws; for to live temperately and regularly is not pleasant to the generality of men, especially to the young. Our nurture, then, should be prescribed by law, and our whole way of life; for it will cease to be painful as we get accustomed to it. And I venture to think that it is not enough to get proper nurture and training when we are young, but that as we ought to carry on the same way of life after we are grown up, and to confirm these habits, we need the intervention of the law in these matters also, and indeed, to put it roundly, in our whole life. For the generality of men are more readily swayed by compulsion than by reason, and by fear of punishment than by desire for what is noble. . . .

Now, the paternal rule has not the requisite force or power of compulsion, nor has the rule of any individual, unless he be a king or something like one; but the law has a compulsory power, and at the same time is a rational ordinance proceeding from a kind of prudence or reason. And whereas we take offence at individuals who oppose our inclinations, even though their opposition is right, we do not feel aggrieved when the law bids us do what is right. 


\section{XVII}

\section{THE STOICS $\dagger$}

THE PARTS OF PHILOSOPHY-THE CRITERION OF TRUTE

THE ${ }^{1}$ Stoics said that wisdom was a knowledge of things human and divine, and that philosophy was the practice of an art contrived to bring that knowledge about. The one art suitable to this purpose, and the highest of all, they said was virtue, but added that there were three generic virtues, the physical, the ethical, and the logical. And for this reason there are also three parts of philosophy, namely, physics, ethics, and logic. Whenever we investigate the cosmos, and the things that it contains, it is physics; when we are busily concerned about human life, it is ethics; when about reason, it is logic, or as it is also called, dialectic.

The ${ }^{2}$ Stoics said that some of the objects of sense and some of the objects of reason were true. The objects of sense, however, were not true straight off, but only in so far as they carried one back to their attendant objects of reason. True is that which belongs to and corresponds with something or other, false that which does not.

1 Aetius. Plac. I. (D. Dox. 273).

2 Bext. Emp. Adv. Math. VIII. 10.

† Zeno of Citium, the founder of the Stoic school, flourished about 300 в.C. Upon his death in 264 (?) he was succeeded by Cleanthes, who died about 220 . Chrysippus was born in 280 and died in 207. 
And ${ }^{3}$ they compare philosophy to an animal, likening logic to the bones and sinews, natural philosophy to the fleshy parts, and ethical philosophy to the soul. Again, they compare it to an egg; calling logic the shell, and ethics the white, and natural philosophy the yolk. Also to a fertile field; in which logic is the fence which goes round it, ethics are the fruit, and natural philosophy the soil, or the fruit-trees. Again, they compare it to a city fortified by walls, and regulated by reason; and then, as some of them say, no one part is preferred to another, but they are all combined and united inseparably; and so they treat of them all in combination. But others class logic first, natural philosophy second, and ethics third. . . .

Some again say that the logical division is properly subdivided into two sciences; namely, rhetoric and dialectics; and some divide it also into definitive species, which is conversant with rules and tests; while others deny the propriety of the last division altogether, and argue that the object of rules and tests is the discovery of the truth; for it is in this division that they explain the differences of representations. They also argue that, on the other side, the science of definitions has equally for its object the discovery of truth, since we only know things by the intervention of ideas. . . .

Demonstration they define to be a method by which one proceeds from that which is more known to that which is less. Perception, again, is an impression produced on the mind, its name being appropriately

3 From Diogenes Laertius, Yonge's translation, p. 274. The passages taken from Diogenes Laertius are all given in Yonge's translation, which, however, I have ventured to change in a few cases. 
borrowed from impressions on wax made by a seal; and perception they divide into perception which has convincing power, and perception which lacks convincing power. Perception which has convincing power-and this they call the criterion of facts - is produced by a real object, and is therefore at the same time conformable to that object. Perception which lacks convincing power has no relation to any real object, or else, if it has any such relation, docs not correspond to it, being but a vague and indistinct representation....

The Stoics have chosen to treat, in the first place, of perception and sensation, because the criterion by which the truth of facts is ascertained is a kind of perception, and because the judgment which expresses assent and conviction, and the understanding of a thing, a judgment which precedes all others, cannot exist without perception. For perception leads the way; and then thought, finding vent in expressions, explains in words the feelings which it derives from perception.

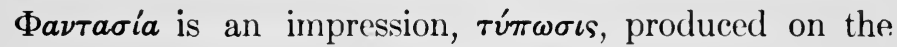
mind, that is to say, an alteration, $\dot{a} \lambda \lambda \lambda^{\prime} i \omega \sigma \iota$, as Chrysippus states in the twelf th book of his Treatise on the Soul. For we must not take this impression to resemble that made by a scal, since it is impossible to conceive that there should be many impressions made at the same time on the same thing. But davtaria is understood to be that which is impressed, and formed, and imprinted by a real object, according to a real object, in such a way as it could not be by any other than a real object; and, according to their ideas of the paviarial, some are sensible, and some are not. Those they call sensible, which are derived by us from some one or more senses; and those they call not sensible, which emanate 
directly from the thought, as, for instance, those which relate to incorporeal objects, or any others which are embraced by reason. Again, those which are sensible are produced by a real object, which imposes itself on the intelligence, and compels its acquiescence; and there are also some others, which are simply apparent, mere shadows, which resemble those which are produced by real objects. . . .

They say that the proper criterion of truth is the im-

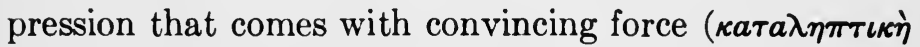

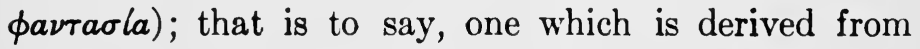
a real object, as Chrysippus asserts in the twelf th book of his Physics; and he is followed by Antipater and Apollodorus. For Boethius leaves a great many criteria, such as intellect, sensation, appetite, and knowledge; but Chrysippus dissents from his view, and in the first book of his Treatise on Reason, says that sensation and preconception are the only criteria. And preconception is, according to him, a comprehensive physical notion of general principles. But others of the earlier Stoics admit right reason as one criterion of the truth.

\section{ETHICS-FOLLOWING NATURE}

They ${ }^{4}$ say that the first inclination which an animal has is to protect itself, as nature brings herself to take an interest in it from the beginnirg, as Chrysippus affirms in the first book of his Treatise on Ends; where he says that the first and dearest object to every animal is its own existence, and its consciousness of that existence. For that it is not natural for any animal to be alienated from itself, or even to be brought into such a state as to be indifferent to itself, being neither alienated from nor

- From Diogenes Laertius, Yonge's translation, p. 290. 
interested in itself. It remains, therefore, that we must assert that nature has bound the animal to itself by the greatest unanimity and affection; for by that means it repels all that is injurious, and attracts all that is akin to it and desirable. But as for what some people say, that the first inclination of animals is to pleasure, they say what is false. For the Stoics say that pleasure, if there be any such thing at all, is an accessory only, which nature, having sought it out by itself, as well as those things which are adapted to its constitution, receives incidentally in the same manner as animals are pleased, and plants made to flourish.

Moreover, say they, nature makes no difference between animals and plants, when she regulates them so as to leave them without voluntary motion or sense; and some things too take place in ourselves in the same manner as in plants. But, as inclination in animals tends chiefly to the point of making them pursue what is appropriate to them, we may say that their inclinations are regulated by nature. And as reason is given to rational animals according to a more perfect principle, it follows, that to live correctly according to reason, is properly predicated of those who live according to nature. For nature is as it were the artist who produces the inclination.

On which account Zeno was the first writer who, in his Treatise on the Nature of Man, said that the chief good was confessedly to live according to nature; which is to live according to virtue, for nature leads us to this point. And in like manner Cleanthes speaks in his Treatise on Pleasure, and so do Posidonius and Hecaton in their essays on Ends and the Chief Good. And again, to live according to virtue is the same thing as living 


\section{SOURCE BOOK IN ANCIENT PHILOSOPHY}

according to one's experience of those things which happen by nature; as Chrysippus explains it in the first book of his Treatise on the Chief Good. For our individual natures are all parts of universal nature; on which account the chief good is to live in a manner corresponding to nature, and that means corresponding to one's own nature and to universal nature; doing none of those things which the common law of mankind is in the habit of forbidding, and that common law is identical with that right reason which pervades everything, being the same with Jupiter, who is the regulator and chief manager of all existing things.

Again, this very thing is the virtue of the happy man and the perfect happiness of life when everything is done according to a harmony with the genius of each individual with reference to the will of the universal governor and manager of all things. Diogenes, accordingly, says expressly that the chief good is to act according to sound reason in our selection of things according to our nature. And Archidemus defines it to be living in the discharge of all becoming duties. Chrysippus again understands, that the nature, in a manner corresponding to which we ought to live, is both the common nature, and also human nature in particular; but Cleanthes will not admit of any other nature than the common one alone, as that to which people ought to live in a manner corresponding; and repudiates all mention of a particular nature. And he asserts that virtue is a disposition of the mind always consistent and harmonious; that one ought to seek it out for its own sake, without being influenced by fear or hope of any external influence. Moreover, that it is in it that happiness consists, as producing in the soul the harmony of a life always consistent with itself, and that if a 
rational animal goes the wrong way, it is because it allows itself to be misled by the deceitful appearances of exterior things, or perhaps by the instigation of those who surround it; for nature herself never gives us any but good inclinations. . . .

And they lay down the position that all offences are equal, as Chrysippus argues in the fourth book of his Ethic Questions, and so say Persæus and Zeno. For if one thing that is true is not more true than another thing that is true, neither is one thing that is false more false than another thing that is false; so, too, one deceit is not greater than another, nor one sin than another. For the man who is a hundred furlongs from Canopus, and the man who is only one, are both equally not in Canopus; and so, too, he who commits a greater sin, and he who commits a less, are both equally not in the right path. . .

They say also that the wise man is free from perturbations because he has no strong propensities. But that this freelom from propensities also exists in the bad man, being, however, then quite another thing, inasmuch as it proceeds in hin only from hardness and unimpressibility of his nature. They also pronounce the wise man free from vanity, since he regards with equal eye what is glorious and what is inglorious. At the same time, they admit that there is another character devoid of vanity, who, however, is only reckoned one of the rash men, being in fact the bad man. They also say that all the virtuous men are austere, because they do never speak with reference to pleasure, nor do they listen to what is said by others with reference to pleasure. At the same time, they call another man austere too, using the term in nearly the same sense as they do when they 
speak of austere wine, which is used in compounding medicines, but not for drinking.

They also pronounce the wise to be honest-hearted men, anxiously attending to those matters which may make them better, by means of some principle which conceals what is bad, and brings to light what is good. Nor is there any hypocrisy about them; for they cut off all pretence in their voice and appearance. They also keep aloof from business; for they guard carefully against doing anything contrary to their duty. They drink wine, but they do not get drunk; and they never yield to frenzy. Occasionally, extraordinary imaginations may obtain a momentary power over them, owing to some melancholy or trifling, arising not according to the principle of what is desirable, but contrary to nature. Nor, again, will the wise man feel grief; because grief is an irrational contraction of the soul, as Apollodorus defines it in his Ethics. . . .

And they say that virtues reciprocally follow one another, and that he who has one has all; for that the precepts of them all are common. ... .

Another doctrine of the Stoics is, that there is nothing intermediate between virtue and vice; while the Peripatetics assert that there is a stage between virtue and vice, being an improvement on vice which has not yet arrived at virtue. For the Stoics say that as a stick must be either straight or crooked, so a man must be either just or unjust, and cannot be more just than just, or more unjust than unjust; and that the same rule applies to all cases. Moreover, Chrysippus is of opinion that virtue can be lost, but Cleanthes affirms that it cannot; the one saying that it can be lost by drunkenness or melancholy, the other maintaining that it cannot be 
lost on account of the firm perceptions which it implants in men. They also pronounce it a proper object of choice; accordingly, we are ashamed of actions which we do improperly, while we are aware that what is honorable is the only good. Again, they affirm that it is of itself sufficient for happiness. . . .

Again, they say that justice exists by nature, and not because of any definition or principle; just as law does, or right reason, as Chrysippus tells us in his Treatise on the Beautiful; and they think that one ought not to abandon philosophy on account of the different opinions prevailing among philosophers, since on this principle one would wholly quit life.

\section{THI HYMN OF CLEANTHES}

Most ${ }^{5}$ glorious of immortals, $\mathrm{O}$ thou of many names, all-powerful ever, hail! On thee it is fit all men should call. For we come forth from thee, and have received the gift of imitative speech alone of all that live and move on earth. So will I make my song of thee and chant thy power forever. Thee all this ordered universe, circling around the earth, follows as thou dost guide and evermore is ruled by thee. For such an engine hast thou in thine unswerving hands - the two-edged, blazing, everliving bolt-that at its blow all nature trembles. Herewith thou guidest universal Reason-the moving principle of all the world, joined with the great and lesser lights-which, being born so great, is highest lord of all. Nothing occurs on earth apart from thee, O Lord, nor at the airy sacred pole nor on the sea, save what the wicked work through lack of wisdom. But thou canst

- I am indebted to Prof. G. H. Palmer for this translation of the Hymn of Cleanthes. 
make the crooked straight, bring order from disorder, and what is worthless is in thy sight worthy. For thou hast so conjoined to one all good and ill that out of all goes forth a single everlasting Reason. This all the wicked seek to shun, unhappy men, who, ever longing to obtain a good, see not nor hear God's universal law; which, wisely heeded, would assure them noble life. They haste away, however, heedless of good, one here, one there; some showing unholy zeal in strife for honor, some turning recklessly toward gain, others to looseness and the body's pleasures. But thou, O Zeus, giver of all, thou of the cloud, guide of the thunder, deliver men from baleful ignorance! Scatter it, father, from our souls, grant us to win that wisdom on which thou thyself relying suitably guidest all; that thus being honored, we may return to thee our honor, singing thy works unceasingly; because there is no higher office for a mannor for a god-than ever rightly singing of universal law.

\section{PLUTARCH'S REFUTATION OF THE STOIC THEODICY†}

In $^{1}$ the third book of his Treatise on The Gods Chrysippus writes as follows: "Just as states which have a surplus population send great numbers out to colonies, and stir up wars against their neighbors, so God provides occasions for our destruction." And he cites Euripides and other writers who maintained that the Trojan War

1 Plutarch, De Stoicorum Repugnantiis, \$\$ 32-37.

$\dagger$ For the suggestion to include these interesting and illuminating passages from Plutarch I am indebted to Dr. B. A. G. Fuller, and the translation of them which is here given is his. 
was brought about by the gods because of the superabundancy of men.

Now leave aside all the other absurdities-for it is not our business here to inquire whether the Stoics have spoken the truth, but only whether they have contradicted themselves-and consider this one point. They are always giving fine and humane names to God, yet they attribute to him savage and barbarous deeds, yea, deeds worthy of the Galatæ. For the enormous destruction and wholesale slaughter of men such as was entailed by the Trojan War, or again by the Persian and the Peloponnesian Campaigns, bears no resemblance to colonization, unless the gods were intending to found some underground cities in Hades. Chrysippus rather makes God like one Deiotarus, chief of the Galatæ. He had many children born to him, but wished to leave his power and all his property to one alone. So he killed all the rest off, just as one might cut back and prune the new shoots of a vine, in order that some one which was left might grow strong and big. A vine-dresser, it goes without saying, does this, while the twigs are still small and insignificant. And we are merciful to the dog and destroy the surplus puppies just after they are born and before their eyes are yet open. But Zeus not only allows men to grow up; he even begets them himself and brings them up to manhoorl, and then, forsooth, carefully contrives occasions for their death and destruction and brutally sends them out of the world. I think he had better not have provided the causes and sources of our birth.

This, however, is of minor importance compared to what follows. No war arises among men without viciousness behind it. Love of luxury stirs up the one, avarice 
anotler, ambition a third, lust for power a fourth. Now if it be God who brings wars to pass, he is also the cause of our vices, provoking and perverting mankind as he does. Nevertheless Chrysippus says in his Treatise on Law Procedure, and again in the second book of his Treatise on The Gods, that "it is not reasonable that the deity should be the cause of base deeds. For just as a law cannot be the cause of its contravention, so neither can the gods be the cause of impiety. It is then reasonable that they should not be the causes of anything base."

But, I say, can anything be more base than that men should destroy one another? And for this destruction Chrysippus says that God is responsible. I will swear to it, however, that some one will say that he also praises the saying of Euripides:

If gods do aught that's base, they are not gods,

and

Thou say'st an easy thing-to blame the gods,

as if we were now doing anything but showing up his contradictory sayings and ideas.

This very saying, however, which now meets with approval, "Thou say'st an easy thing-to blame the gods"- can be urged against Chrysippus not once, or twice, or thrice, but innumerable times. For in the first book in the Treatise on Nature, in likening the cause of motion to a mixture of things whirling and churning in all directions, he speaks thus, "Since the worldeconomy proceeds in this fashion, it is due to it that we are as we are at every moment, whether contrary to our proper nature we suffer disease or disability, or be grammarians or musicians." And again a little later he 
says, "By this reasoning the same holds true of our virtues and vices, and in general of our skill in the arts or lack of it, as I have said." And a line or two later, without any ambiguity he remarks, "No single or slightest thing can happen except in accordance with the common nature and its reason." That the common nature and the common reason of this nature are fate, and providence, and Zeus, is something of which not even the dwellers in the antipodes are unaware, for this truth is noised about by the Stoics everywhere, and Chrysippus remarks "that Homer rightly said, 'The will of Zeus is done,' referring to that fate and that nature of the universe according to which all things are governed."

How now, I ask, can God be the author of nothing base, and yet at the same time not the slightest thing happen otherwise than according to the common nature and its reason? For since evils belong in the sum of events they are, I presume, to be ascribed to God. Even Epicurus turns and twists and thinks up subtleties to free and release the will from the eternal motion of the worldmechanism, in order that vice may not be left blameless. Chrysippus, however, concedes to vice complete license, as something which is not only necessary and destined, but also in accordance with the divine reason, and produced agreeably to that nature which is supremely good. Look, for instance, at this statement of his: "The common nature is spread throughout all things, and hence everything whatsoever which happens in the universe and every part thereof happens in accordance with it and its reason, and follows therefrom without any hindrance. For there is nothing outside the universe to oppose its workings, nor can any one of its parts be moved or conditioned otherwise than agreeably to the 
common nature." What, now, are the conditions and motions of its parts? Evidently the conditions are vices and diseases, avarice, luxury, ambition, fear, injustice; and the motions are adultery, theft, treachery, murder, and parricide. None of these, then, great or small, is thought by Chrysippus to exist contrary to the reason, the law, the justice, the providence of Zeus, nor do lawless acts exist contrary to law, nor injustice to justice, nor evil-doing to providence.

Chrysippus says, however, "that God punishes vice, and does much in the way of punishing wicked men." Likewise in the second book of the Treatise on The Gods he says that "misfortunes happen sometimes to good men, not for punishment as with the wicked, but in accordance with some other line of administration, as in the case of cities." Again, his words run as follows: "In the first place evils are to be understood in pretty much the aforesaid way, and secondly as apportioned according to the reason of Zeus, either for punishment, or agreeably to some other scheme of administration to the advantage of the whole." It is, however, a horrible thing that vice should be both produced and punished agreeably to the reason of Zeus. And Chrysippus pushes the contradiction still further when he writes in the second book of the Treatise on Nature, that "Vice has a peculiar and reasonable fitness viewed in relation to terrible calamities. It is produced in a way agreeably to the universal reason, and its production is not without benefit to the universe. For without it, there would be no good." And this is the man who reproves those who argue with equal force to the opposite conclusion; this man who, wishing in every case to get off some odd and subtle remark about the universe, maintains that cut- 
pursing and flattery and foolishness are not without their uses, that the good for nothing are good for something, and the noxious and the miserable are not unbeneficial. Again what kind of a being is Zeus-I mean, of course, Chrysippus's Zeus-to punish what is neither responsible for itself nor uselessly produced? For according to Chrysippus's way of arguing, it is not vice that is to be blamed, but Zeus, either because he made vice to no use, or because, having made it to some use, he punishes it.

Once more, in the first book of the Treatise on Justice, Chrysippus says that the gods resist some unjust deeds, yet that "it is neither possible nor expedient to remove vice from the universe." If, however, it be inexpedient to do away with lawlessness, injustice, and foolishness, it is impossible for him to pursue his present argument. For he himself in doing all he can by philosophizing to do away with vice-which it is not expedient to do away with-is doing something repugnant both to reason and to God. Yet when he says as well that the gods resist some unrighteous deeds, he gives the impression that these sins are impious.

In another place where he writes many times that nothing is blameworthy or contemptible in the universe, since everything takes place agreeably to the supremely good nature, there are yet passages where some neglect in small and mean matters is allowed not to be reprehensible. Thus in the third book of the Treatise on Substance, in reminding us that noble and good men are the victims of such neglect, he asks "whether some things may not be neglected, just as in great houses some grains of corn and wheat fall unnoticed, though the household as a whole is well managed? Or is this neglect due to the presence in such cases of evil spirits, in whom a 
reprehensible carelessness is naturally inherent?" And he adds that there is a large admixture of necessity in things. Now I pass over the recklessness of likening to the unnoticed fall of grains of wheat such misfortunes of good and noble men as the condemnation of Socrates, and the burning alive of Pythagoras by the Cylonians, and the torture and death of Zeno at the hands of the tyrant Demylus, and of Antiphon by Dionysius. But is it not to blame God, to say that evil spirits were providentially appointed to such offices? For God in that case would be like a king who handed over his provinces to evil and stupid satraps and generals, and then overlooked their neglect and ill-treatment of his best subjects. Finally, if there be a large admixture of necessity in things, God is not all powerful and all things are not administered according to his word.

But ${ }^{2}$ what fault can any one find with what I have said if he keeps in mind the passage in the second book of the Treatise on Nature in which Chrysippus shows that evil is produced to some benefit to the universe? It is worth while to take this doctrine and compare it with those sayings of his in which you will find he accuses Xenocrates and Speusippus of not regarding health as indifferent, and wealth as useless, and in the same place defines vice, and discourses about it. "Vice," he says, "is distinguished from other calamities. For it happens agreeably to the rational constitution of nature, and, so to speak, does not happen without some benefit to the universe. For did it not exist there would be no good."

There is then nothing good among the gods when there is nothing evil. When Zeus shall have consumed

- De Communibus Notitiis, \$§ 13-16. 
the whole of matter within himself, and shall have become one, having cast out all differences and distinctions, then there will be no good, since there is no evil. Still, one might object, a chorus can sing in harmony, though no one in it sing out of tune; and a body can be healthy even though no part of it be diseased.

However, Chrysippus maintains that virtue cannot exist without vice, and that just as the venom of the serpent or the bile of the hyena is necessary to the efficacy of some medicines, so a suitable admixture of the wickedness of Meletus is necessary to the righteousness of Socrates, or of the vulgarity of Cleon to the nobility of Pericles. How, too, could Zeus create Hercules and Lycurgus, unless he also created Sardanapalus and Phalaris for us? Chrysippus might as reasonably add, also, that tuberculosis promotes human health, and gout swiftness of foot; also that Achilles could not have had a fine head of hair unless Thersites had been bald. For what is the difference between such nonsense and drivel, and saying that wantonness conduces to continence, or unrighteousness to righteousness? And how are we to pray the gods that

\section{Lies and oily words and wily ways}

may be ever evil in their sight, if virtue also vanishes and is destroyed when they are done away with?

Would you really like to know, however, the most charming bit of his smoothness and persusu:ion? "Just as comedians," he says, "put in ridiculous lines which are poor stuff in themselves but lend a certain charm to the whole piece, so what you censure as evil, taken by itself, is not without its use in relation to other things." Now, in the first place, that vice has been produced by 
divine providence, as a poor line is intentionally written by the playwright, is the most absurd of opinions. Supposing it were so, how should the gods be any more the givers of good than of evil? How could vice be inimical to the gods, and hateful in their sight? What could we reply to such blasphemy as

When God will injure mortals he creates the reason why and

Who forced them to fight in the battles of gods?

In the second place the poor line adorns the comedy and contributes to its purpose of arousing laughter and pleasing the audience. But surely father Zeus, the most high, the all-just, the all-good creator, as Pindar calls him, did not make this world as a big and varied and clever play, but as a commonwealth of gods and men wherein they might live together as comrades amid righteousness and virtue in concord and blessedness. And to this most beautiful and holy end, I say, what need was there of robbers and murderers, parricides and syrants? For in the eyes of God vice is not a charming and clever by-play, nor is unrighteousness inflicted for the sake of coarse joking and laughter and jest, upon human life-a life such that it will not permit one even to dream of the Stoics' renowned "harmony."

Again the poor line is but a trivial part of the play and in all respects occupies but a small place in the comedy. There are not many such lines, and they do not destroy or spoil the charm of such passages as seem well-written. But all things are full of vice, and our whole life from the cradle to the grave is shameful and disgraceful and troublous, and as there is no part of it 
pure and blameless, as they themselves say, is the basest and saddest of all plays.

So it is that I would gladly learn from Chrysippus of what use vice is in the universe. It is of no use to heavenly and divine things, he says. For it would be absurd if for the lack among men of vice and avarice and lying, and for the want of our ravaging one another's lands and slandering and nurlering one another, the sun could not accomplish his appointed course, nor the world enjoy its seasons and its cycles, nor the earth keep its central position in the universe and provide the sources of the winds and rains. It is left then for vice to benefit us and our affairs; and this perhaps is what these Stoics mean. But are we healthier for being vicious, or better off as regards the necessities of life? Does vice benefit our beauty or our strength? They deny it. Yet where is virtue to be found on earth? "It is," they say, "a name, an appearance in the night to benighted" sophists. Vice, however, is exposed to every waking eye, and plain as day to all men. If, however, we cannot have a share in anything good for anything, and least of all in virtue, for heaven's sake what is the good of being born? And is it not a terrible thing that though what is of use to the farmer or the pilot or the driver leads and contributes to its proper end, yet that which is created by God for virtue destroys and corrupts virtue?

$$
*^{*} *
$$

Moreover, ${ }^{3}$ the Stoic sage doesn't and never will exist anywhere in this world. But there are innumerable men as wretched as they can be living in this state and principality of Zeus with its perfect government. What now is more contrary to common sense than that, with

De Communibus Notitiis, § 33, 4-34. 
Zeus directing all things for the best, we should be doing all things for the worst? It is a blasphemous thing to say, but if Zeus does not care to be considered as savior and merciful and a guardian against evils, but as rather the opposite of all these noble names, certainly nothing could be added to the evils that now exist either in number or magnitude. For, as the Stoics maintain, all men live in the depths of folly and wickedness, and there can be no addition to their viciousness nor increase to their misery.

This, however, is not the worst of the case. We read that rather where they find fault with Menander for saying in one of his acted plays,

No greater source of evils among men is there than too great good ...

This they say is contrary to common-sense. Yet they make God who is good the origin of evil. "Matter," they say, "cannot produce evil of itself, since it is without quality and gets all the different properties which it is capable of receiving from that which moves and gives it form." The indwelling reason, however, moves and gives it form, and it cannot move or give form to itself. Hence necessarily evil, if it have no cause, comes from not-being, but if it comes through the moving principle, gets its existence from God. For if the Stoics think that Zeus is not the master of his own members, and does not employ each agreeably to his reason, they go contrary to common-sense, and they are inventing an animal whose many members do not obey its will, but employ their several activities and ways of action, without any stimulus from the whole organism and without deriving their power of movement from it. What animal, 
however, is so badly put together that against its will its feet advance, its tongue makes noises, its horns butt, or its teeth bite? God must do most of these things, though, if, contrary to his will, the wicked men who are parts of him lie and misbehave and thieve, and kill one another. And if, as Chrysippus says, "Not the smallest part exists otherwise than as Zeus wills," and every living thing naturally behaves and moves as Zeus guides and directs and behaves and disposes, then

More ruinous than the last, this speech.

For it is ten thousand times more decent that the members of Zeus, deranged by his weakness and impotence, should do many absurd things contrary to his nature and will, than that there should be no wantonness and no wickedness of which he was not the cause. Yet for all that "the world is a city, the stars its citizens," and, if you like, its tribesmen and rulers-the sun for instance a counsellor, and the evening star the president of a prytany or a magistrate. If this be the case I do not think that they who deny the doctrines we have been discussing, show themselves to be any more absurd than those who maintain and advocate them. 


\section{XVIII}

\section{EPICURUS}

[341-270 B.c.]

\section{THEORY OF KNOWLEDGE}

First ${ }^{1}$ of all, then, one must determine with exactness the notion comprehended under each separate word, in order to be able to refer to it, as to a certain criterion, the conceptions which emanate from ourselves, the ulterior researches and the difficulties; otherwise the judgment has no foundation. One goes on from demonstration to demonstration ad infinitum; or else one gains nothing beyond mere words. In fact, it is absolutely necessary that in every word we should perceive directly, and without the assistance of any demonstration, the fundamental notion which it expresses, if we wish to have any foundation to which we may refer our researches, our difficulties, and our personal judgments, whatever in other respects may be the criterion which we adopt, whether we take as our standard the impressions produced on our senses, or the actual impression in general; or whether we cling to the idea by itself, or to any other criterion.

We must also note carefully the impressions which we receive in the presence of objects, in order to bring ourselves back to that point in the circumstances in which

${ }^{1}$ From Diogenes Laertius, Yonge's translation, pp. $437 \mathrm{ff}$. This and the following division are taken from Enicurus's letter to Herodotus. 
it is necessary to suspend the judgment; or even when the question is about things, the evidence of which is not immediately perceived.

When these foundations are once laid we may pass to the study of those things, the evidence of which is not immediate. . .

One must not forget that the production of images is simultaneous with the thought; for from the surface of the bodies images of this kind are continually flowing off in an insensible manner indeed, because they are immediately replaced. They preserve for a long time the same disposition, and the same arrangement that the atoms do in the solid body, although, notwithstanding, their form may be sometimes altered. The direct production of images in space is equally instantaneous, because these images are only light substances destitute of depth.

But there are other manners in which natures of this kind are produced; for there is nothing in all this which at all contradicts the senses, if one only considers in what way the senses are exercised, and if one is inclined to explain the relation which is established between external objects and ourselves. Also, one must admit that something passes from external objects into us in order to produce in us sight and the knowledge of forms; for it is difficult to conceive that external objects can affect us through the medium of the air which is between us and them, or by means of rays, whatever emissions proceed from us to them, so as to give us an impression of their form and color. This phenomenon, on the contrary, is perfectly explained, if we admit that certain images of the same color, of the same shape, and of a proportionate magnitude pass from these objects to us, 
and so arrive at being seen and comprehended. These images are animated by an exceeding rapidity, and, as on the other side, the solid object forming a compact mass, and comprising a vast quantity of atoms, emits always the same quantity of particles, the vision is continued, and only produces in us one single perception which preserves always the same relation to the object. Every conception, every sensible perception which bears upon the form or the other attributes of these images, is only the same form of the solid perceived directly, either in virtue of a sort of actual and continued condensation of the image, or in consequence of the traces which it has left in us.

Error and false judgments always come from our adding in certain imaginings of our own which are occasioned by some motion in our own bodies, which motion in turn is connected with some impression or direct representation, but also connected with some opinion peculiar to ourselves, which is the parent of error. In fact the representations which intelligence reflects like a mirror, whether one perceives them in a dream, or by any other conceptions of the intellect, or of any other of the criteria, can never resemble the objects that one calls real and true, unless there were objects of this kind perceived directly. And, on the other side, error could not be possible if we did not receive some other motion also, a sort of initiative of intelligence connected, it is true, with direct representation, but going beyond that representation. These conceptions being connected with the direct perception which produces the representation, but going beyond it, in consequence of a motion peculiar to the individual thought, produce error when it is not confirmed by evidence, or when it is contradicted by evi- 
dence; but when it is confirmed, or when it is not contradicted by evidence, then it produces truth.

We must carefully preserve these principles in order not to reject the authority of the faculties which perceive truth directly; and not, on the other hand, to allow what is false to be established with equal firmness, so as to throw everything into confusion.

\section{PHYSICAL SPECULATIONS}

And, first of all, we must admit that nothing can come of that which does not exist; for, were the fact otherwise, then everything would be produced from everything, and there would be no need of any seed. And if that which disappeared were so absolutely destroyed as to become nonexistent, then everything would soon perish, as the things with which they would be dissolved would have no existence. But, in truth, the universal whole always was such as it now is, and always will be such. For there is nothing into which it can change; for there is nothing beyond this universal whole which can penetrate into it, and produce any change in it. . . .

The universe is infinite. For that which is finite has an extreme, and that which has an extreme is looked at in relation to something else. Consequently, that which has not an extreme, has no boundary; and if it has no boundary, it must be infinite, and not terminated by any limit.

Again: the atoms which form the bodies, these full elements from which the combined bodies come, and into which they resolve themselves, assume an incalculable variety of forms, for the numerous differences which the bodies present cannot possibly result from an aggregate of the same forms, [and] the atoms are in a continual state of motion. . . . 
Among the atoms, some are separated by great distances, others come very near to one another in the formation of combined bodies, or at times are enveloped by others which are combining; but in this latter case they, nevertheless, preserve their own peculiar motion, thanks to the nature of the vacuum, which separates the one from the other, and yet offers them no resistance. The solidity which they possess causes them, while knocking against one another, to react the one upon the other; till at last the repeated shocks bring on the dissolution of the combined body; and for all this there is no external cause, the atoms and the vacuum being the only causes. . . .

One must also allow that the atoms possess no one of the qualities of sensible objects, except form, weight, magnitude, and anything else that is unavoidably inherent in form; in fact every quality is changeable, but the atoms are necessarily unchangeable; for it is impossible but that in the dissolution of combined bodies, there must be something which continues solid and indestructible, of such a kind, that it will not change either into what does not exist, or out of what does not exist; but that it results either from a simple displacement of parts, which is the most usual case, or from the addition or subtraction of certain particles. . . .

Moreover, all the atoms are necessarily animated by the same rapidity, when they move across the vacuum, or when no obstacle thwarts them. For why should heavy atoms have a more rapid movement than those which are small and light, since in no quarter do they encounter any obstacle? Why, on the other hand, should the small atoms have a rapidity superior to that of the large ones, since both the one and the other find 
everywhere an easy passage, from the very moment that no obstacle intervenes to thwart their movements? Movement from low to high, horizontal movement to and fro, in virtue of the reciprocal percussion of the atoms, movement downward, in virtue of their weight, will be all equal, for in whatever sense the atom moves it must have a movement as rapid as the thought, till the moment when it is repelled, in virtue of some external cause, or of its own proper weight, by the shock of some object which resists it. . . . At the same time, an atom has not, in any moment perceptible to the intelligence, a continued movement in the same direction; but rather a series of oscillating movements from which there results, in the last analysis, a continued movement perceptible to the senses. ...

Let us now return to the study of the affections, and of the sensations; for this will be the best method of proving that the soul is a bodily substance composed of slight particles, diffused over all the members of the body, and presenting a great analogy to a sort of spirit, having an admixture of heat, resembling at one time one, and at another time the other of those two principles. There exists in it a special part, endowed with an extreme mobility, in consequence of the exceeding slightness of the elements which compose it, and also in reference to its more immediate sympathy with the rest of the body. That it is which the faculties of the soul sufficiently prove, and the passions, and the mobility of its nature, and the thoughts, and, in a word, everything, the privation of which is death. We must admit that it is in the soul most especially that the principle of sensation resides. At the same time it would not possess this power if it were not enveloped by the rest of the body 
which communicates it to it, and in its turn receives it from it, but only a certain measure; for there are certain affections of the soul of which it is not capable.

\section{THE PRACTICAL PHILOSOPHY OF EPICURUS}

Let ${ }^{2}$ no one delay to study philosophy while he is young, and when he is old let him not become weary of the study; for no man can ever find the time unsuitable or too late to study the health of his soul. And he who asserts either that it is not yet time to philosophize, or that the hour is passed, is like a man who should say that the time is not yet come to be happy, or that it is too late. So that both young and old should study philosophy, the one in order that, when he is old, he may be young in good things through the pleasing recollection of the past, and the other in order that he may be at the same time both young and old, in consequence of his absence of fear for the future.

It is right then for a man to consider the things which produce happiness, since, if happiness is present, we have everything, and when it is absent, we do everything with a view to possess it. Now, what I have constantly recommended to you, these things I would have you do and practise, considering them to be the elements of living well. First of all, believe that God is a being incorruptible and happy, as the common opinion of the world about God dictates; and attach to your idea of him nothing which is inconsistent with incorruptibility or with happiness; and think that he is invested with everything which is able to preserve to him this happiness, in conjunction with incorruptibility. For there are

${ }^{2}$ This passage is from the letter of Epicurus addressed to Menæceus. Dingenes Laertius, Yonge's translation, p. 468. 
gods; though our bnorledge of them is indistinct. But ther sre not of the charscter which people in geveral sttribute to them: for ther do not par s respect to them which sccords with the idess thst they entersin of them. And that man is not impious who discsind the gads believed in by the many, but he tho spplies to the gods the opinions entertsinel of them by the mont. For the ssertions ct the many stout the gods ste not

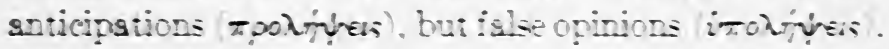
And in consequence of these. the grestes erils which twiall wicked men, snd the brenefis which sre conierred on the good, sre all stributed to the gouls: for they connect sll their idess of them with s comprison of humsn rirtues, sad everyhing which is different from human quslitis they regsh so incompatible with the divine nsture.

Accustom yourself sloo to inink desth s meter with which we sre not st sll concerteit. since sll goot snd all eril is in seastion. and since desth is only the prirstion of senstion. On mich serount. the correct knomleige of the isct that desth is no concern ot ours. mates the mortslity of life plessent to us inswmeh ss it sets forth no illimitsble time, but relieves us fom the longing for immortality. For there is noting ierihle in living to s men who righty comprehends thst there is nothing terrible in cessing to live: so hat he mas s slly man who ssid that he fested desth. not fwesuse it mould greve him when it was present, but becsuse it dit grove him While it $\pi \mathrm{g}$ iuture. For it is rey sheurt ins: ins: which does not distress s man when it is present. should sffict him mhen only exroted. Trestore the mast formidsble of all sills. desth. is nothing to us. since, when we exist. Cesth is not prisent to us: and 
when death is present, then we have no existence. It is no concern then either of the living or of the dead; since to the one it has no existence, and the other class has no existence itself. But people in general at times flee from death as the greatest of evils, and at times wish for it as a rest from the evils in life. Nor is the not living a thing feared, since living is not connected with it; nor does the wise man think not living an evil; but, just as he chooses food, not preferring that which is most abundant, but that which is nicest; so, too, he enjoys time, not measuring it as to whether it is of the greatest length, but as to whether it is most agreeable. And he who enjoins a young man to live well, and an old man to die well, is a simpleton, not only because of the constantly delightful nature of life, but also because the care to live well is identical with the care to die well. And he was still more wrong who said:

'Tis well to taste of life, and then when born

To pass with quickness to the shades below.

For if this really was his opinion why did he not quit life? for it was easily in his power to do so, if it really was his belief. But if he was joking, then he was talking foolishly in a case where it ought not to be allowed; and we must recollect that the future is not our own, nor, on the other hand, is it wholly not our own, I mean so that we can never altogether await it with a feeling of certainty that it will be, nor altogether despair of it as what will never be. And we must consider that some of the passions are natural, and some empty; and of the natural ones some are necessary, and some merely natural. And of the necessary ones some are necessary to happiness, others are necessary that the body may be 
exempt from trouble, and others, again, merely in order that life itself may be; for a correct theory, with regard to these things, can refer all choice and avoidance to the health of the body and the imperturbability of the soul, since this is the end of living happily. For it is for the sake of this that we do everything, wishing to avoid grief and fear; and when once this is the case, with respect to us, then the storm of the soul is, as I may say, put an end to; since the animal is unable to go as if to something deficient, and to seek something different from that by which the good of the soul and body will be perfected.

For then we have need of pleasure when we grieve, because pleasure is not present; but when we do not grieve, then we have no need of pleasure; and on this account, we affirm that pleasure is the beginning and end of living happily; for we have recognized this as the first good, being connate with us; and it is with reference to it that we begin every choice and avoidance; and to this we come as if we judged of all good by passion as the standard; and, since this is the first good and connate with us, on this account we do not choose every pleasure, but at times we pass over many pleasures when any difficulty is likely to ensue from them; and we think many pains better than pleasures, when a greater pleasure follows them, if we endure the pain for a time.

Every pleasure is therefore a good on account of its own nature, but it does not follow that every pleasure is worthy of being chosen; just as every pain is an evil, and yet every pain must not be avoided; but it is right to estimate all these things by the measurement and view of what is suitable and unsuitable; for at times we may feel the good as an evil, and at times, on the con- 
trary, we may feel the evil as good. And we think contentment a great good, not in order that we may never have but a little, but in order that, if we have not much, we may make use of a little, being genuinely persuaded that those men enjoy luxury most completely who are the best able to do without it; and that everything which is natural is easily provided, and what is useless is not easily procured. And simple flavors give as much pleasure as costly fare, when everything that can give pain, and every feeling of want, is removed; and corn and water give the most extreme pleasure when any one in need eats them. To accustom one's self, therefore, to simple and inexpensive habits is a great ingredient in the perfecting of health, and makes a man free from hesitation with respect to the necessary uses of life. And when we, on certain occasions, fall in with more sumptuous fare, it makes us in a better disposition toward it, and renders us fearless with respect to fortune. When, therefore, we say that pleasure is a chief good, we are not speaking of the pleasures of the debauched man, or those which lie in sensual enjoyment, as some think who are ignorant, and who do not entertain our opinions, or else interpret them perversely; but we mean the freedom of the body from pain, and of the soul from confusion. For it is not continued drinkings and revels, or the enjoyment of female society, or feasts of fish and other such things as a costly table supplies, that make life pleasant, but sober contemplation, which examines into the reasons for all choice and avoidance, and which puts to flight the vain opinions from which the greater part of the confusion arises which troubles the soul.

Now, the beginning and the greatest good of all these 
things is prudence, on which account prudence is something more valuable than even philosophy, inasmuch as all the other virtues spring from it, teaching us that it is not possible to live pleasantly unless one also lives prudently, and honorably, and justly; and that one cannot live prudently, and honorably, and justly, without living pleasantly; for the virtues are connate with living agreeably, and living agreeably is inseparable from the virtues. Since, who can you think better than that man who has holy opinions respecting the gods, and who is utterly fearless with respect to death, and who has properly contemplated the end of nature, and who comprehends that the chief good is easily perfected and easily provided; and the greatest evil lasts but a short period, and causes but brief pain? And who has no belief in necessity, which is set up by some as the mistress of all things, but he refers some things to fortune, some to ourselves, because necessity is an irresponsible power, and because he sees that fortune is unstable, while our own will is free; and this freedom constitutes, in our case, a responsibility which makes us encounter blame and praise. Since it would be better to follow the fables about the gods than to be a slave to the fate of the natural philosopher; for the fables which are told give us a sketch, as if we could avert the wrath of God by paying him honor; but the other presents us with necessity which is inexorable.

And he, not thinking fortune a goddess, as the generality esteem her (for nothing is done at random by a god), nor a cause which no man can rely on; for he thinks that good or evil is not given by her to men so as to make them live happily, but that the principles of great goods or great evils are supplied by her; thinking it better to 
be unfortunate in accordance with reason, than to be fortunate irrationally; for that those actions which are judged to be the best, are rightly done in consequence of reason.

Do you then study these precepts, and those which are akin to them, by all means day and night, pondering on them by yourself, and discussing them with any one like yourself, and then you will never be disturbed by either sleeping or waking fancies, but you will live like a god among men; for a man living amid immortal gods is in no respect like a mortal being.

\section{SOME MAXIMS OF EPICURUS}

$\mathrm{No}^{3}$ pleasure is intrinsically bad; but the efficient causes of some pleasures bring with them a great many perturbations of pleasure.

If every pleasure were condensed, if one may so say, and if each lasted long, and affected the whole body, or the essential parts of it, then there would be no difference between one pleasure and another.

Irresistible power and great wealth may, up to a certain point, give us security as far as men are concerned; but the security of men in general depends upon the tranquillity of their souls, and their freedom from ambition.

The riches of nature are defined and easily procurable; but vain desires are insatiable.

The wise man is but little favored by fortune; but his reason procures him the greatest and most valuable 3 From Diogenes Laertius, Yonge's translation, p. 474. 
goods, and these he does enjoy, and will enjoy the whole of his life.

He who is acquainted with the limits of life knows that that which removes the pain which arises from want, and which makes the whole of life perfect, is easily procurable; so that he has no need of those things which can only be attained with trouble.

Of all the things which wisclom provides for the happiness of the whole life, by far the most important is the acquisition of friendship.

He who desires to live tranquilly without having anything to fear from other men, ought to make himself friends; those whom he cannot make friends of, he should, at least, avoid rendering enemies; and if that is not in his power, he should, as far as possible, avoid all intercourse with them and keep them aloof, as far as it is for his interest to do so.

The happiest men are they who have arrived at the point of having nothing to fear from those who surround them. Such men can live with one another most agreeably, having the firmest grounds of confidence in one another, enjoying the advantages of friendship in all their fulness, and not lamenting, as a pitiable circumstance, the premature death of their friends.

Natural justice is a covenant of what is suitable, leading men to avoid injuring one another, and being injured.

Justice has no independent existence; it results from mutual contracts, and establishes itself wherever there 
is a mutual engagement to guard against doing or sustaining mutual injury.

In a general point of view, justice is the same thing to every one; for there is something advantageous in mutual society. Nevertheless, the difference of place, and divers other circumstances, make justice vary.

From the moment that a thing declared just by the law is generally recognized as useful for the mutual relations of men, it becomes really just, whether it is universally regarded as such or not.

But if, on the contrary, a thing established by law is not really useful for the social relations, then it is not just.

The just man is the freest of all men from disquietude; but the unjust man is a perpetual prey to it. 


\section{XIX}

\section{LUCRETIUS}

[96-55 в.c.]

THE WAGES OF PHILOSOPHY

For ${ }^{1}$ I will essay to discourse to you of the most high system of heaven and the gods and will open up the firstbeginnings of things, out of which nature gives birth to all things and increase and nourishment, and into which nature likewise dissolves them back after their destruction. These we are accustomed in explaining their reason to call matter and begetting bodies of things and to name seeds of things and also to term first bodies, because from them as first elements all things are.

It ${ }^{2}$ is sweet, when on the great sea the winds trouble its waters, to behold from land another's deep distress; not that it is a pleasure and delight that any should be afflicted, but because it is sweet to see from what evils you are yourself exempt. It is sweet also to look upon the mighty struggles of war arrayed along the plains without sharing yourself in the danger. But nothing is more welcome than to hold the lofty and serene positions well fortified by the learning of the wise, from which you may look down upon others and sce them wandering all

1 The extracts from Lucretius are given in Munro's translation, and the page references are to the translation. P. 2.

2 Ib., p. 28. 
abroad and going astray in their search for the path of life, see the contest among them of intellect, the rivalry of birth, the striving night and day with surpassing effort to struggle up to the summit of power and to be masters of the world. O miserable minds of men! $O$ blinded breasts! in what darkness of life and in how great dangers is passed this term of life whatever its duration! not choose to see that nature craves for herself no more than this, that pain hold aloof from the body, and that she in mind enjoy a feeling of pleasure exempt from care and fear! Therefore we see that for the body's nature few things are needed at all, such and such only as take away pain.

For ${ }^{3}$ even as children are flurried and dread all things in the thick darkness, thus we in the daylight fear at times things not a whit more to be dreaded than those which children shudder at in the dark and fancy sure to be. This terror therefore and darkness of mind must be dispelled not by the rays of the sun and glittering shafts of day, but by the aspect and law of nature.

Now mark and I will explain by what motion the begetting bodies of matter do beget different things and after they are begotten again break them up, and by what force they are compelled so to do and what velocity is given to them for travelling through the great void: do you mind to give heed to my words. For verily matter does not cohere inseparably massed together, since we see that everything wanes and perceive that all things ebb as it were by length of time and that age withdraws them from our sight, though yet the sum is seen to remain unimpaired by reason that the bodies which

${ }^{3}$ Munro's translation, pp. 29-30. 
quit each thing, lessen the things from which they go, gift with increase those to which they have come, compel the former to grow old, the latter to come to their prime, and yet abide not with these. Thus the sum of things is ever renewed and mortals live by a reciprocal dependency. Some nations wax, others wane, and in a brief space the races of living things are changed and like runners hand over the lamp of life.

But ${ }^{4}$ some in opposition to this, ignorant of matter, believe that nature cannot without the providence of the gods in such nice conformity to the ways of men vary the seasons of the year and bring forth crops, ay and all the other things, which divine pleasure the guide of life prompts men to approach, escorting them in person and enticing them by her fondlings to continue their races through the arts of Venus, that mankind may not come to an end. Now when they suppose that the gods designed all things for the sake of men, they seem to me in all respects to have strayed most widely from true reason. For even if I did not know what first-beginnings are, yet this, judging by the very arrangements of heaven I would venture to affirm, and led by many other circumstances to maintain, that the nature of the world has by no means been made for us by divine power: so great are the defects with which it stands encumbered.

THE COURSE OF THE ATOMS

This ${ }^{5}$ point too herein we wish you to apprehend: when bodies are borne downward sheer through void by their own weights, at quite uncertain times and uncertain вpots they push themselves a little from their course;

'Munro's translation, p. 32.

s Ib., pp, 33-4. 


\section{SOURCE BOOK IN ANCIENT PHILOSOPHY}

you just and only just can call it a change of inclination. If they were not used to swerve, they would all fall down, like drops of rain, through the deep void, and no clashing would have been begotten nor blow produced among the first-beginnings: thus nature never would have produced aught.

But if haply any one believes that heavier bodies, as they are carried more quickly sheer through space, can fall from above on the lighter and so beget blows able to produce begetting motions, he goes most widely astray from true reason. For whenever bodies fall through water and thin air, they must quicken their descents in proportion to their weights, because the body of water and subtle nature of air cannot retard everything in equal degree, but inore readily give way, overpowered by the heavier: on the other hand empty void cannot offer resistance to anything in any direction at any time, but must, as its nature craves, continually give way; and for this reason all things must be moved and borne along with equal velocity though of unequal weights through the unresisting void. Therefore heavier things will never be able to fall from above on lighter nor of themselves to beget blows sufficient to produce the varied motions by which nature carries on things. Wherefore again and again I say bodies must swerve a little; and yet not more than the least possible; lest we be found to be imagining oblique motions and this the reality should refute. For this we see to be plain and evident, that weights, so far as in them is, cannot travel obliquely, when they fall from above, at least so far as you can perceive; but that nothing swerves in any case from the straight course, who is there that can perceive? 
THE UNCONCERNED GODS

For ${ }^{6}$ the nature of gods must ever in itself of necessity enjoy immortality together with supreme repose, far removed and withdrawn from our concerns; since exempt from every pain, exempt from all dangers, strong in its own resources, not wanting aught of us, it is neither gained by favors nor moved by anger.

\section{$*^{*} *$}

If ${ }^{7}$ you well apprehend and keep in mind these things, nature free at once and rid of her haughty lords is seen to do all things spontaneously of herself without the meddling of the gods. For I appeal to the holy breasts of the gods who in tranquil peace pass a calm time and an unruffled existence. Who can rule the sun, who hold in his hand with controlling force the strong reins of the immeasurable deep? Who can at once make all the different heavens to roll and warm with ethereal fires all the fruitful earths, or be present in all places at all times, to bring darkness with clouds and shake with noise the heaven's serene expanse, to hurl lightnings and often throw down his own temples, and withdrawing into the deserts there to spend his rage in practising his bolt which of ten passes the guilty by and strikes dead the innocent and unoffending?

THE NATURE OF MIND AND SOUL

And 8 now since I have shown what-like the beginnings of all things are and how diverse with varied shapes as they fly spontaneously driven on in everlasting motion, and how all things can be severally produced out of these, next after these questions the nature of the mind and

'Munro's translation, p. 43.

'Ib., p. $54 . \quad$ I Ib., p. 58. 
soul should methinks be cleared up by my verses and that dread of Acheron be driven headlong forth, troubling as it does the life of man from its inmost depths and overspreading all things with the blackness of death, allowing no pleasure to be pure and unalloyed.

Now ${ }^{9}$ I assert that the mind and the soul are kept together in close union and make up a single nature, but that the directing principle which we call mind and understanding, is the head so to speak and reigns paramount in the whole body. It has a fixed seat in the middle region of the breast: here throb fear and apprehension, about these spots dwell soothing joys; therefore here is the understanding or mind. All the rest of the soul disseminated through the whole body obeys and moves at the will and inclination of the mind. It by itself alone knows for itself, rejoices for itself, at times when the impression does not move either soul or body together with it. And as when some part of us, the head or the eye, suffers from an attack of pain, we do not feel the anguish at the same time over the whole body, thus the mind sometimes suffers pain by itself or is inspirited with joy, when all the rest of the soul throughout the limbs and frame is stirred by no novel sensation. But when the mind is excited by some more vehement apprehension, we see the whole soul feel in unison through all the limbs, sweats and paleness spread over the whole body, the tongue falter, the voice die away, a mist cover the eyes, the ears ring, the limbs sink under one; in short we often see men drop down from terror of mind; so that anybody may easily perceive from this that the soul is closely united with the mind,

-Munro's translation, pp. 60-2. 
and when it has been smitten by the influence of the mind, forthwith pushes and strikes the body.

This same principle teaches that the nature of the mind and soul is bodily; for when it is seen to push the limbs, rouse the body from sleep, and alter the countenance and guide and turn about the whole man, and when we see that none of these effects can take place without touch nor touch without body, must we not admit that the mind and the soul are of a bodily nature? Again you perceive that our mind in our body suffers together with the borly and feels in unison with it. When a weapon with a shudder-causing force has been driven in and has laid bare bones and sinews within the body, if it does not take life, yet there ensues a faintness and a lazy sinking to the ground and on the ground the turmoil of mind which arises, and sometimes a kind of undecided inclination to get up. Therefore the nature of the mind must be bodily, since it suffers from bodily weapons and blows.

I will now go on to explain in my verses of what kind of body the mind consists and out of what it is formed. First of all I say that it is extremely fine and formed of exceedingly minute bodies. That this is so you may, if you please to attend, clearly perceive from what follows: nothing that is seen takes place with a velocity equal to that of the mind when it starts some suggestion and actually sets it agoing; the mind therefore is stirred with greater rapidity than any of the things whose nature stands out visible to sight. But that which is so passing nimble must consist of seeds exceedingly round and exceedingly minute, in order to be stirred and set in motion by a small moving power. Thus water is moved and heaves by ever so small a force, 


\section{SOURCE BOOK IN ANCIENT PHILOSOPHY}

formed as it is of small particles apt to roll. But on the other hand the nature of honey is more sticky, its liquid more sluggish and its movement more dilatory; for the whole mass of matter coheres more closely, because sure enough it is made of bodies not so smooth, fine, and round. A breeze however gentle and light can force, as you may see, a high heap of poppy seed to be blown away from the top downward; but on the other hand Eurus itself cannot move a heap of stones. Therefore bodies possess a power of moving in proportion to their smallness and smoothness; and on the other hand the greater weight and roughness bodies prove to have, the more stable they are. Since then the nature of the mind has been found to be eminently easy to move, it must consist of bodies exceedingly small, smooth, and round. The knowledge of which fact, my good friend, will on many accounts prove useful and be serviceable to you. The following fact too likewise demonstrates how fine the texture is of which its nature is composed, and how small the room is in which it can be contained, could it only be collected into one mass: soon as the untroubled sleep of death has gotten hold of a man and the nature of the mind and soul has withdrawn, you can perceive then no diminution of the entire body either in appearance or weight: death makes all good save the vitai sense and heat. Therefore the whole soul must consist of very small seeds and be inwoven through the veins and flesh and sinews; inasmuch as, after it has all withdrawn from the whole body, the exterior contour of the limbs preserves itself entire and not a tittle of the weight is lost. Just in the same way when the flavor of wine is gone or when the delicious aroma of a perfume has been dispersed into the air or when the savor has 
left some body, yet the thing itself does not therefore look smaller to the eye, nor does aught seem to have been taken from the weight, because sure. enough many minute seeds make up the savors and the odor in the whole body of the several things. Therefore, again and again I say, you are to know that the nature of the mind and the soul has been formed of exceedingly minute seeds, since at its departure it takes away none of the weight.

\section{DISPELLING THE DREAD OF DEATH}

Death 10 therefore to us is nothing, concerns us not a jot, since the nature of the mind is proved to be mortal; and as in time gone by we felt no distress, when the Pœni from all sides came together to do battle, and all things shaken by war's troublous uproar shuddered and quaked beneath high heaven, and mortal men were in doubt which of the two peoples it should be to whose empire all must fall by sea and land alike, thus when we shall be no more, when there shall have been a separation of body and soul, out of both of which we are each formed into a single being, to us, you may be sure, who then shall be no more, nothing whatever can happen to excite sensation, not if earth shall be mingled with sea and sea with heaven. And even supposing the nature of the mind and power of the soul do feel, after they have been severed from our body, yet that is nothing to us who by the binding tie of marriage between body and soul are formed each into one single being. And if time should gather up our matter after our death and put it once more into the position in which it now is, and the light of life be given to us again, this result even would ${ }^{10}$ Munro's translation, pp. 77-8. 
concern us not at all, when the chain of our self-consciousness has once been snapped asunder. So now we give ourselves no concern about any self which we have been before, nor do we feel any distress on the score of that self. For when you look back on the whole past course of immeasurable time and think how manifold are the shapes which the motions of matter take, you may easily credit this too, that these very same seeds of which we now are formed, have of ten before been placed in the same order in which they now are; and yet we cannot recover this in memory: a break in our existence has been interposed, and all the motions have wandered to and fro far astray from the sensations they produced. For he whom evil is to befall, must in his own person exist at the very time it comes, if the misery and suffering are haply to have any place at all; but since death precludes this, and forbids him to be, upon whom the ills can be brought, you may be sure that we have nothing to fear after death, and that he who exists not, cannot become miserable, and that it matters not a whit whether he has been born into life at any other time, when immortal death has taken away his mortal life.

Therefore when you see a man bemoaning his hard case, that after death he shall either rot with his body laid in the grave or be devoured by flames or the jaws of wild beasts, you may be sure that his ring betrays a flaw and that there lurks in his heart a secret goad, though he himself declare that he does not believe that any sense will remain to him after death. He does not, methinks, really grant the conclusion which he professes to grant nor the principle on which he so professes, nor does he take and force himself root and branch out of life, but all unconsciously imagines something of self to survive. 
For when any one in life suggests to himself that birds and beasts will rend his body after death, he makes moan for himself, he does not separate himself from that self, nor withdraw himself fully from the body so thrown out, and fancies himself that other self and stands by and impregnates it with his own sense. Hence he makes much moan that he has been born mortal, and sees not that after real death there will be no other self to remain in life and lament to self that his own self has met death, and there to stand and grieve that his own self there lying is mangled or burnt. For if it is an evil after death to be pulled about by the devouring jaws of wild beasts, I cannot see why it should not be a cruel pain to be laid on fires and burn in hot flames, or to be placed in honey and stifled, or to stiffen with cold, stretched on the smooth surface of an icy slab of stone, or to be pressed down and crushed by a load of earth above.

Then ${ }^{11}$ there is Democritus who, when a ripe old age had warned him that the memory-waking motions of his mind were waning, by his own spontaneous act offered up his head to death. Even Epicurus passed away, when his light of life had run its course, he who surpassed in intellect the race of man and quenched the light of all, as the ethereal sun arisen quenches the stars. Wilt thou then hesitate and think it a hardship to die? Thou for whom life is well-nigh dead whilst yet thou livest and seest the light, who spendest the greater part of thy time in sleep and snorest wide awake and ceasest not to see visions and hast a mind troubled with groundless terror and canst not discover of ten what it is that ails thee, when besotted man thou art sore pressed on all

"Munro's translation, p. 82. 
sides with full many cares and goest astray tumbling about in the wayward wanderings of thy mind.

\section{NO DESIGNER OF NATURE}

But 12 in what ways yon concourse of matter founded earth and heaven and the deeps of the sea, the courses of the sun and moon, I will next in order describe. For verily not by design did the first-beginnings of things station themselves each in its right place by keen intelligence, nor did they bargain sooth to say what motions each should assume, but because the first-beginnings of things, many in number in many ways impelled by blows for infinite ages back and kept in motion by their own weights, have been wont to be carried along and to unite in all manner of ways and thoroughly to test every kind of production possible by their mutual combinations, therefore it is that, spread abroad through great time after trying unions and motions of every kind, they at length meet together in those masses which suddenly brought together become often the rudiments of great things, of earth, sea, and heaven and the race of living things.

No ${ }^{13}$ act is it of piety to be often seen with veiled head to turn to a stone and approach every altar and fall prostrate on the ground and spread out the palms before the statues of the gods and sprinkle the altars with much blood of beasts and link vow on to vow, but rather to be able to look on all things with a mind at peace.

12 Munro's translation, p. 126.

13 Ib., p. 145. 


\section{XX}

\section{EPICTETUS}

[Flourished about 90 A.D.]

\section{THINGS WHICH ARE IN OUR POWER}

SeEk ${ }^{1}$ at once, therefore, to be able to say to every unpleasing semblance, "You are but a semblance and by no means the real thing." And then examine it by those rules which you have; and first and chiefly, by this: whether it concerns the things which are within our own power, or those which are not; and if it concerns anything beyond our power, be prepared to say that it is nothing to you.

Men ${ }^{2}$ are disturbed not by things, but by the views which they take of things. Thus death is nothing terrible, else it would have appeared so to Socrates. But the terror consists in our notion of death, that it is terrible. When, therefore, we are hindered, or disturbed, or grieved let us never impute it to others, but to ourselves; that is, to our own views. It is the action of an uninstructed person to reproach others for his own misfortunes; of one entering upon instruction, to reproach himself; and of one perfectly instructed, to reproach neither others nor himself.

1 Ench. I. Higginson, II. 216. The selections from Epictetus are given in T. W. Higginson's translation. I quote from the twovolume edition, published in 1890 .

2 Ib., V. Higginson II. 218. 
Demand ${ }^{3}$ not that events should happen as you wish; but wish them to happen as they do happen, and you will go on well.

$\mathrm{Be}^{4}$ assured that the essence of piety toward the gods lies in this, to form right opinions concerning them, as existing; and as governing the universe justly and well. And fix yourself in this resolution, to obey them, and yield to them, and willingly follow them amidst all events, as being ruled by the most perfect wisdom. For thus you will never find fault with the gods, nor accuse them of neglecting you. And it is not possible for this to be effected in any other way than by withdrawing yourself from things which are not within our own power, and by making good or evil to consist only in those which are.

As ${ }^{5}$ it was fit, then, this most excellent and superior faculty alone, a right use of the appearances of things, the gods have placed in our own power; but all other matters they have not placed in our power. What, was it because they would not? I rather think that, if they could, they had granted us these too; but they certainly could not. For, placed upon earth, and confined to such a body and to such companions, how was it possible that, in these respects, we should not be hindered by things outside of us?

But what says Zeus? "O Epictetus, if it had been possible, I had made this little body and property of thine free, and not liable to hindrance. But now do not mistake; it is not thy own, but only a finer mixture of clay.

3 Ench. VIII. Higginson, II. 219.

- Ib., XXXI. Higginson, II. 229.

- Ub., XXXI. Disc. I. 1. Higginson, I. p. 1. 
Since, then, I could not give thee this, I have given thee a certain portion of myself; this faculty of exerting the powers of pursuit and avoidance, of desire and aversion, and, in a word, the use of the appearances of things. Taking care of this point, and making what is thy own to consist in this, thou wilt never be restrained, never be hindered; thou wilt not groan, wilt not complain, wilt not flatter any one. How, then? Do all these advantages seem small to thee? Heaven forbid! Let them suffice thee, then, and thank the gods."

But now, when it is in our power to take care of one thing, and to apply ourselves to one, we choose rather to take care of many and to encumber ourselves with many -body, property, brother, friend, child, and slave-and, by this multiplicity of encumbrances, we are burdened and weighed down. Thus, when the weather does not happen to be fair for sailing, we sit in distress and gaze out perpetually. Which way is the wind? North. What good will that do us? When will the west blow? When it pleases, friend, or when Eolus pleases; for Zeus has not made you dispenser of the winds, but Eolus.

What, then, is to be done?

To make the best of what is in our power, and take the rest as it occurs.

And how does it occur?

As it pleases God.

Do ${ }^{6}$ you therefore likewise, being sensible of this, consider the faculties you have, and after taking a view of them say, "Bring on me now, O Zeus, what difficulty thou wilt, for I have faculties granted me by thee, and powers by which I may win honor from every event"?

- Ench. XXXI. Disc. I. 6. Higginson, I. 26. 
THE BASENCE OF GOOD

God 7 is beneficial. Good is also beneficial. It should seem, then, that where the essence of God is, there too is the essence of good. What then is the essence of God -flesh? By no means. An estate? Fame? By no means. Intelligence? Knowledge? Right reason? Certainly. Here, then, without more ado, seek the essence of good. For do you seek that quality in a plant? No. Or in a brute? No. If, then, you seek it only in a rational subject, why do you seek it anywhere but in what distinguishes that from things irrational? Plants make no voluntary use of things, and therefore you do not apply the term good to them. Good, then, implies such use. And nothing else? If so, you may say that good and happiness and unhappiness belong to mere animals. But this you do not say, and you are right; for, how much soever they have the use of things, they have not the intelligent use, and with good reason, for they are made to be subservient to others, and not of primary importance. Why was an ass made? Was it as being of primary importance? No; but because we had need of a back able to carry burdens. We had need too that he should be capable of locomotion; therefore he had the voluntary use of things added, otherwise he could not have moved. But here his endowments end; for, if an understanding of that use had been likewise added, he would not, in reason, have been subject to us, nor have done us these services, but would have been like and equal to ourselves. Why will you not, therefore, seek the essence of good in that without which you cannot say that there is good in anything?

'Ench. XXXI. Disc. II. 8. Higginson, I. 132-4. 
What then? Are not all these likewise the works of the gods? They are; but not primary existences, nor parts of the gods. But you are a primary existence. You are a distinct portion of the essence of God, and contain a certain part of him in yourself. Why then are you ignorant of your noble birth? Why do not you consider whence you came? Why do not you remember, when you are eating, who you are who eat, and whom you feed? When you are in the company of women, when you are conversing, when you are exercising, when you are disputing, do not you know that it is the Divine you feed, the Divine you exercise? You carry a God about with you, poor wretch, and know nothing of it. Do you suppose I mean some god without you of gold or silver? It is within yourself that you carry him; and you do not observe that you profane him by impure thoughts and unclean actions. If the mere external image of God were present, you would not dare to act as you do; and when God himself is within you, and hears and sees all, are not you ashamed to think and act thus-insensible of your own nature, and at enmity with God?

Does ${ }^{8}$ any one fear things that seem evils indeed, but which it is in his own power to prevent?

No, surely.

If, then, the things independent of our will are neither good nor evil, and all things that do depend on will are in our own power, and can neither be taken away from us nor given to us unless we please, what room is there left for anxiety? But we are anxious about this paltry body or estate of ours, or about what Cæsar thinks, and not at all about anything internal. Are we ever anxious

- Ench. XXXI. Disc. II. 13. Higginson, I. 153-4. 
not to take up a false opinion? No; for this is within our own power. Or not to follow any pursuit contrary to nature? No, nor this. When, therefore, you see any one pale with anxiety, just as the physician pronounces from the complexion that such a patient is disordered in the spleen, and another in the liver, so do you likewise say, this man is disordered in his desires and aversions; he cannot walk steadily; he is in a fever. For nothing else changes the complexion, or causes trembling, or sets the teeth chattering.

\section{AS BOCRATES WOULD HAVE DONE}

When ${ }^{9}$ you are going to confer with any one, and especially with one who seems your superior, represent to yourself how Socrates or Zeno would behave in such a case, and you will not be at a loss to meet properly whatever may occur. ... When you do anything from a clear judgment that it ought to be done, never shrink from being seen to do it, even though the world should misunderstand it; for if you are not acting rightly, shun the action itself; if you are, why fear those who wrongly censure you?

Everything 10 has two handles: one by which it may be borne, another by which it cannot. If your brother acts unjustly, do not lay hold on the affair by the handle of his injustice, for by that it cannot be borne; but rather by the opposite, that he is your brother, that he was brought up with you; and thus you will lay hold on it as it is to be borne.

- Ench. XXXIII. and XXXV. Higginson, II. 234-5.

10 Ib., XLIII. Higginson, II. 238. 
Never ${ }^{11}$ proclaim yourself a philosopher; nor make much talk among the ignorant about your principles, but show them by actions. Thus, at an entertainment do not discourse how people ought to eat; but eat as you ought. For remember that thus Socrates also universally avoided all ostentation. And when persons came to him, and desired to be introduced by him to philosophers, he took them and introduced them; so well did he bear being overlooked. So if ever there should be among the ignorant any discussion of principles, be for the most part silent. For there is great danger in hastily throwing out what is undigested. And if any one tells you that you know nothing, and you are not nettled at it, then you may be sure that you have really entered on your work. For sheep do not hastily throw up the grass, to show the shepherds how much they have eaten; but, inwardly digesting their food, they produce it outwardly in wool and milk. Thus, therefore, do you not make an exhibition before the ignorant of your principles; but of the actions to which their digestion gives rise.

Whatever ${ }^{12}$ rules you have adopted, abide by them as laws, and as if you would be impious to transgress them; and do not regard what any one says of you, for this, after all, is no concern of yours. . . . Let whatever appears to be the best, be to you an inviolable law. And if any instance of pain or pleasure, glory or disgrace, be set before you, remember that now is the combat, now the Olympiad comes on, nor can it be put off; and that by one failure and defeat honor may be lost-or won. Thus Socrates became perfect, improving himself

"Ench. XLVI. Higginson, II. 239.

12 Ib., L. Higginson, II. 241. 
by everything, following reason alone. And though you are not yet a Socrates, you ought, however, to live as one seeking to be a Socrates.

\section{IN HARMONY WITH GOD AND HIS UNIVERSE}

All ${ }^{13}$ things serve and obey the [laws of the] universe: the earth, the sea, the sun, the stars, and the plants and animals of the earth. Our body likewise obeys the same, in being sick and well, young and old, and passing through the other changes decreed. It is therefore reasonable that what depends on ourselves, that is, our own understanding, should not be the only rebel. For the universe is powerful and superior, and consults the best for us by governing us in conjunction with the whole. And further, opposition, besides that it is unreasonable, and produces nothing except a vain struggle, throws us into pain and sorrows.

\section{$*^{*} *$}

Bring ${ }^{14}$ whatever you please, and I will turn it into good. Bring sickness, death, want, reproach, trial for life. All these, by the rod of Hermes, shall turn to advantage. "What will you make of death?" Why, what but an ornament to you; what but a means of your showing, by action, what that man is who knows and follows the will of Nature? "What will you make of sickness?" I will show its nature. I will make a good figure in it; I will be composed and happy; I will not beseech my physician, nor yet will I pray to die. What need you ask further? Whatever you give me, I will make it happy, fortunate, respectable, and eligible.

No, but, "take care not to be sick-it is an evil."

13 Fr. CXXXI. Higginson, II. 276.

10 Disc. III. $20 . \quad$ Higginson, II. 59. 
Just as if one should say, "Take care that the semblance of three being four does not present itself to you. It is an evil." How an evil, man? If I think as I ought about it, what hurt will it any longer do me? Will it not rather be even an advantage to me? If then I think as I ought of poverty, of sickness, of political disorder, is not that enough for me? Why then must I any longer seek good or evil in externals?

For ${ }^{15}$ all other pleasures substitute the consciousness that you are obeying God, and performing not in word, but in deed, the duty of a wise and good man. How great a thing is it to be able to say to yourself: "What others are now solemnly arguing in the schools, and can state in paradoxes, this I put in practice. Those qualities which are there discoursed, disputed, celebrated, I have made mine own. Zeus hath been pleased to let me recognize this within myself, and himself to discern whether he hath in me one fit for a soldier and a citizen, and to employ me as a witness to other men, concerning things uncontrollable by will. See that your fears were vain, your appetites vain. Seek not good from without; seek it within yourselves, or you will never find it. For this reason he now brings me hither, now sends me thither; sets me before mankind, poor, powerless, sick; banishes me to Gyaros; leads me to prison; not that he hates meHeaven forbid! for who hates the most faithful of his servants?-nor that he neglects me, for he neglects not one of the smallest things; but to exercise me, and make use of me as a witness to others. Appointed to such a service, do I still care where I am, or with whom, or what is said of me-instead of being wholly attentive to God and to his orders and commands?"

1b Disc. III. 24. Higginson, II. 107. 


\section{XXI}

\section{MARCUS AURELIUS}

[120-180 A.D.]

FOLLOW NATURE

Do ${ }^{1}$ thu therefore I say absolutely and freely make choice of that which is best, and stick unto it. Now, that they say is best which is most profitable. If they mean profitable to man as he is a rational man, stand thou to it and maintain it; but if they mean profitable as he is a creature only, reject it; and from this thy tenet and conclusion keep off carefully all plausible shows and colors of external appearance, that thou mayst be able to discern things rightly.

The end ${ }^{2}$ and object of a rational constitution is, to do nothing rashly, to be kindly affected toward men, and in all things willingly to submit unto the gods. Casting therefore all other things aside, keep thyself to these few, and remember withal that no man properly can be said to live more than that which is now present, which is but a moment of time. Whatsoever is besides either is already past, or is uncertain. The time therefore that any man doth live is but a little, and the place where he liveth is but a very little corner of the earth, and

${ }^{1}$ Marcus Aurelius, Meditations, III. 7. The extracts from Marcus Aurelius are, save for a few unimportant changes, given in the translation made by Casaubon early in the 17 th century.

2 Ib., III. 10. 
the greatest fame that can remain of a man after his death, even that is but little, and that too, such as it is whilst it is, is by the succession of silly mortal men preserved, who likewise shall shortly die, and even while they live know not what in very deed they themselves are: and much less can know one who long before is dead and gone.

Whatsoever ${ }^{3}$ is expedient unto thee, O World, is expedient unto me. Nothing can either be unseasonable unto me, or out of date, which unto thee is seasonable. Whatsoever thy seasons bear shall ever by me be esteemed as happy fruit and increase. O Nature! from thee are all things, in thee all things subsist, and to thee all tend. Could he say of Athens, Thou lovely City of Cecrops; and shalt not thou say of the World, Thou lovely City of God?

$\mathrm{He}^{4}$ that seeth the things that are now hath seen all that either was ever or ever shall be, for all things are of one kind and all like one unto another. Meditate often upon the connection of all things in the world, and upon the mutual relation that they have one unto another. For all things are after a sort folled and involved one within another, and by these means all agree well together. For one thing is consecuuent unto another by local motion, by natural conspiration and agreement, and by substantial union or the reluction of all substances into One.

Fit and accommodate thyself to that estate and to those occurrences which by the destinies have been annexed unto thee; and love those men whom thy fate

'Marcus Aurelius, Meditations, IV. 19.

- Ib., VI. 34-5. 
it is to live with; but love them truly. An instrument, a tool, an utensil, whatsoever it be, if it be fit for the purpose it was made for it is as it should be, though he perchance that made and fitted it be out of sight and gone. But in things natural, that power which hath framed and fitted them is and abideth within them still. For which reason she ought also the more to be respected, and we are the more obliged (if we may live and pass our time according to her purpose and intention) to think that all is well with us and according to our own minds. After this manner also ... He that is all in all doth enjoy his happiness.

$$
*^{*} *
$$

We ${ }^{5}$ all work to one effect, some willingly and with a rational apprehension of what we do, others without any such knowledge.

If ${ }^{6}$ so be that the gods have deliberated in particular of those things that should happen unto me, I must stand to their deliberation, as discreet and wise. For that a god should be an imprudent god is a thing hard even to conceive. And why should they resolve to do me hurt? For what profit either unto them or the universe (which they specially take care for) could arise from it? But if so be that they have not deliberated of me in particular, certainly they have of the whole in general, and those things which in consequence and coherence of this general deliberation happen unto me in particular I am bound to embrace and accept of. But if so be that... they have not indeed, either in general or particular, deliberated of any of those things that happen unto us in this world, yet God be thanked

- Marcus Aurelius, Meditations, VI. 37.

- Ib., VI. 39. 
that of those things that concern myself it is lawful for me to deliberate myself, and all my deliberation is but concerning that which may be to me most profitable. Now that unto every one is most profitable which is according to his own constitution and nature. And my nature is to be rational in all my actions and, as a good and natural member of a city and commonwealth, toward my fellow-members ever to be sociably and kindly disposed and affected. My city and country as I am Antoninus is Rome; as a man, the whole world. Those things therefore that are expedient and profitable to those cities are the only things that are good and expedient for me.

$$
*^{*}{ }^{*}
$$

Either ${ }^{7}$ with Epicurus we must fondly imagine the atoms to be the cause of all things, or we must needs grant a nature. Let this then be thy first ground, that thou art part of that universe which is governed by nature. Then, secondly, that to those parts that are of the same kind and nature as thou art thou hast relation of kindred. For of these if I shall always be mindful, first, as I am a part, I shall never be displeased with anything that falls to my particular share of the common chances of the world. For nothing that is behooveful unto the whole can be truly hurtful to that which is a part of it. For this being the common privilege of all natures, that they contain nothing in themselves that is hurtful unto them, it cannot be that the nature of the universe (whose privilege beyond other particular natures is that she cannot against her will by any higher external cause be constrained) should beget anything and cherish it in her bosom that should

' Marcus Aurelius, Meditations, X. 6. 
tend to her own hurt and prejudice. As then I bear in mind that I am a part of such an universe I shall not be displeased with anything that happens. And as I have relation of kindred to those parts that are of the same kind and nature that I am, so I shall be careful to do nothing that is prejudicial to the community, but in all my deliberations shall they that are of my kind ever be; and the common good shall be that which all my intentions and resolutions shall drive unto, just as that which is contrary unto it I shall by all means endeavor to prevent and avoid. These things once so fixed and concluded, as thou wouldest think him an happy citizen whose constant study and practice were for the good and benefit of his fellow-citizens, and the carriage of the city such toward him that he were well pleased with it - so must it needs be with thee that thou shalt live a happy life.

Ever ${ }^{8}$ consider and think upon the world as being but one living substance and having but one soul; and how all things in the world are terminated into one sensitive power, and are done by one general motion, as it were, and by the deliberation of that one soul; and how all things that are coneur in the cause of one another's being, and by what manner of connection and concatenation all things happen.

What art thou, that better and divine part excepted, but as Epictetus well said, a wretched soul appointed to carry a carcass up and down?

To suffer change can be no hurt; as no benefit it is by change to attain to being. The age and time of the world is as it were a flood and swift current, consisting

- Marcus Aurelius, Meditations, IV. 33-4. 
of the things that are brought to pass in the world. For as soon as anything hath appeared and is passed away another succeeds, and that also will pass presently out of sight.

They ${ }^{9}$ will say commonly, Meddle not with many things if thou wilt live cheerfully. Certainly there is nothing better than for a man to confine himself to necessary actions; to such and so many only as reason in a creature that knows itself born for society will command and enjoin. This will not only procure that cheerfulness, which from the goodness, but that also which from the paucity of actions doth usually proceed. For since it is so, that most of those things which we either speak or do are unnecessary, if a man shall cut them off, it must needs follow that he shall thereby gain much leisure and save much trouble; and therefore at every action a man must privately by way of admonition suggest unto himself, What? may not this that now I go about be of the number of unnecessary actions? Neither must he accustom himself to cut off actions only, but also thoughts and imaginations that are unnecessary; for so will unnecessary consequent actions the better be prevented and cut off.

THE HARMONY OF THE UNIVERSE

All ${ }^{10}$ parts of the world (all things I mean that are contained within the whole world) must of necessity at some time or other come to corruption. Alteration I should say, to speak truly and properly; but that I may be the better understood I am content at this time to use that more common word. Now, say I, if so be that this

- Marcus Aurelius, Meditations, IV. 20.

$10 \mathrm{Ib} .$, X. 7. 
be both hurtful unto them and yet unavoidable, would not, thinkest thou, the whole itself be in a sweet case, all the parts of it being subject to alteration-yea and by their making the whole itself fitted for corruption as consisting of things different and contrary? And did nature then either of herself thus project and purpose the affliction and misery of her parts, and therefore of purpose so made them, not only that haply they might, but of necessity that they should fall into evil; or did not she know what she did when she made them? For to say either of these things is equally absurd. But to let pass nature in general, and to reason of things particular according to their own particular natures, how absurd and ridiculous is it, first to say that all parts of the whole are by their proper natural constitution subject to alteration, and then when any such thing doth happen as when one doth fall sick and dieth, to take on and wonder as though some strange thing had happened? Though this besides might move us not to take on so grievously when any such thing doth happen, that whatsoever is dissolved is dissolved into those things whereof it was compounded. For every dissolution is either a mere dispersion of the elements into those elements again whereof everything did consist, or a change of that which is more solid into earth, and of that which is pure and subtile or spiritual into air. So that by this means nothing is lost, but all is resumed again into those rational generative seeds of the universe, and this universe is either after a certain period of time to be consumed by fire or by continual changes to be renewed, and so forever to endure. Now, that solid and spiritual that we speak of, thou must not conceive it to be that very same which at first was when thou wert 
born. For alas! all this that now thou art in either kind, either for matter of substance or of life, hath but two or three days ago, partly from meats eaten and partly from air breathed in, received all its influx, being the same then in no other respect than a running river, maintained by the perpetual influx and new supply of waters, is the same. That therefore which thou hast since received, not that which came from thy mother, is that which comes to change and corruption. But suppose that that for the general substance and more solid part of it should still cleave unto thee never so close, yet what is that to the proper qualities and affections of it by which persons are distinguished, which certainly are quite different?

Whatsoever ${ }^{11}$ doth happen in the world is, in the course of nature, as usual and ordinary as a rose in the spring and fruit in summer. Of the same nature is sickness and death, slander and lying in wait, and whatsoever else ordinarily doth unto fools use to be occasion either of joy or sorrow. That, whatsoever it is that comes after, doth always very naturally, and as it were familiarly, follow upon that which was before. For thou must consider the things of the world not as a loose independent number consisting merely of necessary events, but as a discreet connection of things orderly and harmoniously disposed. There is then to be seen in the things of the world, not a bare succession, but an admirable correspondence and affinity.

\section{$*^{*} *$}

As ${ }^{12}$ we say commonly, the physician hath prescribed unto this man riding; unto another, cold baths; unto a

${ }^{11}$ Marcus Aurelius, Meditations, IV. 36.

12 Ib., V. 8. 


\section{SOURCE BOOK IN ANCIENT PHILOSOPHY}

third, to go barefoot: so it is alike to say, The nature of the universe hath prescribed unto this man sickness or blindness or some loss or damage or some such thing. For as there, when we say of a physician that he hath prescribed anything, our meaning is that he hath appointed this for that, as subordinate and conducing to health; so here, whatsoever doth happen unto any is ordained unto him as a thing subordinate unto the fates, and therefore do we say of such things that they do $\sigma \nu \mu \beta a i \nu \epsilon \iota \nu$, that is, happen, or fall together; as of square stones, when either in walls or pyramids in a certain position they fit one another, and agree as it were in an harmony, the masons say that they do $\sigma v \mu \beta a i \nu \epsilon \nu$; as if thou shouldst say, fall together. So that in general though the things be divers that make it, yet the consent or harmony itself is but one. And as the whole world is made up of all the particular bodies of the world, one perfect and complete body of the same nature as particular bodies: so is the destiny of particular causes and events one general one, of the same nature that particular causes are. What I now say even they that are mere idiots are not ignorant of, for they say commonly roviro $\check{\epsilon} \phi \epsilon \rho \epsilon \nu$ aUं $\hat{\omega}$, that is, This his Destiny hath brought upon him. This therefore is by the Fates properly and particularly brought upon this, as that unto this in particular is by the physician prescribed. These therefore let us accept of in like manner as we do those that are prescribed unto us by our physicians. For them also in themselves shall we find to contain many harsh things, but we nevertheless, in hope of health and recovery, accept of them. Let the fulfilling and accomplishment of those things which the common nature hath determined be unto thee as thy health. Accept them, 
and be pleased with whatsoever doth happen though otherwise harsh and unpleasing, as tending to that end, to the health and welfare of the universe, and to Jove's happiness and prosperity. For this, whatsoever it be, would not have been produced had it not conduced to the good of the universe. For neither doth any ordinary particular nature bring anything to pass that is not agreeable and subordinate to whatsoever is within the sphere of its own proper administration and government. For these two considerations then thou must be well pleased with anything that doth happen unto thee. First, because for thee properly it was brought to pass and unto thee it was prescribed, and from the very beginning, by the series and connection of the first causes, it hath ever had a reference unto thee. And secondly, because the good success and perfect welfare, and indeed the very continuance of Him that is the Administrator of the whole, doth in a manner depend on it. For the whole (because whole, therefore entire and perfect) is maimed and mutilated if thou shalt cut off anything at all whereby the coherence and contiguity (as of parts, so) of causes is maintained and preserved. Of which certain it is that thou dost (as much as lieth in thee) cut off, and in some sort violently take somewhat away, as often as thou art displeased with anything that happeneth.

Thou ${ }^{13}$ must comfort thyself in the expectation of thy natural dissolution and in the meantime not grieve at the delay, but rest contented in these two things: First, that nothing shall happen unto thee which is not according to the nature of the universe. Secondly, that it is in

13 Marcus Aurelius, Meditations, V. 10. 


\section{SOURCE BOOK IN ANCIENT PHILOSOPHY}

thy power to refrain from doing anything contrary to thine own proper god and inward spirit. For it is not in any man's power to constrain thee to transgress against him.

MAN's INSIGNIFICANCE AND HIS GRANDEUR

What ${ }^{14}$ a small portion of vast and infinite eternity it is that is allowed unto every one of us, and how soon it vanisheth into the general age of the world. Of the common substance and of the common soul also, what a small portion is allotted unto us, and in what a little clod of the whole earth it is that thou dost crawl. After thou shalt rightly have considered these things with thyself fancy not anything else in the world any more to be of any weight and moment, but this: to do that only which thine own nature doth require, and to conform thyself to that which the common nature doth afford.

What is the present estate of my understanding? For herein lieth all indeed. As for all other things they are without the compass of mine own will, and if without the compass of my will then are they as dead things unto me and as it were mere smoke.

To stir up a man to the contempt of death this among other things is of good power and efficacy, that even they who esteemed pleasure to be happiness and pain misery did nevertheless many of them contemn death as much as any. And can death be terrible to him to whom that only seems good which in the ordinary course of nature is seasonable? to him to whom, whether his actions be many or few, so they be all good, is all one; and who, whether he behold the things of the world being always the same, either for many years or for few years only, is

14 Marcus Aurelius, Meditations, XII. 25. 
altogether indifferent? O man! as a citizen thou hast lived and conversed in this great City the World. Whether just for so many years or no, what is it unto thee? Thou hast lived (thou mayst be sure) as long as the laws and orders of the city required; which may be the common comfort of all. Why then should it be grievous unto thee if [not a tyrant nor an unjust judge, but] the same nature that brought thee into the world doth now send thee out of it? It is as if the prætor should fairly dismiss him from the stage whom he had taken in to act a while. Oh, but the play is not yet at an end, there are but three acts yet acted of it? Thou hast well said, for in matter of life three acts is the whole play. Now to set a certain time to every man's acting belongs unto him only who as first he was the cause of thy composition so now is he the cause of thy dissolution. As for thyself, thou hast to do with neither. Go thy ways then well pleased and contented, for so is He that dismisseth thee.

\section{$*^{*} *$}

To ${ }^{15}$ live happily is an inward power of the soul when she is affected with indifference toward those things that are by their nature indlifferent. To be thus affected she must consider all worldly objects, both divided and whole, remembering withal that no object can of itself beget any opinion in us, neither can come to us, but stands without, still and quiet; but that we ourselves beget, and as it were print in ourselves, opinions concerning them. Now it is in our power not to print them; and if they creep in and lurk in some corner, it is in our power to wipe them off. Remembering, moreover, that this care and eircumspection of thine is to continue but for a while, and then thy life will be at an ${ }^{16}$ Marcus Aurelius, Meditations, XI. 15. 
end. And what should hinder but that thou mayst do well with all these things? For if they be according to nature, rejoice in them and let them be pleasing and acceptable unto thee. But if they be against nature, seek thou that which is according to thine own nature, and whether it be for thy credit or no, use all possible speed for the attainment of it; for no man ought to be blamed for seeking his own good and happiness.

Cast ${ }^{16}$ away from thee opinion and thou art safe. And what is it that hinders thee from casting it away? When thou art grieved at anything hast thou forgotten that all things happen according to the nature of the universe, and that him only it concerns who is in fault, and moreover that what is now done is that which from ever hath been done in the world and will ever be done, and is now done everywhere? Hast thou forgotten how closely all men are allied one to another by a kindred, not of blood nor of seed, but of the same mind? Thou hast also forgotten that every man's mind partakes of the Deity and issueth from thence, and that no man can properly call anything his own, no, not his son, nor his body, nor his life, for they all proceed from that One who is the giver of all things: that all things are but opinion; that no man lives properly but that very instant of time which is now present, and therefore that no man, whensoever he dieth, can properly be said to lose any more than an instant of time.

How ${ }^{17}$ easy a thing it is for a man to put off from him all turbulent adventitious imaginations, and presently to be in perfect rest and tranquillity!

10 Marcus Aurelius, Meditations, XII. 19.

17 Ib., V. 2. 
Think thyself fit and worthy to speak or to do anything that is according to nature, and let not the reproach or report of some that may ensue upon it ever deter thee. If it be right and honest to be spoken or done, undervalue not thyself so much as to be discouraged from it. As for them, they have their own rational overruling part and their own proper inclination, which thou must not stand and look about to take notice of, but go on straight whither both thine own particular and the common nature do lead thee; and the way of both these is but one. 


\section{XXII}

\section{PLOTINUS $\dagger$}

[205-270 A.D.]

THE SOUL

ARE ${ }^{1}$ we all immortal? Or do we utterly perish? Or, a third alternative, does part of us pass way into dissolution and destruction while part-the real selfis everlasting? These are questions which we might naturally investigate and learn to answer, after the following fashion.

Man, we might say, is not something simple, but has within him a soul. He has also a body attached to him, it may be as an instrument, it may be in some other capacity. Let us then distinguish the soul from the body and have a look at the nature and character of them both. Evidently a body which is composite cannot in reason be lasting. Moreover our senses perceive its dissolution and disintegration and liability to corruption of every sort, the reversion of its ingredients each to its proper nature, the destruction of one part by another, and their change and corruption into things other than

${ }^{1}$ Plotinus, Enneads, IV. 7, $\$ 1,456$ (C. p. 843; V. II. p. 120). The chapters referred to are those of the Creuzer text. Where it seemed advisable to do so page references to this text-abbroviated as C.-are added, and parallel references to the Volkmann text in the Teubner series-abbreviated as V.

† Dr. B. A. G. Fuller has made the selection and the translation ithe passages from Plotinus. 
they were. This is particularly noticeable whenever the soul, which puts them in accord, is not present in a mass of matter. Then, too, though each thing in the process of generation becomes an individual, it is not an unit, since it can be resolved into form and matter. Hence even the simple bodies are compound. Again it is a fact that since whatever is corporeal has magnitude and can be divided and broken up into bits, it must for this reason also be subject to corruption.

It follows that if the body be a part of us, the whole of us is not immortal. And if it be an instrument, it must be given to us for a certain time as such. But the dominant part and the essential man himself would bear the same relation to the body as form to matter, or as a man to the instrument he uses.

In either case, however, the soul is the man's real self.

What ${ }^{2}$ now is the nature of the soul? If the soul be corporeal, it can be wholly disintegrated, seeing that everything corporeal is, as we have said, composite. If it be not corporeal, but of another nature, we must investigate this, too, either after the old or after some other fashion. In the first place [if the soul be corporeal] we must inquire into what this body which they call the soul can be resolved. For since life is necessarily at hand in the soul, this body-which the soul is-must, if it consist of two or more bodies, have life innate in both or each, or one only, or none of these bodies. If life belongs to one of them this body would be the soul. But what kind of body would that be which was naturally animate? For fire, and water, and air, and earth are naturally inanimate, and whenever any one of

2 Plotinus, Enneads, IV. 7, § 2. 
them has soul present in it it has possessed itself of life as of something imported from without. But, besides fire, air, water, and earth there are no bodies. And even such as believe that there are elements different from those enumerated, call them bodies, not souls, and ascribe no life to them.

If, however, no one of the bodies [which make up the soul] is possessed of life, it is absurd to think that their conjunction has created life. And if each of them is animate, then one of them is sufficient for our purpose. It is peculiarly impossible, however, that a combination of bodies should produce life or that intellect should be produced by that which is without it. Moreover, it is not maintained that life is produced by any random commingling. There must be then a principle which is directive and causes the mixture. But this would take the place of the soul. In fine, there could be no composite, nor even any simple body in being were there not soul in the universe, if indeed it be a seminal reason entering into matter which makes a body, and a seminal reason can come from nowhere except from soul. . . .

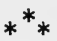

For ${ }^{3}$ there could be no body were there no psychic power existent, since the corporeal is in flux and its nature in motion, and would be immediately destroyed if there were nothing but the corporeal. This would be true even if one gave the name "soul" to one of these bodies, since this would fare like the others, seeing that they would be of one matter. Or rather, there would be no generation at all, but all things would remain mere matter for the lack of anything to give them form.

' Plotinus, Enneads, IV. 7, § 3, 458 C (C. p. 847, 1. 15 et seq.; V. II. $122,1.17$ et seq.). 
Perhaps, too, there would not be even any matter, and this world-all would be dissolved, if one trusted for its existence to the conjunction of the corporeal, and gave to this the place of soul, at any rate, so far as the name went, ascribing it to air and to spirits which are most dissoluble and without any unity of themselves. For, I ask you, in view of the divisibility of all corporeal things, will not the man who confides this universe to any one of them, thereby make it unintelligent and borne about at random? What ordering principle is there in animal spirits which owe their order to soul, or what reason or what intelligence? But if soul exists, then all these things are ministrant to her constitution of the world and of the individual living being, in that one power proceeding from another contributes to the whole. 'Were she, however, not present in things, they would have no being at all, let alone an orderly existence. ... .

That ${ }^{4}$ if the soul were corporeal there would be no sensation nor thought nor undertaking nor virtue nor anything beautiful is clear also from the following considerations: If one thing is to perceive another it must be one, and grasp everything in the same operation, even though the incoming perception be multiple and enter through several senses, or there be several qualities of one object, or through the oneness there appear a variety, as in the case of a face. For one operation does not perceive a nose, another the eyes, but the same operation perceives all things together. Moreover, if one sensation come through the eyes, another through the hearing,

4 Plotinus, Enneads, IV. 7, §6, 461 A (C. p. 853, 1. 3 et seq.; V. II. $126,1.11$ et seq.). 


\section{SOURCE BOOK IN ANCIENT PHILOSOPHY}

there must be some one thing to which both come. Otherwise, if they did not come both together to this same something, how could one say that the perceptions were different? This something must be like a centre to which the sensations from all sides penetrate like lines converging from the circumference of a circle. Such then is the apperceptive faculty - a real unity. . . .

\section{$*^{*} *$}

We ${ }^{5}$ may also see the same thing from the case of pain and the sensation of pain. Whenever a man says that his finger hurts, the pain naturally has to do with his finger, but the sensation of pain, it will of course be agreed, has to do with the ruling faculty. Although the part hurt is different from it, the ruling faculty perceives the animal spirits and the whole soul suffers the same pain. Now how does this happen? By transmission, it is said, in that first the animal spirits which are connected with the finger suffer and hand on their suffering to the next part in turn, and this to still another, and so on till it reaches the ruling faculty. Necessarily then, if the part hurt first feels, the sensation of the second part will be another sensation-in case, I mean, sensation is by transmission,-and that of the third still another. In this way there will be many, indeed innumerable sensations of the one pain generated, and finally the ruling faculty will feel them all, and its own pain besides. The truth is that on this theory each one of these parts will not feel the pain in the finger, but the part next the finger will feel that the palm of the hand hurts, and the third that there is a pain somewhere else higher up.

- Plotinus, Enneads, IV. 7, $\S 7,462$ A (C. p. $855,1.9$ et seq.; V. II. $128,1.3$ et seq.). 
So there will be many pains, and the ruling faculty will not perceive the pain in the finger but the pain in itself. Only of this last will it be conscious, and will pay no heed to the other pains, and will not understand that it is the finger which is hurting. A sensation then of pain in the finger cannot be generated by transmission, nor can any one part of the body - which is an extended mass-be aware of another's suffering, since in every extended object when one part is in one place the others are in other places. Hence, I say it is necessary to conceive the perceiving faculty as throughout identical with itself. But such a conception is not appropriate to body but to some other form of being.

\section{$*^{*} *$}

That ${ }^{6}$ thought also is impossible if the soul be a body of any sort is to be proved as follows. If sensation be the soul's perceiving sensible objects with the help of the body, then thought also cannot be comprehension through the instrumentality of the body, since in that case it will be the same as sensation. If then thought be comprehension of objects without the aid of the body, surely that which thinks has even a stronger claim to not being body. Again, if sensation be of sensible objects, thought is of intelligible objects. If our opponents will not grant this, they must at least grant that there are thoughts of some intelligible objects, and apprehensions of things which have no extension. But then how can that which has extension think that which has not, and with its divisible nature think the indivisible? Do you say, with some indivisible portion of itself? In that case, however, that which thinks will not be a body. For under these circumstances there

- Plotinus, Enneads, IV. 7, §8. 
will be no need of the whole for the contact of thought with its object, but a single part will suffice.

Moreover, if it be conceded that the most abstract thoughts are of things in every respect pure of the corporeal, what thinks, also, by virtue of being or becoming pure of the corporeal, attains knowledge of them. And if it be asserted that thoughts are of forms inhering in matter, then the thoughts of the forms are attained only by abstracting the bodies, and it is intellect which does the abstracting. There is, for instance, no residuum of flesh or of matter of any sort in the abstractions of a circle, a triangle, a line, or a point. The soul then, when at such work, must of necessity abstract herself from the body. It follows that she herself cannot be body. I think also that the beautiful and the right are not extended things, and that hence the thought of them cannot be extended. So, when these things meet her, she will receive them with the indivisible part of herself, and they will lie in her indivisible self. . . .

Again there is the question whether the soul grasp the maxims of virtue and other intelligible objects as things eternal, or virtue be generated and must needs perish again. But what destroys it, and whence does it spring? For this again would abide. Virtue then must belong to the eternal and abiding, as do geometrical entities. But if it belongs to the eternal and the abiding, it is not corporeal. And that in which it resides must also be incorporeal, and cannot be a body. For all corporeal nature abides not, but is in flux. . . . But if the soul be neither body nor any property of body but rather active and creative, and possessed of much, both in and of herself, she must be a separate essence from bodies. What kind of an essence then? Clearly she must be that 
which we call real essence. For the corporeal might all be called a process, but not an essence, seeing that it is in a process of generation and corruption and never for a moment really is anything, but by its participation in being is kept in existence to the degree that it does participate in it. ...

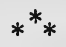

There ${ }^{7}$ is then another nature that of itself possesses all real being such as is neither generated nor destroyed. For all things else would pass away and never again come into existence, if this were destroyed, since this it is which preserves them and this universe, keeping them in existence and in order through the mediation of soul. . . .

That 8 the soul is akin to the diviner and eternal nature is made clear by the facts that she has been proven to be incorporeal, has neither form nor color, and is intangible. But there are other proofs as well. And since we are agreed that everything divine and possessed of real being enjoys a good and rational life, our next task is to start with our own soul and inquire what her nature is. Let us take then a soul-not one sunk in the body which has laid hold of irrational desires and emotions and received into herself other passions, but one which has sloughed these all off and has as little commerce as possible with the body. Such an one shows clearly that evil is a foreign accretion on the soul, and that in the purified soul everything that is best, wisdom and every other virtue, inheres and is native.

' Plotinus, Enneads, IV. 7, 463 A (C. p. 863, l. 13; V. II. 136, l. 12 et seq.).

I Ib., $\$ 14,464$ A (C. p. $865,1.1$; V. II. 137, 1. 13 et seq.). 
... But ${ }^{9}$ in investigating the nature of anything one must regard it in its purity, since any accretion always stands in the way of knowing that to which it is superadded. Abstract then in investigating, or rather let him who abstracts look at himself, and he will be persuaded that he is immortal when he sees himself on the intelligible and pure plane. For he will see his intellect regarding not any sensible or mortal thing, but with its eternal self thinking the eternal, and all things which exist in the intelligible world. Nay, he will see his intellect itself become intelligible and luminous, resplendent with the truths proceeding from the good which illuminates intelligible objects with truth. ...

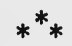

Again ${ }^{10}$ what sane man could raise a doubt as to the immortality of such a nature, possessed as it is of a self-originated life that cannot be destroyed? . . . For either its essence is life or else life is something superadded to matter. In the first case, this essence will be either self-animated-which is just what we are looking for and we agree is immortal-or may be analyzed as a compound and the process repeated till an imperishable self-moved element be reached which cannot be liable to death. In the second case, if our opponents say that life be a property superadded to matter, they will be forced to confess that the source of this property of life in matter must itself be immortal, since it cannot be subject to the opposite of what it imparts. There is then one nature whose characteristic activity is life.

- Plotinus, Enneads, IV. 7, 464 E.

${ }^{10}$ Ib., $\$ 15,465$ (C. p. $867,1.11$ et seq.; V. II. 139, 1. 10 et seq.). 
Again, ${ }^{11}$ if it be said that all soul is corruptible, then all things would have perished long ago. But if it be said that some soul perishes, other not, as for instance that the world-soul is immortal but our souls mortal, the reason for this distinction must be given. For both are principles of motion, both are self-animated, and both grasp the same objects with the same faculty, thinking both heavenly objects and those which transcend the heavens, and both seek all essential being and mount up to the first principle of all things. Also her ability to classify each thing of herself because of the notion innate within her-an ability produced by reminiscence of the intelligible-gives our soul an existence prior to the body, and since she is in enjoyment of eternal principles, shows that she herself is also eternal.

Finally, everything dissoluble has been produced by combination, and is dissolved after the same fashion in which it was combined. But the soul is single and simple, a nature whose characteristic activity consists in living. She cannot then be destroyed by dissolution. But, do you say, she might be destroyed by being divided and broken up? However, she has no mass or quantity, as has been shown. Or, do you say, by a process of alteration she might pass into corruption? Alteration, however, in destroying, though it takes away the form leaves the matter. It is a composite being then, which is liable to it. But if the soul cannot be destroyed after any of these fashions, she must necessarily be immortal. . . .

We ${ }^{12}$ speak of the soul of each individual as one, because she is present in her entirety throughout the 1 Plotinus, Enneads, IV. 7, § 16.

12 Ib., IV. 9, § 1, 477 (C. p. 888; V. II. 153). 
body, and is really one in that she does not have one part here, another there. In sensitive beings, too, the same is true of the sensitive soul, and in plants the whole soul is present throughout in every part. Now are my soul and your soul one, and all souls one in the same way? And in the universe is one soul present in all things, not divided as a thing which has mass is divided, but everywhere the same? For why should this soul of mine be one but the soul in the universe not one? There is no question there either of mass or body. Moreover, if your soul and mine proceed from the world-soul, and it is one, then ours should be one also. And if the world-soul and my soul are derived from one soul, then again they should be one. What sort of a soul would this one then be?

First, however, we must decide whether it be indeed correct to call all souls one, in the sense that the soul of a single individual is one. Now it involves a real absurdity if my soul and the soul of any other person are one. For in that case when I perceived, he too would have to perceive, and if I were good, would have to be good, and if I desired, would also have to desire. And in general we should share the same sensations with one another and with the universe, so that whenever I were affected in any wise, the universe would share in my sensation. Again, if all souls be one, how can the rational be different from the irrational soul, or the soul in animals different from that in plants? But on the other hand if we do not posit this unity, the universe will not be one, and no single source of souls will have been found.

\section{$*^{*} *$}

In ${ }^{13}$ the first place then, if my soul and the soul of another man be one, it will not follow that both are 1s Plotinus, Enneads, IV. 9, \$2. 
reciprocally identical. For although the same thing may be present in both, it will not have the same properties in the two cases. Thus humanity may be present in me who am in motion, and in you who are not in motion. In me humanity will be moved, in you at rest, and still there is nothing absurd or paradoxical in the fact that it is the same humanity which is in you and me. It is not necessary, then, that when I perceive something, another man should have exactly the same experience. For that matter, too, given a single body, one hand does not perceive what the other feels, but rather the soul which resides in the whole body. And had you to know my feelings our bodies would have to merge into one another, and we two become a single individual. Thus knitted together both souls would have identical perceptions.

We ought also to note the many things of which the whole is unconscious, even in the case of one and the same body. This is the more noticeable the bigger the body is. For instance, there are huge sea-monsters in which no perception whatever of anything experienced by a part reaches the whole, because of the comparative slightness of the motion excited. We nay conclude that no clearly defined experience need be received by the whole organism when one particular part is affected. But that it should be affected sympathetically, though there is not necessarily any definite sensation, is not absurd and cannot be denied. It will not be absurd then that the same thing should be virtuous in me, vicious in you, seeing that it can exist in one man in a state of motion, in another at rest. For after all we do not call the soul one in a sense which altogether excludes plurality. Such unity is to be attributed to the nature which is 
better than soul. Soul, on the contrary, we call oneand-many, and say that it participates in the divisible corporeal nature, and in the indivisible as well, so that again it is one. And just as in my case, whatever is generated by the ruling faculty communicates something to the part, in spite of the fact that the affection of the part does not prevail over the whole; so everything which the universe communicates to the particular is quite manifest because of our manifold sympathetic relations with the universe, whereas we do not know for certain whether our experiences are contributed to the worldall or not. . . .

The ${ }^{14}$ question now is, After what fashion is the one essence in the many souls? For either the one essence in them all is a sum total, or else the many are derived from the whole and single essence without disturbing its wholeness or unity. It, however, is one, and the many souls are related to it as the one unity which gives itself to the many, and at the same time does not give itself. For it is able to give itself to all, and yet to remain one. It can penetrate simultaneously all things, and not be severed at all from any one of them. It is one and the same thing in many.

There should be no difficulty about believing this. A science exists as a whole, and is related to its parts in such wise that its wholeness is not impaired by the derivation of the parts from it. A seed also is a whole, and the parts are derived from it into which it naturally divides itself, and each of these is a whole, and remains a whole.

But the whole is not diminished-it is matter which

14 Plotinus, Enneads, IV. 9, § 5, 480 A (C. p. 894; V. II. 157). 
divides it up-and all the parts are one. Perhaps, however, it will be said that in the case of a science the part is not the whole. It is true, to be sure, in this case, that the part which we are using is at hand and is emphasized. Still, the other parts also follow, latent and potential, and are all contained in the part in question. It is in this sense that one speaks of the whole science and of a part of it. But in the soul all the parts coexist in their actuality. In the case of a science, to revert, each part is ready to which you may wish to put your hand. The readiness for use lies in the part, but it gets its efficacy from its contiguity to the whole. One cannot regard it as empty of the other propositions. Were it, it would not hold either in practice or in theory, but would be mere child's prattle. If it holds theoretically, it is because it contains all the parts potentially. A thinker in thinking, I say, deduces the other parts by implication. A geometer in his analysis makes clear how the one part or proposition contains all the other propositions through which the analysis has proceeded, and also all the consequent propositions which follow from it. These things, however, gain no credence because of our weakness and because they are obscured by the body. But in the intelligible world each and every thing is plain.

\section{THE INTELLECT}

Why ${ }^{15}$ now must we use the soul as a stepping-stone to something higher and not posit her as the first principle? In the first place because intellect is different from and better than soul, and what is better by nature comes first. Intellect is better, because soul does not as

1 Plotinus, Enneads, V. 9, \& 4, 557 E (C. p. 1030, 1. 16; V. II. 251, 1. 9) 
some think generate the intellect of her perfection. For how can the possible become actual, unless there be a cause which makes it actual? Were the process of actualization a matter of chance, perhaps the possible might not become actual. Hence we must regard our first principle as in actual existence, wanting nothing, and perfect. And the imperfect we must regard as coming later and as perfected by what has produced it, just as parents bring to maturity offspring which they generated in the beginning imperfect. Soul, moreover, is matter in comparison with her first cause, and then is formed and perfected by it. Again since soul is passible, there must be some impassible principle-or else all things in time would be destroyed-and something, too, prior to soul. Finally, since soul is in the world, there must be some principle outside the world, and this, too, must be prior to soul. For if what exists in the world exists in the corporeal and material, nothing there will preserve its identity. Hence the idea of man and all the forms will be neither eternal nor self-identical. From these considerations as well as from many others, it may be seen that intellect must exist prior to soul. ...

Although 16 then the soul is the kind of thing which our discussion has shown her to be, still she is merely a sort of image of the intellect. In fact, just as a thought expressed in words is an image of the thought in the soul, so she is both the thought of the intellect and the entirety of its activity and the life which it sends forth to constitute a new form of being. An illustration of I. 19).

10 Plotinus, Enneads, V. 1, § 3, 484 B (C. p. 900, 1. 4; V. II. 164, 
what I mean is fire which has both an inherent heat, and a heat which it radiates. . . .

It 17 is the intellect then which makes the soul ever more divine by its fatherhood and companionship. Nor does anything separate them save the fact that they are different, inasmuch as the soul is one lower in rank and is the receptive principle, whereas the intellect is, as it were, the form. Still even the matter of the intellect is beautiful since it is intelligible and simple. And the excellence of the intellect can be clearly estimated by this superiority to soul, which is such as we have described.

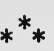

We ${ }^{18}$ should also see the excellence of the intellect, if first admiring the phenomenal universe with an eye to its grandeur and beauty, the orderliness of its eternal motion, its gods both visible and invisible, its spirits, and all its animals and plants, we should then rise to its far truer and more real archetype, and should see how all things there are intelligible and eternal of themselves and dwell in native reason and live with uncorrupted intellect at their head, and unspeakable wisdom and the true life of Chronos which is the offspring of God and the intellect. For the intellect comprehends everything that is immortal, every intellect, every god, every soul, in its eternal peace. Its peace, I say, for why should it in its felicity seek change? And into what could it change, seeing that it has all things of its own self. Nor will the intellect seek to develop itself, since it is absolutely perfect. Hence everything that shares its

${ }^{17}$ Plotinus, Enneads, V. 1, §3, 484 D (C. p. 901, l. 16; V. II. 165, 1. 3).

18 Ib., $\$ 4$. 
existence is perfect, to the end that it may be perfect in every respect, possessed of nothing imperfect and nothing which is not the object of its thought.

Its thought, however, is not a search but a possession. Its felicity, too, is not acquired from without. Rather is it eternally all things, and is the true eternity of which time encircling the soul is an image-time which leaves the old things behind and lays hold of new. For, to speak still of time, now one thing now another revolves about the soul, now Socrates, and now a horse, and always some single thing. The intellect, on the other hand, is all things. It contains all things in itself at rest within itself. Only the present exists for it, and is present eternally, and for it there is nothing future, since the future is already present to it, and nothing past. Nothing, I say, is past, but all realities have remained at rest there from eternity, as though content with themselves as they are. Each of them is intellect and real existence, and the sum of them is all intellect and all real existence.

The intellect in the act of thought produces existence, and existence by being thought gives thought and existence to the intellect. Of both existence and thought, however, there is yet another cause. For they exist simultaneously and never desert one another. But though two, they together constitute that unity which is at once intellect and existence, thinking and the object thought. Intellect this unity is qua thinking, existence qua the object thought, for thinking could not arise were there not identity and difference. The first principles then are intellect, existence, difference, identity. The categories of motion and rest, however, must also be included, motion if there is to be thinking, 
rest for the sake of identity. Difference must exist that there may be thinking and an object of thought. Take away the category of difference, and the unity which arises from thinking and the object of thought will be given its quietus. The ideas must also differ from one another, and yet be the same in that each is selfidentical and all have a common element. Their difference is otherness. These principles by virtue of their plurality generate number and quantity. Quality is generated by the fact that each one of these principles from which all else proceeds has its peculiar and proper character. ...

It 19 is necessary to understand then by intellect, if we are to attach any true significance to the name, not the potential intellect, or the intellectual knowledge developed out of ignorance. Did we, we should have to seek for yet another intellect prior to this. By intellect we are to understand that which is intellect in actu, and eternally. But if its thought be not imported from without, when it thinks anything it must itself be the occasion of its thought, and when it is possessed of any object be the occasion of that possession. But if it be the occasion and source of its thought, it will itself be the object of its thought. For were its essence one thing, and the object of its thought another, its essence would not be an intelligible object, and would exist potentially, not actually. The one then is not separable from the other, though it is our custom drawn from our own experience to think of them as separate.

10 Plotinus, Enneads, V. 9, §5, 558 C (C. p. 1031, 1. 14; V. II. 251, 1. 32). 


\section{SOURCE BOOK IN ANCIENT PHILOSOPHY}

What then is the object of the activity and thought of the intellect like, that we should regard the intellect as itself the object of its thought? Clearly the intellect, being real existence, must think and support the world of real existences (the ideas). It $i s$ then the real existences. It must think of these as existing either elsewhere than in itself, or in itself as its own nature. To think them as elsewhere than in itself is impossible. For where could they exist? It thinks them as constituting its own nature and existing in itself.

We come to this conclusion because the seat of the form is not the sensible object as some think. For in no case is the primary and fundamental the phenomenal. The form in sensible objects imposed upon matter is an image of real existence, and every form in objects comes from something without, refers thither, and is an image thereof.

Again, if there must needs be a maker of this universe, he will not think of what does not as yet exist, in order to create it. The forms of things then must exist prior to the world, not indeed as impressions struck from other things, but as archetypes and originals and the very essence of the intellect. If, however, some people talk of seminal reasons as sufficient, evidently they must be talking of the eternal reasons. But if the reasons are eternal and impassible, they must exist in an intellect, and in an intellect such that it is prior to conditioned existence, nature, and soul, seeing that these have a potential existence.

The intellect then is all real existences thought as not external to itself. They are neither prior nor subsequent to it, but it is, as it were, the primal lawgiver, or rather the law itself of existence. The saying then is correct 
that thinking and existing are one and the same thing, and that the knowledge of immaterial entities is the same as the things themselves-also the saying "I sought myself" [as] one of the real existences; and the doctrine of reminiscence is true too. For no real existence is outside the intellect, or in space. Rather do they exist eternally in themselves, subject neither to change nor destruction, and for this reason are real existences. On the other hand what is generated and destroyed enjoys existence as something superadded. Not they, then, but what is superadded, is real existence. Phenomena exist as definable objects through participation, in that their substratum gets its form from without. Thus bronze receives its form from the art of casting statues, and wood from that of carpentry, through the entrance into them of images of the arts in question. At the same time the arts themselves remain outside of matter in their self-identity, and contain the true statue and the true bed. This is also true of corporeal things. The difference between images and real existences is shown likewise by this universe which participates in images. For in the intelligible world real existences are immutable (whereas the things of this world are mutable), and being without extension reside in themselves without need of space, and have an intellectual and self-sufficient kind of existence. But the nature of corporeal things wants preservation by something outside itself, while the irtellect, which with its wonderful nature supports what naturally tends to fall, itself seeks no support.

\section{$*^{*} *$}

We ${ }^{20}$ grant then that the intellect is real existence and contains all the real existences in itself, not after a ${ }^{20}$ Plotinus, Enneads, V. 9, §6. 
spatial fashion, but as though they were its own self, and it were one with them. All things exist together there, and nevertheless are distinguished from one another. For the soul also is possessed of many notions at the same time, without confusing them. Each does its proper work at the proper time without involving the others. So, too, each thought has a pure activity drawn from the thoughts which lie within it. After this fashion, and to a far greater extent, the intelligible universe is all things together and yet not together inasmuch as each real existence is an individual and peculiar power. But the whole intellect includes them as a genus contains its species, or as a whole its parts. . . .

\section{$*^{*} *$}

Whatever ${ }^{21}$ appears in the phenomenal world as form is contained in the intelligible world, but what does not so appear has no place there. Hence there is nothing contrary to nature there, just as there is nothing contrary to art in the arts, nor for that matter lameness in the seed, seeing that lameness arises during growth from the failure of the seminal reason to overcome matter, and is a chance mutilation of form. In the intelligible world also are all harmonious qualities and quantities, numbers and magnitudes, conditions, actions and natural properties, motions and rests, both in whole and in part. In place of time there is eternity, and space there is represented by logical implication. . . . ${ }^{22}$ Are then only phenomena represented in the intelligible world, or are still more things? First we must inquire about artificial objects. . . .

${ }^{21}$ Plotinus, Enneads, V. 9, $\S 10,562$ (C. p. 1038, 1. 10 et V. II. $256,1.21$ ).

22 Ib., $562 \mathrm{E}$. 
As ${ }^{23}$ regards then art and artificial objects. Such arts as are imitative like painting and sculpture, dancing and gesticulation, which take their rise in the phenomenal world, and make use of a sensible model and imitate forms and motions, and repeat the symmetries which they behold, could not properly be referred to the intelligible world except as included in the idea of man. But if from the symmetry in animals we be led to reflect upon some condition of living beings in general, our reflection would be part of the power of considering the intelligible world, and beholding the symmetry of all things therein. Every sort of music, too, which is occupied with the concepts of harmony and rhythm, would be in the same class as an art occupied with intelligible rhythm. Also such arts as fashion sensible objects like architecture and carpentry get their principles and some of their skill from the intelligible world. But inasmuch as they have mixed their principles up with the phenomenal, they do not resicte wholly in the intelligible, but rather in man. Agriculture, however, which deals with sensible things like plants does not come from the intelligible, nor medicine which looks to earthly health, and busies itself with keeping people strong and in good condition. For in the intelligible world there is another kind of strength and health by virtue of which all living things are not subject to disturbance and are selfsufficient. Rhetoric and generalship, political economy and statesmanship, if they join beauty to their deeds and have the vision of it, get a portion of their wisdom from the wisdom on high. Geometry which deals with intelligible entities must be placed there, and also the highest wisdom which is occupied with real ${ }^{23}$ Plotinus, Enneads, V. 9, § 11, $563 \mathrm{~A}$. 
existence. So much must suffice for the arts and artificial objects.

Are ${ }^{24}$ there then also ideas of particular objects? Let us see. If I and every man can trace ourselves back to the intelligible world, then each man has his separate origin there. And if Socrates and the soul of Socrates are eternal, there will exist in the intelligible world a Socrates in himself as it is called, in so far as the souls of individuals are there. But if what was formerly Socrates becomes at another time another individual like Pythagoras or some one else, then the particular idea of Socrates no longer exists in the intelligible world. Still if the soul of the individual contain the seminal reasons of all those through whom it passes, all will be represented in the intelligible world. For we say also that each soul possesses all the seminal reasons that are in the world. If now the world contains the seminal reasons not only of man, but of particular animals, the soul will possess them too. There will then be an infinite number of seminal reasons, unless indeed they be periodically repeated in world-cycles, and in this way a limit set to their infinity, as often as they are reëxemplified.

However, if generally speaking there are more particulars produced than there are patterns, why need there be seminal reasons and patterns for everything produced within a single world-cycle? One archetypal man is enough for many men, just as a definite number of souls produce [in their reincarnations] an indefinite number of human beings. Still, different things have not the same seminal reason, nor is a single man sufficient as a pattern for men who differ from one another not only in point

${ }^{24}$ Plotinus, Enneads, V. 7, 1. 539 A (C. p. 995; V. II. 228). 
of matter, but in countless specific points. For such men are not related as the pictures of Socrates are related to the original, but their differences have to be regarded as due to different reasons or ideas. A worldcycle, however, in its entirety contains all the seminal reasons. And then [in the next world-cycle] the same world is repeated after the same ideas. Infinity in the intelligible world is not to be feared. For its infinity is all contained in the indivisible, and proceeds from it, as it were, when the intelligible world exercises its proper activity....

\section{THE ONE}

Everything ${ }^{25}$ which exists, both primary existences and whatsoever is in any way spoken of as being, exists by virtue of its unity. For what would a thing be were it not one thing? Take away its unity and it is no longer what we define it to be. There is for instance no army except it be a unity, and no chorus or flock which is not one. Nor is there any house or ship which has not unity, since the house is a single thing, and likewise the ship. If this unity be lost, the house is no longer a house nor the ship a ship. Compound and extended bodies then could not exist, unless unity were present in them. And if cut up, so far as they lose their unity they change their existence. So too, the bodies of plants and animals which are each a unit, if in being broken up they escape from unity into plurality, destroy the essence which they had and are no longer what they were, but become something else, and this indeed only in so far as they are still units. Health also exists when the body is organized as a unit, and beauty when the nature of the one holds the parts together, and virtue in the

${ }^{25}$ Plotinus, Enneads, VI. 9, § 1, 757 A (C. p. 1385; V. II. 518). 
soul when she is made a unit and unified in a single harmony. ...

We must now see whether the unity and the being of the individual be the same, and existence in general identical with the One. But if the being of each individual is a plurality, and the one cannot be many, then they must be different. Now man is both an animal and a rational being, and has many parts which in their multiplicity are bound together in unity. Man then is one thing, unity another. Man is divisible, unity indivisible. Also existence in general, since it comprises within itself all the real existences, is multiple in nature, and different from unity, and by participation possesses and shares in unity. Real existence has both life and intellect-since it is no lifeless corpse. Hence it is multiple. And if the intellect be real existence, it must be multiple, and still more so, if it comprise the ideas. For the idea is not one but is rather a number of thingseach individual idea as well as their sum total. They are one in the same sense as the universe is one. Generally speaking, too, unity is fundamental and primal, but the intellect, and the ideas, and real existence are not primal. Each idea is made up of many parts, is composite, and a consequent, inasmuch as what a thing is composed of is prior to it.

That intellect cannot be primal is also plain from the following considerations: The intellect necessarily is in thought, and since it regards what is both supremely good and at the same time not external to itself, the object of its thought is prior to itself. For in reverting to itself it reverts to its origin. Moreover, if it be both the thinking and the object of thought, it is dual, not simple, and is not the One. But if it regard another than itself, 
it will regard what is in every respect better than and prior to itself. If, however, it regard itself, it regards [qua thinking] what is better [qua object of its thought] than itself, and so is a secondary entity.

Now we must consider the intellect such that it communes with the good and the first of all things, and regards it, and also communes with itself and thinks itself, and thinks itself as the whole world of real existences. Its variety then falls far short of being unity. The One cannot be all things, since in that case it would be no longer One, nor can it be intellect since it would then be all things because the intellect is all things. Nor can it be existence, for existence is all things.

What now is the One? What is its nature? It is no wonder that we cannot easily say, in view of the fact that neither existence nor form is easily described. Yet our knowledge is based upon forms and concepts. But the more the soul proceeds into the formless, the more she becomes unable to comprehend it, because it is indefinable and lacks the impress of variety. Hence she wavers and begins to fear that she has laid hold of blank nothing, and tires at such a height and is glad to descend frequently and to fall back from everything till she has reached the phenomenal world. There she rests from her labors as if on firm ground once more. In the same way our sight when wearied with tiny things gladly falls upon large objects. On the other hand when the soul desires vision absolutely of and by itself, in this vision which comes through communion and union she does not believe that she has attained the object of her search through union with it, just because the object of her thought is not a different thing from herself.

We, however, who are going to make the One the 
object of our philosophic meditation must needs do as follows. Since it is the One which we are searching for, and the source of all things, the good and the primal, which we are beholding, we must not depart from the neighborhood of things primal, nor sink to those which come last, but must strive rather to betake ourselves from them and their show of sense to the primal things. We must free ourselves from all vice, too, if we be eager for the good, and must rise to the principle hidden within ourselves, and throwing off our multiplicity become one, and be made that principle and a beholder of the One. We must become then intellect, and intrust our souls to our intellect, and establish them there, so that we may be conscious of what the intellect beholds, and through it enjoy the vision of the One. We must not add thereto any sense-experience, nor receive into our thought anything that comes from sense, but with the pure intellect, and the primal part of the intellect behold the Most Pure.

If now, when so prepared, we attribute in our imagination either extension or form or mass to this nature, it will not be intellect which guides our vision, because these properties are not naturally objects of intellectual vision, but rather of the activity of sense, and opinion which follows sense. We must rather get from the intellect views of what lies within its power. Now the intellect can behold either what is prior to itself, or its own nature, or what comes after it. Pure is its own nature, but still purer and simpler what are or rather is prior to it. This is not intellect but prior to intellect. For intellect is something which exists. But this other nature is not something, but is prior to everything. It is not an existence, for what exists has the form of ex- 
istence, and it is formless, even without intelligible form. I say this, because the nature of the One being the creator of all things is itself no one of them. So it is not a thing, nor quality, nor quantity, nor intellect, nor soul, nor in motion, nor at rest, nor in space, nor in time, but is the absolutely "monoform," or rather formless, prior to all form, prior to motion, prior to rest. For these things pertain to existence, and it creates them in their multiplicity.

Why now, if it be not in motion is it not at rest? Because either or both of these properties pertain to being, and what is at rest is so by virtue of stability, and is not the same as stability. Hence stability is an attribute of it, and it is no longer simple. Also if we call the One a cause, we are not predicating something of it, but rather something of ourselves, inasmuch as we are receiving something from it while it exists in itself. Again, strictly speaking we cannot talk of the One as a "this," or a "that," but looking at it from without, may only wish to interpret the ways in which it affects us. Now we get nearer to it, now we fall farther short of it, because of the difficulties that hedge it about.

The greatest of these difficulties is that our apprehension of the One does not partake of the nature of either understanding or abstract thought as does our knowledge of other intelligible objects, but has the character of presentation higher than understanding. For understanding proceeds by concepts, and the concept is a multiple affair, and the soul misses the One when she falls into number and plurality. She must then pass beyond understanding, and nowhere emerge from her unity. She must, I say, withdraw from understanding and its objects and from every other thing, even the 
vision of beauty. For everything beautiful comes after it and is derived from it, as all daylight from the sun. It is for this reason that Plato says that the One is ineffable in spoken or written word. We speak and write of it, however, that we may despatch our spirits toward it, and rouse them from the contemplation of mere concepts to the vision of it, pointing out the way, as it were, to one eager for some sight. Instruction goes as far as showing the road and the way. But the vision is the work of him who has already willed to behold it. . . .

In ${ }^{26}$ what sense now is the One one? And how is it to be grasped by our thought? I reply, it must be regarded as more one than monad or point. For with these latter entities the soul subtracts magnitude and numerical quantity and stops and rests at the smallest possible remainder-which is indivisible in truth, yet was contained in the divisible and is found in other things. The One, however, is found neither in other things, nor in the divisible, nor is it indivisible in the sense in which the smallest possible remainder is indivisible. It is the greatest of all things not in extension, but in power, and hence space and extension have nothing to do with its power. The real existences which come next to it in rank, are also indivisible and undivided in a dynamic not a spatial sense. We are to understand, too, that it is infinite not by virtue of being immeasurable in extension or number, but because its power cannot be comprehended or circumscribed. When you think of it as intellect or God, it is more. And when you unify

20 Plotinus, Enneads, VI. 9, \&6, 763 E (C. p. 1397, 1. 17; V. II. 515, 1. 20). 
it in your thought it is more-more even than you could imagine God himself to be, if you imagined him to be more one than your thought. For it exists in itself and has no attributes.

One would not be wrong perhaps in representing God's unity through the concept of self-sufficiency. For he must be the sufficient and self-sufficing, and free from wants of all things, whereas everything which is multiple and not one wants, since it has been made of many things, and its essence stands in need of unity. But the One does not stand in need of itself, since it is itself. Moreover, a thing which is multiple needs as many things as it is composed of. And all such things are subsequent to their components, and not selfexistent, but need other things, and display this need both in their parts and as wholes.

If then there must be something which is absolutely self-sufficient, this must be the One, and must be so in this respect alone, namely, that it wants nothing in relation either to itself or to other things. The One seeks nothing in order that it may exist or be happy, nor yet anything to support it. Since it is the cause of all else, it owes its own existence to nothing else. For the same reason why should its happiness be an object external to itself? It follows that happiness is not an attribute of the One. The One is happiness. Furthermore, it is not to be found in space, secing that it needs no space as if it were not able to support itself. What has spatial position is inanimate and is a falling mass if it be not placed in position. Things have position for the same reasons that they coexist, and each has the place to which it has been assigned. What needs, however, a place in space wants something. 
Then too the source does not need the things which follow after it, and the source of all things has no need of any. For what wants, wants in the sense that it strives after its source. Again if the One needs anything, it is clearly seeking not to be One, and hence needs its own destruction qua One. Everything which wants, however, stands in need of well-being and preservation. It follows that for the One, nothing can be good, nor can it wish anything. It is rather super-good, a good not for itself but for other things, if any of them be able to attain it. Nor can the One be thinking, lest there be difference and motion in it. It is prior to motion and to thinking. For what shall it think? Itself? In that case before it thinks it will be ignorant, and what is selfsufficient will need thought in order to know itself. But it does not follow that because it does not know or think itself, it will be ignorant of itself. For ignorance has to do with an external object, as when one thing is ignorant of another. But the Only One will neither know anything, nor have anything to be ignorant of. Being One and united with itself it does not need to think of itself. You camnot even catch a glimpse of it by ascribing to it union with itself. Rather must you take away thinking and the act of being united, and thought of itself and of anything else. It must not be conceived as the thinker, but more after the fashion of mere thought, which does not think but is the cause of thinking in something else. The cause, however, is not the same as the caused, and the cause of all things is no one of them. It must not then be called the good which it gives to other things, but in some other sense the good above all other goods. 
The ${ }^{27}$ One is all things and yet no one of them. For the origin of all things is itself, not they, yet all things are in their origin inasmuch as they may all be traced back to their source. It is better, perhaps, to say that in their origin they exist not as present but as future things. How then can they proceed from the One in its simplicity, in whose self-identity there is no appearance of variety or duality whatsoever? I reply, for the very reason that none of them was in the One, are all of then derived from it. Furthermore, in order that they may be real existences, the One is not an existence, but the father of existences. And the generation of existence is as it were the first act of generation. Being perfect by reason of neither seeking nor possessing nor needing anything, the One overflows as it were, and what overflows forms another hypostasis. . . For ${ }^{28}$ whenever anything else comes to perfection we see that it procreates and, unwilling to remain in itself, creates another being. This is true not only of beings which possess conscious purpose, but also of things which develop without conscious purpose. Indeed, even inanimate objects share themselves as far as may be. Thus fire heats and cold chills and drugs have their appropriate effects upon other things, and all things imitate their origins as they are able with a view to their everlasting self-perpetuation and goodness. How then should the most perfect and primal good stay shut up in itself as if it were envious or impotent? And it the power of all things! How could it be the origin of anything? Something then must be begotten of it, if any of the other hypostases which are

${ }_{27}$ Plotinus, Enneads, V. $\$ 2,493$ (C. p. 918 ; V. II. 176).

${ }^{28}$ Ib., V. $\$ 4,517$ (C. p, 9.58, 1. 17 ; V. II. 203, 19). 
derived from it are to exist. Necessarily, then, something comes from it. Also what begets all that comes after it must be most worthy of worship, and the hypostasis second to it better than any other created thing. . . .

\section{$*^{*} *$}

If ${ }^{29}$ now there be an hypostasis second to it, and it be unmoved itself, the second hypostasis must come into being without any inclination or will or motion of any sort on the part of the One. How is this accomplished and how are we to think of this second hypostasis that surrounds the abiding and changeless essence of the One? We are to think of it as a radiance proceeding from the One, and from the One abiding in its changelessness, just as the light about and surrounding the sun is eternally generated from it, without any change or motion in the solar substance. Indeed all things while they last necessarily give of their own power an hypostasis proceeding from their own essence, outside of and surrounding them, and attached to them-an image as it were of the archetypes which have brought it forth. Fire dispenses heat from itself, and snow does not keep its cold only within itself. But the best witnesses of this fact are sweet-smelling substances. For as long as they exist there goes forth something from them which surrounds them and is enjoyed by any one who happens to stand near. And everything on attaining perfection generates, and what is eternally perfect eternally generates the eternal; but what is generated is less than the generator. What now are we to say of the most perfect? Nothing comes from it but what is greatest after it. And the greatest after it and second in rank is the intellect. . . . 1. 15).

20 Plotinus, Enneads, V. $\$ 1,487$ (C. p. 906, 1. 16; V. II. 168, 
We ${ }^{30}$ say that the intellect is an image of the One. But we must speak with more precision. In the first place we call it an image because it is begotten of the One, and preserves much of the nature of the One, and is very like the One, as light is like the sun. But it is not the One. How then does the One generate the intellect? In this wise-through what is generated by it turning back to behold it. This vision is the intellect. . . . That ${ }^{31}$ world of which the One is the possibility, the intellect perceives, separating it as it were from its possibility. Else it would not be intellect, since the essence of intellect consists in a kind of awareness of its possibilities and powers. It defines then through itself its own being by virtue of the possibilities got from the One. It is as it were a part of what comes from the One, and gets its essence thence and is established by the One, and perfected in essence from and of it. It sees that to itself as to the divisible from the indivisible have come life and thought and all things, and that the One is none of them. ... This ${ }^{32}$ intellect so begotten is worthy of being the purest intellect, and has no other source than the first principle [the One]. In being begotten, it generates everything else with it, all the beauty of the ideas, all the intelligible goods. And it is filled with everything it generates, and swallows them again, so to speak, and contains them within itself lest they fall into matter. . . .

Now ${ }^{33}$ the intellect being like the One follows the example of the One and pours forth a mighty power. This power is a particular form of itself, as was the case

${ }^{30}$ Plotinus, Enneads, V. $\$ 1488$ A. $\quad{ }^{31}$ Ib., 488 B. $\quad{ }^{32}$ Ib., 489 A. s3 Ib., V. $\S 2,494$ (C. p. $919,1.9$; V. II. 176, l. 18). 
with that which the principle prior to intellect poured forth. And this activity proceeding from essence is soul, begotten without change or motion in the intellect-for intellect was begotten without change or motion in the principle prior to it. But the soul does not create, abiding in her changelessness, but in change and motion she generates an image. Looking to the source of her existence, she is filled with intellect, but when she proceeds to other and opposite motions then she generates an image of herself, sensation and the nature in plants. But none of these things is removed or cut off from what is prior to it. ... $*^{*} *$

There ${ }^{34}$ is then a procession from the origin of all things to the last and least of them, and each is left in its appropriate position. What is begotten holds another and lower place than what begets, yet each thing remains identified with that which it follows, as long as it seeks after it.

3s Plotinus, Enneads, V. § 2, $494 \mathrm{~A}$. 


\section{XXIII}

\section{PLOTINUS-Continued}

\section{MATTER}

$\mathrm{IF}^{1}$ now the world of real existences and what transcends real existence is such as we have described, no evil can inhere either in real existence or in the transcendent One. For they are good. If then evil exist, there remains for it the sphere of not-being, and it is as it were a certain form of not-being, and is concerned with things mixed with not-being or having some commerce with it. By not-being I do not mean absolute nonexistence, but only what is different from real existence. Nor do I mean not-being in the sense that motion and rest which are attributes of being are not being, but rather in the sense of an image of real existence, or of something which has even less existence than an image.

What I am alluding to is the phenomenal universe and all the affections of the sensible world. Or it may be it is either something which follows upon the phenomenal, and is as it were a property thereof, or else is its origin or some one of the things which go to make up the sensible world, such as it is. And one might come to think of it as lack of measure with respect to measure, and as infinity with respect to finitude, and formless with respect to the formative, and eternally wanting with respect to the self-sufficient, as indeterminate, never

${ }^{2} \mathrm{P}^{\prime}$ otinus, E'nneads, I. 8, § 3, 73 D (C. p. 139; V. I 101). 375 
at rest, subject to every affection, insatiate, poverty absolute. These characteristics are not properties of it but its essence, and whatever part of evil you may see you will find has them all.

Now whatever else participates in it and is assimilated to it becomes bad, yet is not the principle of evil. What then is the hypostasis in which evil is present not as something extraneous but as the hypostasis itself? For were evil an attribute of something else, there must needs be something prior to it, even if it be not an essence of some sort. Just as there is good the principle, and good the predicate, so there is also evil which exists as a principle, and evil predicated according to this principle of some other subject. But, do you say, what is measuredness if it does not consist in being measured, what measure if it does not lie in the measured? I reply that just as there is measure beside what is measured, so there is unmeasuredness which is not merely in the thing unmeasured. For did it exist in some other subject, it must exist either in the unmeasured-which is impossible since it has no need of unmeasuredness, being itself unmeasured-or in the measured, which is impossible since the measured cannot possess unmeasuredness in so far as it is measured. Hence there must be something infinite in itself, and formless in itself and everything else aforesail which characterized the nature of evil. And if anything else be evil, it either has evil by admixture, or by regarding it, or by performing it. That, then, which underlies figures and forms and structures and measures and bounds, and is adorned with an orderliness foreign to it, having nothing good of itself, and being a mere phantom as compared with the soul, the very essence of evil, if evil can have an essence-that, I 
say, is discovered by our discourse to be the primal and the absolute evil. . . .

$\mathrm{We}^{2}$ must now consider the meaning of the saying that evil cannot be destroyed but exists of necessity, and that it does not exist among the gods, but ever hovers about this mortal nature of "this place." The meaning is that the heaven is pure of evil, and goes with a regular and orderly motion, and that there is no unrighteousness there, nor other vice, nor injury of one part by another in their appointed courses; whereas on earth there is unrighteousness and disorder. This is what Plato means by mortal nature, and the phrase "this place." And the duty of fleeing hence is not to be taken locally as referring to earthly places. Our flight, he says, does not lie in going away from the earth, but in living on earth in righteousness and holiness and sweet reasonableness, which is as much as to say that we must flee from vice. It is vice then and its consequences that he means by evil.

But when Theodorus in the dialogue answers that evil could be removed if only men could be persuaded of the truth of this opinion, Socrates answers that this could not possibly happen, since evil exists of necessity, seeing that there must be some opposite to the good. . . . But ${ }^{3}$ in what sense does it follow that if good exists evil also will exist? In this, I say, that there has to be matter in the universe. For this universe is necessarily composed of opposites, and could not exist were there no matter. The nature of the universe is mixed, as Plato says, of reason and necessity. And whatever comes to it from

2 Plotinus, Enneads, I. 8, 75 G (C. p. 144, 1. 6; V. I. 104, 1. 29)

- Ib., $\$ 7,77$ B (C. p. 147, 1. 6; V. I. 106, 1. 31). 
God is good, but the evil comes from the primeval nature, by which he means the underlying matter as yet unbeautified by form. . . . From ${ }^{4}$ what has been said then we can now understand the necessity of evil. Since the good is not solitary, there must necessarily result from the emanation or, if one prefer, from the degeneration and departure from the good, something ultimate and last, beyond and after which nothing more can be generated. This ultimate and last thing is evil. That something should follow from the first principle is necessary, hence this last thing is necessary. And this is matter which has no remainder of the good and the first in it. Hence the necessity of evil.

That ${ }^{5}$ there must be some substratum in bodies different from the bodies themselves is evidenced by the conversion of the elements into one another. For the destruction of what is converted is not complete since, if it were, a substance would be put out of existence. Nor does what is generated come into being from absolute not-being. There is rather a change of form from one form to another. In change that remains changeless which receives the form of what it becomes, and puts off the form of what it previously was. Destruction shows this plainly, for it pertains to compound objects. If this be true, everything is composed of matter and form. Induction bears witness also, in showing that what is destroyed is compound, also analysis. For example if a cup can be dissolved into gold, and gold into water, analogy demands also that the water be dissoluble. The elements then must be either form or primitive mat-

- Plotinus, Enneads, I. § 7, $77 \mathrm{E}$.

- Ib., II. 4, §6, 162 C (C. 288,1 , 3; V. I. 154, 1. 30). 
ter or a composite of matter and form. It is impossible, however, that they should be form, for how could they have magnitude and extension without having matter? But they cannot be primitive matter, seeing that they are destroyed. They are then a composite of matter and form, form in respect to quality and structure, matter in respect to a substratum which is indeterminate because it has no form.

What then is this substratum which we say is one and continuous and without quality like? That it cannot be corporeal if it is without quality is plain enough. If we say that it is the matter of all sensible objects-I don't mean the matter of some, and form in relation to others as clay is matter for the potter yet absolutely speaking not matter, but I do mean matter in relation to everything-we ought not to attach to its nature any property perceived in sensible objects. In that case, in addition to qualities like colors and heat and cold, we ought not to attribute to it lightness or heaviness or density or rarity or structure and hence not even extension. For extension is one thing, that which is given extension another, structure one thing, that which is given structure another. It must also not be compound but simple and one in nature. For in this wise is it empty of all attributes.

And what gives it form will give it a form which is different from and independent of matter, bringing extension and everything else to it from the realm of real existences. Otherwise the formative principle would be conditioned by the extent of matter on hand, and would do not as it wishes but as matter wishes. That its will should coincide with the extent of matter is an absurd supposition. But if the formative principle be prior to 
matter then matter will be entirely such as the principle wishes and will be easily cast into all sorts of forms, and hence into extension. But if it had extension it would also possess a structure, and hence would be more intractable. Form then enters into it and brings everything to it. The form possesses everything, even extension and everything else which is contained in the seminal reason and exists through its agency. It follows from this that in the case of particular kinds of things their quantity is determined along with their form. For the quantity of a man is different from that of birds, and of this or that bird. It is no more remarkable that quantity should bring a new property to matter than that quality should. Nor could quality be a seminal reason, and quantity, which is measure and number, not a form. ...

If ${ }^{6}$ however, the substratum were some quality which all the elements had in common, we should have in the first place to say what that quality was, and then to show how a quality could be a substratum, and how quality could be seen in the unextended with neither matter nor extension to it; and yet again, how if quality be determinate it can be matter. On the other hand were it something indeterminate it would not be quality but substratum and the matter which we are looking for. But one may object at this point-granted that matter has no qualities in that its nature is to partake of none, what is still to prevent its being qualified by just this fact, that it partakes of none, and to hinder it from possessing a property in all respects peculiar to itself, and

- Plotinus, Enneads, II. 4, §13, 167 B (C. p. 298, 1. 14; V. I. $162,1.8)$. 
from differing from all other qualities in this very point of being an absence or privation of every quality? One who has been deprived of any quality is qualified by his privation, as for example a blind man. If then an absence or privation of qualities be attributed to matter why is it not qualified thereby? And if absolute privation be ascribed to it why is it not even more qualified? That is, of course, if privation be a kind of quality.

If, however, a man argue thus, what is he doing but turning everything into qualifications and qualities? Quantity then would be a quality, and essence. But if a thing be qualified, quality is added to it. It is, however, absurd to make a qualified thing of what is different from the qualified and is not qualified. Or do you say that it is qualified by the fact of this difference? But if you mean that matter is sheer absolute difference then it cannot be qualified, since simple quality is not itself a qualified thing. If you mean, on the contrary, that matter is merely different from other things, then it is merely different, not of its own nature but by virtue of difference, and the same by virtue of sameness. Privation then is not quality or a qualified thing, but is a want of quality or of anything else, just as silence is a want of sound or of anything else you please. For privation is negation, and the qualified is found in the sphere of the positive. The peculiar property of matter is not form, but rather not being qualified and not having any form. It is absurd to say that what is not qualified is qualified. That is like saying that a thing has not extension for the very reason that it has.

Moreover this peculiar property of matter is not something different from the essence of matter and is not 
added to it, but lies rather in the relation matter bears to other things, to wit, that it is something different from them. Other things, however, are not merely "other," but each has an individual form. Matter, on the contrary, ought properly to be called merely "an other," or perhaps "other" in the plural, so that you may not determine it by using the singular, but by the use of the plural indicate its indeterminate character. . . .

\section{$*^{*} *$}

But ${ }^{7}$ if matter be without quality how can it be evil? I reply that it is defined as without quality in the sense that it possesses itself none of those qualities of which it is receptive and which inhere in it as a substratum, but not in the sense that it has no nature. If, however, it have a certain nature, what prevents this nature's being evil? I do not mean evil, as qualified thereby. For quality is that by predication of which something else is qualified. It is then an attribute and is located in a subject other than itself. But matter is not located in a subject different from itself, but is the substratum of which all attributes are predicated. Since then every quality is by nature a predicate, and matter happens to have no predicates, matter is said to be without quality. Again if quality is itself unqualified, how could matter which has received no qualities be called qualified?

It is correct then to speak of matter both as having no qualities, and as being evil. For it is not called evil because it has qualities but rather because it has not, lest otherwise it were evil from being form, and not from being the nature opposite to form.

'Plotinus, Enneads, I. 8, §10, 79 C (C. p. 152; V. I. 110, 1. 8). 
Finally 8 how are we to have knowledge of the unextended in matter? And how are we to know anything that has no qualities? And what must be the concept thereof, and the starting-point for our reflection? I say, indeterminateness. For if like is known by like, then the indeterminate is known by the indeterminate. There might indeed be a definite concept of the indeterminate, but the point from which we must start toward it is indeterminate. And if each thing be known by means of conception and thought, and here the concept tells what it ought to tell about matter, and still the thought which we desire is not a thought but rather the absence thereof, then our representation of matter would be rather a bastard and illegitimate concept, born of the untrue principle of the Other, and mixed with it. Perhaps it is with this in his mind's eye that Plato talks of matter as apprehended by a bastard concept.

What, however, is the indeterminateness of the soul? Is it a complete ignorance like an absence of all knowledge? No, the indeterminate has a kind of positiveness, and just as for the eye darkness is the matter of all invisible colors, so the soul when she takes away everything from sensible objects as one might take away light, and is left with something which it is no longer possible to define, becomes like the eye in the dark, and finally is in a sense identified with what she sees. What then does she see? Something like formlessness and want of color and absence of light, and also lack of extension. Otherwise this something will present itself in some form or other. But when she sees nothing is she not affected in

- Plotinus, Enneads, II. 4, \& 10, 164 D (C. p. 292, 1. 14; V. I. 158, l. 4). 


\section{SOURCE BOOK IN ANCIENT PHILOSOPHY}

the same way? Not at all. For when she sees nothing, she reports nothing, or rather she is not affected at all. But when she sees matter she is affected as it were by an impression of the formless. And when she thinks of what has form and extension, she thinks of something compound, as colored and as concretely determined. She thinks of the whole, and thinks of it as all belonging together, and her thought or perception of its properties is clear. But her thought of the formless substratum underlying them is obscure, and obscure is the nature of the formless substratum underlying them, for it is without form. There is then a residuum in the whole and compound object which is comprehended along with the properties, and is left by reason in its analysis and abstraction of the properties. And this the soul thinks obscurely as an obscure thing, and darkly as a dark thing, and thinks it by not thinking. But since matter itself does not remain formless but has been given form in concrete things, the soul also immediately adds the form of concrete things to it, being pained by the indeterminate as if afraid of being beyond the pale of real existence, and not suffering herself to stop long in the realm of not-being.

\section{SIN AND SALVATION}

The ${ }^{9}$ soul is not essentially vicious, and again every soul is not vicious. What then is a vicious soul? She, says Plato, who has become the slave of a man whose nature engenders evil in her through the reception of evil and lack of measure and superfluity and deficiency on the part of her irrational form. From these characteristics wantonness and cowardice and the rest of the soul's

- Plotinus, Enneads, I. 8, § 4, 740 (C. p. 141, 1. 3; V. I. 102, l. 22). 
vices arise, as involuntary affections provocative of false opinions and estimations of the good and evil which she shuns and pursues. What, however, is it that is responsible for this viciousness, and after what fashion are we to refer vice to an origin and cause?

I reply that in the first place the vicious soul is not outside of matter and is not wholly herself. She is mixed with disproportion, and is without part in the form which brings order and induces proportion. For she is mingled with the borly which is material. In the second place, if her reasoning faculty be damaged, her vision is hindered both by her affections, and by being darkened by matter and inclined toward matter, and in general by her looking not toward existence but toward generation. And of transition and generation the nature of matter is the source, a nature so evil that the soul which even looks toward it, though it be not yet in it, is filled with evil. For since matter is wholly without part in the good and is the privation thereof, and pure lack, it makes like to itself everything whatsoever which touches it.

The soul, however, which is perfect and ever inclined to the intellect is ever pure and turned from matter, and neither sees nor approaches anything which is indeterminate, or without measure, or evil. She remains then pure, absolutely determined as she is by the intellect. But if she does not remain so, but goes forth from herself, then she is on an imperfect and secondary plane of existence, and is a mere shadow of her former self because of her failure in so far as she has failed, and is filled with disproportionateness and sees darkness. At this point she already has hold of matter, seeing what she does not see, just as we talk about "seeing the dark." 
Now 10 often I am roused from the body to my true self, and emerge from all else and enter myself, and behold a marvellous beauty, and am particularly persuaded at the time that I belong to a better sphere, and live a supremely good life, and become identical with the godhead, and fast fixed therein attain its divine activity, having reached a plane above the whole intelligible realm; and then after this sojourn in the godhead I descend from the intelligible world to the plane of discursive thought. And after I have descended I am at a loss to know how it is that I have done so, and how my soul has entered into my body, in view of the fact that she really is as her inmost nature was revealed, and yet is in the body. . . .

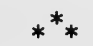

In ${ }^{11}$ seeking to learn Plato's teaching concerning our souls, we are forced to inquire in addition into the question of soul in general, and ask how it comes in the nature of things to have commerce with the body. Also we ought to consider the nature of the universe in which the soul lives. . . . The ${ }^{12}$ body of the world, we find, is complete and sufficient and self-sufficing, and has nothing in it contrary to nature. Hence it needs but slight ordering, and its soul is eternally as she wishes herself to be, and is without desires or affections. Nothing is absent from her, and nothing is added to her. So it is that Plato says that our soul when in the companionship of that perfect world-soul becomes perfect herself, lives on high and directs the whole universe. Did she not separate herself therefrom and enter into bodies and become the

10 Plotinus, Enneads, IV. 8, $\$ 1,468$ (C. p. 872; V. II. 1. 142).

"Ib., § 2, 470.

12 Ib., $470 \mathrm{C}$. 
soul of some particular body, she herself like and with the world-soul would easily govern the universe. It is not then under all circumstances an evil thing for the soul to provide the possibility of existence and wellbeing to a body. For not all providential care of things inferior deprives him who exercises it of living on the best and highest level. . . .

\section{$*^{*} *$}

There ${ }^{13}$ are two ways in which the commerce of the soul with bodies may cause trouble. In the first place it may be a hindrance to thought, and secondly it may fill the soul full of pleasures and desires and griefs. Still neither of these contingencies should occur in the case of a soul that has not sunk into the interior of the body, nor is the soul of a particular body nor has come to belong to one-a case where rather the body belongs to the soul, and is such as to have no want or deficiency, and hence as not to fill the soul with desires or fears. For nothing to fear occurs to her in connection with such a body, nor does any want of leisure make her incline downward and lead her away from the better and beatific vision. On the contrary the soul of such a body is ever in the higher regions ordering the world with a power free from all care.

Now, ${ }^{14}$ individual souls which are endowed on the one hand with inclination toward the intellect, turning as they do to that which generates them, and on the other possess a power which reaches even to this terrestrial sphere, just as light both depends on the sun above and yet does not grudge giving itself to the world

13 Plotinus, Enneads, IV. 8, § 2, 471 A.

14 Ib., 472 A, §4. 


\section{SOURCE BOOK IN ANCIENT PHILOSOPHY}

below; individual souls, I say, are without sin so long as they remain with the world-soul in the intelligible world, and in heaven rule things in her company. Like kings associated with the ruler of all things they reign jointly with her without descending from their royal thrones. And they are co-regents with her because they are conjoined with her in the same royal state. But if they alter their mode of existence and change from the whole to the part, and take to existing independently and of themselves, and find, so to speak, their association with the world-soul irksome, they revert each to an independent existence. When they have done this for some time, and have deserted the world-soul and estranged themselves from her through their separation, and no longer regard the intelligible universe, then each becomes a part and is isolated and weakened and busied with many things, and regards the part instead of the whole. And then when each through her separation from the whole has lighted upon some one particular part, and has deserted everything else, and turned to and entered into that one part which is subject to the impact and influence of other things, her apostasy from the whole is accomplished, and she directs the individual surrounded as he is by an environment, and is already in contact and concerned with external things, and lives in their presence and has sunk deep into them. Then it is that she is aptly said to have lost her wings and to lie in the bonds of the body-erring as she is from her life of innocenee passed in governing the higher world at the side of the world-soul. This prior state is altogether better if she will but return thither, but as it is, she is fallen and fettered, and inasmuch as she exercises her activities through the medium of sense, because pre- 
vented in the beginning from exercising them through the intellect, Plato talks of her as buried and in a dark cave.

But her return to pure thought when through her recollection of her former state she gets a point of departure toward the vision of real existence is called a loosening of her bonds and an ascent to the upper world. For despite her fall the soul has always a higher part.

\section{$*^{*} *$}

The ${ }^{15}$ soul then has naturally a love of God and desires to be united with him with the love which a virgin bears to a noble father. But when she has betaken herself to creation, deceived as it were in her nuptials, she exchanges her former love for mortal love, and is bereft of her father and becomes wanton. Still if she begin again to hate the wantonness of earth, she is purified and turns once more to her father and all is well with her. Those to whom this heavenly love is unknown may get some conception of it from earthly love, and what joy it is to obtain possession of what one loves most. Let him then reflect that these objects of his love are mortal and perishable, mere shadows for his love to feed upon, and soon turned to loathly things, because they are not the true beloved, nor our good, nor what we seek; whereas in the higher world we find the true beloved with whom it is possible for us to unite ourselves when we have seized and held it, because it is not clothed with flesh and blood.

He who has beheld this beloved knows the truth of what I say, how the soul then receives a new life when she has gone forth to it, and come to it and participated in it, so that in her new condition she knows that the

${ }_{1 s}$ Plotinus, Enneads, VI. 9, 768 C (C. p. 1406, 1. 10: V. II. 521, 1. 20). 
giver of true life is beside her, and that she needs nothing else. Such an one knows also, however, that we must put all else away, and abide in the beloved alone, and become only it, stripping off all else that wraps us about; and hence that we must hasten to come forth from the things of this world, and be wroth at the bonds which bind us to them, to the end that we may embrace the beloved with all our soul, and have no part of us left with which we do not touch God. It is possible for us even while here in the body to behold both him and ourselves in such wise as it is lawful for us to see. Ourselves we see illumined, full of the light of the intelligible, or rather as that very light itself, pure, without heaviness, upward rising. Verily we see ourselves as made, nay, as being God himself. Then it is that we are kindled. But when we again sink to earth, we are, as it were, put out.

But ${ }^{16}$ why then do we not remain in the vision? I reply, because we have never wholly come forth from our earthly selves. But there shall come a time for us when the vision will be unbroken, and we are no longer disturbed by any unrest of the body. It is not the faculty of vision which is disturbed but some other, when the seer leaves the vision unaccomplished, but deserts not the knowledge which lies in demonstration and belief and the dialectical operation of the soul. The seer and his seeing, however, are no longer reason and reasoning, but superior to reason and prior to reason and extraneous to reason, even as is the object of the vision.

Now whosoever beholds himself, when he beholds his real self will see it as such a being, or rather he will be

16 Plotinus, Enneads, VI. 9, $\delta 10$. 
united with such a being, and feel himself to have become such as is wholly simple. Indeed we ought perhaps hardly to say "he will see himself." Nor should we speak of an object of his vision, if we have to mean thereby a duality of the seer and the seen and do not identify the two as one. It is a bold thing to say, but in the vision a man neither sees, nor if he sees, distinguishes what he sees from himself nor fancies that there are two-the seer and the seen. On the contrary it is by becoming as it were another than himself, and by neither being himself nor belonging to himself that he attains the vision. And having surrendered himself to it he is one with it, as the centre of two circles might coincide. For these centres when they coincide become one, and when the circles are separated there are two centres again. And it is in this sense that we too speak of a difference. It follows that the vision is hard to describe. For how could a man report as something different from himself, what at the time of his vision he did not see as different but as one with himself?

This is clearly the intent of that injunction of the mysteries which forbids communication of their secret to the uninitiated. Since it was not communicable it was forbidden to explain the divine secret to any one to whom it had not been vouchsafed to see it of himself. Now since in the vision there were not two, but the seer was made one with the seen, not as with something seen, but as with something made one with himself, he who had been united with it might, if he remembered, have by him some faint image of the divine. He himself was one, with no distinctions within himself either as regarded himself or outer things. There was no movement of any sort in him, nor was emotion or desire of 
any outer thing present in him after his ascent, no, not any reason or any thought, nor was he himself present to himself, if I may so express it; but as rapt and inspired he rested isolated in his unmoved and untroubled essence, inclining nowhere and not even reflecting upon himself, at rest in all respects, yea, as if he had become rest itself. Nor did he concern himself with the beautiful, but had passed beyond beauty and had transcended the series of virtues as one might penetrate into the interior of the holy of holies, leaving behind in the temple the statues of the gods. And these he would not see again till he came out after having had the vision of what lay within and communion there with what was no statue or image but the divine itself-of which the statues were but secondary images. And perhaps his experience was not a vision but some other kind of seeing, ecstasy and simplification and self-surrender, a yearning to touch and a rest and a thought centred upon being merged in the divine. Perhaps this was his experience if he beheld anything in the holy of holies. Did he look elsewhere, there was nothing there.

These are mere figures and only hint to the wise among the prophets of the manner in which that God of whom we spoke is beheld. But the wise priest who reads the riddle aright may when he has entered the sanctuary enjoy the vision there; and even if he has not entered, yet because he has believed the sanctuary to be something invisible and has regarded it as a fountain and a source, he will yet know it as the source of all things, and behold it as such, and be merged with it, by like perceiving like, and will miss no divine thing which the soul is capable of attaining. And before the vision comes, he begs for the remnant and remainder of the vision. But 
for him who has transcended all things there remains that which is prior to all things.

All that I have said is true, for the nature of the soul never reaches absolute non-existence, but in her descent reaches evil, and in this sense non-existence, but not complete non-existence. And in pursuing the opposite course she reaches no outer object, but herself, and hence she does not dwell in nothing because she is in no outer object, but in herself. But to be in herself and not in existence is to be in God. For a man himself becomes not an essence, but superessential in so far as he clings fast to God. When now he sees that he has transcended essence he is himself an image of God. And when he proceeds out of himself turning from a copy into the original he has reached the goal of his journey. Does he at time fall from the vision, then virtue is aroused within him, and beholding himself adorned in every way, he is again lifted up by the help of virtue to the intelligible world, and thence proceeds through the aid of wisdom back to God. So it is that the life of the gods and of godlike and blessed men is a liberation from the things of earth, a life that takes no joy in them, a flight of the soul isolated from all that exists to the isolation of God. 



\section{INDEX OF NAMES}

Alemæon, 37.

Anaxagoras, 4, 48, 49, 97, 118, Lucretius, 305-316. $229,244$.

Anaximander, 3.

Anaximenes, 7.

Antipater of Tarsus, 272.

Antipho, 95.

Antisthenes, 145.

Apollodorus, 272, 276.

Archedemus, 274.

Aristippus, 91, 142.

Aristotle, 4, 86, 217-268.

Boethius, 272.

Chrysippus, 269, 271, 272, 274, $275,276,277,278$.

Cleanthes, 269, 273, 274, 276, 27\%.

Democritus, 48, 58, 59, 315 .

Diogenes, 143, 147, 274.

Empedocles, 43, 48, 229, 247.

Epictetlis, 317, 330.

Epicurus, 143, 144, 281, 290305, 315, 329.

Euthydemus, 94.

Evenus, 108.

Gorgias, 67, 85, 108.

Hecatæus, 30.

Hecaton, 273.

Heraclitus, 28-35.

Hippias, 74, 75, 108.
Leucippus, 57, 65, 228, 229.

Marcus Aurelius, 326-339.

Melissus, 21.

Meno, 85, 101.

Parmenides, 11, 21, 57, 170 et seq.

Persaus, 275.

Phadrus, 149.

Plato, 129, 135, 148-216, 228, $229,368,377,383,384,386$, 389.

Plotinus, 340-393.

Plutarch, 278.

Posidonius, 273.

Prodicus, 74, 76, 108.

Protagoras, 67, 68, 78.

Pythagoras, 30, 35, 36, 149, 284,362 .

Socrates, 1, 86-141, 284, 317, $322,323,324,356,362,363$.

Speusippus, 284.

Thales, 1.

Theatetus, 78.

Theognis, 267.

Timaus, 160.

Xenocrates, 284.

Xenophanes, 8, 20, 21, 30, 57.

Xenophon, 86.

Zeno of Citium, 269, 273, 275, $284,322$.

Zeno of Elea, 22, 168. 



Bakevell

Source book in ancient philosophy
B

108

. $\mathrm{B} 18$.

$$
\text { A. Y } Y 5504
$$


(1) to i. 